UNITED STATES DEPARTMENT OF THE INTERIOR

J. A. Krug, Secretary

GEOLOGICAL SURVEY

W. E. Wrather, Director

Water-Supply Paper 943

\title{
GEOLOGY AND GROUND-WATER RESOURCES OF SCOTTS BLUFF COUNTY, NEBRASKA
}

BY

L. K. WENZEL, R. C. CADY AND H. A. WAITE

Prepared in cooperation with the

CONSERVATION AND SURVEY DIVISION OF THE UNIVERSITY OF NEBRASKA

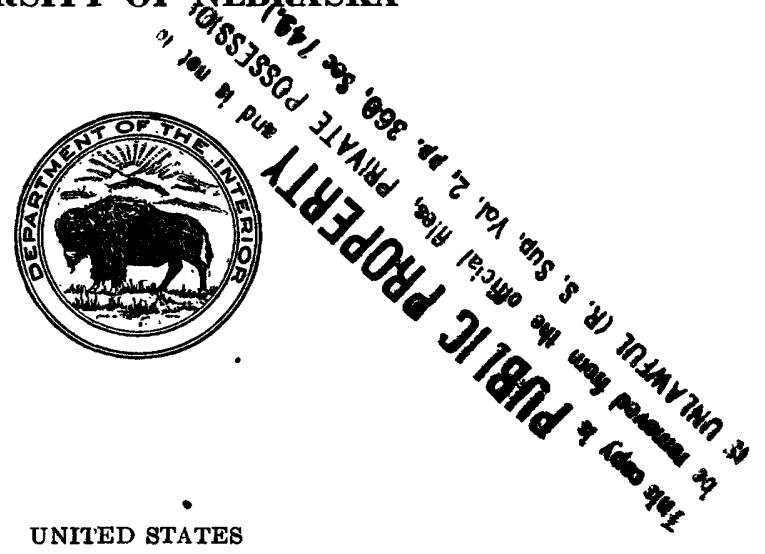

GOVERNMENT PRINTING OFFICE

WASHINGTON : 1946

For sale by the Superintondent of Documents, U. B. Government Printing Office, Wachington 25, D. C. Price 25 cents 



\section{CONTENTS}

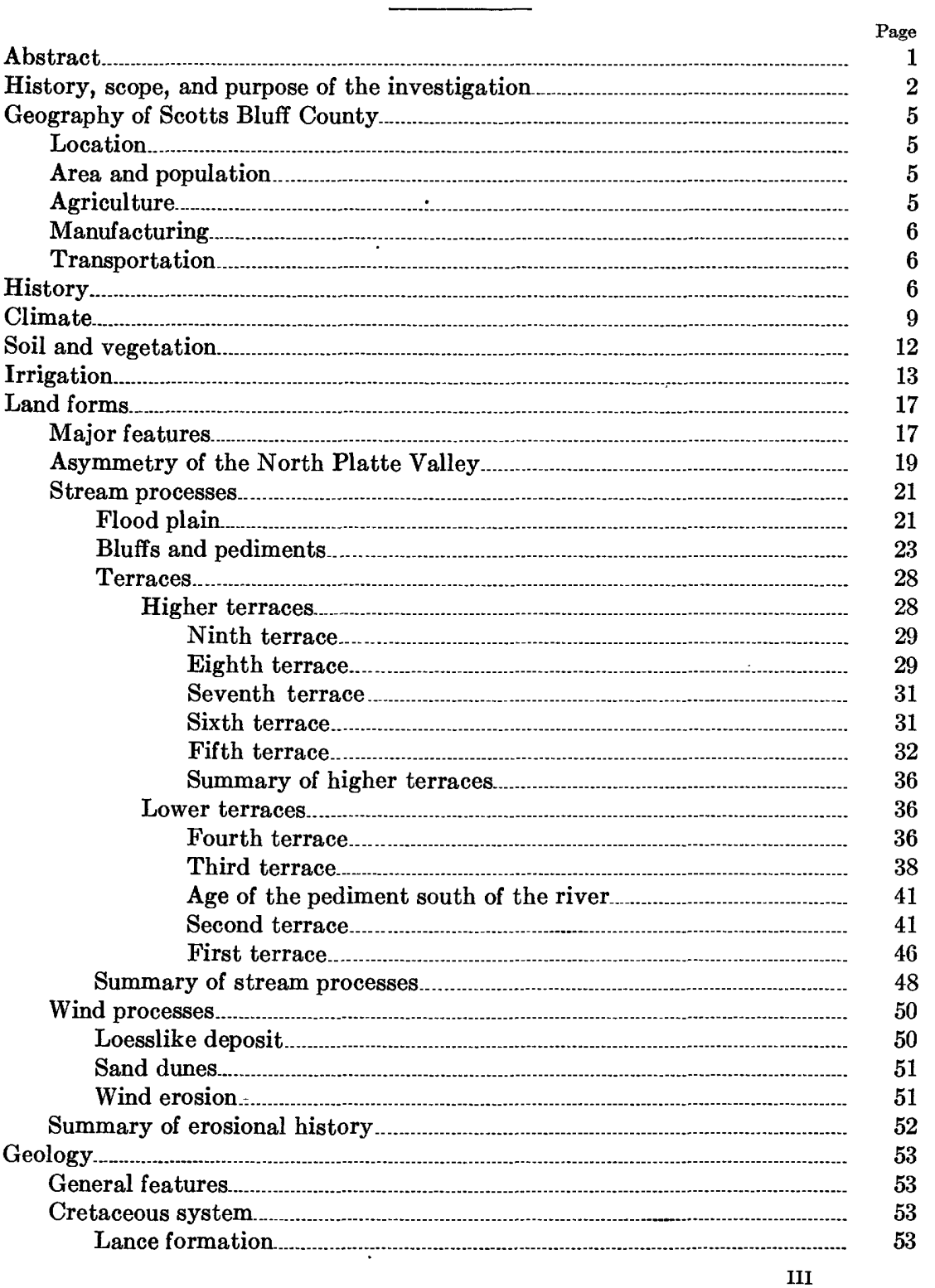


Tertiary system

White River group

Chadron formation

Brule formation

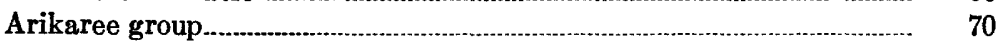

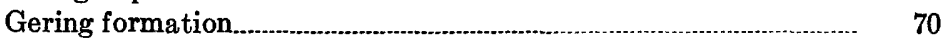

Upper sandstones of the Arikaree group

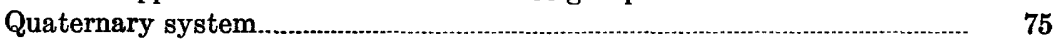

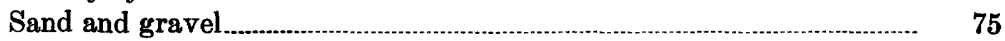

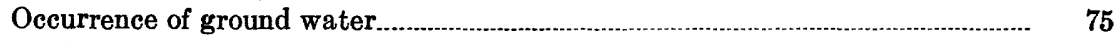

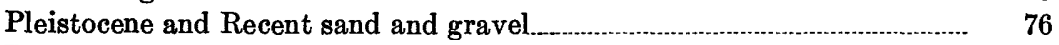

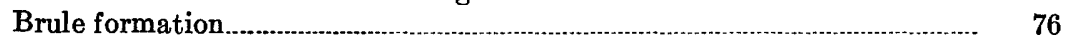

Lance formation.

Hydrologic properties of the water-bearing formations

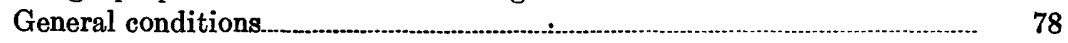

Pleistocene and Recent sand and gravel

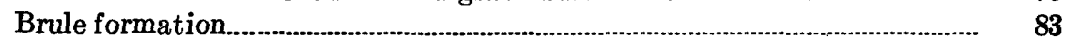

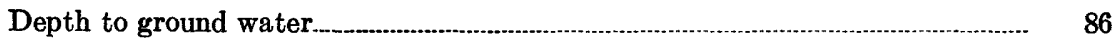

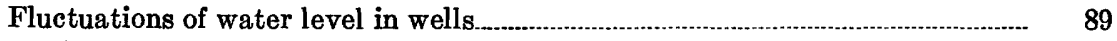

Method of investigation._._._. $\quad 89$

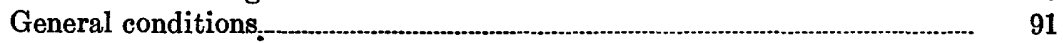

Fluctuations caused by seepage from irrigation ditches and irrigated fields.

Fluctuations caused by changes of water stored in Lake Minatare............. 96

Fluctuations caused by precipitation...................................................... 97

Fluctuations caused by changes in flow of the North Platte River........... $\quad 98$

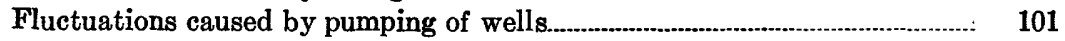

Fluctuations caused by changes in atmospheric pressure........................ 103

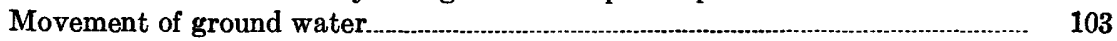

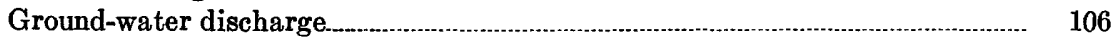

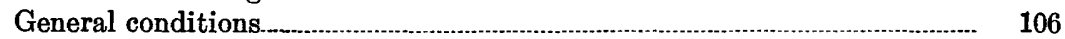

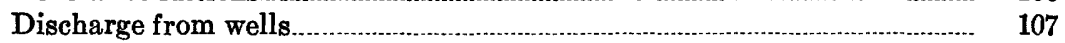

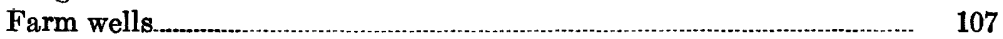

Irrigation wells

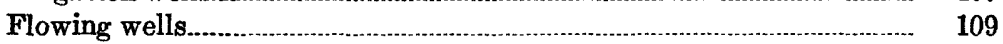

Industrial wells

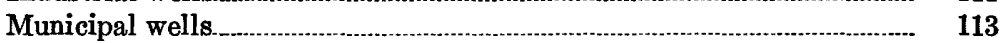

Evapo-transpiration ..............._. 116

Springs____

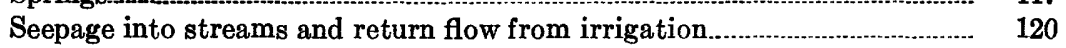

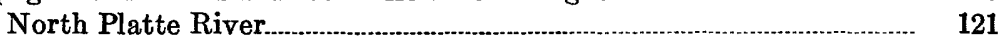

Tributaries of the North Platte River

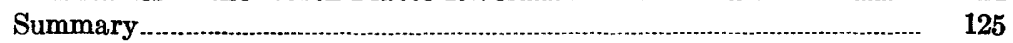

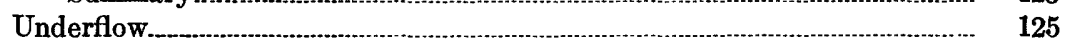

$\begin{array}{ll}\text { Estimate of annual discharge. } & 126\end{array}$

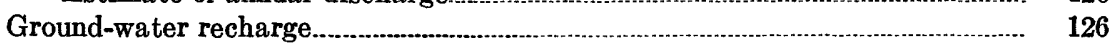

Chemical character of the ground water

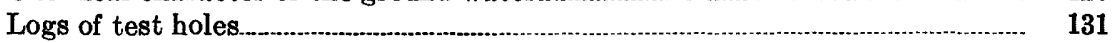

Well records

Index $\ldots$ 


\section{ILLUSTRATIONS}

Plate 1. Topographic map of Scotts Bluff County, Nebr., and adjoining areas showing location of gravel-filled channels by means of contours on the top of Brule and Chadron formations. In pocket

2. Geologic map of Scotts Bluff County, showing distribution of Cretaceous and Tertiary sediments and location of test holes.. In pocket

3. Map of Scotts Bluff County, showing location of domestic, farm, irrigation, flowing, and observation wells, contour lines on the water table, and approximate location of main irrigation canals and larger streams tributary to the North Platte River....... In pocket

4. North-south profiles across Scotts Bluff County showing geology,

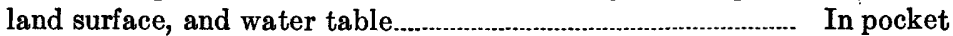

5. East-west profiles across Scotts Bluff County showing geology,

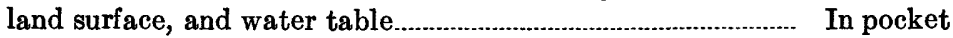

6. Hydrographs showing fluctuations of water level in wells in eastern Scotts Bluff County. In pocket

7. Hydrographs showing fluctuations of water level in wells in eastern Scotts Bluff County. In pocket

8. Hydrographs showing fluctuations of water level in wells in central Scotts Bluff County. In pocket

9. Hydrographs showing fluctuations of water level in wells in western Scotts Bluff County. In pocket

10. Graphs showing fluctuations of water levels in 9 wells in Scotts Bluff County, and precipitation near Mitchell, 1934-40.......... In pocket

11. Graphs showing relation of discharge of irrigation canals and fluctuations of Lake Minatare to fluctuations of water level in observation wells. In pocket

12. Analysis of water regimen of North Platte River between WyomingNebraska State line and Minatare, Nebr. In pocket

Figure 1. Index map of Nebraska showing areas covered in ground-water investigations since 1930 by the U. S. Geological Survey in cooperation with ${ }^{\circ}$ the Conservation and Survey Division, University of Nebraska.

2. Map of Scotts Bluff County and southwestern Sioux County, showing main irrigation canals and laterals.

3. Topographic profile across Pumpkin Creek and North Platte Valleys, with a profile across the inner valley of the Niobrara River.

4. Six topographic profiles up the north wall of the North Platte Valley showing terrace surfaces and their height above the river.

5. Map showing fifth terrace surface in Scotts Bluff County and adjacent areas by means of lines connecting points lying at equal height above the level of the North Platte River. 
Figure 6. Profiles along valley of North Platte River in Scotts Bluff, Sioux, and Morrill Counties, showing downstream gradient of the river and of the ninth, eighth, seventh, and sixth terrace surfaces, compared with the slope of the contact between the Brule formation and the sandstones of the Arikaree group.

7. Ideal cross section of a tributary valley south of the North Platte River showing the relation of first and second terraces to surface of the rock-cut slope.

8. Graph from automatic water-stage recorder showing rise of water level in well 136 caused by precipitation.

9. Graphs showing relation between fluctuations in discharge of the North Platte River at Mitchell and fluctuations of water level in well 222

10. Graph from automatic water-stage recorder showing fluctuations of water level in well 303 caused by pumping well 305 Graph from automatic water-stage recorder showing fluctuations of water level in well 201 caused by changes in atmospheric pressure

12. Areas of heavy ground-water discharge by evapo-transpiration......

13. Discharge of Gering drain for first 3 months of each year from 1923 to 1938 .

14. Rating curve showing relation between average water levels in observation wells and discharge of small streams. 


\title{
GEOLOGY AND GROUND-WATER RESOURCES OF SCOTTS BLUFF COUNTY, NEBRASKA
}

\author{
By L. K. Wenzel, R. C. Cady, and H. A. Waite
}

\section{ABSTRACT}

Scotts Bluff County in westernmost Nebraska, adjoining the State of Wyoming, is occupied by the valley of the North Platte River and adjacent uplands. It contains one of the oldest irrigation projects in the State. In 1930, 90 percent of its farms, making up 51 percent of the acreage in the county, were irrigated, mostly with water from the river, and in that year 46.5 percent of the irrigated area in the State of Nebraska was in Scotts Bluff County.

This county is underlain by Cretaceous and Tertiary formations and alluvial deposits of Quaternary age. The oldest exposed formation is the Lance, of Cretaceous age. It is overlain successively by the Chadron and Brule formations, of Oligocene age. The Gering sandstone and younger sandstones of the Arikaree group of Miocene age are exposed on the upper slopes of the North Platte Valley and on the uplands.

The topography of the area is significant, because of its magnificent scenic qualities, its intricate and partially revealed geomorphic history, the control it exerts on the hydrology, and because some rather unusual geomorphic processes have served to create it. On the north walls of the valley, where protective coverings of gravel have been deposited, nine terrace surfaces have been identified in a vertical interval of about 1,000 feet. Of these, the four highest are gravel-capped benches, presumably of early to middle Pleistocene age. They are separated from the lower terraces by a steep surface called the fifth terrace, now preserved as a dissected slope. The slope represents a stage of great deepening of the North Platte Valley. Four terraces may be identified in the inner valley at lower elevations. The third from the bottom is of great importance in the study of the groundwater hydrology, for during its later development channels were cut into it to a depth of as much as 200 feet below the present flood plain. The channels were soon filled with sand and gravel, and they now constitute a most productive and intensively used source of ground-water supply. The two terraces below this are of importance because they contain cultural remains; the second contains dart points of the Yuma type, and the lowest contains more recent cultural remains. The two lower terraces have, it is believed, been fitted into a late glacial and postglacial chronology.

Ground water occurs chiefly in Pleistocene and Recent sand and gravel and in the Brule and Lance formations. The most productive wells, which include almost all that are pumped for irrigation, industrial, and municipal supply, draw water from the Pleistocene and Recent sand and gravel beneath the inner valley of the North Platte River or beneath the third terrace north of the river. Many of these wells yield as much as 1,000 gallons of water a minute. Most farm wells of the area derive small but adequate supplies of water from cracks and crevices in the Brule formation, which is the most widespread water-bearing formation that occurs near the surface. A few wells in the western part of the county tap water under artesian pressure in the Lance formation and obtain flows ranging from a trickle to slightly more than a gallon a minute. The water from the Pleistocene and Recent sand and gravel and that from the Brule formation is of good chemical quality and is suitable for most purposes; water from the Lance formation is rather highly mineralized.

The seepage of water diverted from the North Platte River for irrigation has raised the water table in Scotts Bluff County and has greatly increased the flow of tributaries to the river. The water table at some places is probably now 50 feet, or more, higher than it was before irrigation was practiced. Return flow from 
irrigation is believed to be several hundred thousand acre-feet of water a year.

The depth to ground water ranges from less than 1 foot to as much as 275 feet. The ground water beneath most of the county, however, occurs at comparatively shallow depths; in only 13 out of about 340 wells visited during the investigation was the water level more than 100 feet below the surface. The movement of ground water is in general toward the North Platte River, although locally it is toward tributaries of the river, drainage ditches, or areas of shallow water table where discharge through evaporation and plant growth is large. In the extreme southwestern part of the county the ground water moves southward toward Pumpkin Creek in Banner County. Rather large seasonal fluctuations of water level, caused chiefly by seepage from irrigation canals and irrigated flelds, occur in wells in the area. The average of the water levels in 20 observation wells, on which periodic observations were made from July 1937 to August 1938, had a maximum fluctuation of about 6 feet. Seasonal fluctuations of water levels of more than 20 feet were observed in several wells.

Ground water is discharged from Scotts Bluff County by wells, plants, evaporation, springs, streams, and underflow. Discharge by wells, which includes pumpage and flow for farm, domestic, irrigation, industrial, and municipal purposes, is estimated to be about 8,000 acre-feet of water a year (an average of about 7,300,000 gallons a day). This compares with estimates of 100,000 acre-feet of ground water discharged from the zone of saturation by evaporation and transpiration and 325,000 acre-feet of ground water-mostly return flow from irrigation-discharged from streams. The total discharge of ground water from the county is estimated to be about 437,000 acre-feet a year. Recharge of ground water occurs chiefly from seepage of irrigation water, precipitation, and underflow. By far the largest amount of recharge is supplied by seepage from canals and irrigated fields. The quantity of water added each year to the underground reservoirs is believed to equal approximately the quantity of water that is discharged annually from them.

\section{HISTORY, SCOPE, AND PURPOSE OF THE INVESTIGATION}

The investigation of the geology and ground-water resources of Scotts Bluff County was undertaken in pursuance of a cooperative program that has been carried on continuously since 1930 by the Geological Survey, United States Department of the Interior, and the Conservation and Survey Division, University of Nebraska. It is the third of a series of detailed areal studies to be made by the two agencies, the first having included the south-central part of the State with special reference to the Platte Valley, and the second having included Keith County. ${ }^{1}$ (See fig. 1.)

Special hydrologic problems arising from these studies have been given special attention, and some have been published separately. ${ }^{2}$ In addition to the collection and interpretation of data relating to these studies several hundred observation wells were located and equipped in 1934, and their water levels have been measured at intervals since. The records have been tabulated and published in the series of annual water-supply papers dealing with water levels and artesian head in observation wells in the United States. ${ }^{3}$

The field work on the present investigation was begun in July 1937 and was continued until mid-December of the same year. Weekly measurements of the water levels in observation wells, however, were continued throughout the winter and spring and early in the summer of

\footnotetext{
1 Lugn, A. L., and Wenzel, L. K., Geology and ground-water resources of south-central Nebraska: U. S. Geol. Survey Water-Supply Paper'779, pp. 1-242, 1938. Wenzel, L. K., and Waite, H. A., Ground-water resources of Keith County, Nebr.: U.S. Geol. Survey Water-Supply Paper 848, pp. 1-68, 1941.

2 Wenzel, L. K., The Thiem method for determining permeability of water-bearing materials, and its application to the determination of specific yield: U. S. Geol. Survey, Water-Supply Paper 679-A, pp. 1-57, 1936; Local overdevelopment of ground-water supplies with special reference to conditions at Grand Island, Nebr.: U. S. Geol. Survey Water-Supply Paper 836-E, pp. 233-281, 1940.

Wenzel, L. K., Methods of determining permeability of water-bearing materials: U. S. Geol. Survey Water-Supply Paper 887, pp. 1-192, 1942. U. S. Geol. Survey Water-Supply Papers 777, 817, 840, 845, 886, 908,938 , and 946 .
} 


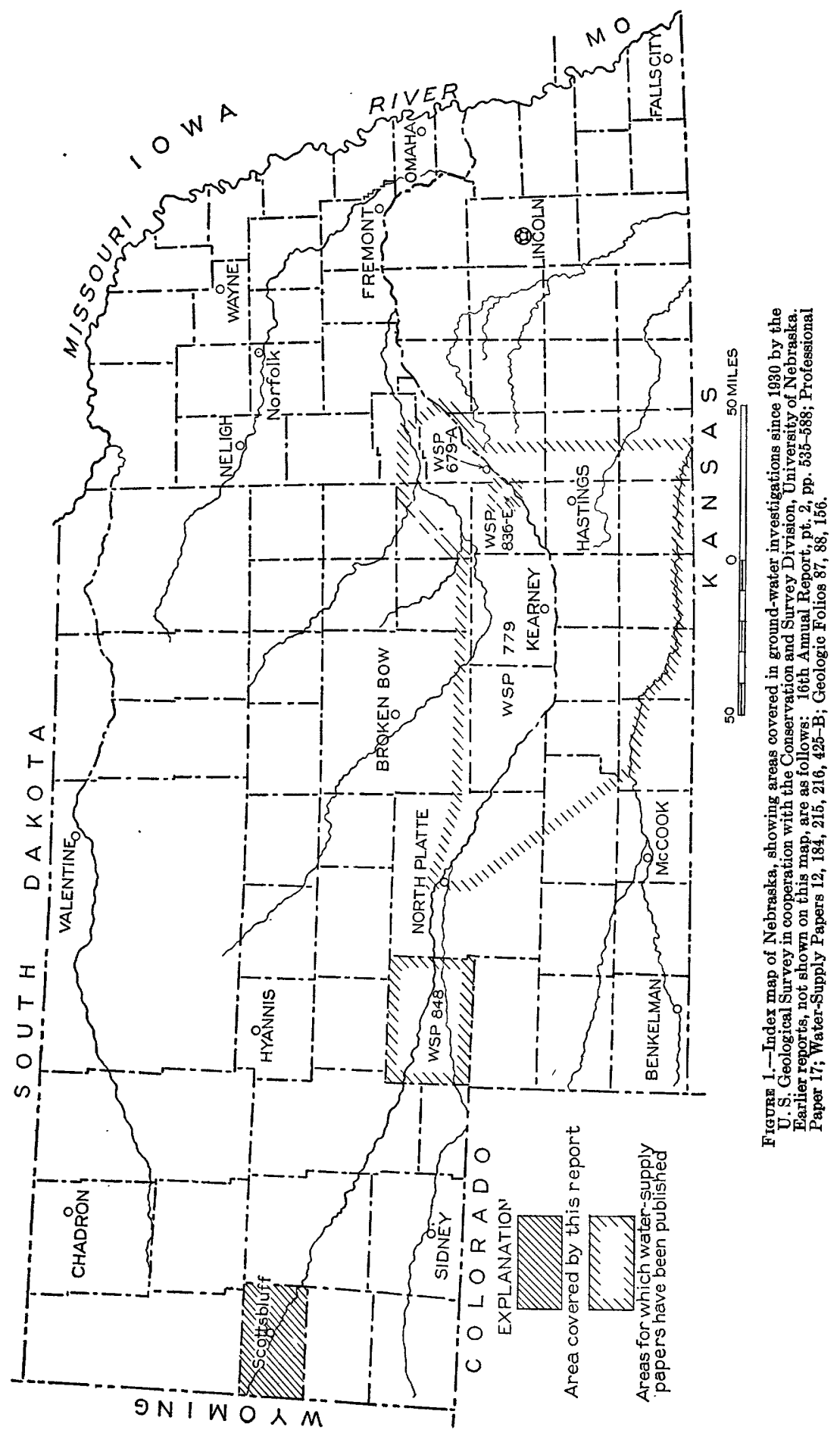


1938. The investigation was carried out under the general supervision of O. E. Meinzer, geologist in charge, Division of Ground Water of the Federal Geological Survey, and G. E. Condra, director of the Conservation and Survey Division, University of Nebraska. L. K. Wenzel, of the Federal Geological Survey, was assigned active direction of the project; R. C. Cady, of that organization, was responsible for the geologic studies; and H. A. Waite, of the Nebraska State Geological Survey, was responsible for the collection of hydrologic data. Howard Haworth and Robert Lawrence, and, for a short period, Oliver Scherer, of the State survey, manned the drilling rig furnished by the State and carried out the program of test-hole drilling. E. L. Marlin, a temporary employee, measured the observation wells after the termination of the field season. Margaret D. Foster, chemist in the Quality of Water Division of the Federal Geological Survey, made chemical analyses of samples of ground water and surface water in Scotts Bluff County.

The parts of this report that deal with the history, scope, and purpose of the investigation, geography (except for the section on irrigation), land forms, and geology, were written by Mr. Cady; the remainder was written by Mr. Wenzel with the collaboration of Mr. Waite, who prepared the map showing location of wells and contours on the water table and made many tabulations, including those of well records.

Ground water in a subhumid to semiarid State like Nebraska is a valuable natural resource, lying stored in great porous reservoirs where the soil and bedrock and topography permit, spilling into rivers and streams and sustaining their flow, and furnishing water to wells and springs for domestic, stock, municipal, industrial, and irrigation supplies. Some of the rain that soaks into the soil ultimately reaches the zone of saturation and replenishes the supply of ground water. Streams also replenish it. The purpose of the present investigation, as of the others carried on previously, is to discover as fully as possible the location and distribution of the ground water in the area chosen for study; where it can be recovered in large quantities at economically low costs; where land owners must be content with small supplies; how much and at what rate water can be taken from the water-bearing formations without exhausting the supply; where the ground water comes from, and where it is going; in what localities and under what conditions recharge and natural discharge occur; the uses to which ground water is put, and how much is used; at what depth below the land surface it lies; the distribution of water-bearing materials beneath the surface of the land, and their capacity for storage and yield; the chemical character of the ground water; and many other pertinent facts. The purpose is not only to answer questions, however, but also to accumulate data that will make possible the answering of special questions as they arise in the future.

In Scotts Bluff County the practice of irrigation by means of surface water brought to the land from the North Platte River has introduced the additional problem of return flow from the irrigated fields and from leaking canals and reservoirs. This flow represents the water that has escaped the roots of the crops and native vegetation, has reached the zone of saturation, and has percolated back into the river, where it becomes available to water users farther downstream. During its transit from field or canal to river, or to another point of discharge, the return flow is by definition ground water and is subject to quantitative study in this investigation. 
The writers take this opportunity to acknowledge their indebtedness to O. E. Meinzer and G. E. Condra for their advice and counsel in planning and executing the investigation and preparing the report for publication. For specific cooperation in matters concerning the investigation thanks are due R. H. Willis, chief, Bureau of Irrigation, Water Power, and Drainage, of the State of Nebraska; T. W. Parry, manager, Pathfinder Irrigation District; E. C. Reed, assistant State geologist of Nebraska; Kirk Bryan, professor of geology at Harvard University; and A. L. Lugn, professor of geology, University of Nebraska. The writers a]so acknowledge their indebtedness to the well owners, city officials, and owners and managers of industrial establishments, for having furnished information regarding the wells on their properties, and for having permitted access for the purpose of gathering essential information.

\section{GEOGRAPHY OF SCOTTS BLUFF COUNTY}

Location.-Scotts Bluff County is situated at the west-central extremity of the panhandle of Nebraska, where the North Platte River enters the State. It is bounded on the north by Sioux County, on the east by Morrill County, on the south by Banner County, and on the west by the State of Wyoming. It is a little nearer the southern boundary of the State than the northern. The city of Scottsbluff is about 420 miles west of Lincoln, the capital of the State.

Area and population.- Scotts Bluff County is oblong in shape, having an east-west dimension of about 36 miles and a north-south dimension of about 20 miles. Its area is 723 square miles. In 1940 the total population of the county was 33,917, a gain of about 5,000 during the decade since 1930. The density of population, 46.9 persons for each square mile of area, is one of the highest in the State. Nine communities are strung along the river, four of which have populations of more than one thousand, as listed below:

\begin{tabular}{|c|c|}
\hline \multirow{2}{*}{\multicolumn{2}{|c|}{$\begin{array}{lr}\text { Gering (the county seat) } & \text { Population } \\
& 3,104\end{array}$}} \\
\hline & \\
\hline & \\
\hline Grew...-1- & \\
\hline & \\
\hline re. & 1,125 \\
\hline 1 & \\
\hline luff & 12,0 \\
\hline
\end{tabular}

The 20,476 persons inhabiting these communities constitute a little more than 60 percent of the population of the entire county. The rest live on the numerous farms.

Agriculture.-In 1940 there were 1,900 farm units in this county, embracing essentially all the land, about half of which was harvested that year. Most of the units are irrigated farms, dry farms, or livestock ranches. Of the total, however, about half are "crop specialty" farms of from 50 to 259 acres. On these are raised sugar beets, potatoes, hay, alfalfa, beans, soy beans, and grain. About one-third of these cropspecialty units are operated by the owners, and two-thirds by tenants on a cash-rental or crop-sharing basis, or a combination of the two. Above the highest irrigation ditches the lands are less intensively utilized, but dry farming or cattle ranching are practiced. For the county as a whole the chief crops are sugar beets, potatoes, and feed crops, including alfalfa, 
hay, corn, and other grains. Cattle for beef comprise most of the livestock, but some dairy cattle and hogs are raised.

Marketing is effected through Scottsbluff, Gering, Mitchell, and the smaller communities, all of which are on improved highways and a railroad.

Manufacturing.-Manufacturing and industry relate chiefly to products of the soil, and the establishments in Scotts Bluff County are mostly engaged in extracting sugar from sugar beets, in meat packing and rendering, and in storage of grain and other farm products. The Great Western Sugar Co. operates factories in Lyman, Mitchell, Scottsbluff, and Minatare. The relation of these manufacturing establishments to the use of ground water is discussed on page 111.

Transportation.-Transportation facilities in Scotts Bluff County, in keeping with the high degree of its agricultural and industrial development, are excellent. The Casper branch of the Chicago, Burlington, and Quincy R. R., following the north bank of the North Platte River, crosses the county and connects it with the West and markets of the East. Similarly a branch of the Union Pacific R. R. parallels the south bank, connecting directly with its main branch at North Platte. Both railroads run numerous spurs to the beet dumps that are scattered throughout the county. U.S. Highway 26, a hard-surfaced road, parallels the river on the north side; and State Highway 86, a graveled road, crosses the county from east to west on the south side of the river. State Highway 29 enters the county from the north, connects with the east-west road at Mitchell and continues southward to Harrisburg and Kimball from Scottsbluff and Gering. State Highway 87, a graveled road strikes northward from Scottsbluff to shorten the route toward the northeast. Within the irrigated parts of the county the section roads which have been improved by widening and graveling make the markets and shipping facilities of the towns easily accessible to most of the population. A scenic road has been completed by the National Park Service to the summit of Scotts Bluff Monument. Great numbers of people visit the summit and the museum at the base of the monument each year.

\section{HISTORY}

The history of Scotts Bluff County embraces the four chief stages in the settling of the West. The North Platte Valley afforded an easy route for the early explorers and trappers, the wagon trains of the emigrants passing westward, the cattlemen, and later the homesteaders.

This outline of the history of Scotts Bluff County is based chiefly upon records accumulated by Merrill J. Mattes, historian and custodian, Scotts Bluff National Monument, and upon information set forth in "The Oregon Trail," a Federal Writers Project of the Works Progress Administration, published by Hastings House, New York, 1939.

The earliest known inhabitants of the county were those prehistoric hunters who left flint dart points of the Yuma type as their only trace. They hunted a species of bison that had become extinct by historic times. At present there is no general agreement as to the antiquity of these peoples, but they may have occupied western Nebraska during a moist period that ended 8,000 to 10,000 years ago, or even at an earlier time during the last stage of the Pleistocene or "Glacial" epoch. They were followed some time later by another hunting, nonagricultural people, 
who did not use arrows or make pottery. Their implements have been found in the lower and middle culture zones at Signal Butte. Next came proto-Pawnee people of the Upper Republican culture, who practiced agriculture, made pottery, and constructed semisubterranean lodges. After these came the sedentary tribes of the true Pawnee Indians, who established farming villages of earthen huts in the valley and hunted on the plains. The earliest white men in the Platte and Loup valleys found them living thus. About 1760, Indians of the Sioux, or Dacotah, tribes, who then gardened and hunted in the forests west and south of Lake Superior, were defeated by the Chippewa Indians, who had obtained guns from French traders. Gradually the Dacotahs moved out into the plains, discarded their old arts and ways of life, acquired horses and assumed the culture of the Plains Indians, based on the horse, the buffalo, the arrow, and later the gun. The Brule and Ogallala bands of the Teton Dacotahs with their allies, entered into a merciless warfare against the established tribes of the Pawnees and drove them eastward out of the North Platte Valley.

In 1759 the brothers Mallet and six other Frenchmen from Canada found a wide, shallow river, and translating an Oto Indian name for it, "Nibrathka," into their own language, they called it the Platte. The Wilson Price Hunt party was the first group of white men to pass overland through the North Platte Valley toward the west. They made the journey in 1811-12 and opened the way for the trappers, who for the next 30 years traversed it as the best route between the towns on the Missouri and Mississippi Rivers and the trapping lands of the Oregon country. About 1828 Capt. Hiram Scott fell sick while journeying eastward, probably near the junction of the North Platte with the Laramie River. Abandoned by his companions he crawled to a spring at the south foot of Scotts Bluff and there died. Those who found his skeleton named the bluffs after him. The history of the Oregon Trail as a wagon route began in 1830, when a party of trappers under the leadership of William Sublette set out for the Oregon country with 80 men astride saddle mules, 10 wagons each drawn by 5 mules, 2 dearborns with 1 mule each, and 12 head of cattle including 1 milk cow. In 1832 Captain Bonneville, acting under secret orders from Washington, led a wagon train to Oregon.

Complex motives and pressures-economic, romantic, political, imperialistic, and perhaps racial-sent emigrants pouring across the plains, often called the Great American Desert, laden with seed, powder, tools, food, and heirlooms, to Oregon and California. The Oregon Trail passed through Scotts Bluff County. Their wagons followed the lower slopes and floodplain of the North Platte River on the south side, crossed the Scotts Bluff salient of Wildcat Ridge at Roubadeau Pass, and returned to the river near the mouth of Horse Creek. The trail had a complex system of feeders, but most of the emigrants started from Independence, Mo., went northwestward into Nebraska, thence followed along the south bank of the Platte past Grand Island and North Platte, crossed the South Platte at the Lower California crossing, west of Brule, in Keith County, or at the Upper California crossing, just west of Lodgepole Creek. Here they parted company with those who were taking the Overland Trail, and took the branch of the Oregon Trail that entered the North Platte Valley near Courthouse Rock and led to Fort Laramie beyond. 
In 1847 , when about 4,500 other emigrants journeyed to Oregon and about 1,000 to California, the first party of Mormons set out for Utah under the leadership of Brigham Young. Leaving their winter quarters in Council Bluffs, Iowa, on April 7, 143 persons, including 3 women and 2 children, followed the north bank of the Platte, and 3 months and 17 days later passed Scotts Bluff. Other parties left the same year, bringing the total number of Mormon emigrants in 1847 to 1,553 persons. In 1849, after gold had been found in California, more than 25,000 people went over the Oregon Trail to California, and 400 to Oregon.

At this time several trails split off at Fort Kearney, followed the South Platte and rejoined the main trail at Fort Laramie. In 1848 or 1849, Basil Roubadeau built a smithy where, for a substantial consideration, the emigrants were permitted to work at the forge, shoeing their horses and repairing wagons. In 1852, Arapaho or Kiowa Indians destroyed the post, and about the same time soldiers from Fort Laramie cut a passable trail through the shorter route by Mitchell Pass. Roubadeau moved his trading post to Carter Canyon, not far from a similar post established by the American Fur Co. in Helvas Canyon. Emigrants used both passes, for whereas the Mitchell Pass route was shorter, it provided an excellent ambush for hostile Indians. Until the early 60's the great wagon trains bore their burdens over the Oregon Trail in what has been termed the greatest folk migration in all history. More than $3,000,000$ human beings are said to have traversed the Oregon Trail. The trail can still be seen in the two passes, eroded by water and drifted with sand.

The Pony Express was operated from April 3, 1860, to October 24, 1861, when the transcontinental telegraph line was completed. In 1863 and 1864, Fort Mitchell, 21/2 miles northwest of Mitchell Pass, guarded the emigrants passing through the narrow part of the trail back of Scotts Bluff, but from 1862 to 1865 the Indians, still numerous, desperate, and hungry, made the old trail so unsafe that most of the traffic was routed through the South Platte Valley. In June 1865 a battle took place at Horse Creek between 135 soldiers and 1,500 Indians, whom they were escorting from Fort Laramie to Fort Kearney. The trouble with the Indians was doubtless one reason for building the Union Pacific Railroad through the South Platte and Lodgepole Valleys, from 1865 to 1869, instead of through the North Platte, as originally planned.

By 1870 a few people had come to regard the country about Scotts Bluff County as a place in which to make a home. Already "road ranches" had grown up along the trail, where fodder could be bought and trail-worn cattle traded for fresh ones. By 1871, cattle ranches had been established on Horse Creek, and 12,800 head of cattle had been turned loose there; in that year 45,000 more were pastured on the open range. There was great expansion from 1876 to 1881 . The country was overstocked, however, and barbed wire fences were being erected as early as 1874-77. Homesteaders began to arrive about 1885 . Since then ranching has become more scientific, and the grazing lands are now generally fenced.

In 1872 sugar beets had been raised experimentally, and in 1888 several farmers near Grand Island harvested a successful crop of them. In 1888 the first large canals were constructed to bring water from the North Platte River to the lands along its margin. More than any other single factor, the raising of sugar beets by irrigation brought prosperity to 
Scotts Bluff County. By 1890 twelve irrigation companies had been organized in the North Platte Valley and by 1895 there were 118 miles of canal in Scotts Bluff County. But the years 1890 to 1895 were disastrously dry. In the summer of 1890 , hot winds did great damage. Consequently about three-fourths of the settlers left the region.

\section{CLIMATE}

Western Nebraska is characterized by a climate of the continental type. The weather is variable from year to year, but usually the summers are very hot and the winters are very cold. The precipitation reaches a maximum in spring or early in summer and dwindles to very small amounts in the winter when it usually takes the form of light dry snow. The summer rains come largely in local thunderstorms. During the passage of the feeble summer cyclonic disturbances these storms are often numerous, so that several may be visible at one time. Many of them remain small, and the rain curtain hanging darkly from the clouds may never reach the earth. On occasions, however, they become violent, and rainfall of high intensity may occur. Sometimes hail, lightning, high winds, and flood may work considerable destruction to man-made structures, crops, and even to human life. Rarely, tornadoes accompany such storms in summer. Rainfall coming in such local showers is likely to be unevenly distributed over a county, and as shown in table 4 , the four rainfall stations record quite different monthly amounts of precipitation. Even the normal precipitation differs among the stations. The rainfall is variable from year to year, and extremely dry periods like those that prevailed from 1890 to 1895 and from 1930 to 1937 cause repeated crop failures, except where the land is irrigated. In summer, during the day the wind generally blows steadily from the southwest, but during the night it diminishes. Cyclonic winds occasionally prevail, however, and for a few days the diurnal variation of wind velocity may be suspended. In fall and winter and early in spring the wind blows more steadily, prevailing from the west and northwest. In the cold seasons, when the cyclonic circulation of the prevailing westerlies is more vigorous, cold anticyclonic winds from the northwest are likely to raise much dust from cultivated fields and dirt roads, and soil is drifted to the fences at the southern and eastern sides of some fields. The prevalence of strong dry winds makes for rapid evaporation; the Weather Bureau records show that during the warm season as much as 5 to 10 inches of water evaporates from experimental evaporation pans in a month.

The growing season is about 5 months. At Scottsbluff the last killing frost in spring and the first killing frost in fall came, respectively, on April 29 and September 24 in 1937, and on May 9 and October 18 in 1938; at Lake Minatare, on April 30 and September 25 in 1937, and on May 9 and October 8 in 1938; in Mitchell, on May 13 and September 24 in 1937, and on May 8 and October 18 in 1938.

The accompanying tables show the normal monthly and annual air temperature, and the monthly and annual air temperature for 1937 and 1938; the normal monthly and annual precipitation, and the monthly and annual precipitation for 1937 and 1938, at all stations in Scotts Bluff County. The annual rainfall recorded at Scottsbluff from 1889 to 1938 is given in another table on page 12 . 

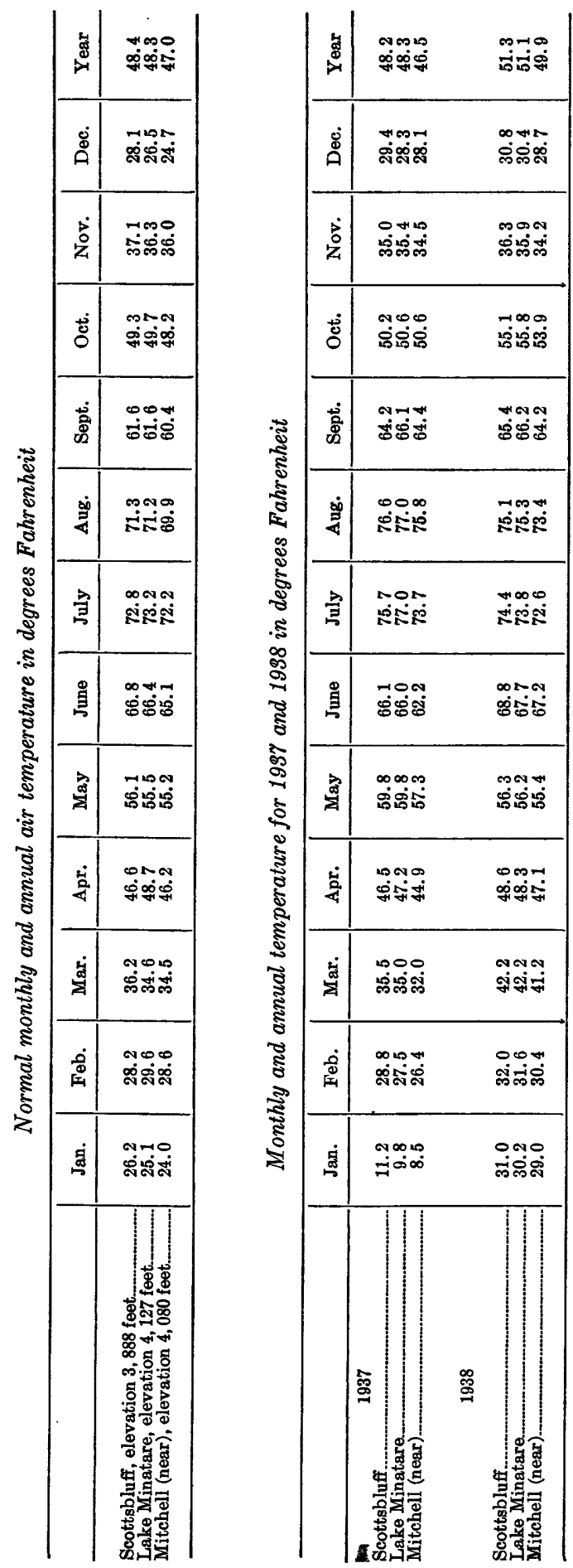

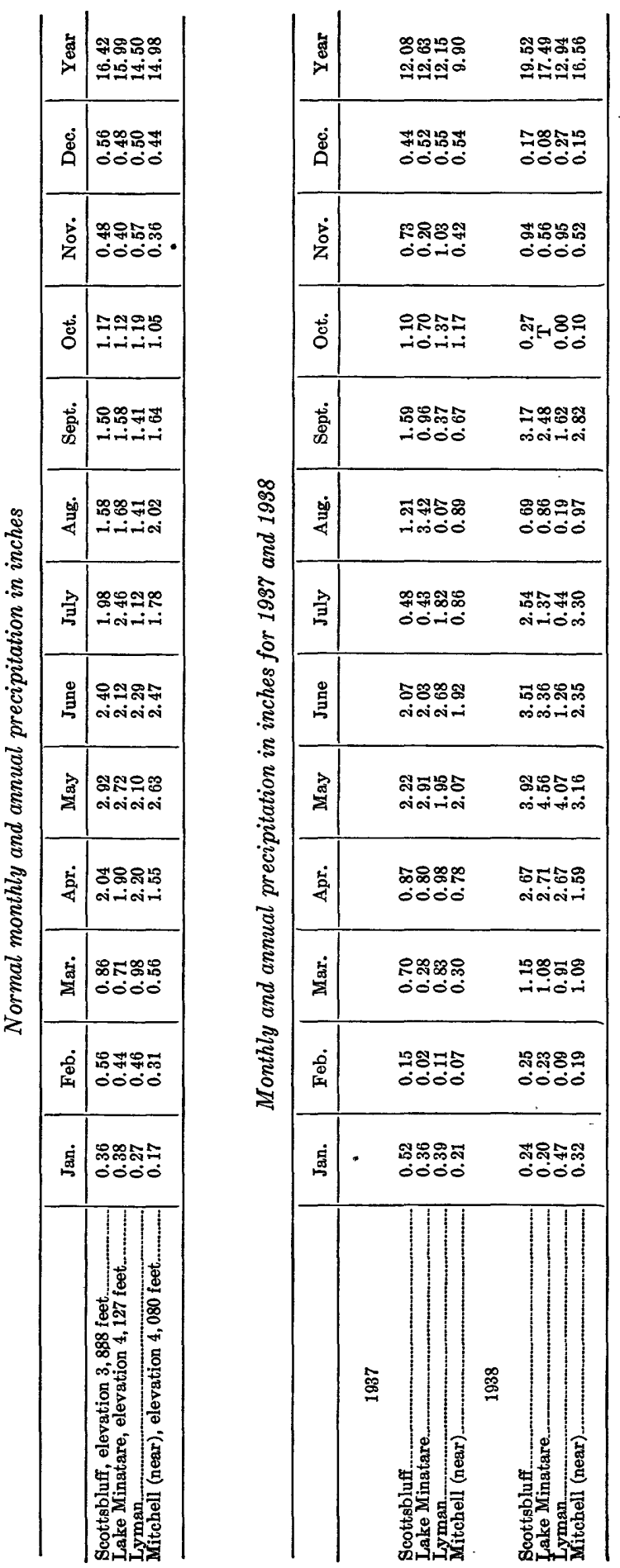
Annual precipitation at Scottsbluff, 1889 to 1938

\begin{tabular}{|c|c|c|c|c|c|}
\hline 1889. & $\begin{array}{l}\text { Inches } \\
.16 .33\end{array}$ & 1906. & $\begin{array}{r}\text { Inches } \\
21.97\end{array}$ & 1923 & $\begin{array}{r}\text { Inches } \\
20.30\end{array}$ \\
\hline 1890. & 11.06 & 1907. & 13.42 & 1924 & 11.52 \\
\hline 1891. & .21 .12 & 1908 & 17.03 & 1925 & 16.49 \\
\hline 1892. & 20.51 & 1909 & 19.18 & 1926 & 14.00 \\
\hline 1893. & 9.82 & 1910. & 9.91 & 1927 & 21.19 \\
\hline 1894. & 11.78 & 1911. & 15.27 & 1928 & 15.41 \\
\hline 1895. & .11 .14 & 1912 & 21.60 & 1929 & 17.67 \\
\hline 1896. & 14.89 & 1913. & 16.61 & 1930 & 17.26 \\
\hline 1897. & .11 .43 & 1914 & 10.39 & 1931 & 9.47 \\
\hline 1898 & 14.08 & 1915 & 27.48 & 1932 & 14.51 \\
\hline 1899. & 19.16 & 1916 & 12.55 & 1933 & 14.64 \\
\hline 1900. & 15.19 & 1917. & 17.26 & 1934 & 11.12 \\
\hline 1901. & 17.26 & 1918 & 22.68 & 1935 & 18.89 \\
\hline 1902 & 18.25 & 1919 & 12.33 & 1936 & 13.12 \\
\hline 1903. & 12.98 & 1920 & 18.26 & 1937 & 12.08 \\
\hline 1904 & .11 .30 & 1921 . & 12.62 & 1938 & .19 .52 \\
\hline 1905. & 23 & 1922 & .16 .95 & & \\
\hline
\end{tabular}

\section{SOIL AND VEGETATION}

Detailed descriptions of the soils are contained in the report on the soil survey of the Fort Laramie area in Wyoming and Nebraska, by A. O. Veatch and R. W. McClure, and the report on the Soil Survey of Scotts Bluff County, Nebr. by L. T. Skinner and M. W. Beck, both issued by the Bureau of Soils, United States Department of Agriculture, Washington, D. C. The soils of the upland areas belong to the Rosebud, Valentine, Orella, Goshen, Dawes, and Canyon series; the terrace, or second-bottom soils, belong to the Tripp and Cheyenne series; and the first-bottom or flood-plain soils belong to the Laurel, Minatare, and Orman series. The Rosebud series are grayish to light-brown residual soils developed on the Arikaree sandstones. The Valentine series consist of recent soils developed on the mantle of wind-blown sand that covers much of the land surfaces above the flood plain. It is to be distinguished from dune sand. The Orella series occupies low flat lands underlain by Chadron and Brule fine-grained sediments, and is derived from the weathering of these formations. The Goshen series is similar to the Rosebud and may be regarded as a poorly drained phase of it. Goshen soils occur in swales in headwater flats of the uplands. The Dawes series is also similar to the Rosebud but has a greater concentration of mineral salts and a less pervious subsoil. The Canyon series is derived from fine-grained wash from Tertiary sediments and-occupies rolling to hilly areas where slopes are steep. The Tripp series is characterized by a loose surface soil with a heavier subsoil layer and is developed on the low alluvial terraces of the North Platte River and its larger tributaries. The Cheyenne series has a porous substratum and no heavy subsoil layer, but its mode of occurrence is similar to that of the Tripp. The Laurel series, occupying the flood plain, is a thin soil developed on a coarse alluvium. Soils of the Minatare series are plastic, fine-grained, dark-colored, poorly drained, and alkaline. They overlie a substratum of gravel. The Orman series is dark and impervious and contains much organic matter.

The dominant natural vegetation in Scotts Bluff County is grass. Sandgrass, stipa, buffalo grass, bunchgrass, and grama are the most common varieties on the uplands. "Wild hay" grows profusely in un- 
drained or swaley areas, such as abound along the flood plain of the river; it consists chiefly of the upland varieties associated with blackroot, western wheatgrass, saltgrass and marsh grasses. Yucca, or soapweed, and sage characterize areas of dune sand. Trees are locally numerous; in the rough uplands, chiefly in Wildcat Ridge south of the river, stunted pines and small cedars form a sparse forest, with a few shrubs such as mountain-mahogany, and wild plum. Along the river are thickets of cottonwood, willow, buffaloberry, and boxelder. Cattails have invaded areas kept moist by seepage from irrigation canals.

\section{IRRIGATION}

Most of the tillable land in Scotts Bluff County is irrigated. Records collected by the 15th Census show that in 1930 the county contained 1,793 farms, of which 1,609 , or about 90 percent, were irrigated by water diverted from streams or by water pumped from wells. Of 378,683 acres of land included in farms in 1929, 193,816 acres, or about 51 percent, were irrigated.

Irrigation has been carried on to some extent in Scotts Bluff County almost since the advent of the first agricultural settlers. In the 1880 's many farmers realized that the precipitation in the county, which is nearly the lowest for any part of Nebraska, was insufficient in most years to produce successful crops, and that supplemental water was essential. The farmers naturally turned to the broad swiftly-flowing North Platte River, which at that time seemed to constitute an unlimited supply, and soon constructed canals and diversion dams to lead the water to their fields. According to Darton ${ }^{4}$ the Winter Creek, Minatare, and Enterprise canals were built in 1888 and 1889, although the Enterprise canal was not completed until somewhat later. The Mitchell, Ramshorn, Gering, Castle Rock, Farmers, and Bayard canals were constructed at about the same time or a little later. These canals served land on the lower terraces, to which water from the river could be conducted with much less expense and difficulty than to the higher lands lying farther back.

The irrigators soon felt concern lest water users upstream from them divert so much water from the river during periods of low flow that the quantity reaching the headgates of their canals would be inadequate to supply their demands. They directed appeals to the State Legislature to enact laws and set up a governing body to protect their water rights. Considerable publicity was given to these demands, public attention became focused on irrigation and its relation to agriculture in Nebraska. The publicity thus given to irrigation reacted unfavorably on some residents of central and eastern Nebraska, who had migrated from the eastern part of the United States and in whose minds irrigation was associated with desert regions where people struggled along on a few acres of land to produce a scant living. They believed that the agricultural reputation of the State would be ruined and the influx of farmers would cease, if it were found that irrigation was necessary. The irrigators for a time experienced considerable opposition to their demands for protective legislation, but the success and merit of the irrigation enterprises were proven during a series of dry years in the early nineties

\footnotetext{
4 Darton, N. H., Preliminary report on the geology and water resources of Nebraska west of the 103d meridian: U.S. Geol. Survey Prof. Paper 17, pp. 54-55, 1903.
} 
when crop failures were widespread on unirrigated land of the State. Legislation favorable to irrigation was passed in 1895, public opinion swung to the opposite extreme, and many people contended that all the land in Nebraska could be, and eventually would be, irrigated by water obtained from streams or from underground sources.

Gradually, it was seen that in some areas in the State the supply of water for irrigation was inadequate, the soil unadaptable, the slope of the terrain unfavorable, or the cost of supplying water to the fields exorbitant. The development of irrigation then became a matter of individual or group initiative of those who had the good fortune to settle in areas where conditions for irrigation were most favorable.

In Scotts Bluff County irrigation developed rapidly; the soils proved particularly adaptable, the yield of irrigated crops large, the slope of the land good, and the supply of irrigation water reasonably adequate. In 1889 Scotts Bluff County had the third largest irrigated acreage of any county in the State-2,743 acres. By 1899 the irrigated acreage in the County had increased to 29,244 , and the county then assumed a lead in irrigated acreage in the State that it did not lose, about 100,000 acres being irrigated in 1909, about 173,000 acres in 1919, and about 194,000 acres in 1929. The irrigated acreage in Scotts Bluff County in 1929 constituted about 46.5 percent of the total irrigated land of Nebraska.

The Nebraska Statutes provide for the distribution of water from streams on the basis of priority of claim or application. A list of claims and applications given in the twenty-second biennial report of the Department of Roads and Irrigation ${ }^{5}$ show that the first appropriation for diversion from the North Platte River in Scotts Bluff County was granted to the Farmers Irrigation District and was given September 16, 1887 , as the date of priority. The appropriation was for 905 cubic feet a second. The list indicates that appropriations in Scotts Bluff County dated prior to 1890 total about 1,500 cubic feet a second, and those dated prior to 1900 total slightly more than 2,100 cubic feet a second.

By 1900 the early optimism regarding the adequacy of the supply of the North Platte River for irrigation was proved to be unfounded. During periods of low flow almost all the water was diverted from the river in the extreme western part of the State and little if any was left for canals downstream. H. H. Pickens, ${ }^{6}$ of the State Board of Irrigation, wrote of conditions in the North Platte River in August 1898: "I found the North Platte River practically dry to the east line of Cheyenne County (now Morrill County), something rarely, if ever, known before. This unexpected failure of the water supply resulted in serious losses to the farmers."

The contrast between nearly complete utilization of the waters of the North Platte during irrigation seasons and the tremendous wastage during spring floods directed attention toward the possibility of retaining in storage a part of the spring runoff for use in subsequent months, when the normal flow of the river is low. Soon after the Reclamation Act of June 17, 1902, was passed, investigations were started for the purpose of ascertaining the irrigation possibilities of the North Platte drainage area in Wyoming and Nebraska. These investigations led to the con-

6 Nebraska Dept. Roads and Irrig., 22d Bien. Rept., pp. 236-39, 1937-38.

- Pickens, H. H., in Nebraska State Engineer, 2d Bien. Rept., 1897-98, p. 205, 1899. 
struction of water facilities described by the Bureau of Reclamation, ${ }^{7}$ as follows:

Water for irrigation is obtained by the storage of flood water of North Platte River in Pathfinder and Guernsey Reservoirs, having a conbined capacity of 1,141,060 acre-feet at spillway level. The Pathfinder Dam, one of the largest masonry dams in the world, rises 218 feet above its rock foundation. This storage is supplemented by smaller reservoirs on the Interstate Division. Economy in distribution is secured by regulation at the Guernsey Reservoir. Power plants located near Lingle, Wyoming, and at the Guernsey Dam furnish electrical energy for the needs of the project. Pathfinder Reservoir is located about 50 miles southwest of Casper, Wyoming. Water is released as needed and flows down the North Platte River for a distance of 168 miles to the Guernsey Reservoir which acts as a regulating reservoir. This reservoir is located approximately 7 miles above the Whalen Diversion Dam, where the water is diverted into the Interstate canal which carries water for the irrigable land under the Interstate Division on the north side of the river and into the Fort Laramie canal which carries water for the irrigation of the irrigable land under the Fort Laramie Division on the south side of the river. A diversion is also made near the State line through the Tri-State canal of the Farmers Irrigation District to water irrigable land under the Northport Division. The storage reservoirs, the Whalen Diversion Dam and the power system are operated and maintained by the Bureau of Reclamation. The water is distributed to each individual tract of land through a network of canals and laterals operated and maintained by the Pathfinder Irrigation District on the Interstate Division; the Goshen Irrigation District and the Gering and Fort Laramie Irrigation District on the Fort Laramie Division; and the Northport Irrigation District on the Northport Division. The water supply is ample for the land to be irrigated and surplus water has been sold to private irrigation districts in the valley, subject however to the prior right of use for the lands under the project."

The Interstate canal enters Scotts Bluff County from Sioux County about 18 miles east of the State line and continues into Morrill County; the Fort Laramie canal enters directly from Wyoming and ends in southeastern Scotts Bluff County. Both canals traverse the higher terrace lands of the valley and serve much of the land that cannot be reached with water from the older canals. Notable features connected with these enterprises in the county are Lake Alice and Lake Minatare, storage reservoirs northeast of Scottsbluff, with a combined capacity of about 72,000 acre-feet, and a tunnel about 4 miles west of Scotts Bluff National Monument through which water in the Fort Laramie canal is conducted beneath a high ridge to Cedar Valley.

A myriad of canals, laterals, and ditches (fig. 2) have been built in Scotts Bluff County in order to make water available to the farms. According to the 15 th Census there were 314 miles of main canals and 916 miles of laterals in Scotts Bluff County in 1930. In addition, there are many miles of smaller ditches. The aggregate capacity of the main canals in 1930 was more than 4,000 cubic feet a second.

The intensive application of surface water to the land in Scotts Bluff County has raised the ground-water level considerably throughout most of the county and has greatly increased the flow of many small streams. Drainage ditches have been constructed in order to prevent the groundwater level from rising sufficiently close to the land surface to harm the growth of crops. In 1930, according to the census, approximately 142,000 acres, about 73.5 percent of the land irrigated in the county, also were served by drainage enterprises. Scotts Bluff County contained about 143 miles of drainage ditches in 1930 .

The great extent to which irrigation has affected ground-water and surface-water conditions is well illustrated by the increase in volume of inflow to the North Platte River from the small streams of the area.

\footnotetext{
7 U. S. Bur. of Reclam., North Platte Irrig. Dist., Nebraska-Wyoming, Map No. 23600, 1930.
} 


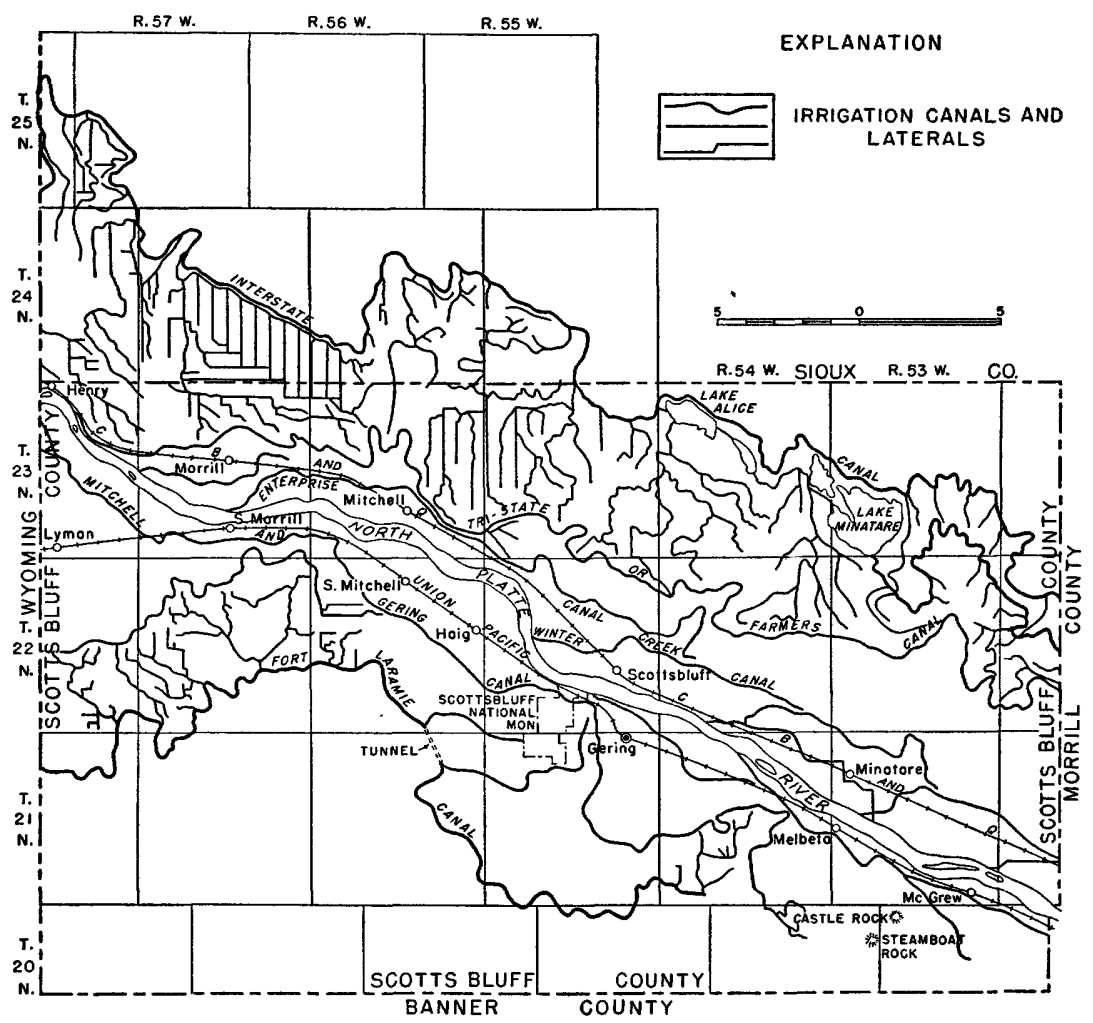

Frgure 2.-Map of Scotts Bluff County and southwestern Sioux County, showing main irrigation canals and laterals.

The surface inflow between the State line and Bridgeport increased from less than 25,000 acre-feet in 1911 to nearly 700,000 acre-feet in $1927 . .^{8}$ Since 1927 the annual inflow has ranged considerably but in no year has it fallen below 300,000 acre-feet. In the water year ending September 30,1938 , the surface inflow to the river between the State line and Bridgeport was 441,616 acre-feet. ${ }^{9}$ In addition, 53,304 acre-feet was diverted from the streams, creeks and drains above their confluences with the river, making a net surface inflow of nearly 500,000 acre-feet. During the same period the discharge of the North Platte River at the Wyoming-Nebraska State line was 544,400 acre-feet, which was only about 10 percent more than the net surface inflow between the State line and Bridgeport. A large volume of water is, however, brought into the county each year in the Interstate and Fort Laramie canals, and hence the discharge of the tributaries in 1938 was considerably less than the total surface inflow to the county.

Nebraska Dept. Roads and Irrigation, 22d Bienn. Rept., 1937-38, p. 693.

Op. cit., p. 694 . 


\section{LAND FORMS}

\section{MAJOR FEATURES}

Scotts Bluff County occupies an area where the High Plains have been deeply and extensively eroded. During the Tertiary period rivers from the Rocky Mountains deposited gravel, sand, silt, and clay in the form of a great alluvial piedmont plain, whose original surface would now lie at an altitude of 5,000 to 6,000 feet above sea level in Scotts Bluff County. Since Tertiary time the trunk rivers and their tributaries have changed from agents primarily of deposition to agents primarily of erosion, and great valleys have been cut into the plains. The North Platte River has cut a valley about 1,000 feet deep through which it flows southeastward from the northwestern corner of the county to the southeastern corner. (See pl. 1.) The inner valley, consisting of the flood plain and the lower slopes, is 5 to 8 miles wide. Here are the towns, the routes of transportation, and the intensive agriculture that has been made possible by irrigation. On either side of the inner valley are the rough higher slopes and table lands of the old valley, land forms that were hewn out chiefly during past erosion cycles. Even the table lands and buttes that at first glimpse appear to be a part of the High Plains are in reality incompletely degraded portions of the old valley.

Probably the first feature that a stranger would observe on entering the North Platte Valley in Scotts Bluff County is the magnificent bluffs that tower above the river on the south side. These bluffs are the riverward boundary of a ridge, or table-land remnant, which parallels the river from a point beyond the eastern border of the county almost to the Wyoming State Line. This upland remnant is the divide between the valleys of the North Platte River and Pumpkin Creek, and is called Wildcat Ridge. The side of the ridge adjacent to the North Platte River has been frayed by stream erosion into a succession of deep and wide reentrants separated by narrow but prominent salients that jut out to within a mile or two of the river. Chimney Rock is the northeasternmost point on one such salient, just east of the county line; Castle Rock, Table Rock, Steamboat Rock, and several other nearby prominences comprise a somewhat eroded salient; another, still nearer to complete destruction may be seen in the low hills southwest of Minatare; the largest, most prepossessing, and best known salient is Scotts Bluff, near Gering and Scottsbluff. This mass has been cut off from the rest of the Wildcat Ridge by streams in Cedar Valley that cut back toward the west. A sweeping concave slope rises from the flood plain of the river to the foot of the bluffs. This slope is steepest where the bluffs approach nearest the river, and is rather flat in the reentrants. The bluffs themselves are most precipitous at the points of the salients. Scotts Bluff stands nearly 800 feet above the river, of which about 500 feet is practically a vertical cliff. In the parts of the reentrants most distant from the river the bluffs are in some places covered with colluvial detritus to form a graded slope. Because Wildcat Ridge is a narrow upland, and because the distance from the river to the bluffs is short, the tributary streams have small drainage areas, and are ephemeral or intermittent. In flowing over soft rock, however, they have cut deeply into the upland. In the southwestern part of the county Wildcat Ridge has been eroded away completely, the divide between the North Platte and Pumpkin 
Creek valleys being a low pass at the head of a deep reentrant. The lowland in the northern part of the reentrant will be referred to as the Lyman plain. Owl, Kiowa, and Horse creeks flow from the highlands through it to the North Platte River.

The appearance of the northern side of the North Platte Valley in Scotts Bluff County is quite unlike the southern side. Instead of the slope and the bluffs, one sees a gentler sloping, broader land surface rising toward no prominent bounding escarpment. The slope of this surface is not uniform, but is broken up into a succession of wide, sloping terraces. The northern side of the valley rises more abruptly in the northwestern part of the county than in the eastern part. On this sloping surface are some prominent terrace remnants in the form of hills that are aligned in a direction about parallel to the river 6 to 8 miles back from it. These hills are also elongated in the direction of their alignment. They stand 100 to 200 feet above the surrounding terrain but have no great areal extent. Behind them is a second line of hills separated from one another and from the upper slopes of the valley by lowlands formed during subsequent erosion cycles.

The tributary streams that enter the river from the north occupy long narrow valleys, which head far up in the higher slopes of the North Platte Valley, although not on the highest upland levels. Sheep Creek enters the inner valley at a point about $1 \frac{1}{2}$ miles west of Morrill. It heads about 30 miles north of the river in Wyoming, and is the longest of the tributaries that enter the river from the north in Scotts Bluff County. The valley is narrow, with a well-developed terrace below which the stream has cut a shallow channel. The stream shows evidence of having possessed erosive power in fairly recent geologic time, but at present its valley is obstructed with a deposit of dune sand at a point about 3 miles north of the Scotts Bluff County line, in Sioux County. Other sand hills have partly closed the mouth of the valley. Sheep Creek has a tributary that meets it a short distance south of the Sioux County line. This tributary is called Dry Sheep Creek and heads about 10 miles north of the river, in Sioux County. Near its head the stream occupies an extensive lowland that it has not dissected since before the last two cycles of downcutting; an abrupt change in gradient of the valley floor separates this part of the valley from the lower reaches where the stream has been actively eroding in rather recent time. The Interstate canal crosses Dry Sheep Creek at this break in slope.

Another pair of streams enter the valley of the North Platte northwest of Mitchell. The streams do not actually meet, but their valleys are so similar and so close together that they have been named Dry Spottedtail and Spottedtail creeks. Dry Spottedtail Creek heads about 18 miles north of the river in the rugged topography of the outer valley. The headwaters of Spottedtail Creek mingle in with those of Dry Spottedtail, but its most distant headwater tributaries empty into an undrained remnant of a land surface that has not been dissected by recent stream action. Low terraces are prominent in both valleys.

A pair of unnamed valleys join at the point where they debouch on to the floor of the lower valley of the North Platte, about half way between Mitchell and Scottsbluff. Neither of these valleys has been dissected during the last two erosional stages. They meet upstream in section 4, T. 23 N., R. 55 W., almost at the Sioux County line to form a single valley. The uppermost reaches of the valley are occupied by active and 
eroding headwater tributaries that have been cutting into the escarpment and the higher levels beyond, but at a point southwest of Wind Springs they empty onto an old land surface that has not been recently dissected.

Winter Creek enters the inner valley of the North Platte about 2 miles northeast of the city of Scottsbluff. Its valley is narrow in most places, but like most of the other tributaries on the north side of the North Platte, it crosses undissected lowlands or basins that were formed during previous erosion cycles. Such lowlands are those now occupied by Lake Alice and Lake Minatare. Terraces are prominent in Winter Canyon.

Ninemile Creek is the tributary that comes into the valley farthest east in Scotts Bluff County. Essentially it is similar to Winter Creek. Its continuity is interrupted in its middle reaches: the headwater branches join and flow to a flat and undissected portion of its valley in section 14 , T. 22 N., R. $53 \mathrm{~W}$., where they disappear, and the lower part of the stream, having eroded headward, is now attacking this surface.

\section{ASYMMETRY OF THE NORTH PLATTE VALIEY}

The North Platte Valley is asymmetrical in cross section, having a northern side that slopes more gently, with terraces preserved on it, whereas the south side is steep, with a rock-cut slope sweeping upward and breaking into bluffs near the top. Terrace remnants are almost wholly lacking on the south side. A profile of the land surface across Pumpkin Creek Valley, over Wildcat Ridge, thence across the North Platte Valley shows that Pumpkin Creek Valley is also asymmetrical, but its steep wall is on the north, and terrace levels are preserved on the more gently-sloping south side, in contrast to the form of the North Platte (fig. 3). The asymmetry of both valleys seems to be caused by the unequal distribution of gravel on the table lands near them, and on their slopes.

A high-level gravel lies on remnants of the plain top north of the North Platte Valley in the southern part of Sioux County at elevations of 4,900 to 5,000 feet. At no place were the deposits that remain observed to be over 15 feet thick. The original deposit must have been extensive, and probably thicker than those that are preserved. The terraces cut on the north side of the North Platte are mantled with sheets of gravel 5 to 30 feet thick, which contain fragments of soft sandstone and, in certain places, large cobbles. Moreover, they show current features that indicate movement of the material down the valley side, and they become increasingly finer and more rounded toward the lower terraces. It is therefore concluded that most of the gravels were brought down to their present resting places by tributary streams during the excavation of the valley. The mantle of gravel has protected the terrace surfaces cut on the soft Brule formation. The table land south of the river, being narrow, could furnish but little gravel if it existed there. Consequently, the south slope of the valley, without a protecting mantle of gravel, has been planed down pretty much in accordance with the level of the river, and the older terrace levels have been destroyed. The tableland south of Pumpkin Creek Valley carries a thick and extensive deposit of gravel of Tertiary age which has been washed down upon the south slopes of the valley of Pumpkin Creek. The gravel not only preserves the old terrace levels but also has forced Pumpkin Creek close to the steep north wall of its valley. Thus Pumpkin Creek Valley is also 


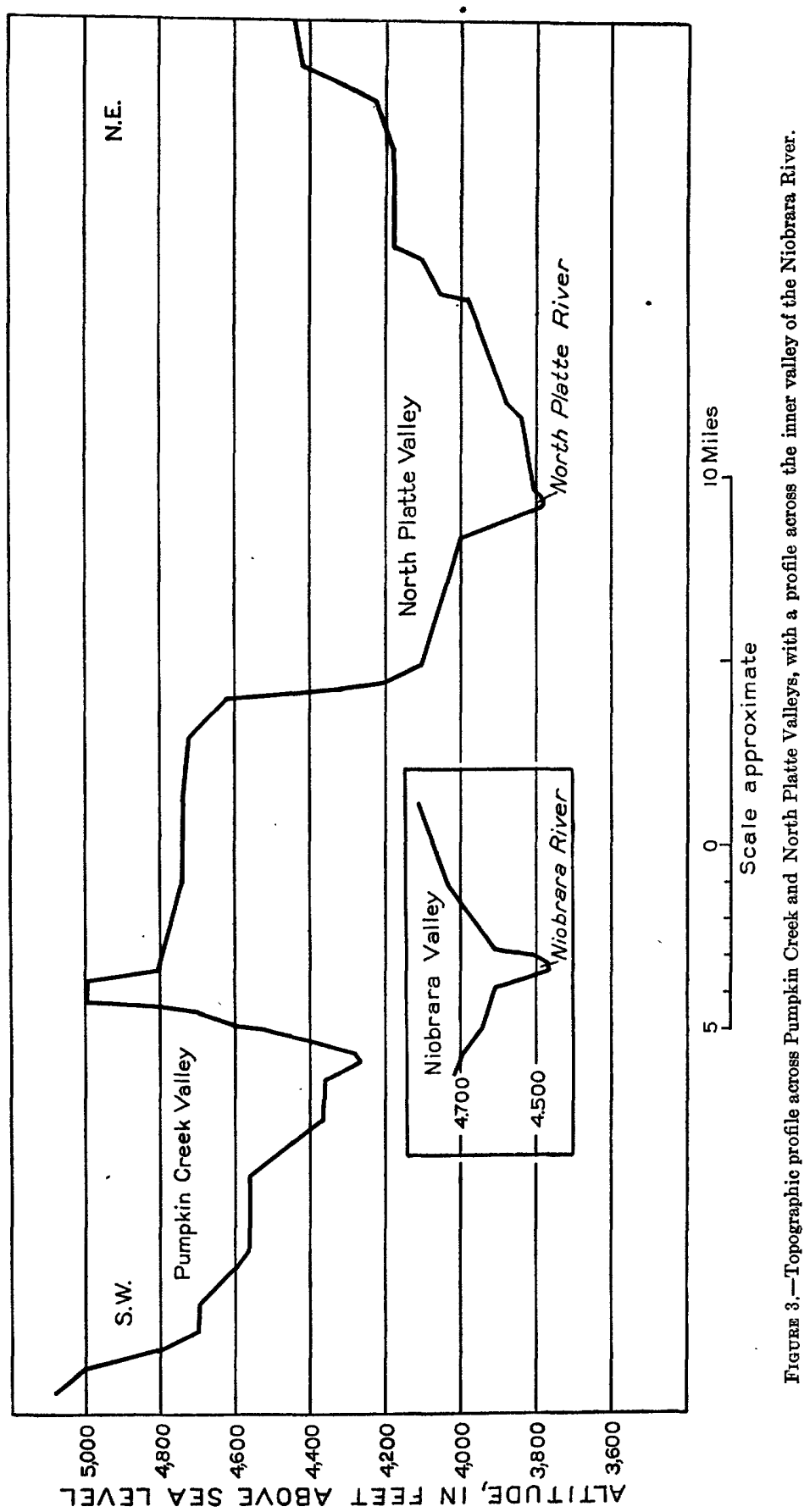


asymmetrical, but its asymmetry is opposite to that of the North Platte Valley. A profile across the upper Niobrara Valley in Sioux County to the north shows that it is symmetrical in cross section. (See fig. 3.) Very little gravel, if any, occurs on the upland plain near the Upper Niobrara.

It is necessary to describe the land forms in the North Platte Valley in terms of their mode of origin, and their place in the chronology of the valley's history. Time and processes belong to their dimensions as much as width and height. Running water has been the chief agent in carving out the valley and in producing its constituent land forms. Accordingly the workings of running water will be discussed first. A few signs of wind action in the area are evident, and these will be discussed on pp. 50 to 52 .

\section{STREAM PROCESSES}

\section{FLOOD PLAIN}

The nature of the flood plain of the North Platte and the present-day behavior of the river are intimately related. At the outset one meets with the fact that the Platte River, particularly that part which flows through central and eastern Nebraska, has long been considered an example of a braided, alluviating, fully laden, or overladen stream. This concept has been flatly contradicted by Lugn, ${ }^{10}$ who holds that the river flows over deposits of alluvium, largely gravel, which was deposited in Pleistocene time, and which the river has not disturbed to any considerable extent since. Much less than depositing silt and coarser detritus, he considers the Platte to be at least until very recent time a degrading stream. Likewise, in Scotts Bluff County the North Platte River runs over a gravel-filled channel of Pleistocene age, buried beneath the flood plain, and the river, until recently, has been eroding, not aggrading.

The North Platte River flows through Scotts Bluff County at an average grade of about 6.3 feet to the mile. Its discharge, measured at Gering during the warm months between 1897 and 1900, before the river was regulated but not before water was diverted for the irrigation of many acres of land, ranged from about 100 to over 16,000 cubic feet a second and averaged about 4,785. The grade of the river bed is exceptionally high for a stream of the size of the North Platte. At Clay Center, Kan., where the drainage basin of the Republican River is of about the same size as that of the North Platte above Bridgeport, the river has a gradient of only 3.2 feet to the mile, and even in south-central Nebraska, near Red Cloud, relatively farther upstream than Bridgeport, the gradient of the Republican is only 4.8 feet to the mile. At ordinary stages the North Platte flows across Scotts Bluff County at a rather high velocity and without carrying much suspended sediment. On either side of the river banks is a flat flood plain having an average width of about a mile. It is a little wider in the eastern part of the county than in the western part. The channel of the river, about 5 to 10 feet lower than the level of the flood plain, is in many places fairly choked with islets, and it splits and gathers in a tortuous fashion. It does not meander. The North Platte, is, in short, a braided stream. The flood

${ }^{10}$ Lugn, A. L., The Pleistocene geology of Nebraska: Nebraska Geological Survey, Bull. 10, 2d ser., pp. 88-91, 1935 . 
plain of the North Platte is in some respects not typical of those constructed by many heavily loaded streams, particularly those in humid regions. In the first place the natural levees, a very common feature of the true flood plain, are either imperceptible or absent in Scotts Bluff County.

Discussion of the flood plain is immediately complicated by the fact that its exact vertical limits cannot be defined. The river runs over a buried gravel-filled channel of late Pleistocene age. Moreover, since that time the river probably has cut below its present level into the channel fill on two or more occasions: during the dissection of the first and second terraces. Thus there is good reason to believe that down to some unknown depth below the river the alluvium has been reworked.

The nature of the material in the flood plain requires some consideration. The material in the bottom of the river channel and on some of the islets consists of fine sand and silt. Excavations in the flood plain and samples taken from test holes and wells drilled into it, however, show that coarse sand and fine to medium gravel are abundant in the floodplain deposits. This is masked by a covering of fine material, not only near the river channel but also over most of the surface of the flood plain. The covering on the flood plain proper seems to be from 2 to 6 feet or more in thickness, and to be composed of gray silty material similar to the mantle of eolian sediment that is widely distributed over higher land surfaces in the county. The damp flood plain would be a natural place for wind-blown dust to be fixed. However, within the fine silt are interbedded thin layers of fine to coarse sand deposited by the river during floods. It is significant that the small channels, which wander over the flood plain and are occupied by running water only during moderate flood stages of the river, cut through this fine-grained mantle into sand and gravel, suggesting that the fine material has been accumulating slowly for some time.

Flooding of the North Platte is thought to be an important aspect of its behavior, but it cannot be discussed authoritatively, because early streamflow records are lacking, and historical mention of floods is not factual. Within the memory of living inhabitants of Scotts Bluff County the river is reported to have overflowed its banks and reached the southern end of the business section of Scottsbluff on two occasions. This rise represents a flood stage of probably about 6 or 8 feet above normal. No definite idea can be obtained of the discharge of the river at this stage, but at the old stream-gaging station on the south end of the Scottsbluff-Gering bridge a gage height of 3.35 feet was accompanied by a discharge of almost 26,000 cubic feet a second in June 1897. A flood reaching to the level of the bridge would mean a gage height of $6.61 \mathrm{feet}$, with a discharge that would probably equal 100,000 second-feet or more. This would be about 4 second-feet per square mile of drainage basin upstream from Scottsbluff, and equal to one-half the maximum discharge recorded in 1935 at Clay Center, Kan., during the great flood on the Republican River. A flood reaching the top of the bridge would cover much of the flood plain. Unlike the Republican, the North Platte River above Scotts Bluff County is largely a mountain stream, and before it was diverted and regulated it habitually rose to moderate flood peaks because of the melting of snow late in spring or early in summer. Upon these chronic floods were superimposed the discharge derived from local runoff, for June is likely to be one of the rainiest months in the year. Such com- 
binations of snow melt and local precipitation have great possibilities for producing high runoff. Thus, a peak discharge of 200,000 second-feet at Clay Center, Kan., represents the flattened crest of a "hundred-year" flood of the Republican River originating many miles upstream. It is possible that flood discharges intensified by local precipitation of as much as 250,000 second-feet or even more, might have been experienced occasionally on the North Platte in Scotts Bluff County, not considering, of course, the effects of artificial control.

The North Platte River in western Nebraska, having a grade of 6.5 feet to the mile, does not meander. It is not heavily laden, with debris in ordinary stages, yet it is braided. Its flood plain, which probably has been aggraded several feet since the dissection of the lowest terrace, has been constructed chiefly of coarse sand and gravel, but superficial material of fine grain has been accumulating on it for some time without being disturbed. The reason for its braided form seems to be in the facts of its habitual flooding, and in the coarseness of its transported load. True, before regulation, the North Platte was probably a losing stream because of heavy transpiration losses; but these losses would be insignificant during flood stages when most of the sediment, which is coarse, was being carried. Gravel and sand are abundant in the drainage basin of the North Platte in western Nebraska and Wyoming, and the river in high stages was probably loaded with sediment up to the limit of its competence with respect to grain size. When the floods ebbed, the load of sediment was dropped indiscriminately in the channels and on the flood plain. If the debris were of fine grain, the river would then rework it, cut the bars and fill the deeps, develop an efficient channel, and perhaps meander. Actually, however, during low stages the river is not competent to rearrange its coarse load, hence its channel is blocked, tortuous, and braided. It can only cover its coarse deposits with a scanty film of silt.

Many rivers that are aggrading slowly remove sediments from their valleys for long periods between major floods but at high stages introduce a vastly greater amount of sediment than they were able to carry out. Some rivers, on the contrary, deposit material in their valleys at low stages, and remove it, and more, during floods, with a net loss over a long period of time. It would be difficult to determine if a river were truly at grade, with no net loss or gain in sediment in its channel and flood plain. Also, a stream may be degrading in one section of its course, at grade in another section, and aggrading elsewhere. The North Platte having finished a minor period of downcutting, probably has been in a minor phase of aggrading during the past few centuries.

\section{BLUFFS AND PEDIMENTS}

The walls of the North Platte Valley have attained their present form chiefly through the erosive action of the tributary streams. On the north side of the valley the surfaces cut upon the Tertiary sediments by these streams at successively lower levels have been protected by a thin mantle of gravel, and so preserved as terraces. They will be discussed later under that heading on pp. 28-48. On the south side of the valley, where no covering of gravel exists, the higher and more ancient land surfaces have been destroyed by more recent erosion.

This south slope of the valley, as it now exists, is composed of three main elements, the bluffs, the slopes from the top of the bluffs to the 
upland, and the lower slopes that descend gradually from the foot of the bluffs to the valley bottom. The bluffs are nearly vertical, but above them the land slopes up and back toward the upland with a broad convex profile; and from the foot of the bluffs the land slopes downward toward the river with a sweeping concave profile.

The Tertiary formations that make up the High Plains in western Nebraska, into which the North Platte River has cut its valley, are not homogeneous in their resistance to the agents of weathering and erosion. The river has cut down to a depth of more than 1,000 feet below the original plain top, of which the upper 600 feet has been through the Arikaree sandstones, including the Gering, of Miocene age, and the lower 400 feet has been through the Brule formation, of Oligocene age. (See pl. 2.) The upper sandstones of the Arikaree group and to a lesser extent, the Gering formation contain numerous hard concretionary layers that make the Arikaree as a whole relatively resistent to erosion, whereas the Brule formation, composed chiefly of compacted silt, has very little resistance to weathering and erosion. The Arikaree sandstones form the upland plateaus and the upper parts of the bluffs, and the lower part of the bluff faces and slopes below them have been cut on the Brule formation.

It has been pointed out that the bluffs on the south side of the river follow an arcuate course, approaching the river at the narrow salients and swinging back several miles in the broad reentrants; the Brule slopes, in complementary relation to them, are of course most extended in the reentrants. This arcuate form is an inheritance from early stages of the erosion of the valley. The reentrants were once the sites of the major tributary valleys, here called streams of the first magnitude, before they and the river had cut through the Arikaree sandstones into the Brule formation.

Within the major arcs described by the bluffs are smaller embayments, whose sites are determined by small streams of a second order of magnitude that occupy minor valleys embracing considerable drainage area on the upland surface of Wildcat Ridge. The streams of the second order of size are very regularly spaced, and the embayments they have produced are in most places about a mile wide and perhaps a mile deep. The streams are ephemeral and appear to head in the box canyons or embayments, but in reality they have their sources in the upland above the bluffs. There they occupy shallow, gently sloping valleys, which steepen perhaps a quarter of a mile back and reach a maximum grade at the bluffs, where the streams descend as cataracts. Above the brink of the bluffs, where the grade is steepest, these streams are eroding the lower beds of the Arikaree sandstones, accomplishing this task chiefly by removing the loose sandstone and thus exposing the hard areally discontinuous concretionary layers. As one of these layers is exposed, a small waterfall is formed; the stream undermines the layer and begins to flow under it from behind, leaving the concretion to break up of its own weight. Thus the headward erosion is accomplished by cutting down through the Arikaree, rather than undermining it by cutting away the Brule.

A smaller class of stream is also attacking the bluffs by headward erosion. These streams of the third order of magnitude may or may not be tributaries of streams of the second order described in the previous paragraph. They are ephemeral and carry flood waters down a steep channel from drainage basins of a few acres' extent on the upland. 
They are regularly spaced and numerous. In the southwestern corner of Cedar Valley, southwest of Gering, there are 14 of these streams of the third order within a linear distance of about 2 miles along the bluffs. In this locality each 3 to 6 of them together join to produce a minor embayment in the bluffs, having an area of a quarter to half a square mile. Each embayment, strikingly uniform in size, is separated from those adjacent by a bold, bastionlike salient.

By far the greatest part of the bluffs are not acted upon by any of the streams discussed above, nor are they undercut by any streams flowing parallel to the foot of them. It would follow that sharp spurs would be formed between the streams that are cutting back into the bluffs if no other agent than those mentioned were engaged in modifying them. The remarkable wall-like regularity of the bluffs and the rounded form of the spurs have been cited, indicating that the bluffs are retreating in the stretches between the streams almost as rapidly as in places where the small streams of the third order are most active. The bluffs are less than vertical, and hence it is evident that the Arikaree cover is not being undermined. Examination of the face of the bluffs discloses the fact that literally hundreds of small rill marks or miniature gullies, not very deep or very wide, have been cut. For instance, in the mile stretch of bluffs, mentioned above, where 14 small streams are cutting back, 66 noticeable rill marks can be seen. These rill marks have been made by water that falls as rain almost entirely upon the slope above the bluff and upon the bluff face itself, for practically no drainage basin exists for them on the upland. These rills pare back the bluffs into a steep, subvertical face, but the rate at which they do so is controlled by the rate at which the Arikaree cover is reduced subaerially.

As the bluffs retreat in the major arcs and smaller embayments, the salients are being narrowed; next they are likely to be breached by the streams of the third order and become a line of mesas and pinnacles whose rate of destruction is progressively retarded. Hence the pinnacles have survived while a great amount of erosion has taken place in localities more favorably exposed to the action of streams. Eventually the cap is removed and the mesa worn down to a low hill or knoll and destroyed.

The rock-cut slopes that extend from the base of the bluffs to the river exist in a complementary relation to the bluffs. In the morphologic sense the bluffs are the top part of the slopes, and processes that take place at the top of the bluffs, at the contact between the Brule formation and the cap of sand stone of the Arikaree group, almost wholly determine the level at which the slopes become stable, their form, and their extensiveness, assuming no changes in the level of the river. This relationship is not reversible. Once the slopes have been formed, and as long as the bluffs exist as such, events taking place on these slopes seem to have no considerable effect on the rate of retreat of the bluffs. In other words, if the river cut deeper, the slopes would be cut down to a lower level by erosion, but the bluffs would not necessarily retreat faster.

Soon after the river had cut below the base of the Arikaree sandstones, down into the more erosible Brule formation, the larger tributary streams flowing from the south cut down into that formation along their entire lower courses. The valleys doubtless were deep and narrow. The river cut down to about its present level with certain hesitations and accelerations that may be ignored for the present. As the tributaries of the first order cut back into the upland the smaller tributaries began cutting 
lateral gullies. The valleys were widened by the retreat of the walls of the tributary valleys in the same manner as the bluffs are now retreating. As the walls retreated, the lower slopes necessarily came into existence.

Thus the divides between the streams and rills flowing from the bluffs and uplands were attacked by rainwash and rill action and by the undermining action of the widening streams and rills at grade. The divide areas of the slopes became lower until they were at grade, essentially stable. This surface in its complete form, as seen in certain localities in Scotts Bluff County, consists of gently rolling divides between broad, shallow major valleys but includes an infinitude of small waterways and divides. It slopes away from the river at a rate of 20 to 30 feet to the mile in its lower reaches and about 100 feet to the mile near the bluffs.

From the foregoing discussion of the lower slope it will be seen that it is closely allied both in form and in mode of origin to the mountain pediments of the Basin and Range region of the arid Southwest. Much of Bryan's description ${ }^{11}$ of the processes involved in the formation of the pediments in the Papago country in Arizona is similar to the description of the rock-cut slope in the North Platte Valley. The slope would be, in Bryan's usage, a pediment. In detail the processes that lead to its formation probably resemble those described by. Bradley. ${ }^{12}$

Changes in runoff change the profile of the channels of all running water that crosses the slope. The streams of such magnitude as those appearing on the topographic map are, of course, affected first and most rapidly. So readily is the Brule formation eroded that these streams attain a stable profile very quickly and thus record climatic changes that are rather slight and of short duration. Beginning with a time when the streams were in adjustment with the pediment they had helped to produce, a change that might tend to flatten their gradient would cause downcutting in the upper reaches, the gullies thus produced growing shallower down stream. The maximum downcutting would be found at the base of the bluffs, and no change would be transmitted to the upland part of the valleys although the processes of degradation might be quickened on the upland independently. Bryan ${ }^{13}$ attributes the dissection of some of the pediments in the Papago country to an increase in rainfall. A return of conditions that demand a steepening of the stream profiles would cause filling of the gullies, the greatest accumulation coinciding with the greatest cutting, that is, in the upper reaches.

Such changes in runoff, supposedly arising from climatic changes, have actually affected the streams crossing the pediment on the south side of the river, and in the light of this analysis the nature of these changes can be deduced from their effects upon the streams. After the pediment had attained a relatively stable form in the Wisconsin stage of glaciation, a slight climatic change seems to have occurred that caused the streams to cut gullies into it; they were deepest in the upper reaches and shallowest downstream, thus conforming to the postulated effects of an increase in runoff; for the time being let it be assumed that the increase in runoff arises from an increase in precipitation, together with any accompanying climatic change that would produce an equivalent effect. The gullies were then partly refilled, the greatest accumulation being in the upper

11 Bryan, Kirk, Erosion and sedimentation in the Papago country, Ariz., with a sketch of the geology: U. S. Geol. Survey Bull. 730-B, pp. 52-65, 1922 .

12 Bradley, Wilmot H., Pediments and pedestals in miniature: Jour. of Morphology, vol. 3, No. 3, pp. 244-255, 1940.

is Bryan, Kirk, Op. cit. pp. 63-65, 1922. 
reaches of the stream, and thinning downstream. However, in the lowest reaches of some of the valleys the accumulating material filled the valleys to overflowing, covered the divide areas, and merged to form an alluvial plain. South of Lyman and near Haig the plains are widely developed and probably were coextensive with a similar kind of accumulation on the flood plain of the North Platte that has since been largely removed. In Cedar Valley similar deposits accumulated as valley fill. The climate at this stage was in all probability drier than it had been when the pediment was completed and when the gullies were cut into it. Another swing toward greater rainfall, of less amplitude than the first, however, caused a partial reopening of the gullies in the headwaters, and a slight dissection of the alluvial plains in the lower reaches of these streams. The new gullying did not in all places follow the axes of the old gullies.' The streams cut entirely through the old fill, but because the valleys were not entirely full the amount of downcutting was probably less than in the previous cycle. The second cycle was completed with the advent of another period of aridity. The new gullies were partially refilled, and the alluvial plains and the valley fill in Cedar Valley may again have been built up by the addition of more sediment. Still another increase in humidity brought about a third and final cutting of gullies, involving the same streams in approximately the same courses. These periods of gully cutting, let it be emphasized, were definitely not caused by the changes in level of the river. Material is now accumulating in the inner trenches of these streams.

A possibility that must be discussed is that the gully cutting resulted from aridity, rather than from increased humidity as postulated above. Bryan ${ }^{14}$ showed that in the arid Southwest destruction of vegetation through overgrazing increased the runoff and lead to downcutting by streams. In Nebraska, however, the same situation did not prevail at the time of the gully cutting here described. If the sod was removed from the slopes of the North Platte Valley, and the resistance of the rock to erosion thereby reduced, the removal was caused by a decrease in rainfall. The runoff at such times seems to have been likewise reduced. In the arid Southwest, where the sod was destroyed through cultural agencies, erosion would necessarily result if the rainfall remained essentially the same. It would not follow that aridity everywhere invigorates stream erosion; on the contrary, in the North Platte Valley aridity probably paralyzed the tributary streams and made possible the filling of their gullies.

Mention has been made of badlands in the foregoing discussion. The Brule formation is particularly subject to the kind of erosion that produces this distinctive topography. It results when running water attacks material that has so little resistance that even the smallest rills cut into it, but that can retain slopes without slumping. These miniature streams soon develop characteristic profiles that depend upon the amount of water they carry. In a very soft material of uniform character the badlands stage of erosion is quickly attained and quickly passed through. Such a material is the Chadron formation, parts of which are made up of extremely soft, uniform clay and silt that slump easily. The Brule, on the other hand, is easily eroded, but is compact and limy enough to preserve the badlands for some time. Also, certain zones, or perhaps beds,

14 Bryan, Kirk, Date of channel trenching (arroyo cutting) in the arid Southwest: Seience, New Ser., vol. 62, pp. $338-344,1925$. 
are harder than others so that divides between gullies are preserved. Two characteristics of a badlands developed on the outcrop of the Brule formation result from the presence of these harder zones; the spurs between gullies find a certain longer-lived and stable position at the hard levels, so that a badlands slope looks as if it were composed of a series of minutely dissected sloping terraces, these divides being rounded ${ }^{\bullet}$ where they correspond with a hard zone, whereas elsewhere the divides are sharper. The best development of badlands in Scotts Bluff County is between the foot of Seotts Bluff and the river. An older badlands had been cut into the slope, the gullies were filled with reworked material, and a new badlands has been cut into both the Brule and the gully fill. The gullies are definitely U-shaped with precipitous walls and rather broad floors. No matter how intricate the pattern of large and small gullies, and no matter how primitive or well-advanced the stage of erosion, the interstream divides show those characteristics that have been impressed upon them by the presence of the more resistant zones.

\section{TERRACES}

The older terraces in Scotts Bluff County are remnants of slopes graded to former levels of the valley, carved chiefly by tributary streams. They slope toward the river and toward the larger tributary streams. The old contemporary river bottoms have been largely destroyed. The terraces, however, are now mantled with gravel whose thickness and field relations indicate that some of it, at least, represents major swings of the river and streams from actively erosional stages toward quiescent or even depositional ones. The two lowest terraces are not in any essential respect different from the older ones, except in their manner of preservation and in the fact that they represent minor events in the history of the valley whose record would have been obliterated had they occurred earlier. As they are now preserved they are not typical of the other terraces of the North Platte, and will be discussed separately. (Seepp.41-48.) Regarding the nomenclature of the terraces, the writers would eschew local names in favor of some numerical designation that might be valid in other regions and drainage basins, and will refer to the terraces simply as the first, second, third, etc. It is conventional to number terraces from the highest and oldest toward the youngest and lowest. However, in the area under discussion it seems preferable to begin the series with the best-preserved, lowest and youngest terrace, calling it the first. Thus it will be understood that the numerical order of the terraces is opposite to the chronological order.

\section{HUEFR TRRRACES}

No formal classification is implied in discussing the higher terraces separately. However, above the fourth terrace on the north side of the North Platte Valley are some erosion surfaces of a complicated nature, whose identity and interpretation involve much speculation. These surfaces, moreover, are preserved upon a steep, gravel-covered slope greatly dissected by stream erosion, whose appearance does not suggest its complicated history; on the contrary, the remnants of this slope, being distinctive, really constitute a unit land form shaped intermittently over a long period of time. Thus the higher terraces, in the aggregate, are a kind of unit. 
This terraced slope, when reconstructed on profiles of the land surface (fig. 4 and pl. 1), has a gradient toward the southwest of about 50 feet to the mile, and the vertical interval between the highest point on its summit and the lowest remnants is about 900 feet. It heads north of the river in a narrow ridge that is the divide between the North Platte and Niobrara river basins. The ridge trends from a high point in sec. 17, T. $26 \mathrm{~N}$., R. $55 \mathrm{~W}$., in Sioux County, toward the southeast, and loses its identity in the west-central part of T. 25 N., R. 54 W. Its altitude diminishes toward the southeast from about 5,000 feet to about 4,900 feet. This ridge is of considerable importance in the discussion of the erosional history of the North Platte, not only because in it and around it are preserved the breaks in slope that are interpreted as stream terraces representing periods of retarded downcutting, but also because it is not oriented in the direction of the modern major drainage trends but seems to parallel an early drainage pattern. The topographic profiles, drawn in a northeasterly direction (see fig. 4 and pl. 1) from the river up the slope toward the ridge, reveal 5 breaks in slope that seem to separate an equal number of dissected terraces. They will be described and the evidence leading to their identification presented.

NINTH TERRACE

The crest of the ridge mentioned above has been serrated by erosion, but enough remnants have been preserved to reveal a gravel-covered surface at an altitude of about 5,000 feet at various points in sec. T. $26 \mathrm{~N}$., R. $56 \mathrm{~W}$., but descending to 4,920 feet at the southeastern end of the ridge in sec. 19 , T. 25 N., R. $54 \mathrm{~W}$. The area occupied by remnants of the ninth terrace is wider at the northwestern than at the southeastern end where it narrows down to a point like the apex of a triangle. The gravel on it is coarse, is composed of crystalline rock and jasper from the Rocky Mountain region to the west, is unconsolidated, and altogether resembles the Pleistocene terrace gravels found at lower levels along the river. It truncates fossiliferous channel deposits of Pliocene age, which doubtless are a source of some of the terrace gravel. It is possible, therefore, that the ninth terrace represents the floor of a valley coming from the northwest, through which gravel was transported, and in which much gravel was left. It may be that the divide between the North Platte and what is now the Niobrara drainage systems was even then in existence, for little gravel is found on the northern side of the divide. During the ninthterrace stage the river seems to have stood about 950 feet above its present level.

\section{EIGHTH TERRACE}

The six profiles of the land surface, drawn from the river up the slope to the upland plain on the north, at right angles to the trend of the river and terraces, and superimposed in such a way that in all of them the river is at a common elevation (fig. 4 and pl. 1), thus show accordant remnants of the various terrace levels in terms of their elevation above the present river level. Every profile except the sixth, which is across the valley slope farthest toward the southeast, shows a terrace remnant bounded up slope and down slope by escarpments, lying at an elevation of about 900 feet above the river. In the western part of the county this 


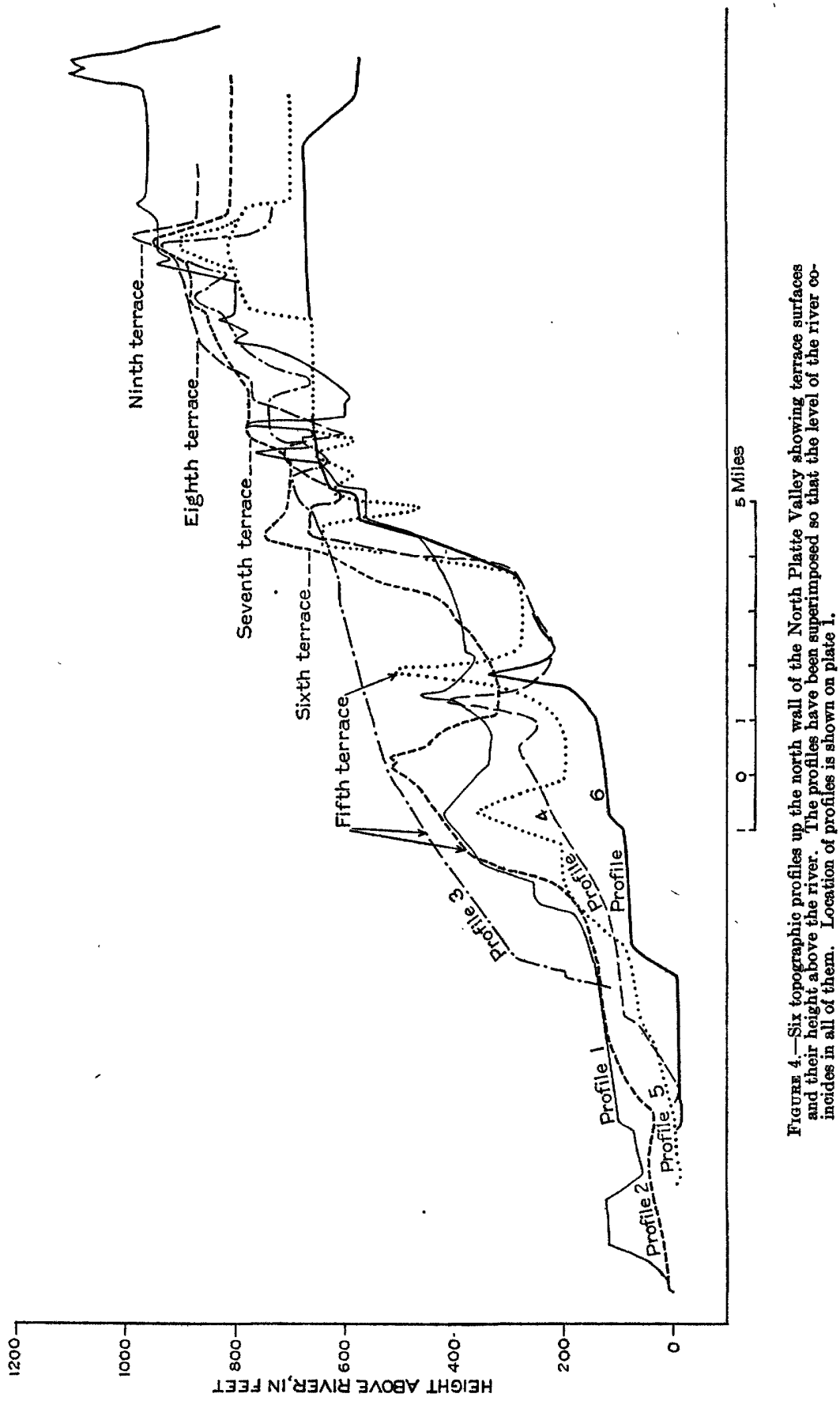


would mean an altitude of 4,900 feet above sea level, or slightly less, but at the southeasternmost point on the surface, 15 miles north of the city of Scottsbluff, it is about 4,800 feet above sea level. This surface is the eighth terrace.

North of Scottsbluff it constitutes the crest of the divide between the North Platte and Niobrara drainages, but farther west it is the first terrace below the high divide. One of the best-preserved remnants of this surface is in sec. 19, T. 25 N., R. 54 W. at an altitude of a little over 4,800 feet; and more gravel-capped remnants trail off toward the east in sections 20 and 21. In this township and in township 26 to the north, other remnants at about the same elevation can be identified in the Niobrara Valley. In fact, in the upland north of the divide numerous remnants, some small, some extensive, seem to indicate that the eighth terrace level was developed in what is now the Niobrara drainage basin, but since the two drainage basins merged at a point north of Scottsbluff in southern Sioux County, the surface was not separated from that point on to the east and southeast. During this stage the river probably stood about 850 feet above its present level.

\section{SEVENTH TERRACE}

All five profiles that intercept the terraces in the central and western parts of the area under consideration show a break in slope from the eighth terrace, and remnants of the seventh having accordant levels appear about 100 feet below the eighth. Thus the seventh terrace stands about 800 feet above the river. Since the terraces descend steplike toward the southeast along the crest of the high divide, the sixth profile, the one farthest to the southeast, does not intercept the seventh terrace.

A remnant of the seventh terrace is situated in parts of secs. 17, 18, 19, and 20 , T. 25 N., R. $55 \mathrm{~W}$., at an altitude of about 4,720 feet above sea level. In parts of secs. 3 and 11, T. 24 N., R. 54 W., this terrace occupies the divide between the North Platte and Niobrara basins. At this point it is at an altitude of 4,700 feet above sea level, but since it constitutes the divide it slopes toward the Niobrara on the north and toward the North Platte on the south.

It must be stated that profiles across the upper slopes of the south wall of the Niobrara Valley seem to encounter only a few remnants of land at the proper elevation. However, the next lower well-developed erosion surface falls at the level that is appropriate to the sixth terrace, thus leaving a sufficient interval that could accommodate the seventh terrace at its proper altitude and at its proper position with respect to the eighth and sixth levels. The remnants in secs. 3 and 11, T. 24 N., R. 54 W., do extend into the Niobrara Valley, and thus the seventh level is here considered to be a regional erosion surface and not a local one confined to the North Platte Valley. During the seventh terrace stage the river probably stood about 750 feet above its present level.

SIXTH TERRACE .

Discussion of this terrace is opened with the admission that the profiles as drawn and presented do not reveal it very well. Yet of the higher terraces so far described it is the best documented with gravel-covered slopes and remnants belonging to it. In the area 10 miles north of Morrill, on 
the east and west sides of the valley occupied by the headwaters of Dry Sheep Creek, are gravel-covered slopes and hillocks at altitudes from a little over 4,600 feet to almost 4,700 feet above sea level, and north of Scottsbluff upland remnants that lie at altitudes of 4,560 to 4,600 feet represent the sixth terrace. In the extreme northeastern corner of Scotts Bluff County and in adjoining parts of Morrill County are numerous gravel deposits at altitudes of 4,500 feet, and a little less, that rest upon this erosion surface. In this eastern locality the sixth terrace forms the crest of the divide between the North Platte and Niobrara drainage basins, and thus is seen in both drainage basins. In all parts of the area under discussion it lies about 650 feet above the river. - In the Niobrara Valley it is about the same distance below the upper levels as it is in the North Platte Valley, but its elevation above that river is less because the Niobrara has cut less deeply in subsequent erosion cycles than has the North Platte. The river at this stage probably stood about 650 feet above its present level.

FIFTH TERRACE

This terrace has been mentioned by Darton ${ }^{15}$ and named "terrace hills" by Dow. ${ }^{16}$ Remnants of it in Scotts Bluff County are small isolated hillocks which are grouped into two parallel lines, one extending across T. 23 N., R. 55 W., and T. 23 N., R. 54 W., in a direction a little west of northwest at a distance of about 5 miles north of the river and parallel to it. The remnants at the northwestern end of the line reach an altitude of about 4,280 feet above sea level, that is, about 300 feet above the river, and those at the southeastern end of the line, northeast of the city of Scottsbluff, are about 4,200 feet in altitude. They stand about 200 feet above the surrounding terrain. The hillocks in this line are rather irregular in shape, but their alignment is pronounced. The second group of hillocks is more numerous. They are alined parallel to the first group and to the river and are about 8 miles northeast of the river. They also stand about 200 feet above the surrounding terrain. As in the first group, the hillocks at the northwestern end of the line near the northern boundary of the county are highest, ranging in an orderly decline from an altitude of about 4,400 feet toward the southeast to a little less than 4,100 feet in western Morrill County. These hillocks are more regular in shape than those of the first line, and are without exception elongated in the direction of their alignment. A well-developed lowland in which younger terraces are preserved separates the two lines of hillocks. The second line of terrace remnants is separated from the upland to the northeast by another lowland on which are preserved the upper reaches of the gravelcovered slope. The escarpment which is the boundary between the lowland and the upland to the north is straight and regular in plan, and parallel to the second line of hillocks so that the intervening lowland is of uniform width. Both lines of hillocks lose themselves at their northwestern ends in a large upland area composed of comparatively undissected portions of the fifth terrace. This area is in Sioux County, 6 to 8 miles north of the town of Mitchell. These two lowlands were cut out in

15 Darton, N. H., Preliminary report on the geology and water resources of Nebraska west of the on hundred and third meridian: U. S. Geol. Survey, 19 th Ann. Rept., pt. 4, p. 740, 1899.

16 Dow, C. L., The upper North Platte Valley of Nebraska, quoted by Lugn, A. L., The Pleistocene geology of Nebr., Nebr. Geol. Survey, bull. 10, 2d Ber., pp. 168-169, 1935 . 


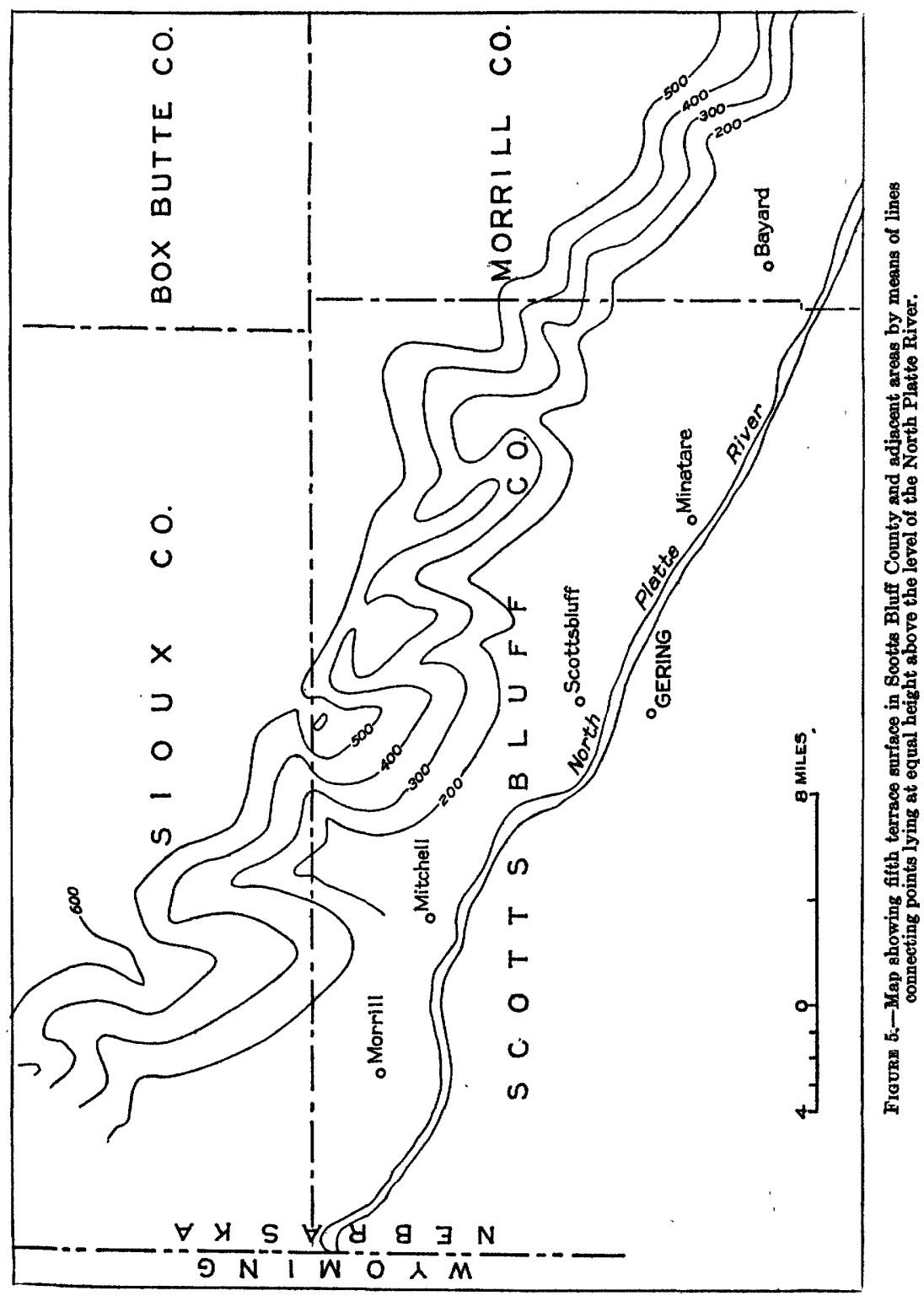


essentially their present form by streams operating in a direction parallel to the river before the fourth terrace came into existence.

The elevation at which the river flowed at that time cannot definitely be determined, but comparison of the slope at different places along the valley suggests that the river might have been at grade at a level not less than 200 feet above its present course. An initial spurt of down cutting by the river at the end of the sixth terrace stage must have been followed by a stillstand of considerable duration. What happened next was undoubtedly complicated, and the interpretation of it must account for several facts: (1) although most of the remnants of the fifth terrace are capped with gravel (hence not shaped solely by recent erosion), their summits are not all accordant with an imaginary surface of simple form; (2) the remnants in Scotts Bluff County are isolated hillocks arranged in two lines tending in a direction parallel to the river, and they are elongated roughly in the same direction; and (3) the hillocks, when viewed athwart their long dimension, typically slope off on either end from a high point on the middle, but their upper surfaces are separated from the fourth terrace by a pronounced break in slope. These facts were set forth in the above order because they seem to express a series of events in about the chronological order of their occurrence. Thus the primitive slope comprising the fifth terrace was dissected by tributary streams into a somewhat irregular surface. This continued and some of the streams began to cut valleys into the slope, which, with their interstream ridges, trended in a direction about parallel to the river. Following this (or perhaps partly contemporaneously), these interstream ridges were breached by streams eating directly back into the slope from the river, and the sloping of the tops of the hillocks in the longitudinal direction was thus produced.

In order to show relationship among the existing remnants of the fifth terrace 'this surface has been reconstructed by means of contours connecting points on the fifth terrace that stand at equal elevations above the present river level (see fig. 5). If the topography of the fifth terrace was formed in a series of stages, the reconstruction will give no suggestion of chronology. That chronology must be inferred. The shape of the hillocks was helpful in reconstructing this ancient topography.

The reconstruction of the surface indicates that early tributary valleys were cut back into the fifth terrace slope near Dry Sheep and Dry Spottedtail creeks. Other early valleys were cut back-toward the northeast from a point southeast of Spottedtail Spring, to the north of Scottsbluff near Winter Canyon, and to the northeast from a point north of Minatare. Three smaller ones also were cut back northeast of Minatare and north of Bayard in Morrill County. Most of the streams that cut these valleys seem to have had courses that were at an oblique angle to that of the river. But their headwaters curved around in such a way that they tended to align themselves parallel to the river, some cutting back toward the northwest, others even cutting back toward the southeast. The behavior of these headwater streams was noticeably restricted to places where the slope was gentlest.

The cause of the great down cutting that ended the sixth terrace stage and produced the fifth terrace surface and the significance of the down cutting in the erosional history of the region are by no means easy to understand. In the first place the profiles drawn across the greater Niobrara Valley do not show a level corresponding to the fifth terrace surface. Thus they differ from profiles drawn across the greater North 
Platte Valley. The Niobrara River flows at an altitude about 400 feet higher than the North Platte, the difference in altitude being about equal to the down cutting represented by the fifth terrace stage in the North Platte.

It is possible that the fifth and fourth terraces of the North Platte Valley may have developed without any significant change in the level of the river or in its regime, and that they are both remnants of the same terrace-forming stage. This would mean that the fourth and fifth terraces in the North Platte are contemporaneous with the fourth terrace of the Niobrara Valley. The top surface of the hillocks of the fifth terrace slopes away from certain high points, chiefly in the direction of the long axis; moreover, the remnants of the fifth terrace are separated from those of the fourth by a distinct topographic break. In many places the fourth terrace surrounds the hillocks on all sides. It is likely that the fifth terrace surface had been eroded into very nearly its present form before the end of the fourth terrace stage, and that the hillocks have been reduced very little since that time. In the Niobrara Valley, the fourth terrace, formed chiefly by the river, is confined to the inner valley and typically is preserved as spurs sloping down from the higher land but leveling off near the river. In the North Platte the postulated combined fourth and fifth terrace surface was wrought by small tributaries. This situation demands a great difference in the resistance of the Brule formation of the North Platte Valley and the Miocene sandstones of the Niobrara Valley. This is not the main consideration, however. Rather, the question is whether the fourth and fifth terraces can be assigned to the same erosional stage in conformance with any plausible process of stream erosion.

As tributary streams dissected the primitive gravel-covered slope of the fifth terrace surface, much of their energy was consumed in disposing of the gravel fill that had to be removed from the new valleys. As the steep Brule walls of the new valleys retreated, supposedly by rill action, back from the streams, their declivity probably diminished because of the accumulation of gravel on them. At the same time the dwindling upland areas yielded less gravel. Thus the streams were being fed less gravel, and after they had somewhat cleared their trenches they began to widen their valley floors. In doing so they undercut their gravelcoated valley walls. The break between the sloping top surfaces of the hillocks of the fifth terrace and the surface of the fourth terrace may have originated thus, even though no significant change in the level of the river may have taken place. It is not probable that the tributary streams deepened their valleys very much even though their load of gravel was reduced. In the headwaters valley of Dry Sheep Creek parts of the main valley floor above the immediate trench of the creek belong to the fourth terrace stage. About its periphery are several small, and a few large, remnants of the fifth terrace. Those remnants that stand nearer the axis of the valley are lower than those farther back from the axis. Moreover, the fifth terrace remnants slope in such a way that the stream at the time of the fifth terrace stage was not at a much higher elevation than it was when the fourth terrace was carved. The position of the fourth terrace surface suggests that it expanded by the retreat of the boundaries of the fifth terrace remnants, without any significant deepening of the valleys of the North Platte River and its tributaries. 
In the foregoing paragraphs the history of the outer valley of the North Platte was outlined. Erosion surfaces imprinted on the high divide between the North Platte and the Niobrara valleys swing downstream on the North Platte side around the southeastern end of the high divide and back upstream on the Niobrara side. These erosion surfaces are identified in profiles of the topography. Some consideration need now be given to the nature of the evidence that the surfaces are correctly identified, and that they truly represent stages in the episodal erosion of this part of the Great Plains.

Figure 4, already referred to, consists of six profiles drawn from the river up the north slope of the North Platte Valley to the high divide. In all the profiles the river has been plotted at the same level. No special care was taken in selecting the profiles; many more were drawn than are presented here, and they all showed the same character, except as recent erosion may have destroyed old land surfaces. Breaks in slope representing the sixth, seventh, eighth, and ninth surfaces are well enough marked in the composite profile and on the topographic map as well; but the persistence of the erosion surfaces, their orderly circumscription of the high divide, and their apparent persistence into the outer valley of the Niobrara, seem to establish their existence in reality.

The question might then be raised as to their origin. Such surfaces might be preserved on layers of exceptionally resistant rock, and thus bear no relationship to the levels at which the river stood during the erosion of the North Platte Valley. A longitudinal profile of the valley, showing the gradient of the river and the altitude of well established remnants of the higher terraces, indicates that the southeastward slope of all is essentially parallel. (See fig. 6.) On the other hand the contact between the Brule formation and the Arikaree group was plotted on the profile, and its slope toward the east was decidedly steeper than that of the river and high terraces. This should dispose of the possibility that the terraces are the result of the resistance of certain rock layers. It is therefore considered to be established that the terrace levels are true erosion surfaces, representing changes from stillstand to down cutting by the river and its tributaries. And their existence in the Niobrara Valley indicates that they are not mere local scars imprinted on the banks of a swinging river.

\section{LOWER THRAAOES}

FOURTH TERRACE

The subject of the fourth terrace has already been introduced in the discussion of the fifth. In general, the fourth exists as a sort of pedestal at the base of the fifth terrace remnants, wrapped around their base, and sloping away in all directions at a gradient of about 10 to 20 feet to the mile. It has suffered considerable dissection by streams, having in most places a less effective protective covering of gravel than the fifth surface and being older than the third terrace. It is present in the divide areas of the tributaries along the river on the north side. In this environment good examples of the fourth terrace exist in sec. $30, T .22 \mathrm{~N}$, R. 52 W.; sec. 16 and 17, T. 22 N, R. 53 W.; sec. 11, T. 22 N, R. 54 W.; 4 miles north of the city of Scottsbluff at the base of a remnant of the 
LAND FORMS

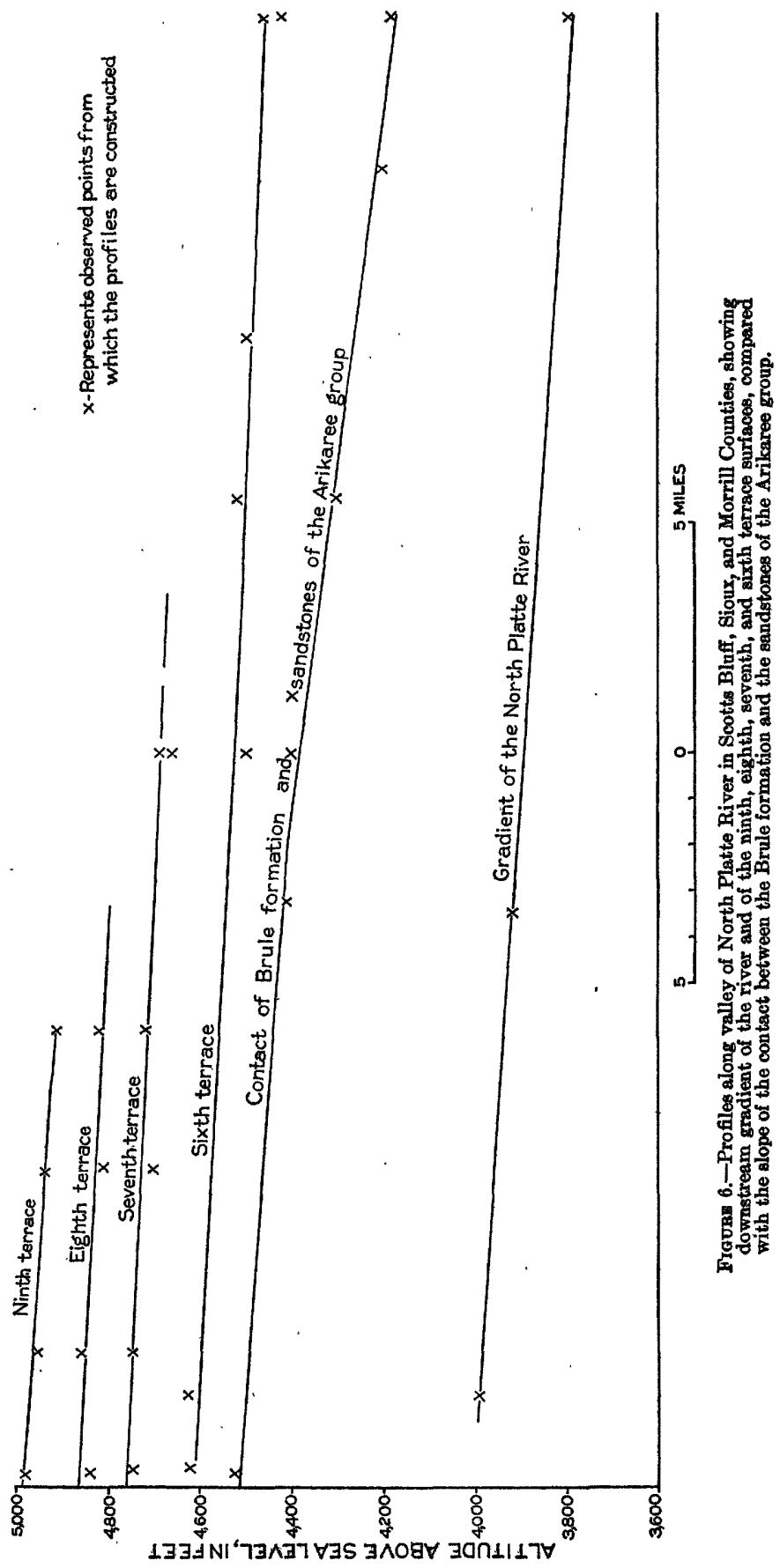


fifth terrace; and 31/2 miles north of Mitchell, on the highway to Agate. North of Scottsbluff at the State Experiment Farm its surface is underlain by about 75 feet of gravel, a greater thickness than has been found beneath the fourth terrace surface elsewhere in the area studied. From Mitchell westward it is not well preserved along the river. In the county as a whole its state of preservation is best along some of the tributary streams, but in many such places its identification becomes more difficult. The floor of the uppermost headwaters valley of Dry Sheep Creek is essentially identical with the fourth terrace surface. It can be seen on the west side of Dry Spottedtail Creek north of Mitchell, as a nick on the valley wall covered with gravel.

In the area on the east side of Lake Minatare the relation of the fourth terrace is complicated. It lies at an altitude of about 4,160 feet at the eastern end of the lake, but in the drainage area of Ninemile Creek a little farther eastward the terrace was developed at a lower elevation, and remnants of it lie at about 4,080 feet above sea level. From certain vantage points both levels of it can actually be seen at once.

The fourth terrace stands 250 feet or more above the river. The corresponding terrace in the Niobrara Valley stands from 200 to 250 feet above river level. If the North Platte River eroded its valley deeper between the fifth and fourth stages than did the Niobrara, the difference could not have been over 100 feet. However, since the terrace was cut by the Niobrara River on rather resistent rock, and since it was developed into a rather broad lowland by small tributaries of the North Platte, the fourth terrace stage seems to represent a long and important episode in the erosion of the valleys in the part of the Great Plains now being discussed. During this time the river was probably at a grade about 200 feet above its present level.

\section{THIRD TERRACE}

This terrace is conspicuous and well preserved on the north side of the river. On it are situated some of the most productive farm lands in the county. It stands 80 to 100 feet above the river, is from 3 to 4 miles wide, and slopes toward the river at an average, but not uniform, rate of about 20 feet to the mile. Near the river, however, its slope is much less. Essentially, it is a bench cut upon the Brule formation by tributary streams, covered with a mantle of gravel that is not over 10 to 20 feet thick in most places. On the south side of the river, where gravel for a protective cover was not available to the streams, it has been nearly destroyed by erosion. Although it is most conspicuous along the river, it follows the tributary streams up into their headwater areas. Along both branches of Sheep and Spottedtail Creeks and along Winter and Ninemile Creeks it appears as a narrow terrace generally 50 or 60 feet above the level of these creeks in the downstream reaches, but less upstream. It also follows some of the small unnamed creeks, most of them ephemeral or inactive during the present erosional cycle, back into the lowland between hillocks of the fifth terrace, as in the area 6 miles north - of Scottsbluff.

On the south side of the river the terrace has been preserved in only a few localities, and even there its identification is not certain. On the north side of Cedar Valley the interstream spurs suggest a poor preservation of terrace surfaces, one of which may be the third. Southeast of 
Lyman, in sec. 19 , T. $22 \mathrm{~N}$, R. $57 \mathrm{~W}$, a hill whose crest stands at an altitude of about 4,200 feet carries a scattering of terrace gravel and is thought to be a remnant of the third terrace.

The surface of the third terrace in many places does not slope in a simple, regular fashion toward the river; channels a few hundred feet to a mile wide run along it as shallow sags and give the terrace the appearance of being double. The northern margin of the sags is easy to see, for it is a more or less distinct scarp a few feet high. The sags mark the site of gravel-filled channels that issue from tributary valleys and cross the terrace at an oblique angle to the trend of the terrace and river. On that part of the third terrace lying west of Scottsbluff, drilled wells have encountered as much as $\mathbf{1 0 0}$ feet of coarse water-bearing sand and gravel in the channels. Outside the channels the surface of the Brule would generally be encountered within a dozen feet. Thus at one time during the third terrace stage the tributary streams from the north cut channels deep into the surface of the terrace and later filled them with sand and gravel. A deep gravel-filled channel also underlies the present river and its inner valley, having a maximum depth of about 200 feet below present ground surface and about 300 feet below adjacent parts of the third terrace. This channel is nearly everywhere narrow, and somewhat straighter than the river at present. Its sides are steep. Many wells that have been drilled into this deposit of sand and gravel yield large supplies of water. The channels are shown on pl. 1 by a contour of the bedrock surface.

It might be difficult to correlate the filled channels in the terrace with the channel beneath the inner valley, were it not for certain field relations which show that they were contemporaneous. The field relations indicate that the deep channel under the river passes beneath the third terrace at a point 2 to 3 miles east of the city of Scottsbluff and continues under it from there out of the county, to the southeast. The evidence indicates that the deep channel splits east of Minatare, one part lying under the inner valley and the other part lying under the third terrace. It enters the terrace at the eastside of Winter Canyon, seemingly from the west, and from that point swings back farther toward the north away from the riverward margin of the terrace; it then continues in a direction parallel to the trend of the terrace and the river, to the eastern border of the county. Where the terrace margin intercepts a gravel-filled channel it is likely to be very irregular, with a characteristic hummocky topography which is of great aid in tracing the channels. In the valley of Winter Creek the third terrace is double, having one level about 30 feet above the creek bed and another about 45 feet above it. This double terrace apparently is unique in the streams of the area. Its upper surface is coextensive with the remnants of the third terrace in the main valley, and its lower surface along Winter Creek is coextensive with the top of the fill in the channel cut by the river into the third terrace surface. This evidence seems to establish the conclusion that the channels cut and filled by tributary streams, and that cut and filled by the river, are contemporaneous. Since they certainly were cut and refilled before the final dissection of the third terrace, they should be regarded either as a separate stage or a substage of the third terrace. In this report the channel surfaces are called the $3 \mathrm{a}$ terrace, and the stage of erosion when the channels were cut is called the 3a 
stage. However, unless otherwise specified, reference to the third terrace or stage will include the $3 a$ terrace or stage.

The contour map of the bedrock surface in the inner valley of the North Platte, including the third terrace surface (pl. 1), was based partly on field observations but chiefly on data furnished by the logs of test holes and wells. This map, although of necessity generalized, shows the location and the approximate depth of the 3a channels. Certain facts are revealed by the bedrock contour map, which, when considered together, lead to some rather important conclusions. The tributary channels beneath the third terrace are shallow near the point where they debouch from the upland, but attain a maximum depth of about 100 feet nearer the terrace margin; the channel beneath the river is about 200 feet deep below the modern flood plain along its whole extent in the county. Some of the tributary channels are relatively wide with respect to their depth, whereas the deepest part of the channel of the river is deep and narrow, not more than 3 miles wide. The sides of the tributary channels seem, in places at least, to be less precipitous and gorgelike than those of the river channel. The contours indicate that the tributary channels were not graded to the bottom of the river channel but to a level about 150 feet above it. North of Henry the tributary channel seems to indicate that the stream ancestral to Sheep Creek swung around, widening its channel, and even cutting new ones and deserting the old, suggesting that it, and presumably the other tributary streams, were long at grade.

The facts enumerated above seem to add up to the following interpretation of conditions at the time of the channel cutting. The river began cutting a channel into the Brule and in so doing compelled the tributary streams likewise to cut channels. But after it had cut down approximately 150 feet below the level of the third terrace it reached grade. Here it seems to have remained in equilibrium for a rather long time. The tributary streams north of the river cut channels to a depth conformable with the level of the river and proceeded to widen them to the dimensions they have today, where they are preserved beneath the third terrace. It is not clear what the tributary streams south of the river did during this interval. It seems, however, that the third terrace was almost completely destroyed, and the pediment now seen along the southern side of the valley was brought into being at this time. The pediment was very extensive, for it includes the post-third terrace level of Cedar Valley and the Lyman plain.

After this stillstand, if this order of events is correctly stated; the river quickly cut down again and excavated the deepest part of the channel; then quickly refilled it to a level only 40 to 60 feet below the level it occupied during the third terrace stage, before any channels were cut. The tributary streams seem not to have cut down their chaninels very much in response to this deepening, but must have aggraded as the river refilled its channel.

Or something like the reverse may have happened. If the deep channel of the river was cut quickly to its maximum depth, the tributary streams might have lagged considerably in their down cutting. Then if the river channel was filled with about 150 to 200 feet of alluvium, and the river rested at grade at that level for some time, the tributary channels might have attained their present relation to the trunk channel. The channels cut by the tributary streams north of the river, and the pedi- 
ment on the south side of the river, would thus be younger than the deepest part of the channel cut by the river.

The surface of the filled channels, the 3a surface, lies from 20 to 50 feet below the third terrace surface in the tributary channels, but in the main river it is more likely that the $3 a$ surface was from 40 to 60 feet below the third terrace surface.

\section{AGE OF THE PEDIMENT SOUTH OF THE RIVER}

The opinion has been expressed in the previous discussion that the pediment south of the river, including Cedar Valley and the surface of the Lyman plain, attained essentially its present form while the river stood at grade at about the level of the floor of the tributary $3 \mathrm{a}$ channels where they intersect the channel beneath the river. The age of the pediment is important, especially when events in the North Platte Valley are compared with events in other valleys in Nebraska in order to establish a common Quaternary chronology. There are some reasons for reaching a tentative conclusion as to the age of the pediment.

The pediment could conceivably have been developed in essentially its present form while the $3 \mathrm{a}$ channels were being cut by the tributaries north of the river during an inferred stillstand, when the river stood about midway between its position before it began cutting its $3 a$ channel and the deepest level it reached during the channel-cutting; or after the channels had been filled, and the $3 \mathrm{a}$ stage had been ended by down cutting of the river and streams to a new level. If the pediment had been developed during the first time suggested, it would be contemporaneous with the 3a channels of the northern tributaries; if it had been formed during the second time suggested, it would be nearly contemporaneous with the valleys these streams cut into the third terrace surface north of the river at the end of the 3a stage.

The pediment is an extensive feature and represents the removal of much material since the destruction of the third terrace from the south side of the river. The $3 \mathrm{a}$ channels cut by streams into the third terrace are much larger than the modern valleys of the same streams, and if this comparison means anything, it suggests that the pediment was formed during the $3 a$ stage.

Where the slope of the pediment is fairly gentle, the level at which it intercepts the $3 a$ channel beneath the flood plain is rather near the level at which tributary $3 a$ channels from the north intercept the main channel-a relationship that suggests that the pediment and tributary $3 a$ channels are contemporaneous.

After the development of the pediment the streams crossing it cut the gullies in which the fill of the second terrace stage was soon to be deposited. Likewise the third and 3a surfaces were trenched by the river and tributaries from the north. The river cut to a level somewhat below its present grade, and the northern tributaries also cut below their present grade. But the tributaries south of the river are of special interest because their down cutting was very evidently a response to an increase in runoff, probably relating to an increase in precipitation, as indicated in a previous analysis.

\section{SECOND TERRACE}

The two lower. terraces, the second and the first, are in several important respects different from the older and higher ones. They are 
minor features in the topographic complex of the area; they obviously record events in the erosional history of the North Platte Valley that are distinctly minor, and they are primarily depositional features, whereas the upper terraces, except the 3a, are essentially land surfaces planed by stream erosion with sprinklings of gravel left on them. Because cultural remains have been found in the two lower terraces, the problems of their age relates to the geologic age of early man in North America.

The second terrace is poorly preserved along the North Platte River. Along the face of the third terrace of Scottsbluff it can be seen as a bench 30 to 40 feet above the river, ranging in width from a few hundred feet directly north to perhaps a quarter of a mile northwest of the city. The terrace there is an extension of the undissected second terrace surface that forms the floor of a pair of unnamed valleys entering the inner valley of the river at a point about 3 miles northwest of Scottsbluff. One of these valleys extends about 5 miles to the north back from the edge of the inner valley of the river and is now filled with fine-grained sediments.

Test holes show that at two places in sec. 19, T. 23 N., R. 55 W., the fill is 35 to 40 feet thick, and a well drilled on the second terrace north of Scottsbluff reached the Brule formation at a depth of 40 feet. This indicates that the river cut to at least about the same level as its present one in the interval between the third and second terrace stages, and that at least some of the tributary streams cut to a level about 40 feet below the present surface of the second terrace in their valleys. This down cutting by tributaries north of the river was probably accomplished largely at the time of the'gully cutting south of the river. South of Mitchell, about half a mile beyond the river, is a small remnant of the second terrace through which the highway has been cut. Fine gravel is exposed on the banks by the road.

Tributaries on the north side of the river have passed through the same succession of events as the river after the third terrace stage, dissecting the third terrace, partly refilling the $3 a$ trenches, and later trenching the fill and depositing the second terrace, which stands about 20 to 25 feet above these streams in their lower reaches and as little as $\mathbf{1 0}$ feet near the headwaters. The material constituting the terrace is sand and gravel mixed plentifully with silty material. At the Civilian Conservation Corps camp north of Mitchell, wells passed through 30 to 40 feet of terrace material before encountering the Brule formation; of this the upper 10 to 20 feet was described as "soil", probably material representing the first terrace which on these streams is combined with the second terrace. Poorly sorted sand and gravel in a matrix of light buff and gray silt are characteristic of the second terrace material in these streams wherever it is exposed. The second terrace has been more greatly eroded in the lower reaches of these streams and therefore is best preserved in the upstream parts of their basins.

It is in the tributary streams south of the river that the second terrace is preserved in a manner typical of other areas where it has been studied. Here the pediment was probably developed during the 3a terrace stage, and the chief streams that crossed it became stable, or graded, within wide shallow valleys. Then they excavated gullies, as previously shown, and for a time carried silt, sand, and gravel of Brule pebbles and fragments of concretionary sandstone from the Arikaree. This material accumulated as a more or less transitory fill. The gully cutting was the 
flattening of their gradient by streams in response to an increase in runoff, and the fill was the normal channel deposit of these streams. After a rather short time the runoff was diminished, probably because of a climatic swing toward greater aridity, and fine buff-and-grayish sandy silt almost filled the gullies and covered the coarser deposits. This fill was deposited partly by wind, if its lack of structures suggesting water deposition is a criterion, and partly by water. It is the kind of material that even today is washed from surfaces of the Brule formation by rills and blown by wind. Much of it was probably washed down the sides of the gullies from above its resting place, although some of it represents the kind of sediment that the enfeebled streams were capable of carrying. One or more dark, limy soil zones 1 foot or less in thickness characteristically runs through this fine-grained part of the terrace deposit. Near the headwaters of the streams the depth of the fill is as much as 30 feet, and in the lower reaches, where the gullies are shallow and wider, the fill is as little as 3 or 4 feet thick. Kiowa and Owl Creeks, the unnamed north-flowing streams in the area south of Mitchell, the streams emptying into Cedar Valley, including Cedar Creek, and others farther east all contain fill, now trenched, that makes up the second terrace.

The gullies that were cut into the Brule slope disappear in the lower reaches of the streams, and although the fill representing the second terrace grows thinner downstream it overruns the gullies, spreads out, and forms thin subaerial deltas, or as in Cedar Valley, a valley fill. This has happened chiefly in three places, in the lowland south of Lyman, in that lowland, called Mitchell Bottom, along the south side of the river near Haig, and in Cedar Valley. This deposit south of Lyman and in Mitchell Bottom is on the average about 20 feet thick, but in Cedar Valley it is from 35 to 45 feet thick. However, the whole of the deposit was not laid down during the second terrace stage. The material forming the upper part of it is thought to belong to the first terrace stage. Thus normally the surface of the first terrace lies at a lower level than that of the second, but in these alluvial plains the material of the first terrace overlies that of the second in a normal stratigraphic manner. The sediment in the alluvial plains resembles the material in the respective terraces upstream, being a loose silt with thin, erratically distributed lenses of ill-sorted sand. It has a tendency to flake off where exposed to the air and to form steep or vertical banks.

Perhaps the most significant fact about the second terrace is the presence in it of man-made flint implements, of the Yuma type. They are believed to be somewhat closely related chronologically to the Folsom flints. Yuma implements have been recovered at many localities in western Nebraska, chiefly by members of the staff of the Nebraska State Museum. One of the first and most significant finds was in a small tributary of Kiowa Creek a few hundred yards northeast of Signal Butte, in sec. 11; T. 21 N., R. $57 \mathrm{~W}$. A flint javelin point was associated with bones of an extinct type of bison ${ }^{17}$. There the finds were in the gravel at the base of the terrace deposit, which is overlain by about 15 feet of the structureless silt typical of the second terrace deposits in most of

17 Barbour, E. H., and Schultz, C. B., Paleontologic and geologic consideration of early man in Nebraska. Nebraska State Mus. Bull. 45, pp. 431-449, University of Nebraska, April, 1936. Barbour, E. H,, and Schultz, C. B., Pleistocene and postglacial mammals of Nebraska: Early Man, pp. 185-192, Lippincott, New York and Philadelphia, 1937. Lugn, A. L. The Pleistocene geology of Nebraska: Nebraska Geol. Survey, Bull. 10, 2d ser., pp. 183-188, 1935. Macclintock, Paul, Barbour, E. H., Schultz, C. B., and Lugn, A. L., A Pleistocene lake in the White River Valley: Am. Naturalist, vol. 70, pp. 346-360, 1936. 
the streams south of the river. Snail shells are numerous in this upper material, and according to F. C. Baker whose discussion is quoted in Lugn's paper, more land types and fewer aquatic types are found in the upper part of the depasit. Other Yuma points have been taken from the second terrace in the drainage basin of the White River in Sioux and Dawes counties and in South Dakota. The artifacts come mostly or entirely from the lower zones of the deposit but not necessarily from the basal gravel; some occur in dark soil zones within the massive silt. Hearths have been found in soil zones.

The second terrace in the basin of the White River contains laminated silt with layers of clay or pollen between. The laminations come mostly in the lower portions of the deposit. They may occupy channels cut into massive silt and may be overlain by more massive silt. These laminations were called varves by MacClintock and his co-authors in the paper referred to above, and on that basis the terrace deposit was considered Wisconsin in age. Examination of the laminations fails to support the contention that they are varves, and hence the existence of laminated silts cannot provide any clue as to the age of the deposit. They probably do represent deposition in still or sluggish water, but this fact does not necessarily lead to the interpretation offered by MacClintock. If the lamination of the terrace deposit in the White River basin truly represents lacustrine deposition, then some kind of local ponding may have occurred in the valley of the White River.

Any conclusion as to the age of the second terrace, however tentative, must depend in part on an appraisal of indefinite evidence. In the first place the second terrace is a small feature, and the erosion that preceded its deposition produced comparatively small features. The river probably cut to about its present level or a little below it from its $3 a$ level. The physical events that led to the erosion and deposition of the second terrace stage were doubtless of minor potency and of brief duration.

The climatic significance of the gully cutting and subsequent refilling that took place on the pediment south of the river must again be referred to. If the gullies were cut by streams activated by increased runoff and, as it is held, increased precipitation, then this climatic change must also have been a minor one. Such an increase in precipitation might well be expected to correspond with a minor advance of waning glaciers in the mountains to the west and also in the central lowlands of the United States. Likewise, the fill, which is taken to indicate a climatic swing toward aridity, must record a brief climatic reaction of small amplitude. These features, small and ephemeral, must have been recent to have been preserved. The second terrace has been nearly destroyed in the main valley of the North Platte but is still preserved in the small valleys and gullies of its tributaries. Hence, the problem of correlating the second stage with some widespread occurrence that corresponds with the conditions believed to have attended it in the North Platte Valley narrows down to an examination of the latest Pleistocene or early Recent divisions of geologic time.

It is believed that the choice of times to which the second terrace stage can best be assigned is limited to two; the last substage of the Wisconsin or the next to the last substage. The earlier possible time will be discussed first. 
In their valuable and comprehensive study of the Lindenmeier site in northeastern Colorado, Bryan and Ray ${ }^{18}$ traced the Lindenmeier Folsom culture layer down to the South Platte Valley, where it was correlated with the Kersey terrace, which is the second terrace above the flood plain. It stands about 20 to 45 feet above the level of the river. Below it is the Kuner terrace, standing about 12 to 20 feet above the level of the river. There is at least one higher terrace, and it seems to be a complex one. The terraces of the South Platte Valley were traced up the canyon of the Cache la Poudre River and tied in with moraines in the mountains. The Kersey terrace was correlated with the Corral Creek moraine, named by Ray, and the Kuner terrace was correlated with the younger Long Draw moraine. Two moraines older than the Corral Creek moraine were recognized. The moraines in the Cache la Poudre canyon were then correlated with the continental glacial stages and substages of the American Middle West and East and of Europe. The Corral Creek moraine was considered to represent the next to last substage of the Wisconsin, or Mankato, of the central United States and the Pomeranian of Europe. Thus the age of the Corral Creek moraine, the Kersey terrace, and the Lindenmeier culture layer was concluded to be about 25,000 years.

Certainly the assemblage of lower terraces in the North Platte is very similar to that in the South Platte Valley. The possibility of their being contemporaneous seems considerable. It is true that the cutting of channels in the Colorado area is considered by Bryan and Ray to result from aridity, and filling is thought to result from increase in moisture, whereas quite the opposite interpretation was reached in the North Platte Valley, but this difference may be, in part at least, because of a lack of precision in stating the case.

Nevertheless, a later date probably should be considered for the second terrace in the North Platte Valley. Part of the reason for thinking so arises from an examination of its relation to the first terrace, which will be taken up in the discussion of that terrace. If the later date is tentatively adopted, then it is probable that the erosion that preceded the deposition of the fill of the second terrace stage took place during the last substage of the Wisconsin, and the filling of the channels then produced went on in early postglacial time. If the deposition of the Yuma artifacts in the second terrace was early in the stage, then these artifacts, at least in Scotts Bluff County, must be about 10,000 years old. Presumably the final advance of the Wisconsin ice in the mountains of eastern Colorado is marked by the Long Draw moraine. The fill in the valleys and gullies of the North Platte Valley area would then, if the assumed dating is correct, have accumulated during an interval approximately from 10,000 to 7,000 years ago.

Subject to this qualification, then, it appears either that the second terrace of the North Platte Valley is more closely associated with the Kuner terrace of the South Platte, or that the second terrace is contemporaneous with the Kersey terrace, which should have been correlated with a younger glacial advance; if the moraines of the Cache la Poudre are properly dated, that advance would be represented by the Long Draw moraine. The case for the later date of the second terrace

18 Bryan, Kirk, and Ray, L. L., Geologie antiquity of the Lindenmeier site in Colorado: Smithsonian Misc. Coll., vol. 99, No. 2, $76 \mathrm{pp}, 1$ 1940. Ray, L. L., Subdivision of the last glacial stage in the southern Rocky Mountains: Geol. Soc. America, Bull., vol. 50, No. 12, 1939. 
will be resumed in conjunction with the description of the first terrace.

Barbour and Schultz, and Lugn ${ }^{19}$ mention the so-called Citellus zone as a possible source of Yuma artifacts. The Citellus zone, where it can be correctly identified, lies between the Loveland and Peorian loess sheets. In the sand hills region, at unspecified sites, Yuma artifacts are said to have been recovered from blowouts, near which dark soil has in some cases been detected; but in no case do artifacts seem to have been recovered from one of the soil zones. These circumstances have led Barbour and Schultz, and Lugn to state that the men who made the artifacts may have inhabited Nebraska at some time between Sangamon and early Peorian time. This improbable contention awaits proof that the artifacts came from a soil zone, and if so, that the soil zone is the same as that which occurs between the Loveland and Peorian loess sheets. Buried soils are common in Nebraska in deposits of middle and late Pleistocene, and Recent age.

\section{FIRST TERRACE}

Following a slight resurgence of erosive activity, the river cut into the second terrace to a depth of about 40 feet. The tributaries on the north side of the river may also have trenched their fills, but less deeply. The gullies on the south side of the river were reopened when the streams cut about 20 feet into the second terrace fill. The new gullies, like the older ones, were deeper in the headwaters and diminishing near the lower reaches, down to a point where no deepening took place at all. This sort of deepening, as was shown above, probably resulted from an increase in runoff following upon a probable increase in rainfall. After this brief period of erosion, the river and streams again began aggrading. The deposition was probably caused by a decrease in rainfall.

In the main valley the North Platte River cut down through the second terrace to a depth of from 30 to 40 or more feet. It then widened its trench to about the present dimension, destroying most of the remnants of the second terrace. On the valley floor along the north side of the river, sediment began to accumulate, ranging in size of grain from fine gravel to silt, the latter conspicuously in evidence. This deposit is the first terrace and stands from 10 to 15 feet above the present flood plain. It is not a prominent feature of the topography, in many places scarcely being distinguishable. At the point where the larger tributaries from the north emerge on the valley floor, the terrace is well developed and, on examination, proves to be a series of alluvial fans truncated on the riverward side by the present channel of the river. At a point $11 / 2$ miles west of Mitchell the terrace stands about 15 feet above the river flood plain, and a few exposures show that it is made up of some fine gravel and sand but more abundantly of silt. It is evident that the fans were constructed during a time when the river was unable to clear the obstructing debris from its valley, whereas more recently it has truncated these fans. In the stretches of the valley between the fans the material seems to have been derived from wash from the valley sides, probably from the load of the tributaries after they had passed over their fans, and from the load of the river in flood.

\footnotetext{
19Barbour, E. H. and Schultz, C. B., Paleontologic and geologic consideration of early man in Nebraska: Nebraska State Mus. Bull. 45, p. 45, 1936. Lugn, A. L., The Pleistocene geology of Nebraska: Nebraska Geol. Survey Bull. 10, 2 d ser., pp. 143-145, 1935.
} 
The first terrace is not conspicuously preserved along the south side of the river.

The Lyman alluvial plain extends a short distance to the north of the town, and in sec. 22 , T. 23 N., R. 58 W., it ends in terrace face where the river truncated it. Here the surface of the terrace stands about 15 feet above the flood plain of the river, and in an exposure along the road about 10 feet of light gray silt, somewhat darkened by carbonaceous matter scattered through it, rests on sediments of the White River group. This terrace deposit shows bedding. At the top is a 3-foot layer of dark, wind-blown sandy silt of more recent age. To the south the sediment corresponding to the second terrace is overlain by a few feet of material thought to belong to the first terrace stage. The upper material is made darker in color by a more abundant admixture of carbonaceous matter.

The alluvial plain in Mitchell Bottom was also truncated by the river, but the terrace face is not so prominent as that north of Lyman. No stream has cut a deep channel through this plain since the first terrace stage. Those streams that cut gullies near the bluffs, at the upper or southern end, have practically no channels where they reach the riverward edge of the plain.

At the mouth of Cedar Valley, in the vicinity of Gering, the valley fill belonging to the second and first terrace stages has been truncated by former subsidiary, high-stage channels of the river, which pass to the south of the city. The terrace edge is not prominent but shows up fairly well on the contour map. Although the first terrace stage was terminated by gullying along the edges of the valley near the bluffs, the fill near the valley axis was not trenched. In Cedar Valley the sediment believed to represent the first terrace stage contains soil zones of dark carbonaceous matter and, although similar to the sediment of the second terrace, is darker than the older material.

In the gullies south of the North Platte River, as in the alluvial plains, this sediment of the first terrace stage is similar to that of the second but is darker with carbonaceous matter, and contains one or two, or even mare, prominent black soil zones. In Scotts Bluff County the first terrace in the gullies south of the river is obscure. C. B. Schultz, of the Nebraska State Museum, University of Nebraska, pointed out these imperfectly illustrated relations, and the writer then studied the second and first terraces in the White River Valley, where the preservation of both is excellent. Figure 7 shows the ideal relationship of the first and second terrace fills in the gullies south of the North Platte River.

Hearths, flint implements, and pottery shards found in abundance in the first terrace sediments testify to the existence of men in the region at that time. These inhabitants left a much more diverse culture than did those who left the Yuma flint points. This culture is thought to be similar in a general way to that found in the lower culture zones at Signal Butte. It evidently is of no antiquity, and the few thousand years interval since the time of the completion of the first terrace stage would not be inconsistent with the probable age of the cultural remains found in it.

With a cultural content that indicates a comparatively late postglacial age, the first terrace may be fitted into supposed events that took place within the past few thousand years. The warm, dry period thought to have accompanied the deposition of the upper silty beds in the second terrace deposit 10,000 to 7,000 years ago was probably broken by a brief 


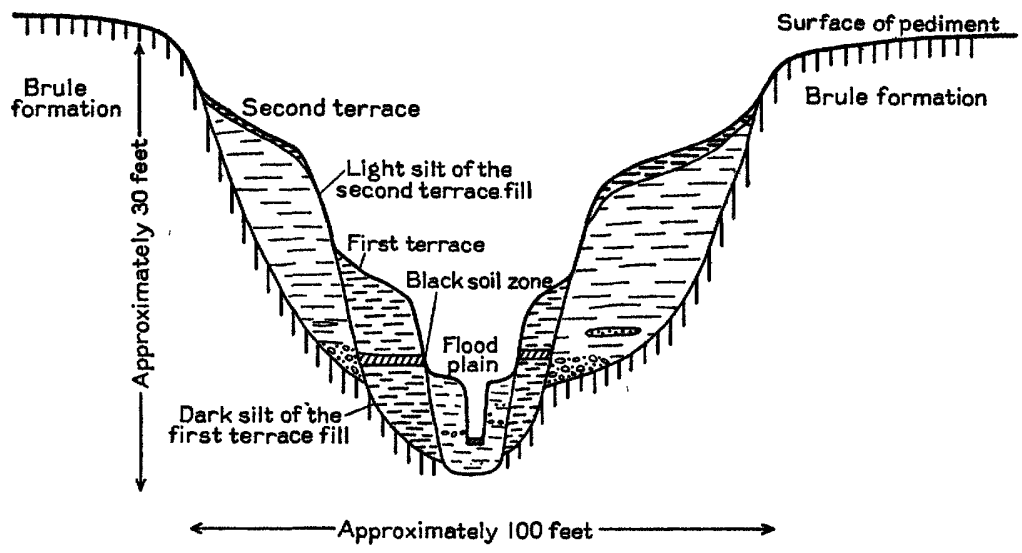

Figure 7.-Ideal cross section of a tributary valley south of the North Platte River showing the relation of the first and second terraces to surface of the rock-cut slope.

interlude of warm but wetter climate, probably prevailing during the interval 7,000 to 5,000 years ago. The increased runoff resulting from it probably caused the trenching of the second terrace deposit by the river, the tributaries north of it, and the streams crossing the pediment on the south side of the valley. From about 5,000 to 3,000 or 4,000 years ago a warm dry climate seems to have prevailed. The fill of the first terrace stage built up within the trench of the river, the valleys north of it, and within the gullies south of the river. Since the advent of the modern cool, moist climate 3,000 to 4,000 years ago, the streams and river have been cutting away the first terrace.

Thus, the second and first terraces, so similar in kind and magnitude, probably were developed under similar conditions in latest Wisconsin and postglacial times.

The series of events recorded since the third and 3a stages in the North Platte Valley and the climatic conditions inferred from the events appear in tabular form below. With it are listed the climatic changes listed by Auer ${ }^{20}$, with the supposed intervals expressed in years from the present time, based upon European chronologies.

\section{Sequence of late Quaternary events and climate as inferred in the North Platte Valley}

\begin{tabular}{|c|c|c|c|}
\hline \multirow{2}{*}{ Erosion and deposition } & \multicolumn{2}{|c|}{ Climate inferred- } & \multirow{2}{*}{$\begin{array}{c}\text { Age of } \\
\text { Europeean } \\
\text { climatic changes, } \\
\text { in years before } \\
\text { the preeent }\end{array}$} \\
\hline & From terraces & $\begin{array}{c}\text { From Canadian } \\
\text { peat boge }\end{array}$ & \\
\hline $\begin{array}{l}\text { Erosion. } \\
\text { Deposition of second terrace. } \\
\text { Erosion... } \\
\text { Deposition of first terrace. } \\
\text { Erosion. }\end{array}$ & $\begin{array}{l}\text { Wet (latest glacial advance?). } \\
\text { Dry... } \\
\text { Wet. } \\
\text { Dry. } \\
\text { Wet. }\end{array}$ & $\begin{array}{l}\text { Warm and dry } \\
\text { Warm and moist. } \\
\text { Warm and dry } \\
\text { Cool and moist.......... }\end{array}$ & $\begin{array}{l}10,000+ \\
10,000-7,000 \\
7,000-\$, 000 \\
5,000-3,000 \\
3,000 \text { to present. }\end{array}$ \\
\hline
\end{tabular}

\section{SUMMARY OF STREAM PROCESSES}

Most of the stream activity, as it now can be seen in operation and as the shape of the land surface shows it to have been in the recent past, is

20 Auer, Vaino, Peat boge in southeastern Canada: Canadian Dept. of Mines, Mem. 162, 32 pp., 1930. 
confined to the part of the valley that is underlain chiefly by the Brule formation. This condition leads to some rather uncommon stream processes, because the Brule is a formation of exceptionally uniform grain size, that is, silt, and it is extremely subject to erosion by running water. A few unusual characteristics of stream erosion are worth mentioning.

One of the most spectacular characteristics of streams in the area is the rapidity and ease with which down cutting is accomplished, even by small units of running water. At the foot of the north face of Scotts Bluff, west of Gering, badlands topography has been etched on a sloping tract of land occupying a space between the foot of the bluff and the flood plain of the river. It is no more than one-third mile long. The gradient of the land is steep, but a maze of gullies has been cut partly into the Brule formation; each gully must have been excavated by a small stream. Artificial water-courses, like the overflow from the Highline canal into Lake Minatare, have within a few years eroded deep gullies. The gullies have in common nearly vertical walls and a flat floor, whose width would about equal that of an efficient conduit for the amount of flood water that would periodically pour through it. These walls are scarred with deep, narrow clefts cut by small streamlets from the sides, which have been able to grade themselves to the bottom of the gullies.

A comparison of young watercourses with successively older ones yields evidence that few of the streams widen their valleys to any considerable extent. The topography of old land surfaces developed on the Brule is not of the kind that would be produced by valley growth through undercutting of the walls, nor is there in Scotts Bluff County evidence that lateral planation by meandering is an important process. In fact most of the meanders are found where the streams are flowing on alluvial fill. Older water courses in general have broadened their drainage basins as their valley walls were planed down to gentler slopes. Thus the discharge of the streams was increased, and their channels were widened to accommodate the greater discharge. This process seems to be dominant in the widening of the tributary valleys. The degradation of the walls of the tributary valleys, is accomplished by the down cutting of streamlets and rills.

Another fact to be noted is that the tributary streams have created much of the existing topography outside the inner valley of the river. Thus, the remaining parts of the third, fourth, and fifth terraces, and perhaps some of the older ones as well, were almost wholly formed by the tributaries from the upland north of the river. The only noteworthy exception seems to be the third terrace eastward from Scottsbluff, where the river cut its channel during the $3 \mathrm{a}$ substage. These streams not only cut broad erosional surfaces, which indicate vigorous action, but they distributed over them gravel of considerable degree of coarseness. Now, by way of contrast, these same tributaries are not actively engaged, either in eroding or in transporting and depositing sediment. At the time of the second and first terrace stages they were still less active.

Evidence of the present lack of vigor of these streams is rather difficult to set forth, because it consists of numerous details that are cumulatively convincing but not individually conclusive. Among these is the disintegration of some of the streams into local ephemeral washes in their lower reaches and in their headwaters, with little or no activity in the middle reaches. One such stream is Ninemile Creek; another occupies Wild Horse Canyon, just east of Scotts Bluff County; a third can be 
seen in southern Sioux County, about north of Scottsbluff; and there are others. Wet Sheep Creek, north of Henry, has been blocked by dune sand, a fact that is not indicative of vigorous stream action. Southwest of Gering, the streams flowing from the uplands have not established a channel out of Cedar Valley to the river; after heavy rains water is said to stand there for several days. This situation suggests that the tributaries to the river in this area accomplished their erosional work under wetter climatic conditions than those at present and that they became practically inactive when the climate was drier, as during the second and first terrace stages. The state they now are in might be referred to as their climatic minimum, above which they may erode, transport, and deposit, and below which they practically cease to operate. The chief development of the third, fourth, and fifth terraces (and perhaps also the older ones) must have taken place when the climate was wetter than that at present, and probably therefore during glacial rather than interglacial epochs.

\section{WIND PROCESSES}

Wind cân operate in two ways. It can carry away or deposit material uniformly over a large area, or it can concentrate these activities. The uniformly distributed workings of wind are very difficult to recognize and evaluate, but where its activities have been concentrated, traces of these works are generally left in dune building and wind scouring. Of the uniform kind of wind work only a little can be said, for so far as is known it has left only slight traces - a blanket of loesslike material spread over the land surfaces of the area and evidence of wide-spread deflation.

\section{LOESSLIKE DEPOSIT}

This material is like loess in its mode of occurrence as a thin blanket widely distributed over the county but not necessarily in its composition. One to 4 or 5 feet of eolian material underlies nearly all land surfaces that have remained undisturbed for a long time and that are not steeply sloping. This means that the terrace surfaces, much of the lower valley slopes, and upland remnants on either side of the river are thus covered. Perhaps the fine-grained sediment covering the flood plain of the river belongs in this class of deposit. In a road cut one-quarter mile west of Lake Minatare, as well as in other places, this material thickens on the southeast side of obstructions, as if it had been deposited chiefly by winds from the northwest. Its presence on isolated hilltops proves its eolian origin. The composition of the deposit is not at all uniform, for it seems to be derived to a considerable extent from local sources. Thus, in lowlands underlain by the Brule formation, but distant from bluffs where the sandstone of the Arikaree group is exposed, the material is lighter in color and finer in grain; on the higher land surfaces, where sandstone is present, and near the bluffs, it contains more sand and is colored a dark brown by organic constituents. This kind of material covers the third terrace, the sand presumably being derived from the gravel that covers the terrace surface. It is especially thick and abundant north of Henry. In the area from Roubedeau Pass toward Signal Butte, thence westward near the county line, material of high sand content can be found near the bluffs, but it grades into a siltier type down the slopes. 
In general this deposit does not exhibit bedding planes, and its thickness is fairly uniform. Thus, it does not essentially alter the topography. However, in some localities, where it is especially thick, it grades into dune topography and is likely to be bedded. This is true in the southeastern part of the county.

\section{SAND DUNES}

Small clusters of sand dunes are numerous in Scotts Bluff County. The largest aggregation is in the southwestern part of the county, on the low divide between the North Platte and Pumpkin Creek valleys. Others are situated at the mouth of Sheep Creek west of Morrill, 3 miles south of Morrill beyond the river, in Roubedeau Pass, and in the southeastern corner of the county. About 3 miles north of Henry, in southwestern Sioux County, the dunes block the valley of Dry Sheep Creek; they are a part of a large aggregation of dunes that occupy the third terrace beyond the Wyoming State Line.

The dunes chiefly occur where recent erosion has not been going on. Two generations of dunes can be found. Old dunes are made up of sand that is dark with vegetal material, and quite probably they are contemporaneous with the loesslike mantle of silt and sand described above.

It is these old dunes that now are found on the older land surfaces where sand is abundant and where stream erosion has not recently been active. The dunes in the southwestern and the southeastern parts of the county, in Roubedeau Pass, and south of the river near Morrill are of this older generation. They seem not to have been active for a fairly long time. The dunes that have obstructed the valley of Dry Sheep Creek are more recent. The sand in them, although perhaps derived partly from older dunes or from the mantle of dark-colored eolian sand on the third terrace, is light buff in color, and practically free of any vegetal matter. To the lee of these dunes a mantle of new sand is being spread thinly over the old loesslike mantle, and where both are exposed to view the contrast in color is definite. Sage grows abundantly on sand dunes, even small ones, but not on thin mantles of wind-blown sand or on fine-grained wind deposits.

The material forming the mantle of silt and sand and the older dunes was removed from its initial resting places, transported, and deposited at a time when there was less vegetation on the land surface than now exists. When high winds are blowing, dust and sand are raised from plowed fields, and overgrazed pasture land shows some effects of deflation between hummocks of grass, but any considerable wind action must necessarily imply a sparser grass cover, and in all likelihood a more arid climate than the present one.

\section{WIND EROSION}

Although no land forms seem to have been produced exclusively by wind erosion, steep faces of loose sandstone, or sandy soil, that oppose the wind show some signs of having been etched. Little upraised, streamlined remnants may be seen where the Arikaree sandstones are exposed on the bluffs. The remnants fit snugly on the lee side of concretions that, on their windward side, protrude several inches. An exposed bluff face on which concretions are numerous is likely to show a small-scale 
striation, or etching, which has resulted from wind erosion. This striation resembles bedding. Similar results obtain when a bank of the sandy loesslike material is exposed to the wind.

When a high wind is blowing directly athwart a line of bluffs like those on the north side of Wildcat Ridge, a great quantity of sand may be seen to move up the bluffs and up the slope above the bluffs. Some of it reaches the top of the upland, and there comes to rest. This action is shown at Signal Butte, southeast of Lyman. There a dark brown silty sand, with a high organic content, has been deposited by the wind on the top of a butte made up of the Brule and Gering formations. Indian cultural remains were unearthed at three different levels showing that during the past few thousand years the top of the butte was occupied at successive intervals by human beings. Sand was blown up the north, west and east faces of the butte so as to cover the cultural remains at the end of each period of occupancy. At the time the sand was accumulating on it, the butte was growing smaller by wasting of the walls. The cultural remains were discovered because this wasting had exposed them at the edge of the butte. The cap of eolian sand is 6 to 8 feet thick, and this considerable deposit was built up within a period of perhaps 2,000 to 4,000 years. Much of the sand on other upland areas may have reached its resting place in this manner. It is still a minor process, however, and the field evidence does not suggest that the wind has been an important agent in shaping the bluffs or in controlling their rate of retreat.

\section{SUMMARY OF EROSIONAL HISTORY}

Here, in addition to a brief resume of the successive stages of erosion and stillstand by the river and its tributaries, should be included certain comments upon the age of the terraces, and upon the causes of the changes from eroding to noneroding phases undergone by the river. As to these questions no conclusive answer can be given. The age of the terraces must be determined by more, and perhaps different evidence. Whether the cause of down cutting by the river and tributaries has been uplifting of the land in the Rocky Mountains and western Great Plains or climatic changes that accompanied the waxing and waning of the Pleistocene continental glaciers, depends upon broad lines of evidence that lie outside the area studied. Further, each terrace is necessarily a problem in itself, because either a diastrophic or climatic cause could have operated to produce it.

The ninth, eighth, seventh, and sixth terraces are believed to have been formed in early Pleistocene, before and including the Yarmouth ${ }^{21}$. The question of the close time relation of the fifth and fourth terraces is very important, but apparently cannot yet be solved. They may represent the response of the tributary streams to two separate stages of down cutting by the river, or they may represent two stages in the streams' response to a single phase of down cutting by the river. The seeming absence of the fifth terrace in the Niobrara Valley would favor the second suggested possibility. In any case, the fifth and fourth terrace surfaces are believed to be respectively Illinoian and Sangamon in age, and the fourth terrace is thought to have been dissected during the

21 The dating of the hirhest terraces, and the fifth, fourth, and third terraces is based upon a correlation with events taking place in the Republican Valley, to some of which events definite dates can be aseigned. 
Iowan stage. The third terrace, with its substage of channel cutting and filling is of great importance. The cutting of a channel 300 feet below the level of the river, as it was then, and its subsequent filling certainly indicate that a change in climate had disturbed its existence. The third terrace, the 3a substage, and the pediment south of the North Platte River are considered to have been formed during the Peorian and two earlier substages of the Wisconsin. The second and first terraces, so like one another, but so different from the higher terraces, are believed to have been formed in response to minor climatic fluctuations during perhaps the last Wisconsin substage and the postglacial interval of time.

\section{GEOLOGY}

\section{GENERAL FEATURES}

In Scotts Bluff County the North Platte River and its tributaries have laid bare about 1,000 feet of sediments of Tertiary age during its period of down cutting. The formations thus magnificently exposed were studied and described by Darton ${ }^{22}$ in the late 1890 's and early 1900 's, and his work was printed in four publications of the Geological Survey, United States Department of the Interior. The information in those publications constitutes the basis of the present discussion of the geology of the area. The field study carried on during the summer and autumn of 1937 revealed no information that was not consistent with earlier findings of Darton. The present report adds a few details, the results of test drilling carried on during this investigation, and a few additional interpretations of known facts. The above statement will serve as acknowledgment of the debt to Darton's work, and further specific references to it will be omitted.

The Tertiary sediments rest upon a rough pre-Tertiary land surface whose relief was imposed by erosion on exposed Cretaceous formations. The Cretaceous and Tertiary units will be described in turn, beginning with the oldest. They are shown on plate 2 .

\section{CRITACBOUS SYBTEM}

\section{LANCE FORMATION}

Clay and sandstone of the Lance formation crop out in western Scotts Bluff County in two areas, one situated 1 to 3 miles north of Lyman and the other 4 to 6 miles south of that city. (See pl. 2.) It is also encountered in several wells in the area. Adequate discussion of this formation is made difficult because the surface exposures are rather poor, and wells entering it are not numerous. Its surface and subsurface relations have been studied by Schlaikjer ${ }^{28}$. According to Schlaikjer the Lance formation rests upon the Pierre shale. He states, however, that the Laramie-Fox Hills in the area may be represented as a zone within the Pierre. E. C. Reed ${ }^{24}$, Assistant State Geologist of Nebraska, is of

\footnotetext{
22 Darton, N. H., Preliminary report on the geology and water resources of Nebraska west of the one hundred and third meridian: U. S. Geol. Survey, 19th Ann. Rept., pt. IV o, pp 719-785, 1898; Preliminary report on the geology and water resources of Nebraska west of the one hundred and third meridian, U. B. Geol. Survey, Prof. Paper 17, pp. 1-69, 1903; Description of the Scotts Blufi Quadrangle, U. S. Geol. Survey, Geol. Atlas, Folio 88, 1803; Description of the Camp Clark Quadrangle, U. S. Geol. Survey, Geol. Atlas; Folio 87, 1803 .

28 Schlaikjer, Erich Maren, The Torrington momber of the Lance formation and a study of a new Triceratops: Contributions to the stratigraphy and paleontology of the Goshen Hole Area, Wyoming: Harvard Mus. Comp. Zoology Bull., vol. 76, No. 2, pp. 33-68, 1936.

24 Personal oommunication.
} 
the opinion that the Fox Hills sandstone, which in nearby Colorado and South Dakota occurs between the Lance and Pierre, is absent or lithologically unrecognizable in western Nebraska.

The area of outcrop that lies north of Lyman occupies sec. 15, 16, 21, 22,27 , and 28 , T. 23 N., R. $58 \mathrm{~W}$. There most of the exposed sediments of the Lance formation are sandstone. About a quarter of a mile west of the State line across from section 21 the following section was observed.

\section{Section of Lance formation north of Lyman, Nebr.}

Sandstone, platy, hard, thin-bedded, coarse to medium, weathered,
gray to buff; lower surface not a plane...
Sandstone, massive, medium-grained; contains numerous clay balls
along bedding planes; iron coneretions fairly common; crevices
filled with chalky white lime or by harder sandstone. Zone of
abundant clay balls at the top.
Covered slope...
Sandstone, hard, brown, showing both laminations and concentric
concretionary structure cutting across it; massive, but weathers
platy; where sound, it fractures across laminations with sub-
conchoidal fracture, but is not a quartzite....

Sandstone, soft, gray-brown, contains hollow concretions of limonite

Feet

2

3

12

4

10

2

This section lies at an altitude of about 4,030 to 4,080 feet above sea level. In these and in all other sandstones of the Lance formation observed, dark minerals, chiefly biotite, which are so abundant in the sands of the Tertiary formations, are lacking or uncommon. At a small road cut 3 miles directly north of Lyman on the road to Henry, more brown hard sandstone having a concentric structure is exposed at an altitude of about 4,060 feet. Still another outcrop of this sandstone is situated half a mile west of the point where Horse Creek crosses the State line into Scotts Bluff County, at an altitude of about 4,120 feet. A well on the property of J. F. Carland, 2 miles north of Lyman, and half a mile west, just beyond the State line, encountered yellow sandy clay between the depths of 4 and 87 feet below the surface. Four beds of hard sandstone or "limestone," each about $11 / 2$ feet thick, were met near the bottom. This yellow sandy clay is without doubt Lance. The well penetrated the plastic black clay of the Pierre at depths from 87 to 200 feet. The land surface at the well is at an altitude of about 4,090 feet above sea level.

The southern outcrop area covers part of sec. $21,22,27,28,33,34,35$, T. 22 N., R. 58 W., and sec. $2,3,4$, T. 21 N., R. 58 W. It consists of a buried hill of gently dipping Lance sediments, which have been cut into by a small tributary of Horse Creek. The creek has been ditched for drainage, exposing a part of the formation, which also appears on the hillside above. In sec. 34, T. 22 N., R. 58 W., the ditch cuts into ledges of brown, concretionary hard sandstone on the east slope of the valley. At a higher level on the west side is a surficial clay layer of the Chadron formation dipping off the pre-Chadron hill toward the east. Near the top of the slope, above the Lance outcrop in the ditch, some red clay is poorly exposed. Above the clay is a very poor exposure of basal conglomerate of the Chadron. In this same locality concretionary sandstone and bright mustard-yellow sandy clay appear on the walls of the ditch at the bottom of the valley, where the stream had cut through a Chadron 
bed. Bright yellow, plastic clay in the ditch about half a mile to the south contains abundant pebbles of jasper and small hollow limonite concretions. Perhaps the best exposures of the Lance in this area of outcrop are to be found in the locality where sec. $21,22,27$, and 28 join. In a small ditch at the north section-line road in sec. 28 , about 12 to 15 feet of it is exposed. Grayish sandstone tops the section, otherwise consisting chiefly of bright mustard-yellow sandy clay. It is highly plastic and minutely interbedded with paper-thin layers of fine sandstone, in which dark minerals are scarce or lacking. Some of the sandstones are concretionary; they thicken locally to as much as 18 inches. Where they are thick, cross bedding can be detected. Many thin, hollow limonite concretions are scattered through the section, and pink clay appears near the bottom.

A quarter of a mile slightly north of east of this point, in sec. 22 , the following section may be observed on the east wall of the valley:

Section of Lance formation south of Lyman, Nebr.

$\begin{array}{lr}\text { Sandstone, brownish gray, medium hard, with rounded grains; } & \text { Feet } \\ \text { dips } 5^{\circ} \text { or } 6^{\circ} \text { north, } 30^{\circ} \text { east..... } & 3 \\ \text { Sandstone, coarse gray, cemented with soft limy material, and } & \\ \text { brown clay. } & 1 \\ \text { Clay, soapy, rich brown, greenish and reddish near top; contains } & \\ \text { many limonite pebbles; dips } 6^{\circ} \text { north, } 30^{\circ} \text { east. } & 5 \\ \text { Sandstone, concretionary, brown, associated with brown and red } & \\ \text { clay on walls of ditch at bottom of slope. }\end{array}$

Farther south along the ditch, in section 27, reddish brown clay is interbedded with layers consisting of small broken bits of limonite concretions and with other layers made up almost wholly of black manganese concretions. Thin-bedded, concretionary, silty sandstone is associated with the clay. Up the eastern wall of the valley the mustard-yellow clay, with streaks of maroon clay, predominates, but limonite concretions, slabs of caliche like limy material, and large flint erratics are abundantly scattered through the section. Hard ledges of sandstone occur in all of this section but become persistent and thicker near the bottom. At a few points in this vicinity, near the bottom of the drainage ditch, masses of white, plastic, pure bentonite may be seen (or stepped in) and the same material has been encountered in wells. If properly described by the driller, the bentonite should be a good horizon marker, but probably is not very persistent.

In all, about 60 feet of Lance sediments are exposed in Scotts Bluff County, but that which crops out north of Lyman may not be the same part of the formation as that which crops out south of Lyman. Clay is by far the most abundant constituent of the sediments exposed, but sands of coarse to medium grain are numerous, both as knife-thin laminae in the clay beds, and as beds a foot or more in thickness. The hard concretionary brown sandstones are prominent because of their resistance to erosion and weathering, but they represent only a very small proportion of the whole formation exposed, and perhaps not half of the sandstones. The bright mustard-yellow color is characteristic of the formation and is easily detected on covered slopes and in canal diggings. The type of sedimentation suggests that of a continental deposit, and the fossil evidence obtained by Schlaikjer in the Goshen Hole area confirms this view. 
The Lance formation extends beneath the cover of Tertiary sediments and underlies much if not all of Scotts Bluff County. Logs of the following wells and test holes near the outcrop areas in the western part of the county show that the Lance is as much as 120 feet thick there.

Driller's $\log$ of flowing well F-15, about 7 miles south of Lyman in the $S E 1 / 4 S W 1 / 4$ sec. $2, T .21$ N., R. $58 \mathrm{~W}$.

\begin{tabular}{|c|c|c|}
\hline & $\begin{array}{c}\text { Thickness } \\
\text { (foet) }\end{array}$ & $\begin{array}{c}\text { Depth } \\
\text { (feet) }\end{array}$ \\
\hline $\begin{array}{l}\text { Soil } \\
\text { Hardpan (Brule formation) } \\
\text { Bog mud (aloughs in when being drilled) } \\
\text { Brownish sandstone. } \\
\text { Flow of water encountered at } 73 \text { feet. }\end{array}$ & $\begin{array}{l}10 \\
30 \\
25 \\
18\end{array}$ & $\begin{array}{l}10 \\
40 \\
65 \\
83\end{array}$ \\
\hline
\end{tabular}

Driller's log of a flowing well F-18, about 7 miles south of Lyman in the SE1/4 NE1/4 sec. $2, T .21$ N., R. $58 \mathrm{~W}$.

Drilled March 27, 1937, by Edward Douglas. The well, which is 5 inches in diameter, was pumped at a rate of 500 gallons an hour, during which time the water level declined to about 100 feet below the land surface.

Hardpan (Brule formation)

White bog mud

Sticky red clay

Black shale (still in it at total depth)

\begin{tabular}{|c|c}
$\begin{array}{c}\text { Thickness } \\
\text { (feet) }\end{array}$ & $\begin{array}{c}\text { Depth } \\
\text { (feet) }\end{array}$ \\
\hline 65 & 65 \\
25 & 90 \\
120 & 210 \\
+13 & 223 \\
\hline
\end{tabular}

Driller's log of flowing well F-17, near Wyoming-Nebraska State line about 7 miles south of Lyman in SW1/4 SE1/4 sec. 4, T. 21 N., R. 58 W.

Drilled in February 1937 by Edward Douglas.

\begin{tabular}{|c|c|c|}
\hline & $\underset{\text { (feet) }}{\text { Thickness }}$ & $\underset{\text { (feet) }}{\text { Depth }}$ \\
\hline $\begin{array}{l}\text { Hardpan (Brule formation) } \\
\text { Seep bog, white soapy bog material } \\
\text { Material unknown } \\
\text { Flow encountered below the white soapy bog. }\end{array}$ & $\begin{array}{l}46 \\
29 \\
101 / 2\end{array}$ & $\begin{array}{l}46 \\
75 \\
851 / 2\end{array}$ \\
\hline
\end{tabular}

Test hole 7, about 4.7 miles south of Lyman in NW1/4 SW1/4 sec. 26, T. 22 N., R. 58 W., at east side of road just north of bridge over irrigation ditch

\begin{tabular}{|c|c|c|}
\hline & $\underset{\text { (feet) }}{\text { Thickness }}$ & $\begin{array}{c}\text { Depth } \\
\text { (feet) }\end{array}$ \\
\hline $\begin{array}{l}\text { Light arenaceous clay. } \\
\text { Fine sandy Brule. } \\
\text { Gray sandy clay. } \\
\text { Same with greenish pieces... } \\
\text { Pinkish clay, sticky } \\
\text { Same, with pieces of water-worn brown and green clay } \\
\text { Yellow sand, much iron, layers of sandstone at } 87,891 / 4 \text {, and } 98 \text { feet } \\
\text { Sandy, sticky clay, some pink, soine blue, in layers; hard layers at } 123 \text { and } \\
163 \text { feet }\end{array}$ & $\begin{array}{l}\mathbf{1 1} \\
\mathbf{2 5} \\
\mathbf{1 1} \\
11 \\
10 \\
19 \\
19 \\
62\end{array}$ & $\begin{array}{r}11 \\
36 \\
47 \\
58 \\
68 \\
87 \\
106 \\
168\end{array}$ \\
\hline
\end{tabular}

In well F-15 the brownish sandstone from 76 to 83 feet is undoubtedly the Lance. In well F-13 the white bog mud from 65 to 90 feet may be the bentonite near the top of the Lance, or it may be a whitish clay in the Chadron. In any case, the red clay from 90 to 210 feet is quite certainly the Lance, and the black clay at the bottom of the well is 
probably the Pierre. In well F-17 the seep-bog, white soapy material would be an apt description of the bentonite in the Lance, and is taken as such. The Lance, then would include all material below the 46 -foot level. In test hole 7 the pink clay and yellow sand below the depth of 58 feet belong to the Lance, and that material between the depths of 36 and 58 feet is the Chadron. Schlaikjer gives drillers' logs of some test wells in the Goshen Hole area, which are located 15 to 20 miles about due west of the wells and test hole cited above. They show that about 100 feet of Lance was encountered there but at altitudes of somewhat more than 200 feet higher than in western Scotts Bluff County. The Simpson test well, whose log follows, is about 7 miles almost due east of well F-13.

Log of Simpson well, drilled on the Currie ranch about 0.5 mile east of Signal Butte in the SW1/4 NE1/4 sec. 14, T. 21 N., R. $57 W$.

Courteny of Charles Goodell, Scottsbluff, Nebr., promoter; A. A. McPherson, Scottebluff, Nebr., driller. Altitude of portal, 4,431 feet.

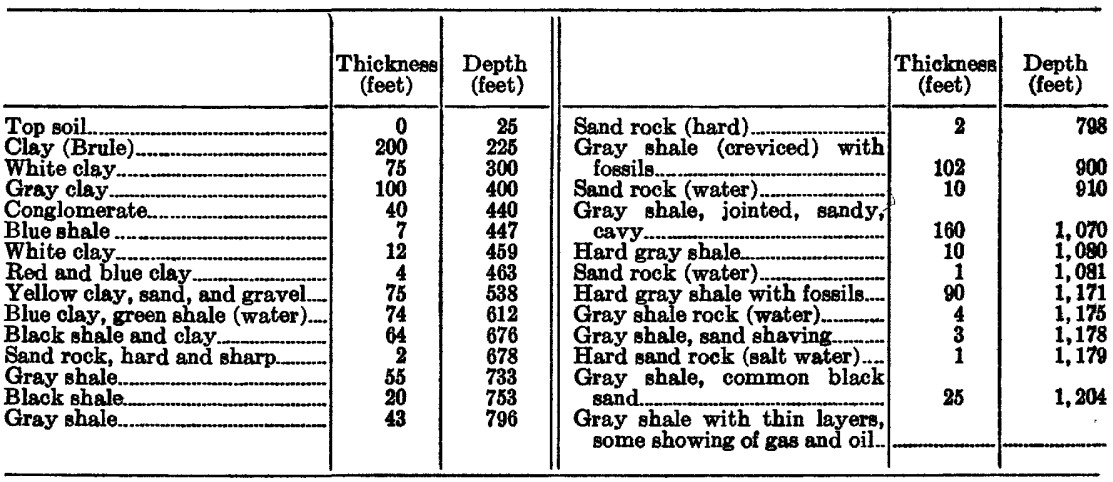

By way of digression, it will be noted that the Chadron formation has thickened greatly, and apparently comprises the white, gray, and blue clay and conglomerate lying at depths of 225 and 459 feet. Likewise, the Lance has grown thicker, comprising the red, blue, and green sand, gravel, clay, and shale lying between the depths of 459 and 612 feet. Below it is the Pierre.

Wells at Scottsbluff and Gering, on a north-south line 12 miles farther east than the Simpson well, pass through the Chadron and Lance and penetrate the Pierre shale.

Log of well F-R, in southwestern corner of city of Gering

Altitude about 3,920 feet above sea level. Drilled by Phil Fulton.

\begin{tabular}{|c|c|c|c|c|c|}
\hline & $\begin{array}{c}\text { Thicknees } \\
\text { (feet) }\end{array}$ & $\begin{array}{l}\text { Depth } \\
\text { (feet) }\end{array}$ & & $\begin{array}{c}\text { Thickness } \\
\text { (feet) }\end{array}$ & $\begin{array}{l}\text { Depth } \\
\text { (feet) }\end{array}$ \\
\hline $\begin{array}{l}\text { Silt, clay, wash from hills...... } \\
\text { Brule. } \\
\text { Blue shale, solid fine grained. } \\
\text { Greensand, fine, unconsolidated, } \\
\text { flowed up casing to within } \\
120 \text { feet of the surface.. } \\
\text { White material, hard to drill; } \\
\text { shook like jelly in slush pit } \\
\text { (bentonite) } \\
\text { First water, flow, encountered } \\
\text { immediately below white } \\
\text { material. }\end{array}$ & $\begin{array}{r}23 \\
57 \\
205\end{array}$ & $\begin{array}{r}23 \\
80 \\
285 \\
\\
300\end{array}$ & $\begin{array}{l}\text { Green fine sand, almost quick- } \\
\text { sand. } \\
\text { Red rock, rubbery, hard to drill } \\
\text { Second flow below red rock, } \\
\text { small quantity . } \\
\text { Green sand, coarser than first, } \\
\text { and did not flow into hole. } \\
\text { Yellow olay, greasy; came out } \\
\text { in chunks. } \\
\text { Black shale, greasy, rubbery, } \\
\text { contains pyrite, no water... }\end{array}$ & $\begin{array}{r}5 \\
10 \\
5 \\
20 \\
20 \\
185\end{array}$ & $\begin{array}{l}320 \\
330 \\
335 \\
355 \\
375 \\
560\end{array}$ \\
\hline
\end{tabular}


The blue shale between the depths of 80 and 285 feet is Chadron. The green sand beginning at 285 is considered the uppermost member of the Lance, chiefly because similar material was logged farther down in the well in the Lance. If this sand is the top of the Lance, then the 90 feet of material down to a depth of 375 feet must represent the whole formation, for the Pierre comes in at that depth. Bentonite similar to that found exposed in the Lance was encountered between 300 and 315 feet. It is not probable that the bentonite is Chadron, and that the top of the Lance was encountered at a depth of 320 feet.

\section{Log of well F-S of the City of Scottsbluff}

Drilled by A. A. McPherson; depth 303 feet; diameter of casing $4 \frac{1}{2}$ inches; altitude 3,884 feet.

\begin{tabular}{|c|c|c|c|c|c|}
\hline & $\begin{array}{c}\text { Thickners } \\
\text { (feet) }\end{array}$ & $\begin{array}{c}\text { Depth } \\
\text { (feet) }\end{array}$ & & $\begin{array}{c}\text { Thickness } \\
\text { (feet) }\end{array}$ & $\begin{array}{l}\text { Depth } \\
\text { (feet) }\end{array}$ \\
\hline $\begin{array}{l}\text { Soil } \\
\text { Sand and gravel, very uniform } \\
\text { and high percentage of coarse } \\
\text { gravel } \\
\text { Clay, (Brule), compact.-.-- } \\
\text { Hard shale. } \\
\text { Blue clay of varying texture and } \\
\text { hardness interlayer with thin } \\
\text { sheets of crystal rock, also } \\
\text { broken pieces of rock re- } \\
\text { sembling agate...- } \\
\text { Opaque, shale, blue. }\end{array}$ & $\begin{array}{r}41 \\
54 \\
3\end{array}$ & $\begin{array}{r}5 \\
46 \\
400 \\
103\end{array}$ & 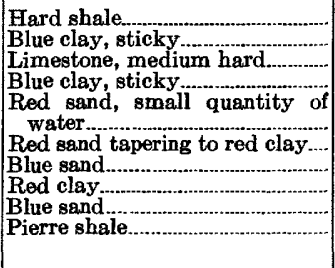 & $\begin{array}{r}10 \\
10 \\
1 \\
73 \\
\\
6 \\
23 \\
1 \\
1 \\
6 \\
20 \\
3\end{array}$ & $\begin{array}{l}160 \\
170 \\
171 \\
244 \\
\\
250 \\
273 \\
274 \\
280 \\
300 \\
303\end{array}$ \\
\hline
\end{tabular}

At 280 feet water entered hole flowing 45 gallons a minute and having a pressure of 25 pounds per square inch at surface. A larger well was later drilled, but because of an error in casing this well did not flow as much as the test well and showed less than 15 gallons a minute when pumped with a turbine pump. A $151 / 2$-inch casing was set on Pierre shale at 303 feet and the well drilled to a depth of 840 feet. No more water was encountered.

The material between the depths of 100 or 103 and 244 feet is considered to be Chadron, but it is possible that some of the lower part is Lance. The red sand at depths of 244 to 250 feet is certainly Lance, and the Pierre shale begins at 300 feet, for, as the log notes, 540 feet more of hole was later drilled. If the interpretation is correct, then the Lance is only 56 feet thick. It turns out, however, that this thinning toward the north is consistent in comparison with a deep test in Banner County. This test, whose $\log$ is given in the publication on deep wells of Nebraska, Nebraska Geological Survey Bulletin 4, second series, pages 251 to 253, was put down by the Prairie Oil and Gas Company in the NE $1 / 4$ NE $1 / 4$ sec. 33 , T. 19 N., R. $55 \mathrm{~W}$. The altitude of the land surface at that point is about 4,500 feet above sea level. It is about 20 miles due south of the Scottsbluff test well and 16 or 17 miles south of the Gering well, both of whose logs are given above. In the Prairie Oil and Gas well 305 feet of Lance lie at altitudes of from 3,665 to 3,970 feet above sea level. At Gering the 90 feet of Lance lie between the altitudes of 3,445 and 3,635 feet, and at Scottsbluff 56 feet of Lance lie between 3,590 and 3,646 feet. These relations show that the top of the Pierre is rising toward the north, but due to thinning, the top of the Lance is also sloping toward the north.

Viewed in large scale, the subsurface evidence available indicates that the Lance dips toward the east at an average rate of about 16 feet to 
the mile. This dip is by no means uniform, however, for between the Simpson test hole and the Gering City well it is about 13 feet to the mile, but between well 385, south of Lyman, and the Simpson test hole it seems to be 25 to 30 feet to the mile. A slight thinning accompanies the eastward dip. In well 385 the Lance is 120 feet thick, in the Simpson well it is 179 feet thick, and at Gering it is only 90 feet thick. The thinning does not progress uniformly, but probably indicates a trend. In the area south of Mitchell, but north and east of the Simpson well, some test holes were put down with the State-owned rig through a greater section of Chadron than any encountered in the wells thus far referred to. If the Lance lies below the bottom of these holes it must have been downwarped sharply.* A dip in the outcrop in section 22, T. 21 N., R. 58.W. of $6^{\circ}$ north $30^{\circ}$ east may indicate such a sharp, local trough. However, more probably the Lance was deeply eroded in this locality before the Chadron was deposited., and the Teritary beds may rest directly on the Pierre. The northward thinning of the Lance tends to strengthen this possibility.

There is reason to believe that the Lance extends toward the east and southeast beyond the limits of the county. Predicting the position of the Lance formation in detail by means of a few scattered well logs is precarious, however, because its upper surface was eroded into high relief before the deposition of the Chadron formation. It also seems to have been deformed. Its position might be predicted fairly successfully in the part of Scotts. Bluff County that lies south of the North Platte, but north of the river its thickness and depth, even its presence, are uncertain.

Beds of sand that are capable of yielding small or moderate supplies of ground water are numerous in the Lance formation. They do not seem to be very thick, or very coarse in grain. Their importance, however, may be enhanced by their position beneath the Brule and Chadron formations, which in many places are barren of water. Where the' Lance is not deeply buried and the Brule and Chadron are thin, as in the western part of the county it is the source of domestic and stock supplies for farms. Most of these wells flow at the' ground surface at a rate of from a trickle to about 1.2 gallons a minute. One of the wells was given a pumping test that showed its yield to be about 500 gallons an hour with a 100-foot draw-down. Fine-grained sediments in the Chadron formation constitute the confining bed in the areas of artesian pressure. Farther east, also, the water in the Lance is under artestian head, and at the cities of Scottsbluff and Gering wells drilled into it flowed at the ground surface. Here the wells were of larger diameter than those in the western part of the county; the well at Scottsbluff flowed at a rate of 25 gallons a minute, according to the drillers' reports. Nevertheless, these Lance wells were abandoned, and new wells were drilled into alluvium for the city supplies.

\section{TERTIARY SYSTEM}

WHTTE RIVER GROUP

Primarily sediments of silt and clay size, the White River group underlies the bottom and lower slopes of the North Platte Valley, and hence, most of the area of the County. (See pl. 2.) It consists of two formations, the lower being the Chadron and the upper, the Brule. 
Resting upon an erosion surface developed on the Lance formation chiefly during the early part of the Tertiary period, the White River group belongs entirely to the Oligocene; the sediments overlying it are of Miocene age. The division of the White River into two formations was made chiefly on the basis of faunal differences, the Chadron was originally called the Titanothere beds but there are also lithologic differences.

$:$

CEADRON PORMATION

The Chadron formation consists mainly of green and brown plastic clay, grading upward into, or overlain by, light green silty clay or clayey silt whose composition approaches more and more that of the Brule near the top. Buried channels of sand and even gravel wind through. the formation, but in Scotts Bluff County the coarse material is not abundant. The Chadron formation is exposed at the land surface only in the western part of the county, where it flanks the outcrop areas of the Lance formation, and along the North Platte River near Henry and Morrill. Beneath a cover of Brule, however, it probably underlies the entire county.

The basal beds of the Chadron formation, near the contact with the Lance, consist of dull-green and earthy-brown clay. It is so plastic, well sorted, and unconsolidated that it resists weathering and erosion very little, and consequently is rather poorly exposed. Flat slopes are developed on it, for it will not stand in a bank. In a number of places it can be seen as a thin mantle sloping on down the ancient sides of the Lance hills, and passing beneath the Brule formation in the lowlands. Thus, in Wyoming, just across the State line from sec. 33, T. $23 \mathrm{~N}$;, R. $58 \mathrm{~W}$. and in sec. $34, T, 22$ N., R. 58. W., a thin deposit of Chadron covers the east side of hills composed of nearly flat-lying Lance sediments. Farther down the slopes of the hills the Chadron thickens wedgelike; back beneath the covering of Brule it thickens greatly, in the manner of a valley fill. It is possible that at the tops of the hills the Chadron is paper thin, or even absent.

In the southwest corner of sec. 35 , T. 22 .N., R. $58 \mathrm{~W}$. a poor exposure of brown Chadron clay lies at a slightly higher altitude than some mustard-yellow sandy clay of the Lance that is seen on the walls of a nearby ditch. The brown clay is overlain by 4 feet of coarse gray sand with a high content of dark minerals and fragments of lime, limonite concretions, and pebbles of jasper, and this in turn is overlain by 2 feet more of green and brown clay. This material lies at the foot of a bank composed of typical Brule. In the southeast corner of sec. 27, T. $22 \mathrm{~N}$.; R. $58 \mathrm{~W}$. the Lance is overlain by a few feet of the same clay, dark olive-green where fresh, but brown earthy, flaky, or platy clay where weathered. In the Chadron are numerous pieces of gray calichelike lime, limonite fragments, chert, and manganese pebbles. The limy fragments are most abundant near the middle of the exposed section. The clay seems to become more silty upward, but above a rather definite break there are 4 or 5 feet of light-green consolidated silt, resembling Brule in composition, and like it forms a small bank or escarpment. The Brule overlies this material. In the northern parts of sec. 3 and 4, T. 21. N., R. 58 W., is another flat surface, underlain by clay of the Chadron formation, in which limy and limonite fragments abound, but on which, in addition, pieces of titanothere teeth may be seen scattered about. Material of the same type 
is exposed on the terrace face just north of the village of Henry, where it is overlain by the gravels of the third terrace. In numerous other spots in the general outcrop area the clay can be recognized on its flat exposures by the crinkly, lumpy, or platy form it assumes when weathered and dry.

Mechanical analysis of a clay sample from the Chadron formation, made in the hydrological laboratory of the Geological Survey in Washington, D. C., shows that it is a rather well-sorted deposit composed of clay-sized particles.

Grain size in millimeters
More than 0.125 (coarser than very fine sand)

A sample of the same material was examined microscopically by Charles Milton in the chemical laboratory of the Federal Geological Survey, and it was found to consist almost wholly of decomposed volcanic ash. To quote Milton's report: "Appears to be a clay of volcanic origin, consisting mostly of compacted, devitrified volcanic ash, originally pumicite. Some particles of quartz, sodic feldspar, and altered mica are present. Probably a reworked deposit." Judging from the composition and field relations of this clay, particularly the manner in which it cloaks the topography on the upper surface of the Lance and slopes away, thickening, the deposit is a reworked ash, laid down by streams on the floodplains, and probably scattered and redeposited by the winds. . In fact, the possibility must be considered that the wind was an important agent in the deposition of the fine-grained sediments of the Chadron formation.

Sand and sandstone, with local lenses of gravel, are reported in the Chadron in other localities. A channel of such coarse material was traced for some distance in the Goshen Hole district by Schlaikjer. ${ }^{25}$ Aside from a basal sandstone or conglomerate, which is reported in many places, the channel deposits in the Chadron are most abundant near the top of the formation. This makes it rather difficult to distinguish the Chadron and Brule by means of the lithology, because the Brule contains - similar channel deposits near its base. The following section is exposed about midway between Mitchell and Morrill, on the south side of the river:

25 Schlaikjer, E. M., New vertebrates and the stratigraphy of Oligocone and early Miocene. Harvard Mus. Comp. Zoology, Bull. vol 76, pt. 4, pp. 97-189, 1933 . 
Section of Chadron formation in sec. 36, T. 2S. N., R. 57 W.

Siltstone of the Brule formation, typical, tan to flesh-colored; at top of section.

Zone of alternating layers, 1 to $2 \frac{1}{2}$ feet thick, of tan to fleshcolored Brule, or Brulelike silt, and greenish-gray beds of fine, sof $t$ sandstone, the sandstone beds becoming thinner and less numerous upward

Sandstone, massive, fine-grained, containing clay and silt, and stained brown on outcrop

Sandstone, coarse, cross-bedded, light-gray, micacoous, fairly soft; deposited on uneven surface; average thickness.

Silt, gray-green, sandy, in beds about 3 inches thick alternating with 8-inch beds of soft sandstone.

Shale, hard, olive-green, sandy

Covered slope.

Sandstone, medium to coarse, light-gray, with much mica; laminated and fissile; some cross bedding visible; local pockets or channels of eonglomerate.

Silt, gray, micaceous, sandy; lowest exposure of section.

The hard green sandy shale in the section suggests Chadron material met with in some of the test holes. To place the contact between the Chadron and Brule formations precisely would probably be impossible in this locality without the aid of fossils, but it probably lies in the sandstone near the top of the section. The green or gray color in the silts is indicative, but some thin zones in the lower part of the Brule formation also are probably gray and green.

Mention has already been made of light-green silts in the Chadron formation. Three general types may be noted: a greenish-white, soft, limy phase, characterized chiefly by a very low specific gravity; a hard, massive, olive-green silt containing sand and plastic clay in small amount; and a blocky or massive silt that resembles the Brule in other respects than color. The third type mentioned is best exposed in outcrops, but the second type seems to be most abundant beneath the surface of the ground. The first type of material was found in only one locality northwest of Lyman, just across the State line in Wyoming.

The subsurface relations of the Chadron formation are rather complicated. Uncertainty exists because of the relatively small number of wells known to enter the formation in the county and the possibility of incorrect interpretation of the logs. The log of test hole 7, shows gray sandy clay from 36 to 47 feet, and a similar material containing "greenish pieces" from 47 to 58 feet. The 22 feet of sandy clay so delineated are considered to be Chadron. The materials between 225 feet and 459 feet are believed to represent the Chadron.

Here the Chadron is 234 feet thick. According to the $\log$ of the Gering City well solid, fine-grained blue shale, was encountered from 80 to 285 feet. This material is considered to be Chadron. At Scottsbluff, the log of the city well F-3 shows that shale, clay, limestone, and some pieces of crystal rock were encountered between depths of $\mathbf{1 0 0}$ and 244 feet.

If all of this material belongs in the Chadron, as the description suggests, then the formation is about 60 feet thinner than at Gering, a short distance away.

The following test holes, put down in connection with the present investigation entered what is believed to be the Chadron formation. 
Test hole 2, north of road, about 0.25 mile east of section corner in SW1/SW1/4sec. $s$, R. 56 W., T. 28. N., on Hugo Peiper farm, south of Mitchell

\begin{tabular}{|c|c|c|c|c|c|}
\hline & $\begin{array}{c}\text { Thiokness } \\
\text { (feet) }\end{array}$ & $\begin{array}{c}\text { Depth } \\
\text { (feet) }\end{array}$ & & $\begin{array}{c}\text { Thioknees } \\
\text { (feet) }\end{array}$ & $\begin{array}{l}\text { Depth } \\
\text { (feet) }\end{array}$ \\
\hline 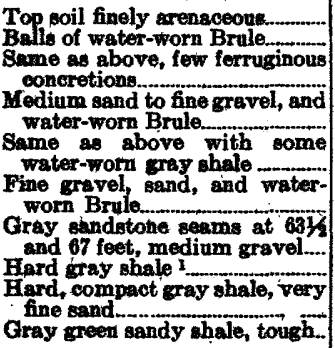 & $\begin{array}{c}10 \\
10 \\
12 \\
11 \\
12 \\
816 \\
116 / 6 \\
10 \\
6 \\
20\end{array}$ & $\begin{array}{l}10 \\
20 \\
32 \\
43 \\
.55 \\
6836 \\
75 \\
94 \\
100 \\
120\end{array}$ & 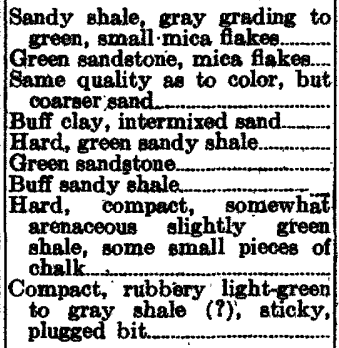 & $\begin{array}{r}15 \\
10 \\
1 \\
7 \\
11 \\
7 \\
5 \\
10\end{array}$ & $\begin{array}{l}135 \\
145 \\
152 \\
168 \\
170 \\
175 \\
185\end{array}$ \\
\hline
\end{tabular}

1 The gravel seems to reat directly upon the Chadron, which prevails from 75 to 206 feet, for a total of 181 feot. The plastic elay in the last few foet of hole suggests that the bottom of the formation is not far below.

Test hale S, west side of road, about 7.5 miles southwest of Mitchell, in NE cor. SE1/4 sec. $18, R .56$ W., T. 22 N.

\begin{tabular}{|c|c|c|c|c|c|}
\hline$\cdot$. & $\begin{array}{c}\text { Thickness } \\
\text { (feet) }\end{array}$ & $\underset{\text { (feet) }}{\text { Depth }}$ & $\checkmark$ & $\underset{\text { (foet) }}{\text { Thickness }}$ & $\begin{array}{l}\text { Depth } \\
\text { (feet) }\end{array}$ \\
\hline $\begin{array}{l}\text { Soil. } \\
\text { Clay, pinkioh-brown } \\
\text { Clay, pinkish-brown, and a little } \\
\text { bluigh-green, a amall gastro- } \\
\text { pod found, drilling harder bt } \\
\text { 37 feet. } \\
\text { Clay, ohisefy greenish and some- } \\
\text { what arenaceous, getting } \\
\text { brown at 58 feet... } \\
\text { Clay, mostly brown tough. } \\
\text { Clay, greenish, tough }\end{array}$ & $\begin{array}{l}24 \\
\cdot \\
15 \\
5 \\
2\end{array}$ & $\begin{array}{l}53 \\
58 \\
60\end{array}$ & $\begin{array}{l}\text { Clay, green, blue, brown, tough. } \\
\text { Clay, gray, tough } \\
\text { Clay, blue, soft at } 148 \text { feet... } \\
\text { Clay, gray. } \\
\text { Clay, gray, blue, and pinkish- } \\
\text { brown pieces } \\
\text { Same but with soit white ma- } \\
\text { terial, and soft brown ma- } \\
\text { terial. From } 300 \text { feet to } 318 \\
\text { feet of hard drilling (second- } \\
\text { ary calcite vugs). }\end{array}$ & $\begin{array}{r}5 \\
1 \\
92 \\
12 \\
130\end{array}$ & $\begin{array}{r}65 \\
66 \\
158 \\
170 \\
300\end{array}$ \\
\hline
\end{tabular}

The material from 60 to 65 feet suggests the alternation of buff and green silt seen in some places in the lower zones of the Brule. If so, the Chadron seems to begin at a depth of 65 feet and to carry through to the bottom of the hole at 330 feet, a thickness of 265 feet, with an unknown amount below the bottom of the hole.

Test hole 4, north side of road SW1/4.SE1/4 sec. $1, T$. 22 $N ., R .58 W ., 1$ mile south and 3 miles east of Lyman

\begin{tabular}{|c|c|c|}
\hline 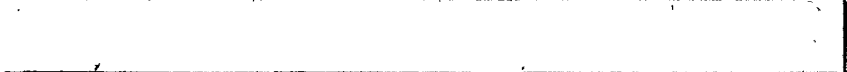 & $\begin{array}{c}\text { Thickness } \\
\text { (feet) }\end{array}$ & $\begin{array}{l}\text { Depth } \\
\text { (feot) }\end{array}$ \\
\hline 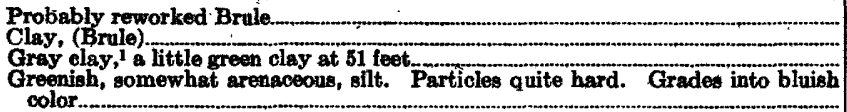 & $\begin{array}{r}23 \\
23 \\
\mathbf{1 5} \\
21\end{array}$ & $\begin{array}{l}29 \\
46 \\
61 \\
82\end{array}$ \\
\hline
\end{tabular}

1 The gray clay beginning at a depth of 46 feet and carrying through to 82 feet is probably the Chadron.

Test hole 5, about 0.3 mile north of section corner, SE1/4 sec. \$1, T. 2S N., R. 57 W., $41 / 2$ miles east and 0.3 mile north of Lyman

Cland, Tight-oolored, hard, arenaceous, oolor slowly changing to green at 12 feet....

Clay, greenish and gray color.1 Hard drilling

\begin{tabular}{|c|c|}
\hline $\begin{array}{c}\text { Thicknese } \\
\text { (feet) }\end{array}$ & $\begin{array}{l}\text { Depth } \\
\text { (feet) }\end{array}$ \\
\hline $\begin{array}{r}11 \\
1 \\
19\end{array}$ & $\begin{array}{l}11 \\
12 \\
31\end{array}$ \\
\hline
\end{tabular}

1 The lower 19 feet of material in this hole prbbably represent a part of the Chadron formation.' 
Test hole 6, south side of road 1.6 mile west of south Morrill station, in NE1/4 NW1/4 sec. $32, T .23 N ., R$. $57 W ., 0.6$ mile west of section line

\begin{tabular}{|c|c|c|}
\hline . & $\begin{array}{c}\text { Thickness } \\
\text { (foet) }\end{array}$ & $\underset{\text { Depth }}{\text { Deet) }}$ \\
\hline $\begin{array}{l}\text { Sand and soil (road fill) } \\
\text { Sand, fine } \\
\text { Clay, bluish, muddy } \\
\text { Sand, coarse } \\
\text { Sand, coarse, with greenish elay } \\
\text { Clay, soft and hard, greenish and gray, arenaceous } \\
\text { Clay, grading into black }\end{array}$ & $\begin{array}{l}2 \\
8 \\
21 / 2 \\
151 / 4 \\
14 \\
122 \\
26\end{array}$ & $\begin{array}{c}2 \\
10 \\
121 / 2 \\
28 \\
42 \\
164 \\
190\end{array}$ \\
\hline
\end{tabular}

Below the alluvium, at 42 feet, and from thence to a depth of 164 feet, the description of the material fits the Chadron very well. From 164 to 190 feet, the significance of the gradation toward black color is puzzling. It may be that the well entered the Pierre, as the drillers thought, or that the Chadron derives its dark color from reworked Pierre shale obtained locally, or perhaps such color can normally be expected in the Chadron at certain localities or under certain conditions. Of the three possibilities, the second seems the most probable: that the Lance has been removed, and the Chadron, overlying the Pierre shale, contains material derived locally from it. In this case the Chadron is 148 feet thick, unless a part of the lower 26 feet is actually Pierre.

Test hole 9, south of Morrill. SE1/4 SE1/4 sec. 21, T. 2S N., R. F7 W., just south o, first irrigation ditch north of river, on west side of road

\begin{tabular}{|c|c|c|}
\hline & $\begin{array}{c}\text { Thickness } \\
\text { (feet) }\end{array}$ & $\begin{array}{l}\text { Depth } \\
\text { (feet) }\end{array}$ \\
\hline $\begin{array}{l}\text { Sand } \\
\text { Sand, coarse, and fine gravel. Some coarse gravel below } 95 \text { feetr } \\
\text { Clay, blue, some greenish. }\end{array}$ & $\begin{array}{r}6 \\
141 \\
6\end{array}$ & $\begin{array}{r}6 \\
147 \\
153\end{array}$ \\
\hline
\end{tabular}

I Gix feet of Chadron was penetrated after the well had passed through the alluvium.

Test hole 13, 0.35 mile east of Broadway Street and 0.45 mile sauth of Overland Street, Scottsbluff, in SE1/4NE1/4 sec. 26, T. $22 N$., R. $55 \mathrm{~W}$.

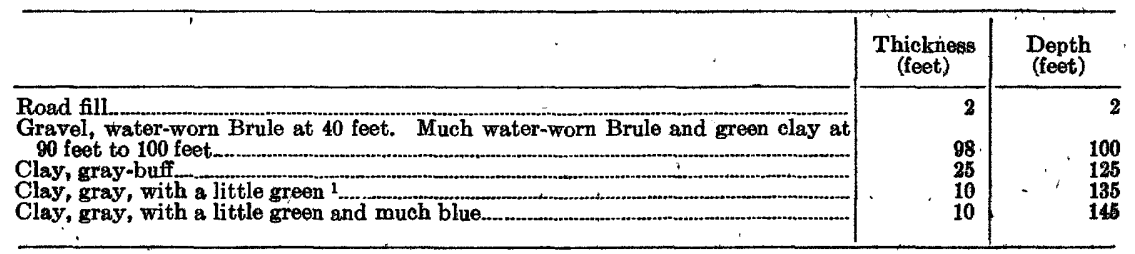

1 The bottom 20 feet of material seems to belong to the Chadron formation.

Test hole 14, 0.8 mile north of corner, on west side of road, $S E 1 / 4 S E 1 / 4$ sec. $13, T .22 N ., R .5 E W$.

\begin{tabular}{|c|c|c|}
\hline 1 & $\begin{array}{c}\text { Thiokness } \\
\text { (feet) }\end{array}$ & $\begin{array}{l}\text { Depth } \\
\text { (feet) }\end{array}$ \\
\hline $\begin{array}{l}\text { Reworked sand and gravel. } \\
\text { Gravel } \\
\text { Whitish sandy clay } \\
\text { Gravel. } \\
\text { Clay, gray, with some green, first } 5 \text { feet lighter in color } 1\end{array}$ & $\begin{array}{r}17 \\
4 \\
4 \\
15 \\
20\end{array}$ & $\begin{array}{l}17 \\
21 \\
25 \\
40 \\
60\end{array}$ \\
\hline
\end{tabular}

1 The last 20 feet of material is probably Chadron. 
Test hole 15, NW1/4SW1/4SW1/4 sec. 38, T. $23 N$., R. $54, W, 0.15$ mile north of section corner, east side of road, and'just south of irrigation ditch

\begin{tabular}{|c|c|c|}
\hline , & $\begin{array}{l}\text { Thickness } \\
\text { (feet) }\end{array}$ & $\begin{array}{l}\text { Depth } \\
\text { (feet) }\end{array}$ \\
\hline Band & $\begin{array}{r}18 \\
186\end{array}$ & $\begin{array}{r}18 \\
204\end{array}$ \\
\hline
\end{tabular}

1 Presumably, where the gray color becomes prominent the Chadron was encountered. Thickness of Chadron penetrated, therefore, was 44 feet.

Test hole 18, about 100 yards south of irrigation ditch, in $S E 1 / 4 N E 1 / 4$ sec. $35, T$. 88 N., R. $55 W$ :

\begin{tabular}{|c|c|c|}
\hline & $\begin{array}{c}\text { Thickness } \\
\text { (feet) }\end{array}$ & $\begin{array}{l}\text { Depth } \\
\text { (feet) }\end{array}$ \\
\hline $\begin{array}{l}\text { Topsoil, sand } \\
\text { Gravel }\end{array}$ & $\begin{array}{r}6 \\
42\end{array}$ & $\begin{array}{r}6 \\
48\end{array}$ \\
\hline
\end{tabular}

1 The green color at 78 feet probably marks the top of the Chadron.

Test hole $28,0.1$ mile north of section corner, on east side of road, in $S W 1 / 4 S W 1 / 4$ sec. $29, T .21$ N., R. $55 W$.

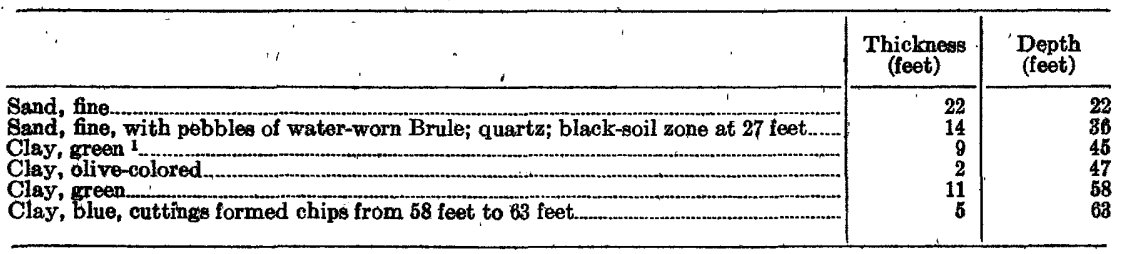

The lower 27 feet appears to be Chadron.

Test hole 27, east side of road, about 75 yards south of section line, in $N W 1 / 4 N E 1 / 4$ sec. 7,.T. $21 N$., R. $58 W$.

\begin{tabular}{|c|c|c|}
\hline . & $\begin{array}{c}\text { Thickness } \\
\text { (feet) }\end{array}$ & $\begin{array}{c}\text { Depth } \\
\text { (feet) }\end{array}$ \\
\hline $\begin{array}{l}\text { Topsoil. } \\
\text { Gravel; some water-worn Brule at } 36 \text { feet, large amount from } 85 \text { to } 92 \text { feet } \\
\text { Sand and fine gravel } \\
\text { Gravel; at } 135 \text { feet a little blue silty mud } \\
\text { Gratel, boulders, hard to drill. } \\
\text { Clay, pinkish-tan. } \\
\text { Clay, gray }{ }^{1}\end{array}$ & $\begin{array}{l}31 / 2 \\
881 / 2 \\
7 \\
79 \\
17 \\
17 \\
12\end{array}$ & $\begin{array}{r}31 / 2 \\
92 \\
99 \\
178 \\
195 \\
\cdot \quad 212 \\
224\end{array}$ \\
\hline
\end{tabular}

1 Identification of the last 12 feet of gray clay as Chadron would be strengthened if a greater thickness had been penetrated. However, its identification is probable, if not positive.

Test hole \$2, north side of road, east of headgates, about 0.3 mile east of river bridge, in $S W 1 / 4 S E 1 / 4$ sec. $25, T .21 N ., R .63 \mathrm{~W}$.

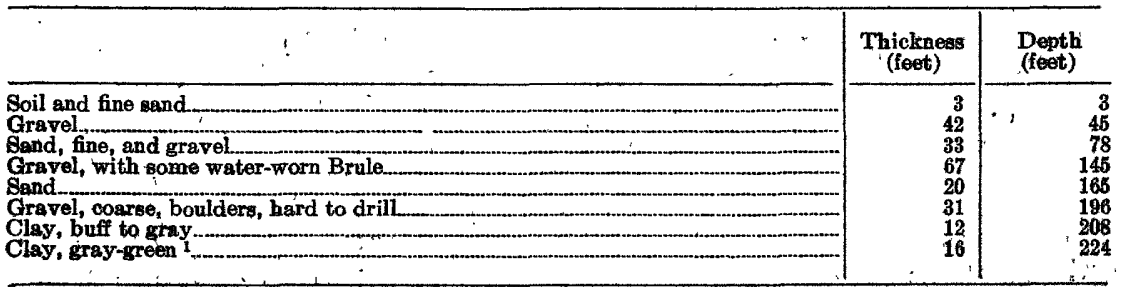

1 Here asain the bottom 16 feet is identified as Chadron, but its identification would be strengthened if more had been penetrated. 
Test hole 35,25 feet east of observation well 195 , in $N W 1 / 4 S E 1 / 4$ sec. $11, T .82 N$., R. $56 \mathrm{~W}$.

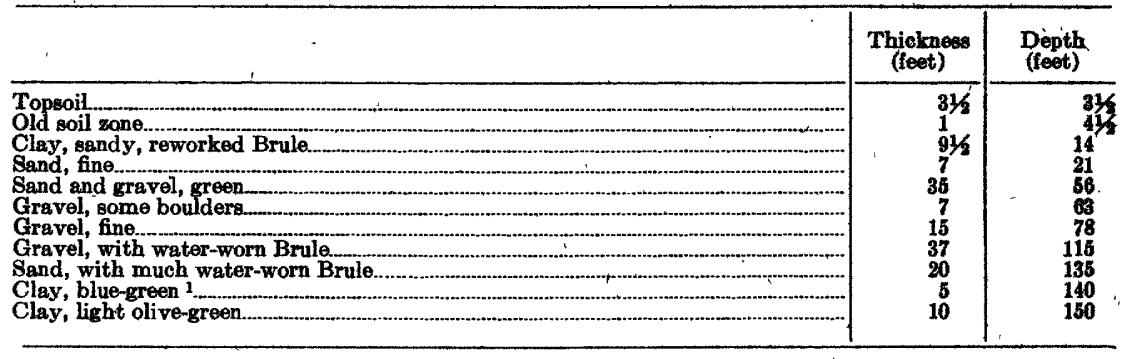

1 The last 15 feet of material encountered in this test holo probably belongs in the Chadron formation.

The thickness of the Chadron formation and the position of its top surface undergo certain changes that are incompletely revealed by the logs of wells and test holes. The formation is thin in the outcrop area in the western part of the county. South of Mitchell, test drillings show that it is over 265 feet thick, but farther south at the Simpson test well it is only 84 feet thick. At Gering it is 205 feet thick, and across the river at Scottsbluff it is 144 feet thick. These regional relations strongly suggest that a deep valley was cut into the surface of the Lance before the Chadron was deposited, somewhere north and east of the areas prospected by drilling. It will be recalled that the Lance shows a decrease in thickness toward the north. The great thickening of the Chadron formation in the vicinity of Mitchell may mean that a tributary stream had eroded a deep valley back into the pre-Oligocene land surface from the north or northeast, which was filled in Chadron time.

The Chadron formation is predominantly fine grained in Scotts Bluff County, and there are no large openings in it, hence it is a-poor source of ground-water supply. Although channels filled with coarse sediment exist in some places in the formation, no wells are known to have encountered one. Nor have any of the wells in the county obtained any measurable quantity of water from the formation, so far as the available records show.

\section{BROLE FORMATION}

The Brule formation is magnificently exposed on the bluffs and slopes in Scotts Bluff County. (See pl. 2.) It is chiefly a ruddy-buff, or fleshcolored silt, massive and featureless in fresh exposures, but weathering into brick-shaped blocks or slabs. Although bedding is rarely seen, zones of more compact or more limý material exhibit greater resistance to weathering and erosion, producing an effect of layering which shows up best where the Brule has been eroded into badlands. At Seotts Bluff Monument its thickness, revealed by the $\log$ of the Gering City well and the section exposed, is about 560 feet.

Two samples of the Brule formation were examined microscopically in the chemical laboratory, and analyzed according to size of grain in the hydrologic laboratory of the Geological Survey in Washington, D. C. The first sample was taken from the face of Scotts Bluff Monument halfway between tunnels Nos. 1 and 2, and 140 feet below the Gering contact, where fresh material was being excavated for the construction of a 
road up the bluff. The material there is typical of the greater part of the formation, the massive flesh-colored silt. Mechanical analysis shows the grain size as follows:

Orain size (diameter) in millimeters

Greater than 0.125 (coarser than very fine sand)

0.125 to 0.062 (very fine sand)

0.062 to 0.005 (silt)

Less than 0.005 (clay)

Eighty-eight percent of the material was composed of very fine, sand and silt, and almost 70 percent was silt. An ash bed in the Brule at the lower portal of turinel No. 2 was also analyzed and showed a similar mechanical composition.

\author{
Grain size (diameter) in millimeters
}

More than 0.125 (coarser than very fine sand)

0.125 to 0.062 (very fine sand)

0.062 to 0.005 (silt)

Less than 0.005 (clay)
Percentage

7.4

19.2

69.4

3.9

Clearly the formation should not be referred to as the Brule "clay," for only 4 percent or less of the materials comprising both samples are of clay size. The samples, analysis of which is given in the first table, were reported by Mr. Charles Milton to be composed of about $1 / 3$ volcanic ash, $1 / 3$ grains of calcium carbonate, and about $1 / 3$ miscellaneous minerals brought down from the mountains to the west. He refers to this sample as "drab, calcareous volcanic ash." The material, however, shows signs of extensive reworking. The sample from the ash bed is a high-grade volcanic ash, pumice, with a generous admixture of calcium carbonate crystals. The origin of the calcite may be secondary, but quite probably it was formed as the ash was accumulating; most of the other ash deposits taken from the Tertiary formations in western Nebraska alsocontain much calcite. The ash probably gathered in bodies of water where lime was being precipitated, or else in areas where ground water was being evaporated at the land surface. The mechanical composition. of the Brule resembles that of $a$ loess; $a$ fact that offers justification for believing that the Brule as a whole is an eolian deposit. Nevertheless, it is more probably an alluvial deposit, perhaps much reworked by wind.

The lower part of the Brule formation contains pale green silt, and channel sands are locally a prominent feature. The middle part of the formation, which includes all of that exposed on the bluffs at Scotts Bluff Monument, is mainly the typically massive, flesh-colored silt. 'The upper zone, seen only north of the North Platte River and in Banner County, is sandy and nodular. Most of the sand in this upper part is massive, but some shows lamination, and even cross bedding. The sandy upper part bears considerable resemblance to the lower part of the Arikaree group that overlies it. This classification is only general, and in no sense an attempt to formalize these slight lithologic differences in a very homogeneous formation.

Channel fills in the lower part of the Brule formation are not a common feature. Such a channel is well exposed, however, in gullies along the face of the third terrace, within sight of the highway on the north side of the river, east of Henry, in sec. 10 and 11, T. 23 N., R. $58 \mathrm{~W}$. The 
channel was cut into the Brule formation, for the southern edge of it is clearly visible. Green silt zones are associated with the flesh-colored Brule silt, suggesting that it is very low in the Brule section. Gray-green sandy silt, whose specific gravity is very low, is found below the channel deposits. This may indicate that the channel was cut clear through the Brule into the top beds of the Chadron formation. Within the channel 15 feet of hard, or medium hard, coarse, cross-bedded gray sand, containing much augite, hornblende, and magnetite, and in certain zones many clay balls, seems to rest on about 10 feet of silt of the Brule formation. Very hard ledges of sandstone appear in the section, but lens out in a short distance. This sandstone is only 15 feet north of the edge of the channel, and it dips northward about $5^{\circ}$. Sandstone a little farther north of the margin of the channel is essentially level. As the sandstone is traced toward the north it becomes finer in grain and more massive. The same sort of gradation takes place vertically up the section, the sandstone becoming more and more silty and massive until it merges finally into typical Brule, its color having imperceptibly changed from gray to brown to flesh. In another gully, about 100 yards to the northwest, a floor of gray-green silt is overlain by soft, gray, massive sandstone up to 15 feet thick, the top of this material being cut into by a lens of coarse, gray, cross-bedded fossiliferous sandstone. Silt of the Brule formation caps the channel. In several places in this gully the gradation of channel sand into typical Brule silt within a short distance (15 feet in one instance) is plain to be seen. The relations of the exposure suggest that the outside of a meander curve has been preserved, the coarse current deposits lying along the south bank of the stream, grading toward the inner side of the curve into finer and finer massive sand, thence into silt typical of most of the Brule formation. The exposure would be instructive to an investigator who is puzzled by the homogeneity of the Brule formation and its lack of depositional structures, and who may doubt that the Brule could be a stream-laid deposit.

A channel deposit is exposed in sec. 26 to 35 , T. $21 \mathrm{~N}$, R. $55 \mathrm{~W} .41 / 2$ miles south of Gering, east of the present highway. It is at an altitude of 4,030 to 4,100 feet above sea level. Thus, it corresponds in altitude to the lower part of the Brule exposed on the Scotts Bluff Monument, but is some distance above the zones containing green siltstone that are characteristic of the lower part of the Brule formation. However, test hole 22, drilled 4 miles west of this outcrop, encountered green silt, or clay, at 36 feet, and remained in that kind of material for the rest of the 27 feet of hole. This material is believed to be the Chadron, and if so, the channel is situated near the base of the Brule formation. Its age is without question Brule, for it contains siltstone pebbles of the Brule which must have been consolidated before they were rounded by stream wear. The sandstone in this channel fill shows lamination and cross bedding, but the sandstone is not so coarse as that in the other channel described, nor are the structures arising from current action so pronounced; the dominant color is brown. This deposit has a greater lateral and vertical extent. Pebbles and cobbles of Brule siltstone have weathered away from long-exposed outcrops, leaving prominent cavities. A zone of sandstone at the bottom of the exposed section, and one at the top of it are separated by 15 feet or so of siltstone of the usual Brule type, the sandstone making up the rest of the 70-foot gross thickness. 
The middle part of the Brule formation is well exemplified by the section exposed on the bluffs at Scotts Bluff Monument. The material there has been very little weathered, and as much as 200 feet of uniform, massive, structureless silt can be seen. At the north foot of Scotts Bluff Monument clay balls arranged in layers point to the incipient existence of bedding, but these are not common. A certain zoning can locally, be detected where slabby material alternates with more massive phases, but this aspect of the material represents a difference in response to the agents of weathering and is ordinarily not a feature of a very fresh exposure. Where the Brule has been weathered for some time it begins to break or split, first into slabs that run parallel to the exposed surface. Secondary breaks may eut across these at right angles, giving a blocky appearance to the material. Under most circumstances the exposure is not sufficient for this process to continue for long, but beneath the protecting terrace gravels on the north side of the river the Brule has been exposed for a long time: There the weathering structures are minute and intricate, and the material resembles a shale, so completely has it separated into slabs and blocks. Possibly incipient fractures, developed elastically after release of load, are being acted upon by percolating waters to produce this weathering structure. The fractures extend too far beneath the exposed surface to be caused by quick changes in air temperature', and certainly they are independent of any bedding. Some zones that weather into massive ledges, as in the badlands, are found to be more limy than are those zones that exhibit. spalling and fracturing. The lime may have been introduced by discharge and evaporation of ground water on old land surfaces.

Two or three ash beds are visible in the middle part of the Brule formation. They are not pure and are not separated from the surrounding material by a definite surface, but grade into it. On Scotts Bluff Monument two are exposed that are 1 foot to 3 feet thick.

The upper part of the Brule formation becomes more sandy, to the point of becoming a fine-grained, massive, soft sandstone. It possesses a vague nodular structure that resembles somewhat the poorly developed concretions of the lower zones of the Arikaree group. This sandy zone was eroded from the area about the Scotts Bluff Monument before the deposition of the Gering sandstone, but it is well developed south of Pumpkin Creek in the vicinity of Harrisburg in Banner County, where the top of the Brule is about 4,770 feet above sea level. At the Scotts Bluff Monument in the Wildeat Ridge south of Gering, the top of the Brule is about 4,360 to 4,400 feet above sea level, and the sandy zone is absent. North of Lake Minatare, however, the sandy zone is present at an altitude of about 4,360 feet, which may indicate a thickening of the zone toward the north, or possibly a slight dip. A few hundred feet south of the north-line road of sec. 27, T. 23 N., R. 53 W., a branch of Ninemile Creek has exposed a laminated zone which may be the boundary. between the siltstone and the sandstone of the upper part of the formation. It is about 160 to 180 feet below the Arikaree contact, at an altitude of about 4,120 feet above sea level, and consists of alternating layers of siltstone typical of the middle part of the Brule, and soft, gray, massive fine sandstone typical of the upper part. The layers are 3 to 6 inches thick, and a 20 -foot section is exposed. In the middle of the section is a 6-inch bed of ash. Some cross bedding is evident near the bottom of the section. So far as can be seen, all the Brule above this 
section is of the massive sandy type. It is not so nodular in this locality as it is in Banner County.

The materials of the Brule formation, consisting in Scotts Bluff County. chiefly of very fine sand and silt, do not yield water freely to wells. The sound, unleached material has a very low degree of permeability, and it is doubtful whether any significant quantity of water could be withdrawn by means' of wells 'were it not for the existence of fractures. These are widely distributed and numerous enough to permit small amounts of water to be obtained for stock and farm supplies over much of the county, but record was obtained of only one well that extracted a fairly large quantity of water from the Brule. This well, No. 305, in the NW $1 / 4$ NW $1 / 4$ sec. 13 , T. 20 N., R. 58 W., is about 80 feet deep, has a diameter. of 24 inches, and yields 500 gallons a minute. Other wells near it yield much less water. In some sections, as in the vicinity of Bald Peak 6 miles south of Morrill, wells drilled several hundred feet into the Brule failed to obtain any but a small supply, and some were failures. However, the Brule is the source of most of the farm and stock wells in the county. So far as is known, no wells intercepted a channel deposit of coarse material in the Brule formation.

\section{ARIKAREE GROUP}

Although the fine-grained brown to gray sandstone of Miocene age is a fairly homogeneous, mappable unit, detailed geologic and paleontologic work in western Nebraska and eastern Wyoming has demonstrated that the Arikaree can be divided into smaller mappable units. The stratigraphic usage that has evolved from these studies of the Miocene has been expressed by Lugn ${ }^{26}$ and by Schultz ${ }^{27}$. This classification has been based in part also on the consanguinity of faunal groups within various formations. The splitting of the Arikaree formation into three lithologic units, however, as described by Darton, is well authenticated by field evidence and by tradition. In Scotts Bluff County the Gering formation is readily distinguished from the rest of the Arikaree sandstones and will be discussed separately; but the two formations that overlie it, the Monroe Creek and Harrison, cannot readily be distinguished and will not be discussed separately but will be referred to merely as the upper formations of the Arikaree.

\section{GERING FORMATIOK}

The Gering formation is primarily a fine, soft, gray sandstone, strongly laminated and locally cross bedded. A sample of the material typical of much of the Gering above the basal sand was taken from the bluff at Scotts Bluff Monument, 10 feet above the lower limy ash bed and 30 feet above the Brule contact. A mechanical analysis in the hydrologic laboratory of the Geological Survey in Washington, D. C., showed the following distribution of grain sizes:

$\begin{array}{lc}\text { Grain size in millimeters } & \begin{array}{c}\text { Percentage } \\ \text { by weight }\end{array} \\ \text { More than } 0.125 \text { (coarser than very fine sand) } & 14.5 \\ 0.125 \text { to } 0.062 \text { (very fine sand) } & \\ 0.062 \text { to } 0.005 \text { (silt) } & \\ \text { Less than } 0.005 \text { (clay) } & \end{array}$

${ }^{28}$ Lugn; A. L., Classification of the Tertiary system in Nebraska: Geol. Soo. America Bull., vol. bo, pp. 1245-1276, 1989 .

g7 Schultz, C. B, The Miocene of western Nebraska: Am. Jour. Sci., bth ser., vol. 35, pp. 441-444; 1938', 
Very coarse material is scarce in the exposures in the county, and in the more massive facies it is certain that silt becomes a still more prominent constituent.

The Gering formation occupies a channel cut into the upper surface of the Brule formation. From a maximum thickness of about 200 feet, 6 miles south-southwest of the city of Gering, it thins to a knife's edge toward the south and southwest and toward the north and northeast. (See pl. 2.) It has not been mapped on the south side of the western end of Wildcat Ridge nor on the bluffs north of the river, but Darton considers that it exists there as an undifferentiated zone at the base of the Arikaree. It crops out continuously along the north face of Wildcat Ridge, on the bluffs surrounding Cedar Valley, on the massif that includes the Scotts Bluff Monument and nearby bluffs, and in the vicinity' of'Signal Butte. From there the outcrop continues toward the southwest and pinches out just north of the county line. It appears in the southwestern corner of Sioux County. The southern margin of the formation trends somewhat more toward the northwest than do the valleys of the North Platte River and Pumpkin Creek, and cross cuts obliquely the ridge between them.

Three sections are given to illustrate the nature of the sediments that make up the Gering formation. The first two were described by Darton ${ }^{27 a}$.

\section{Section of Gering formation 6 miles south-southwest of Gering}

Gray sandstone with pipy concretions, of the upper beds of the Arikaree group.

Sand and pebbles.

Feet ,

Unconformity.

Massive buff sand.

Sand, pebbly below, fine above.

Pure volcanic ash

Sand and pebbles.

Unconformity.

Pink sandy clay.

Pink sand and clay.

Coarse sand.

Unconformity.

Brule formation:

Section of Gering formation on north face of Scotts Bluff

Gray sands.

Feat

Volcanic ash

Unconformity.

Brule formation.

The bedding exhibited by the Gering in this locality is rather fine in scale, regular in most places, but contorted near the base. The surface on which the lowest sands rest is, in small scale, very uneven, and the

\footnotetext{
wa Darton, N. H., Proliminary report on the geology and water resources of Nebraplsa west of the $109 \mathrm{~d}$ meridian: U. S. Geol. Survey Prol. Paper 17, pp. 33, 38, 1903.
} 
bedding follows it. However, some of the laminae, 1 to 3 inches thick, show ripple marks. 'Locally near the top long sweeping cross-bedded layers suggest dune bedding. Elsewhere in a few spots small-scale, choppy cross bedding typical of an alluvial deposit may be seen. Two thin layers of white friable limestone stand out in the section because of their contrast with the gray sand. On examination in the chemical laboratory of the Geological Survey they proved to consist of shards of more or less altered volcanic glass, quartz, feldspar, basaltic hornblende, and other igneous minerals in a fine-grained, calcareous matrix. Along the highway south of Crawford, Dawes County, near the foot of Bryan Canyon, layers of greenish-white diatomaceous earth containing bentonite can be found in the Gering sands. This material, which was deposited in a shallow body of still water, may have been altered and then later calcified by percolating ground water into the state in which it is found at Scotts Bluff. Samples of similar material found in other beds of the Tertiary formations in the region seem to be infused with opaline silica that radiates from focal points, usually microfossil shells, until it replaces all of the limy, ashy substance. Where fresh, it is pale green, but it weathers white. Manganese dendrites permeate it. The material is locally called agate. It is found in many places in close association with unconformities, or else in channel deposits.

\section{Section of Gering formation at Signal Butte}

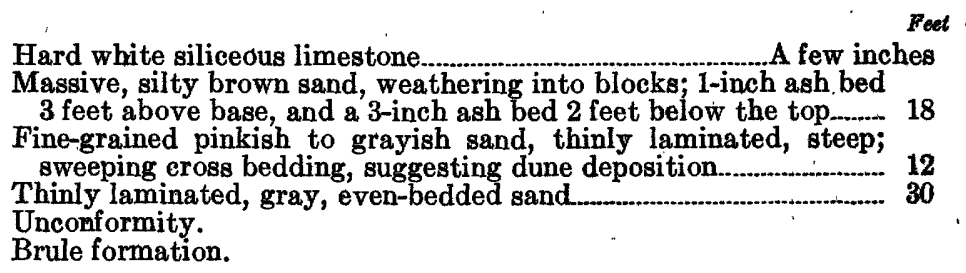

At Scotts Bluff and certain other places the pipy coneretions that are so characteristic of the upper formations of the Arikaree are present in the upper part of the Gering, though feebly developed, small, and sparsely scattered.

The fine, well-sorted sands of the Gering are permeable, and where a sufficient thickness of the formation is saturated they yield copious amounts of water to properly constructed wells. In Scotts Bluff County, however, much of the Gering is not saturated, and, further, it underlies the rugged tablelands south of the river. Because of its unfavorable topographic situation, it is of little hydrologic importance.

\section{UPPER SANDSTONES OF THE ARIKAREE GBOUP}

These formations that overlie the Gering and cap most of the upland areas (see pl. 2) are massive, brown-gray ranging upward to gray, silty to well-sorted, fine sandstone. They are not highly indurated except in certain zones where they are concretionary. Whereas the Brule and Gering crop out along the margins of the uplands to form steep bluffs, the upper sandstones of the Arikaree typically slope back from the edges of the bluffs at rather low angles, and thus are not so well exposed except in certain localities where erosion has been especially active. Conglomerates are associated with the fine sandstone in some places. The 
outstanding characteristic of these formations is the presence of concretions that are disposed and distributed throughout the formations with a certain regularity. Besides these, seams of light gray or white lime, and limy roots and stems are abundant in the sandstones.

The following is a mechanical analysis of a sample of the upper sandstone of the Arikaree, made in the hydrologic laboratory of the Geological Survey in Washington, D. C. The sample was taken from the face of the bluff at Scotts Bluff Monument.

Grain size (diameter) in millimeters
More than 0.125 (coarser than very fine sand)

Almost 90 percent of the sample was very fine sand and silt. To the touch the sand is gritty, but a dusty residue of silt will cling to the hand.

A few beds of ash occur in the upper sandstones of the Arikaree; one is exposed on the bluffs at Scotts Bluff Monument.

Two types of conglomerate are associated with these sandstones. One of them is extensively developed and distributed in the Goshen Hole district of Wyoming. It consists of crystalline rock and chert pebbles brought in from the Rocky Mountains and deposited by streams. 'Farthest west the conglomerates occur near the base of the Arikaree, but toward the east they occur farther and farther up in the formation, suggesting an overlap as the formation was built tip ${ }^{28}$. The type of conglomerate that is found in Scotts Bluff County is composed of large and small fragments of pipy concretions that were eroded from their parent sandstones and deposited in channels that had been cut into the Arikaree 'sandstones. In some, places these channels are capped with typical sandstone of the Arikaree. Darton has described the mode of occurrence and distribution of these conglomerates in considerable detail. This type of conglomerate represents brief but violent periods of stream erosion and deposition during the course of the building up of the Arikaree sandstones.

Concretions in the Arikaree sandstones are of two kinds. North of the river they are small and round, resembling potatoes in size and shape. Those on the south side of the river are elongated, lying prone, and aligned in a west-southwest direction. They look like posts, ranging in length from a few inches to as much as 10 feet, and in diameter from 1 to perhaps 6 inches. They are small and sparsely scattered in the lowest zones of the upper sandstones of the Arikaree and in the Gering formation. Upward they become more numerous and larger, and coalesce to form continuous layers which become thicker and closer together. Where they have coalesced, however, they have not lost their pipy character. They are solidly cemented with lime, are hard, and impart to the formation as a whole its resistance to erosion. Along the fresh cut where the road is being constructed to the top of the Scotts Bluff Monument, details of the pipy concretions were observed, 'as follows:

1. Those concretions that occur in a zone where others are numerous are likely to be flattish or lens-shaped.

2. Where a group of concretions occur along a definite horizontal zone, a.lime-filled seam is likely to be found connecting them and ex-

\footnotetext{
${ }^{29}$ Adams, G. I., Geology and water resources of the Patriek and Goshen Hole Quadranglea: U. B. Geol:
} Sarvey Water-Supply Paper 70, 60 pp:, 1902. 
tending beyond the cluster; root holes filled with lime are associated with this seam. It is not strictly horizontal in all places, but may slope, suggesting the top of a cross-bedded lamination or the bottom of a channel.

3. In some places a group of concretions are scattered along a zone that 'undulates.

4. Some concretions occur singly, others in a zone offset from another concretionary zone. Few of these zones persist very far in a horizontal direction without such offsets. However, these observations were made in the lower part of the Arikaree section; the concretionary zones are more persistent farther up.

5. Between the concretion proper and the surrounding sand is a ring of gray limy sand, softer than the material comprising the concretion. Also, some concretions are tubular, and the centers are filled with this same soft gray limy sand. Moreover, this sand forms imperfect rather irregularly shaped, but roundish concretions scattered sparsely through the formation.

6. Between the gray limy sand and the whitish edge of the concretion proper may be a ring of dark brown sand containing little or no lime.

7. The margin of the hard concretion is white, and forms a definite surface. It is particularly sharp at the top and bottom of the concretions:

8. In some cases bedding can be seen to cut through the concretion and conform to the bedding in the matrix. The sand in the concretion proper is similar in grain to that of the matrix.

Unfortunately, these detailed obserwations do not lead to a detailed explanation of the way in which the pipy concretions were formed. Certainly the lime was concentrated after the sandy matrix was laid down, but since the conglomerate of the Arikaree is made up of pipy concretions and their fragments, they must have been essentially native to the formation during its construction. Thus they seem to appertain to the physical environment prevailing during the time the Arikaree was being deposited.

North of the river the concretions are of the "potato" type. Near the base of the Arikaree isolated lumps of them are scattered more or less uniformly. The potatolike concretions are not definitely set apart from the matrix sands; rather they are menely harder lumps of it. Upward they show an increasing tendency to gather into layers. which are only 5 to 20 feet apart. Above a layer the concretions are scarce; they become increasingly numerous, but are distributed at random until they coalesce to form another solid layer. The lower surfaces of the layers are irregular, rather indefinite, and lumpy; their top surfaces are horizontal, definite, and sharply delimited from the matrix above, but they are likely to be somewhat wavy. They become thicker and closer together upward in the formation. A well-developed layer will be about 1 to 3 feet thick.

It seems to be in the broad geographical relationship of the two chief kinds of concretions that their general significance may be seen. The Miocene sediments were deposited in a basin whose southern limit was not far south of the southern rim of Pumpkin Creek Valley, and whose northern limit lay at some point south of the Black Hills. The pipy concretions near the northern limit of the Miocene basin are aligned toward the northwest and southeast, whereas those in Scotts Bluff County are aligned toward the southwest and northeast; in other words, they point' toward the axis of the Miocene basin with a component down-stream: 
This suggests that ground water, slowly migrating inward from the edges of the basin but also downstream, may have caused the elongation of the concretions into their pipy shape. In the axial regions of the Mioeene basin the concretions are round, or, if elongated, are elongated vertically. This suggests the action of descending or ascending water; the irregular lower surface of the coalesced layers of the potatolike concretions suggests that the lime was carried and deposited by descending water. Water falling on the land surfaces beyond the limits of the Miocene basin might have passed beneath the surface and entered the rather impermeable silts of the Brule formation, and the water table would slope steeply toward the axis of the basin near the margins of the more permeable Miocene sands. This might have induced a somewhat more constant, and perhaps more vigorous, movement of the ground water in the peripheral regions of the Miocene basin than took place near the axis. Beneath the floodplain, over which streams wound and shifted, the direetion taken by the ground water would have been less definite and constant.

On the table lands of Sioux and Box Butte counties the sandstones of the Arikaree group yield moderately large amounts of water to wells that penetrate a great thiekness. But in Scotts Bluff County the Arikaree underlies lands that are undesirable for farming, and especially for irrigation. Hence, these fine sandstones are of little importanee as sourees of ground-water supply.

\section{QUATERHARY SYSTEM}

\section{SAND AND GRÁEEL}

Highly permeable sand and gravel have been distributed systematically in the inner valley of the North Platte in the manner discussed under the heading of land forms. Where they are thick enough, large quantities of water may be extracted from them with properly equipped wells. Thick deposits of sand and gravel may be found almost exclusively in the channels cut during the $3 \mathrm{a}$ stage of the development of the valley, both by the river and by tributaries entering it from the north. Hence, they are to be looked for in the axial part of the inner valley, and on the broad third terrace north of the river, known variously as Dutch Flats, Tabor Flats, Highland Flats, and the Bayard Terrace. The contours of the bedrock surface in plate 1 show the approximate location, width, and depth of these gravel-filled channels.

\section{OCGURRENCE OF GRÓUND WATER}

Beneath the surface of the earth is the zone of saturation. In it the pores, cracks, and crevices in the rocks are filled with water under hydrostatic pressure. This water is called ground water, and its upper-surface is known as the water table. The depth of the water table below. the land surface and the thickness of the zone of saturation differ greatly in different localities. In some areas the zone of saturation is overlain by a relatively impervious formation, which confines the ground water under pressure. Water confined beneath an impervious formation under pressure is called artesian water. In some areas water is suspended above the main water table because of a relatively impervious bed that hinders the downward movement of the water to such an extent that it forms an upper zone of saturation known as perched water. 
Ground water in Scotts Bluff County occurs chiefly in three-waterbearing formations, Pleistocene and Recent sand and gravel, the Brule formation of Tertiary age, and the Lance formation of Cretaceous age. These formations, described on preceding pages, differ greatly in character and therefore in water-bearing properties.

\section{PLEISTOCENE AND RECENT SAND AND GRAVEL}

The Pleistocene and Recent sand and gravel occur chiefly as thick heterogeneous deposits of permeable water-bearing material beneath the bottom lands along the North Platte River and beneath parts of the third terrace north of the river. These deposits constitute the fill in old channels (pl. 1) that the Platte and its northern tributaries cut in the Brule formation, probably during the $3 \mathrm{a}$ stage of the development of the valley. (see pp. 39-40). Deposits of Pleistocene and Recent sand and gravel are found as a general cover on the terraces north of the river, but in most places they are much thinner than the channel deposits. The thickness of the fill in the channels is as much as 200 feet, whereas the mantling terrace deposits are mostly less than 20 feet thick. Almost no related sand and gravel deposits occur in the county south of the North Platte River.

Wells that draw water from the sand and gravel in the old channels commonly yield 1,000 gallons or more a minute. Almost all the wells pumped for irrigation, industrial, and municipal supply tap this productive channel fill, and are therefore situated along the bottom lands of North Platte River, or on the third terrace north of the river in areas known variously as Dutch Flats, Tabor Flats, Highland Flats, and Bayard Terrace. The gravels that mantle the terrace surfaces, although widespread on the north side of the valley, yield only small quantities of water to wells because of the limited thickness of the deposits. Water in the Pleistocene and Recent sand and gravel is not believed to be confined under artesian pressure.

\section{BROLE FORMATION}

The Brule formation, although much less productive than the Pleistocene and Recent sand and gravel, is the source of supply for most of the wells in the county, chiefly because it is the most extensive aquifer that lies at or near the surface in the area. The materials composing the Brule, mostly very fine sand and silt, are relatively impermeable, both individually and in the aggregate. In Scotts Bluff County the Brule formation as a whole, however, has a considerably higher permeability than its constituents, because of the fissures and cracks through it which in some places extend to considerable depth. These openings in the Brule generally contain water and in most places in the county yield sufficient water to wells for domestic and stock use. The productivity of the formation, however, differs considerably from place to place, depending on the amount of recharge and the number, size, and continuity of the cracks. In the vicinity of Bald Peak in southeastern Scotts Bluff County, wells obtain only very meager supplies or none at all from the Brule; whereas in the southwestern part of the county, in the NW1/4 NW1/4 sec. 13, T. 20 N., R. 58 W.; an irrigation well obtains 500 gallons a minute. The yield of this well is exceptionally high, how- 
ever, in comparison with that of most wells penetrating the Brule; that of other wells nearby is much less. In general the water supply of the Brule formation is greatest in that part of the county lying below the irrigation canals where the zone of saturation receives large accretions by seepage from canals and irrigated fields, and it is least in the higher parts of the county where the chief source of recharge is the precipitation.

In the Brule formation water is recovered by wells almost entirely from cracks and fissures, but it is not to be inferred that the consolidated material of the formation contains no water. On the contrary, such material throughout the county probably contains much more water than do all the openings. The average porosity of two samples of Brule was determined in the laboratory of the Geological Survey in Washington, D. C., to be 52.5. This indicates that each cubic foot of consolidated material in the zone of saturation may contrin 0.525 cubic foot of water. Wells that do not penetrate cracks in the Brule in Scotts Bluff County may fail, not because the formation is barren of water at that place, but because the permeability of the consolidated material is so low that water does not percolate through it to wells as fast as it is withdrawn, even though the rate of pumping may be extremely low. Thus, there may still be a zone of saturation in the Brule in areas where wells do not produce adequate supplies. In such areas the wells, if allowed to remain open, will slowly fill with water to the level of the water table, or where artesian conditions exist, to the level of the piezometric surface. ${ }^{29}$ Subsequent pumping will cause the wells to go dry almost as soon as the water in the casing has been removed, and the wells will fill again only after a considerable period of idleness.

Although water in the Brule formation occurs mostly under water-table conditions, in a few places in Scotts Bluff County it is confined under pressure and rises in wells above the level at which it is struck. In one locality about 13 miles south of Mitchell, in sec. 10, T. 22 N., R. 56 W., the water in the Brule is under sufficient head to cause wells to flow: Here three seepage wells (well F-5, F-6, and F-7) drilled to a depth of 110 feet, produce a combined flow of about 900 gallons a minute. The artesian head in the Brule, however, is generally sufficient to cause the water to rise in wells only a few feet above the zone of saturation. It is believed that this artesian pressure, where encountered, is essentially a local feature, caused by the presence of cracks and fissures in a zone above which the character of the formation is locally massive and tight, thus providing a confining layer, and the interconnection of the openings beneath the massive part of the Brule with those in some nearby locality where the water table stands at a relatively high altitude.

Much of the discussion in this report is based on data gathered by a canvass of the wells of the county. As practically all the wells in the Brule formation tap water in cracks and fissures, it is evident that the data obtained from such wells relate chiefly to the occurrence of water in the open part of the formation and only to a small degree to the consolidated part. Unless otherwise stated, therefore, data and discussion given here relate to the open part of the formation.

20 The piezometric aurface of an aquifer is the imaginary surface that everywhere coincides with the hegd. of the water in the aquifer. See Meinzer, O. E., Outline of ground-water hydrology, with definitions: U. S. Geol. Survey Water-Supply Paper 494, p. 38, 1923. 


\section{LATCE FORMATION}

In Scotts Bluff County the Lance formation, which consists chiefly of clay and sandstone, appears at the surface at only two isolated localities near Lyman (pp. 53-59) and is buried beneath the younger sediments or is absent at other places. Where penetrated by wells, the sandstone beds of the Lance usually yield small quantities of artesian water, as in an ares south of Lyman where about 30 small-diameter wells obtain flows ranging from a trickle up to slightly more than a gallon a minute. Although the flow of these wells is small, it is apparently constant throughout the year, and hence constitutes a supply for most domestic and stock purposes,

Wells drilled into the Lance at Scotts Bluff and Gering also encountered water under pressure. These wells, no longer in use, were of larger diameter than those in the western part of the county, and it is reported that they yielded flows of as much as 25 gallons a minute. The overlying impermeable Chadron formation probably confines the water in the Lance under pressure by preventing appreciable upward movement to the surface.

\section{HYDROLOGIC PROPERTIES OF THE WATER-BEARING FORMATIONS}

\section{GENERAI CONDITIONS}

The quantity of ground water that a water-bearing material will yield to wells or other recovery devices depends principally upon certain hydrologic properties of the material. These properties vary greatly, even where differences in the texture of the material are apparently only slight, and hence quantitative determinations of them are desirable.

The two hydrologic properties of greatest significance are permeability and specific yield. Permeability is a measure of the ability of a material to transmit water; specific yield is a measure of the quantity of water that a formation will yield when it is drained. Permeability may be expressed as a coefficient, defined as the number of gallons of water a day, that would be conducted, if the water temperature were $60^{\circ} \mathrm{F}$., through each mile of water-bearing bed under investigation (measured at right angles to the direction of flow), for each foot of the thickness of the bed and for each foot per mile of hydraulic gradient. It may also be expressed as a field coefficient of permeability, defined as the number of gallons of water a day that percolates under prevailing conditions through each mile of water-bearing bed under investigation (measured by right angles to the direction of flow), for each foot of thickness of bed and far each foot per mile of hydraulic gradient. ${ }^{30}$

Specific yield of a water-bearing material is defined as the ratio of (1) the volume of water that, after being saturated, it will yield by gravity to (2) its own volume. ${ }^{31}$. The quantity of water that will percolate through a given cross section of water-bearing material under a known hydraulic gradient is directly proportional to the field coefficient of permeability of the material. The quantity of water that will be yielded for each foot of decline of the water table, or that is represented by each foot of rise of the water table, is directly proportional to the specific yield.

30 Wenzel, L. K., Methods of determining the permeability of water-bearing materials, with wpecinl reterence to field discharge methods: U. S. Geol. Survey Water-Supply Paper 867, p. 7, 1942.

"Meinzer, 0 . E., Outline of ground-water hydrology, with definitions: U. S. Geol. Survey Water-Bupply to Paper 404, p. 28, 1923. 
In connection with this investigation a pumping test was made southeast of Mitchell to determine the permeability of the Pleistocene and Recent sand and gravel, and samples of the Lance and Brule formations were sent to the hydrologic laboratory of the Geological Survey for analyses of their hydrologic properties. The samples of Lance disintegrated on being saturated with water and it was not possible to determine either the permeability or specific yield. Satisfactory determinations were made, however, on the samples of Brule. No determinations were made of the hydrologic properties of the Chadron and Gering formations or of the upper sandstones of the Arikaree group, because they are not significant as water-producing formations in Scotts Bluff County.

\section{PLEISTOCENE AND RECENT SAND AND GRAVET}

The pumping test to determine the permeability and specific yield of the Pleistocene and Recent sand and gravel was made on the farm of Harry Pieper, in the NW $1 / 4$ SE1 $1 / 4$ sec. 11, T. $22 \mathrm{~N}$., R. $56 \mathrm{~W}$., on the south side of the North Platte River about 6 miles west of Scottsbluff and 4 miles south of Mitchell. An existing irrigation well (No. 195) 24 inches in diameter and 46 feet deep was employed for withdrawing water from the formation; and 17 observation wells $11 / 4$ inches in diameter and about 23 to 29 feet deep were constructed in a straight line through, and at varying distances from, the irrigation wells (see accompanying table), in order that the fluctuations of the water table resulting from the pumping might be observed. The irrigation well was pumped continuously at a rate of about 1,270 gallons a minute from $11: 53$ a. m. Nov. 2 to $3: 32$ a. $\mathrm{m}$. Nov. 3,1937 , during which time measurements of the water levels in the observation wells were made periodically. The lowering of the water table after 10 and 15 hours of pumping is shown in the table on p. 80. The regular measuring of water levels in the wells was continued until about noon November 4 , in order that observations might be obtained on the subsequent rise of the water table resulting from the cessation of pumping.

Location, diameter, depth, and altitude of wells used in the pumping test on the form of Harry Pieper, near Scottsbluff, Nebr.

\begin{tabular}{|c|c|c|c|c|c|}
\hline $\begin{array}{l}\text { Pumped well and } \\
\text { distanoe of teat wells (feet) }\end{array}$ & $\begin{array}{c}\text { Diameter } \\
\text { (inches) }\end{array}$ & $\begin{array}{c}\text { Depth below } \\
\text { measuring point } \\
\text { (feet) }\end{array}$ & $\begin{array}{c}\text { Distance of } \\
\text { measuring point } \\
\text { above land surface } \\
\text { (foet) }\end{array}$ & $\begin{array}{l}\text { Altitude of } \\
\text { measuritis point } \\
\text { above asotumed } \\
\text { datum (feet) }\end{array}$ & $\begin{array}{l}\text { Distance } \\
\text { from anilo } \\
\text { of pemped } \\
\text { well (feet) }\end{array}$ \\
\hline 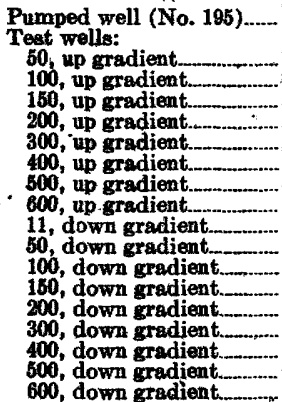 & 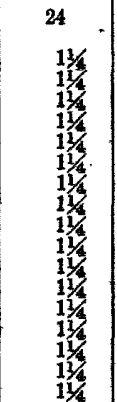 & $\begin{array}{l}46.4 \\
28.4 \\
23.4 \\
23.0 \\
23.5 \\
23.4 \\
23.1 \\
23.4 \\
23.6 \\
28.3 \\
28.9 \\
23.3 \\
23.5 \\
23.5 \\
23.1 \\
23.1 \\
23.3 \\
23.2\end{array}$ & $\begin{array}{l}0.8 \\
1.2 \\
1.2 \\
1.4 \\
1.1 \\
1.1 \\
1.4 \\
1.4 \\
.4 \\
1.4 \\
1.4 \\
1.2 \\
1.5 \\
1.7 \\
1.7 \\
1.4 \\
1.4\end{array}$ & $\begin{array}{l}50.28 \\
49.98 \\
50.20 \\
50.18 \\
50.28 \\
50.07 \\
50.21 \\
50.68 \\
51.28 \\
49.98 \\
50.62 \\
50.65 \\
60.39 \\
50.78 \\
50.93 \\
50.96 \\
50.79 \\
51.00\end{array}$ & 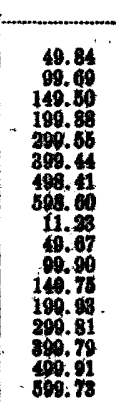 \\
\hline
\end{tabular}


Draw-down of the water table, in feet, in the pumping test on the farm of Harry Pieper near Scottsbluff, after 10 and 15 hours of pumping, at several distances"up-gradient and down-gradient from the pumped, well.

\begin{tabular}{|c|c|c|c|c|c|c|}
\hline \multirow{2}{*}{$\begin{array}{l}\text { Distance up gradient } \\
\text { from pumped well } \\
\text { (feet). }\end{array}$} & \multicolumn{2}{|c|}{ Draw-down (feet) after- } & \multirow{2}{*}{\multicolumn{2}{|c|}{$\begin{array}{l}\text { Distance down-gradient } \\
\text { from pumped well } \\
\text { (feet) }\end{array}$}} & \multicolumn{2}{|c|}{ Draw-down (feet) after- } \\
\hline & 10 hours & 15 hours & & & 10 hours & 15 hours \\
\hline $\begin{array}{r}50 \\
100 \\
150 \\
200 \\
300 \\
400 \\
500 \\
600\end{array}$ & $\begin{array}{l}6.56 \\
4.73 \\
3.90 \\
3.42 \\
2.71 \\
2.21 \\
1.85 \\
1.54\end{array}$ & $\begin{array}{l}6.69 \\
4.87 \\
4.03 \\
3.55 \\
2.86 \\
2.36 \\
1.99 \\
1.67\end{array}$ & $\begin{array}{r}50 \\
100 \\
150 \\
200 \\
300 \\
400 \\
500 \\
600\end{array}$ & . & $\begin{array}{l}6.81 \\
4.57 \\
3.77 \\
3.22 \\
2.44 \\
1.88 \\
1.44 \\
1.20\end{array}$ & $\begin{array}{r}6.93 \\
4.73 \\
3.98 \\
3.40 \\
2.61 \\
2.06 \\
1.62 \\
1.36\end{array}$ \\
\hline
\end{tabular}

The general procedure for the pumping test was developed from a similar though much more elaborate test ${ }^{32}$ made in 1931 near Grand Island, Nebr. The same procedure was successfully employed in 1933 at two other locations in the Platte Valley, near Kearney and near Gothenburg, during the course of the investigation of the geology and ground-water resources of south-central Nebraska. ${ }^{33}$ Recently a report ${ }^{34}$ devoted largely to a description of pumping-test methods has been established. This paper includes the water levels in observation wells for the tests at Grand Island, Kearney, and Gothenburg, and also those made in connection with the pumping test at the Pieper farm, referred to in that report as the Scottsbluff test. The paper. also contains computations of permeability by several different methods for all the tests, and computations of specific yield for the Grand Island and Scottsbluff test.

The permeability of the Pleistocene sand and gravel at the Pieper farm was computed from the data collected in the pumping test by the following formulas: limiting formula, gradient formula, nonequilibrium. formula, and recovery formula.

The limiting formula is written

$$
\mathrm{P}_{f}=527.7 q C
$$

in which $\mathrm{P}_{f}$ is the field coefficient of permeability, expressed in Meinzer's units; $q$ is the discharge of the pumped well, in gallons per minute; and $C$ is a constant, equal to $\frac{\mathrm{A}}{B}$, which is determined graphically. $A$ is
equal to

$$
\frac{\log _{10} \frac{r_{2}}{r_{1}}}{0.25 M}
$$

and $B$ is equal to $1 / 2\left(s_{1 u}+s_{1 d}-s_{2 u}-s_{2 d}\right)$, where $r_{1}$ and $r_{2}$ are distances, in feet, to two points on the cone of depression lying on a straight line

\footnotetext{
:2 Wenzel, L. K. Recent investigations of Thiem's method for determining permeability of water-bearing materials: Am. Geophys. Union Trans. 13th Ann. Meeting, pp. 313-317, 1032. Wenzel, L. K., Specifie yiald determined from a Thiem's pumping test: Am. Geophys. Union Trans, 14th Ann. Meeting, pp. 475-477, 1033. Wenzel, L. K.. The. Thiem method for determining permeability of water-bearing materials and its application to the determination of specific yjeld: U. S. Geol. Survey Water-Supply Paper 679-A, 1936.

sa Lugn, A. L., and Wenzel, L. K., Geology and ground-water resources of south-central Nebraska, with speoial reference to the Platte River Valley between Chapman and Gothenburg: U. S. Geol. Survey WaterSupply Paper 779, pp. 100-105, 1838.

$\mathcal{u}$ Wenzel, L. K. Methods for determining the permeability of water-bearing materials, with specia reference to field diseharge mothods: U. S. Geol. Survey Water-Supply Paper 887, pp. 1-192, 1942.
} 
through the pumped well; s st is the draw-down of the water level, in feet, on the line at the distance $r_{1}$, up gradient from the pumped well; $s_{1 d}$ is the drawn-down, in feet, at the distance $r_{1}$, down gradient from the pumped well; $s_{2 u}$ is the draw-down, in feet, at the distance $r_{2,}$ up gradient; $s_{2 t}^{\prime}$ is the draw-down, in feet, at the distance, $r_{2}$ down gradient from the pumped well; and $M$ is the sum of the saturated thicknesses of water-bearing material, in feet, at $r_{1 u}, r_{1 d}, r_{2 n}$, and $r_{2 d}$. To obtain $C$ in the formula, all possible values of $A$ are plotted against corresponding values of $B$, and a straight line is drawn through the points and the origin. $C$ is equal to the slope of the straight line.

The gradient formula is written

$$
P_{f}=\frac{18,335 q}{r\left(h_{u}+h_{d}\right)\left(f_{(r+10) u}+f_{(r+10) d}-f_{(r-10) u}-f_{(r-10) d}\right)}
$$

where $P_{f}$ is the field coefficient of permeability, expressed in Meinzer's units; $q$ is the discharge of the well, in gallons per minute; $r$ is the distanice from the pumped well to a point on the cone of depression, in feet; $h_{u}$ is the saturated thickness of water-bearing material, in feet, at the distance $r$ up gradient from the pumped well; $h_{d}$ is the saturated thickness of " water-bearing material at the distance $r$ down gradient; $f(r+10)$, is the altitude, in feet, of the water table at distance $r+10$ feet up gradient from the pumped well; $f(r+10) d$ is the altitude of the water table, in feet, at distance $r+10$ feet down gradient; $f(r-10)$ is the altitude of the water table, in feet, at the distance $r-10$ feet up gradient; and $f(r-10) d$ is the altitude of the water table at distance $r-10$ feet down gradient from the pumped well.

The nonequilibrium formula ${ }^{85}$ is written:

$$
P_{f}=\frac{114.6 q}{s m} \int_{u}^{\infty} \frac{e^{-u} d u}{u}
$$

where $P_{f}$ is the field coefficient of permeability, expressed in Meinzer's units; $q$ is the discharge of the pumped well, in gallons per minute; $s$ is the draw-down of the water level, in feet; $m$ is the thickness of saturated water-bearing material, in feet; $u=\frac{1.87 r^{2} S}{P_{f} m t} ; r$ is the distance, in feet, to the point on the cone of depression at which the draw-down $s$ is measured; $S$ is the coefficient of storage of the water-bearing material (cubic feet of water discharged from each vertical column of the aquifer with base 1 foot square, as the water level drops 1 foot) expressed as a decimal fraction; and $t$ is the time the well has been pumped, in days. The

integral $\int_{u}^{\infty} \frac{e^{-u} d u}{u}$ may be evaluated by the following series:

$$
0-.577-\log _{\mathrm{e}} u+u-\frac{u^{2}}{2 \cdot 2 !}+\frac{u^{3}}{3 \cdot 3 !}-\frac{u^{4}}{4 \cdot 4 !} \cdot \text {. }
$$

25 Theis, C. V., The relation between the lowering of the piesometric surface and the rate and duration of discharge of s well using ground-water storage: Am. Geophys. Union Traps., pp. 619-824, 1085. 
The nonequilibrium formula cannot be solved directly for the coefficient of permeability because this factor appears on both sides of the equation. The formula is usually solved by a graphical method described on pages. 88-89 of Water-Supply Paper 887.

The recovery formula, with an empirical correction, is written:

$$
P_{f}=\frac{264 q}{s m} \log _{10} \frac{t \pm c}{t^{\prime}}
$$

where $P_{f}$ is the field coefficient of permeability; expressed in Meinzer's units; $q$ is the discharge of the pumped well, in gallons per minute; $s$ is the residual draw-down, in feet, in the pumped well at time $t^{\prime}$, in days, after the pump has stopped operating; $m$ is the saturated thickness of water-bearing material; $t$ is the time, in days, since pumping began; and $c$ is a correction factor that may be applied at the discretion of the investigator. Values of $\log \frac{t}{t^{\prime}}$ are plotted against $s$ and a straight line drawn through the origin. If the line does not pass through the origin, it has been found necessary to plot $\frac{t \pm c}{t^{\prime}}$ against $s$ in order to obtain consistent results, the value of $c$ being chosen so that the straight line through the plotted points will also pass through the origin. The slope of the straight line is substituted in the recovery formula for $\frac{\log 10 \frac{t \pm c}{t^{\prime}}}{8}$.

Computations by the four methods give the following values 96 for the field coefficient of permeability of the Pleistocene and Recent sand and gravel; limiting formula, 1,427; gradient formula, 1,423; nonequilibrium formula, 1,370; and recovery formula, with empirical correction, 1,373. The average of these values is 1,398 .

It is possible by the use of the nonequilibrium formula to compute the specific yield of the material unwatered during a pumping test. ${ }^{37}$. At the Pieper farm the permeable sand and gravel is overlain with a much less permeable material consisting largely of fine sand and silt, and the decline of the water table during the pumping test occurred in this finegrained material. The specific yield computed from the test is, therefore, that of the fine-grained material, and not that of the more permeable sand and gravel through which most of the ground-water movement. takes place.

The specific yield of the material unwatered during the test on the Pieper farm was computed for three periods of pumping. After 4 hours of pumping, the computed specific yield was 0.97 percent; after 8 hours, 1.4 percent; and after 15 hours, 1.8 percent. The gradual increase in the values is caused by the slow draining of the material. The ultimate specific yield that would be reached after a much longer period of draining is probably much greater than that reached at the end of 15 hours.

Wenzel, L. K., op. cit., pp. 137-41.

87 Wenzel, L. K., op, cit., p. 89. 


\section{BRUIE FORMATION}

The coefficient of permeability of a sample of typical Brule, taken from a fresh road cut on the face of Scotts Bluff monument halfway between tunnels Nos. 1 and 2 , and 140 feet below the contaet with the Gering formation, was determined in the hydrologic labioratory of the Geological Survey to be 4 . Another sample, taken at the lower portal of tuninel No. 2 had a coefficient of permeability of 7 . This means that 4 or 7 gallons a day of water at $60^{\circ} \mathrm{F}$. would percolate through a èross section: 1 mile wide and 1 foot thick under a hydraulic gradient of 1 foot to the mile. It is evident that where the Brule formation as a whole is no more permeable than its constituent materials, the discharge through it is slight, even where the formation is thick. The cracks and fissures, however, that occur in the Brule at most places in Scotts Bluff County greatly increase the permeability of the formation, the degree of this. increase depending on the number, size, and interconnection of the openings. Because their character differs so greatly from place to place, it is difficult to determine the effect of these openings on the permeability of the formation as a whole.

A rough concept of the increase in permeability that may be caused by presence of small openings in a relatively impermeable formation may be had by assuming that the flow through the openings is comparable to the flow of water through pipes.

Turneaure and Russell ${ }^{38}$ give the following formula for the velocity of water through old tuberculated cast-iron pipe:

$$
v=55 d^{.68} s .54
$$

where $v$ is the velocity, in feet per second; $d$ is the diameter of the pipe, in feet; and $s$ is the slope (loss of head) of the pressure gradient, in feet per 1,000 feet.

The flow through a pipe $1 / 2$ inch in diameter under a gradient of 50 feet to the mile (about the slope of the water table in the Brule at many places in Scotts Bluff County) is computed to be about 530 gallons a day. If it is assumed that the material comprising the Brule formation has no permeability whatsoever, but that a block of the formation 1 mile long, 1 mile wide, and 1 foot thick, contains one fissure equivalent hydrologically to a $1 / 2$-inch pipe, the block of the formation as a whole will transmit the same amount of water through it as an equivalent block of isotropic material whose average coefficient of permeability is about $\mathbf{1 0 . 5}$. Ten such openings in the block will, of course, inerease the average coefficient to 105, and 50 openings will increase it to 525 .

It is possible to make rough computations of the field permeability of the Brule formation as a whole by two general methods, namely, from losses of water stored in Lake Minatare and Lake Alice, and from the quantities of effluent seepage observed during the winter months in drains and short tributaries to the North Platte River.

Records furnished by T. W. Parry, manager; Pathfinder Irrigation District, show that the storage of water in Lake Minatare decreased from 28,101 acre-feet on October 31, 1937, to 25,736 acre-feet on March 31,1938 . During this period there was no surface inflow or outflow. If it is assumed that the loss of water by evaporation was approximately balanced by accretions from precipitation, then the observed loss in

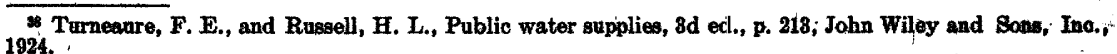


storage, 2,365 acre-feet, may be attributed chiefly to seepage into the Brule formation, The records indicate that the average stage of the water surface in the lake during the period under consideration was about $4,106.6$ feet, and that the area submerged at this stage was about 1,480 acres. The lake at low stages, such as occur during the winter months, may be considered essentially circular in shape, and for an area of 1,480 acres it thus has a circumference of about 5.37 miles. The contours on plate 3 show that during the winter months water probably percolates into the lake through about a quarter of the cylindrical cross-sectional area of Brule formation defined in plan by the circumference of the lake, and percolates out of the lake through about half the cylindrical cross-sectional area. There probably is very little underground movement of water into or out of the lake through the remaining quarter of the cylindrical cross-sectional area because the contours indicate that there is practically no hydraulic gradient across it. The conclusion may be reached that about half the percolation out of the lake is balanced by percolation into the lake and, therefore, that the water lost from storage in the period percolated out of the lake through an effective área equal to about a quarter of the cylindrical cross-sectional area of Brule.

The quantity of ground-water percolation may be computed by the formula, $Q=P_{f}^{\prime} I A$, where $Q$ is the quantity of percolation in gallons per day, $P_{f}$ is the field coefficient of permeability as defined on page $78, I$ is the hydraulic gradient in feet per mile, and $A$ is the cross-sectional area of the water-bearing material in feet thickness of mile width. The 2,365 acre-foot loss in storage occurred in $\mathbf{1 5 1}$ days. Thus there was an average daily loss of about 15.7 acre-feet, or about $5,100,000$ gallons. The hydraulic gradient, as indicated by the contours on plate 3 , is about 50 feet to the mile, and if the thickness of the Brule in which water-filled crevices occur is assumed to be 100 feet, the cross-sectional area, $A$, is equal to $100 \times 5.37 / 4$, or 134.25 . Substituting in the equation,

$$
\begin{aligned}
& 5,100,000=P_{f} \times 50 \times 134.25 \\
& P_{f}=760
\end{aligned}
$$

The field coefficient of permeability 'of the Brule is computed by this method to be 760 .

A similar computation for permeability can be made from the loss of water in Lake Alice. Records show that there was no surface inflow or outflow from the lake from November 30,1937 , to March 31, 1938. The loss in storage during this period was 464 ,acre-feet, an average of about 1,250,000 gallons per day. The stage of the water surface during the period averaged 4,160.7 feet and the area submerged averaged about 142 acres, or about 0.22 square mile. By following the methods used for computing the permeability from the storage loss in Lake Minatare, the cross-sectional area, $A$, is computed to be $100 \times 1.67 / 4$; or 41.75 . By substituting in the flow equation,

$$
\begin{aligned}
& 1,250,000=P_{f} \times 50 \times 41.75 \\
& P_{f}=599
\end{aligned}
$$

The second method of computing the field permeability of the Brule formation relates to the flow of the short tributaries to the North Platte River. During the winter these streams are fed almost entirely by groundwater seepage and hence the equation of ground-water flow may be applied to the percolation of water into them. The flow ${ }^{39}$ of Ninemile

a Nebraska Dept. Roads and Irrig., 22d Bienn. Rept., p. 802, 1937-38. 
drain, measured in sec. 25, T. 21 N., R. 53 W., during January; February, and March 1938, averaged about $56,000,000$ gallons of water a day. The records of daily discharge, indicate that there probably was very little surface runoff into the drain during these months. The hydraulic gradients toward the drain, taking into consideration the gradients from both sides for a length of 9 miles of drain, average about 35 feet to the mile. If the thickness of the Brule in which water-filled crevices occur is again assumed to be 100 feet, the equation of flow may be written

$$
\frac{56,000,000}{2}=P_{f} \times 35 \times 100 \times 9
$$

The value for the discharge of the drain is divided by 2 because the percolation is toward the drain from both sides.

Computations by this method were made from the flow of other tributaries to the North Platte River in Scotts Bluff County. They give the following values for field coefficients of permeability: 686 for Winter Creek, 243 for Spottedtail Creek (locally called Wet Spottedtail), and 263 for Gering drain.

The six values of field coefficient of permeability of the Brule computed by the two methods' range from a minimum of 243 to a maximum of $\mathbf{8 8 9}$ and average 573. A coefficient of 573 means that the formation will transmit 573 gallons of water a day through each strip of the formation 1 mile wide and 1 foot thick for each foot per mile of hydraulic gradient.

The Brule is eroded very easily, and hence in the irrigated parts of the county the openings have probably been enlarged by the circulation of water through them. Thus the permeability of the formation is probably greater in those areas than it is where the only source of the ground water is precipitation.

The moisture equivalent of two samples of Brule sent to the laboratory was determined. The samples were saturated with water, subjected to a centrifugal force approximately 1,000 times the force of gravity, and weighed. Then they were dried in an oven and reweighed. The loss of weight through drying represents the weight of the moisture that had remained in the samples after centrifuging. The moisture equivalent by weight is computed by dividing the weight of the moisture retained after centrifuging by the weight of the dry soil, and the moisture equivalent by volume is computed by multiplying the moisture equivalent by weight by the specific gravity of the material.

The moisture-equivalent determinations are made in order to ascertain the specific retention ${ }^{40}$, that is, the quantity of water that a soil or rock will retain against the pull of gravity. if it is drained after being saturated, expressed as the ratio of the retained water to the total volume of material. The specific yield of a material is equal to the porosity minus the specific retention. It has sometimes been assumed that the moisture equivalent and the speeific retention of a water-bearing material are approximately equal. However, several investigators have found that this relation holds more nearly when the moisture equivalent is comparatively large. Piper ${ }^{41}$ prepared a graph showing the relation between

\footnotetext{
40 Meinzer, O. E., The occurrence of ground water in the United States, with a disoussion of principlea: U. S. Geol. Survey Water-Supply Paper 489, pp. 55 et seq., 1923.

4. Piper, A.M.; Notes on the relation between moisture equivalent and the specifie retention of water-bearing materials: Am. Geophys. Union Trans. 14th Apn. Meeting, pp. 481-487, 1933.
} 
these properties, using the results obtained by him in the Mokelumre area, Calif., and the results obtained elsewhere by others. Where the moisture equivalent ranged between 3 and 5 percent, the specific retention was found to range between 5 and 7 percent. Moisture equivalents greater than 15 percent agreed more closely with the specific retention.

The moisture equivalents determined in the laporatory for the two samples taken from the Brule formation were 24.9 and 20.9 , respectively, an average of 22.9. Because the values fall in the higher range referred to by Piper, they can be taken to represent the approximate specific retention. The porosities of the samples were 51 and 54, an average of 52.5. Thus the average specific yield of the samples is 29.6. This indicates that a cubic foot of Brule, if allowed to drain for a long period', will yield about 0.296 cubic foot of water and will retain about 0.229 cubic foot.

Investigations have shown that a sample of material after being saturated will not yield its water at once but the water will drain rather slowly, the rate of draining being somewhat proportional to the permeability of the material. The Brule, because of its tight character, yields water sluggishly, and several months to a year or more are doubtless required before the specific yield calculated in the laboratory is reached. As a result the quantity of water that is removed from storage by a decline of the water table. in the Brule cannot be calculated from the specific yield determined in the laboratory unless the water table remains below the material for a long period. The comparatively large seasonal fluctuation of water levels in wells that tap the Brule results in part from the incomplete draining of the material during the time allowed. This means that the water table may decline for a considerable period before much water comes out of storage, except what drains from the,cracks and fissures. This decline, however, will gradually slow up as the water table reaches lower stages, and a greater thickness of the formation thereby becomes available for draining.

\section{DEPTH TO GROUND WATER}

Where the ground water is not confined, there is a water table. Where the ground water occurs in a confined formation, under artesian pressure the water will rise in wells to a level known as the piezometric surface. Both water-table and artesian conditions exist in Scotts Bluff County; hence at some places there may be two or more depths to ground water: namely, the depth to the water table and the depth to one or more formations containing water under artesian pressure.

The depth to the wáter table in Scotts Bluff County differs considerably from place to place, but in general it increases with distance from the North Platte River. Along the river bottoms the water table is less than 25 feet below the land surface in most places, but beneath the bluffs and along the valley limits it is as much as 275 feet. The depth to the water table, however, does not increase uniformly from the river to the valley'limits. There are areas near the river where the water table is comparatively deep, and there are areas near the edges of the valley where it is, near the surface. This is illustrated by the variation along the first north-south section line west of Gering where the depth to the water table is as follows: About 40 feet below the surface 0.5 mile directly 
south of the river; about 10 feet, 2.5 miles south; about 70 feet, 6 miles south; about 15 feet, 7 miles south; about 20 feet, 9 miles south; about 15 feet, 10 miles south; and about 25 feet below the surface 11 miles south. The variation in depth to the water table is shown also by the profiles in plates 4 and 5.

The water table lacks much of the irregularity that is common to the land surface. In Scotts Bluff County it is much smoother on the whole than is the land surface, but it is somewhat more irregular in detail than it is in many other sections of western Nebraska. In Keith County ${ }^{42}$ and in Box Butte County ${ }^{48}$ the water table is very smooth in comparison to the land surface and irregularities in the topography of the land surface are in most places not reflected by corresponding irregularities in the water table.

In Scotts Bluff County, the water table conforms to the land surface to a much greater degree than it does in Keith and Box Butte Counties. Beneath the comparatively steep slopes of ridges and knolls the water table is also steep; beneath the more gentle slopes of the terraces the slope of the water table is likewise gentle. As a result the depth to the water table beneath much of the higher land of the county is much less than it is in areas of comparable elevation in some of the other counties in western Nebraska. At the Sioux County line north of Scotts Bluff, the depth to the water table is only about 25 feet although in this locality the land surface is more than 300 feet above river level at Scotts Bluff. Three miles north of the Banner County, line in southwestern Scotts Bluff County the altitude of the land surface on the divide between the North Platte and Pumpkin Creek Valleys is about 500 feet above the river level at a point directly north, yet the depth to the water table is only about 15 feet. There are many other similar areas in the county.

The water table is comparatively deep, however, beneath some of the high land in the county. The water level in well 6 , about $1 / 4$ mile west of the Morrill County line and about 10 miles directly north of the North' Platte river, stood about 120 feet below the land surface on July 24, 1937. Depths to water level of more than 100 feet but less than 125 feet were measured also on the north side of the river in well 52, about 1 mile north of Lake Minatare; also in well 105 , about $31 / 2$ miles north of Lake Minatare; and in well 216, about 4 miles northeast of Mitchell. On the south side of the river, depths to water level of more than 100 feet were measured in well 11; about 3 miles southwest of McGrew; in well 87, about $51 / 2$ miles southeast of Gering; in well 103, about 4 miles west of Gering; in wells, 179,181, 182, 246, and 247 , on Wildcat Ridge just south of Roubadeau pass; and in well 312 , about 9 miles south of Lyman. The depths to water level in the wells south of Roubadeau pass were the greatest measured in the county. The water levels in wells 179, 181; and 182 stood at depths from about 138 feet to 165 feet below the surface. In wells 246 and 247 , the water level at the.portals was $\mathbf{2 7 2 . 7 5}$ feet and 217.85 feet, respectively, below the land surface.

During the course of the present investigation, measurements were made of the water levels in about 340 wells. (See table of well records, pp. 136-148.) It is estimated that the wells in which the water level was measured represent about 20 percent of all the wells of the county. The

\footnotetext{
Wensel, L. K., and Waite, H. A., Ground water in Keith Connizy, Nebr.: U. 8. Gebl. Survey WaterSupply Paper 848, Pp, 1-68, 1941.

"Cady, R. C.4 and Bcherex, O. J., Geology and ground water rescarces of Bor Butte Conuty, Nebr: U. \$. Geol. Survey Water-Supply Paper 968 (in preas).
} 
water levels in 161 wells, or almost one-half the wells measured, were less than 25 feet below the surface. In 98 wells the water level was between 25 and 50 feet below the surface; in 45 wells, between 50 and 75 feet; in 18 wells, between 75 and 100 feet; and in 13 wells the water level was more than 100 feet below the surface. The wells on which measurements were made are somewhat uniformly distributed over the county (see pl. 3) and the data obtained on them probably are txpical and representative of conditions in the area.

The comparatively shallow depths at which the water table stands in parts of Scotts Bluff County is believed to be caused to a large extent by recharge from irrigation. A large quantity of water reaches the zone of saturation each year by seepage from the network of irrigation canals, laterals, and ditches and from irrigated fields. This seepage undoubtedly maintains the water table at stages much higher than those that existed prior to the introduction of irrigation water. Although no early records of ground-water level are available, it is deduced from the fluctuations of water level in wells measured periodically during this investigation that in places the water table now probably stands from 10 feet to perhaps 50 or 100 feet above its stage before irrigation was begun. Observations made about weekly from July 1937 to August 1938 on well 89, in sec. 1, T. 22 N., R. 54 W., about $61 / 2$ miles north of Minatare, show that the water level rose from the middle of July to September 21, 1937, reaching a high seasonal stage of 30.95 feet below. the measuring point on the latter date. The water level then declined more'or less uniformly to May 17, 1938, at which time the lowest stage for the period was recorded -53.29 feet below the measuring point. A rapid rise in water level then occurred and on August 23, 1938, when the weekly measurements were discontinued, the water level stood 30.07 feet below the measuring point, the highest stage observed during the period. Inasmuch as the highest seasonal stages occured about at the end of the irrigation season and the lowest seasonal stage at about the beginning, most of the rise of about 23 feet may be attributed to recharge from irrigation and most of the decline, which was about the same as the rise, to discharge from the zone of saturation into streams and seeps. The decline of the water level in the well from September 21, 1937, to May 17, 1938, averaged about 2.8 feet a month, and during the last 2 months, from March 17 to May 17, it averaged about 1.6 feet a month. Thus it can be seen that the decline was still proceeding at a relatively high rate just before the ensuing irrigation season and that if there were no further recharge from irrigation, the water level in the well would reach a stage far below its lowest stage of 1938. The same general type of water-level fluctuation was observed in many other wells in the county. (See pls. 6 to 10.) That the water table at many places in the county is now considerably higher than in the past is indicated also by the construction of drainage ditches and by the large increase in surface inflow to the North Platte River and its tributaries that has taken place.

The depth to the water table is usually the least in summer, when recharge from irrigation is high, and greatest in winter and early in spring, when such recharge is low. The observations made in connection with this investigation were taken chiefly during summer and fall, and thus most of the water levels given in the table of well records (pp. 136-148) probably represent levels that are higher than the average levels for the year and considerably higher than the lowest levels for the year. 
Only rather meager information is available on the depth to artesian water, because of the comparatively few wells that are known definitely to tap it. South of Mitchell the 3 flowing seepage wells that penetrate the Brule formation were drilled to a depth of 110 feet below the surface. The artesian wells south of Lyman, which tap water in the Lance formation, range-in depth from 71 to 265 feet. Of 24 flowing wells in the Lyman area on which data regarding depth were obtained, 7 are less than 100 feet deep, 14 are between 100 feet and 200 feet deep, and 3 are between 200 and 265 feet deep. The average depth of the wells is about 133 feet. Wells near Scottsbluff and Gering, which struck artesian water in what is considered to be the Lance formation, were drilled to depths ranging from about 300 feet to 560 feet, but the water was encountered at somewhat shallower depths. The log of well F-2 at Gering (p. 57) indicates that a flow was encountered at about 315 feet below the surface but that the drilling was continued to a depth of 560 feet. . Similarly, the log of test well F-3, for City of Scottsbluff (p. 58) indicates that artesian water was struck between 244 feet and 250 feet, and again at 280 feet, but that the well was drilled to 303 feet. It is likely that the depths to the top of the strata bearing artesian water in the county are less than is indicated by the depths of the wells. The Lance formation is believed to dip eastward across Scotts Bluff County at a rate greater than that of the land surface. Thus artesian water in this formation is in general encountered at increasing depths from west to east.

\section{FLUCTUATIONS OF WATER LEVEL IN WELLS}

\section{METHOD OF INVESTIGATION}

In order to note the fluctuations of ground-water levels in the area about 45 . wells (see pl. 3) were selected for regular observation, and measurements of the depth to water level in them were made about weekly from July 1937 to August 1938. Three of the wells were equipped with automatic water-stage recorders, and continuous records of the fluctuations of water level in them were obtained for much of the period of investigation. The measuring of the water levels in 9 of the wells was begun prior to the investigation of Scotts Bluff County as a part of the State-wide program of ground-water level observations ${ }^{44}$, and the records for these wells therefore, extend over a longer period than do those for the other wells. A few measurements of 'water level have been made in some of the observation wells since the field work for the Scotts Bluff investigation was completed, and these measurements, together with those made previously, have been published in annual volumes ${ }^{46}$ of the Geological Survey on water levels and artesian pressure in the United States. It is expected that any measurements of the water levels in the wells that may be made in the future will be published in succeeding volumes of this series. Observation well numbers used in this report and corresponding numbers used in the State-wide observation program (publication numbers in the annual volumes of water levels and artesian pressure) are given in the accompanying table.

\footnotetext{
W Wensel, L. K., A State-wide program of periodic measurements of ground-water level in Nebrutra: Am. Geophys. Union Trans, 16th Ann. Meeting, pp. 495-498, 1935. Waite, H. A., Ground-water level earvey in Nebraska: Nebraska Geol. Survey Paper 7, pp. 1-14, 1935.

4s See U. : S. Geol. Sarvey Water-Supply Papers 817, 840, 845, and 886.
} 
Observation well numbers used in this report, and corresponding numbers used. in State-wide program

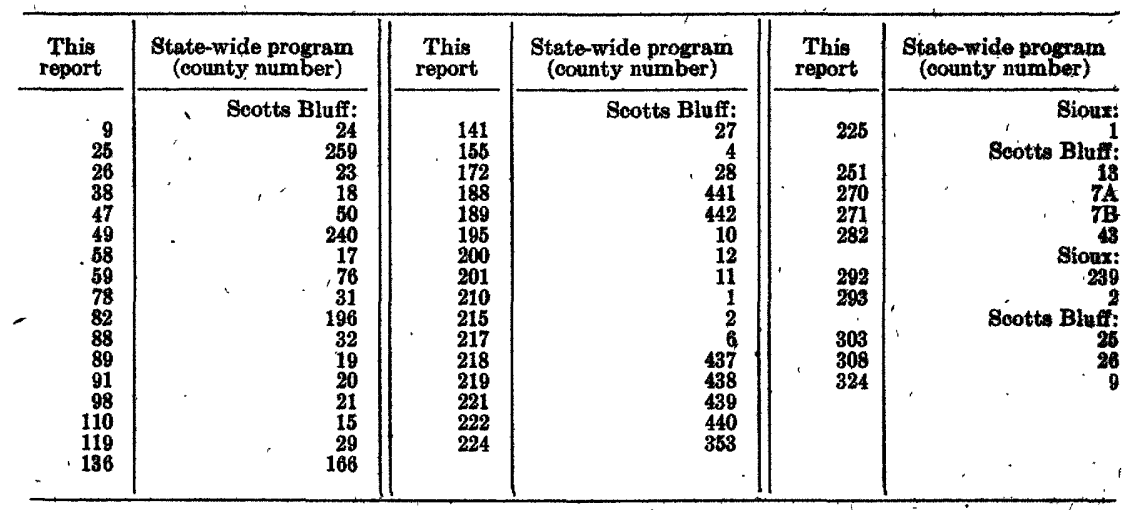

The depth to the water level in the observation wells was measured with a steel tape to the nearest hundredth of a foot. The tape was coated with blue or white carpenter's chalk before it was lowered into the water, in order that a definite mark could be obtained, and lead weight was attached to prevent it from becoming slack. All measurements were made from definitely established measuring points. On most wells the top of the pipe or casing was used, but on some a permanent point on the pump base or wood curb was selected. Each measuring point was plainly marked with keel, and the number of each well was posted in a conspicuous place nearby. A description of the measuring point, its distance above or below the general land surface, and other information on the well were recorded. These data are given in the table of well records at the end of this report.

In Geological Survey Water-Supply Papers 817, 840, 845, and 886, the water-level measurements made in each well in connection with the Statewide program have been expressed in feet above an assumed datum, which is 100 feet below the water level in that well on January 1,1935 . The height of the measuring point above the datum for wells established after January 1, 1935, has been interpolated from the average water level in a group of similar wells on a selected date. The water-level measurements made in observation wells in Scotts Bluff County are also expressed. in feet above assumed datum planes in the annual volumes of water levels and artesian pressure of the Geological Survey, the datum planes for most of the wells being selected 100.50 feet below the water level on the last day of measurement in 1937. This figure was obtained by averaging the height of the water levels on the last day of measurement in 1937 in 3 wells (Nos. 49,-224, and 292 in this report), included in the State-wide program, for which datum planes had been established prior to the investigation of Scotts Bluff County described herein.

The measurements were plotted as hydrographs showing the fluctuation of the water levels in the wells, and most of the hydrographs are here reproduced. (See pls. 6-9.) Hydrographs of the 9 wells on which observations were started prior to 1937 are shown on plate 10. All the water levels are plotted in feet above the assumed datum planes. 


\section{GENERAL CONDITIONS}

Both the water table and the piezometric surfaces of the ground-water reservoirs in Scotts Bluff County fluctuate almost continuously, as is shown by the water levels in wells. The stage of the water table reflects the quantity of water in storage in the ground-water reservoirs, much as the stage of the water level of a surface reservoir reflects the quantity in storage there. Changes in the water levels in the wells thus indicate changes in storage in the ground-water reservoir and give clues as to the magnitude of the recharge and discharge. The fluctuationg of water level show to what extent the ground-water reservoir is depleted by heavy withdrawals resulting from pumping for municipal waterworks, irrigation, or industrial uses, by natural drainage, and by losses due to transpiration and evaporation; they also show to what extent it is replenished by such agencies as rainfall, seepage from streams, and the spreading of irrigation water. Continuing observations on the water levels in wells are therefore important in helping to estimate the quantity of water that may be withdrawn annually from the ground-water reservoir without permanently depleting the supply. Observations extended over many years may show also whether a progressive decline or rise of the ground-water level is in progress.

The principal factor controlling the rise of the ground-water level in Scotts Bluff County is the amount of seepage from irrigation canals and irrigated fields. There are rises caused by the penetration of rainfall to the zone of saturation, seepage from the North Platte River, and by underflow, but the records of water level obtained from the observation wells indicate that the effects of these recharge factors are obscured to a large extent by the larger fluctuations caused by seepage of irrigation water. The principal factors controlling the decline of the ground-water level are percolation to streams and drainage ditches of the area and the withdrawal of water from the zone of saturation by transpiration of plants and evaporation from the soil in localities where the water table is near the surface. The decline of the water level is caused to a lesser extent by the pumping of water from wells.

The largest fluctuations were observed in wells situated in the part of the valley irrigated with surface water, notably in wells in the northeastern part of the county. During the 14-month period of observation, from July 1937 to August 1938, the difference between highest and lowest water levels amounted to about $131 / 2$ feet in well $38,61 / 2$ miles north of Minatare; about 23 feet in well 89 , about 5 miles west of well 38 ; nearly 21 feet in well 59, near the west edge of Lake Minatare; and about 16 feet in well $110,11 / 2$ miles northwest of Lake Minatare. Fluctuations of comparable magnitude were observed only in wells in Cedar Valley, where the water level in well 119, 6 miles south of Gering, fluctuated through a range of about 15 feet, and the water level in well 78, 4 miles south of Gering, fluctuated through a range of nearly 10 feet. Fluctuations of 5 to 10 feet were observed in many of the wells in the irrigated parts of the county.

The smallest fluctuations of water level were observed in wells in areas not affected by irrigation with surface water and in wells close to the North Platte River, where the water occurs in Pleistocene and Recent sand and gravel, and the water table is near the surface. Fluctuations of 
less than 2 feet occurred in well 26, about 0.5 mile north of the North Platte river near McGrew; in well 141, about 0.5 mile north of the river and 1 mile west of Scotts Bluff; in well 221, in Mitchell and about 0.5 mile north of the river; in well 222, near the river's edge south of Mitchell; in well 224, about 0.25 mile south of the river and about 1 mile south of Mitchell; in wells 303 and 308 , in the southwestern part of the county above the irrigation canals; and in well 324 , near the north bank of the North Platte River at Henry.

The water levels in wells affected by irrigation with surface water generally reach their lowest stages of the year in April or May, just before diversions are begun from North Platte River. In these wells the highest stages reached each year are generally recorded in September or October, near the end of the irrigation season. The water levels in wells unaffected by irrigation usually reach their highest levels in May or June and their lowest levels in October or November. Thus the fluctuations of water level in wells of the county may be quite dissimilar; in fact, the water levels in some may have opposite trends for much of the year.

\section{FLUOTUATIONS OAUSED BY SEEPAGE FROM IRRIGATION DITOHES AND IRRIGATED FIHLDS}

Water is usually turned into the network of canals and laterals in Scotts Bluff County in April or May and some flow is generally maintained in them until about October. During this period, which is known as the irrigation season, water is diverted from the canals at numerous places and is led to fields and applied to crops. In the intervening months, the nonirrigation season, the canals are dry except for the rain and snow water that may collect in them, and during this period, of course, no irrigation water is applied to the fields. The canals are not lined and opportunity is afforded throughout their length for an almost continuous loss by seepage during the times when a flow is maintained in them. Because most of the canals lie above the water table, practically no water seeps back into them and thus the seepage may be considered essentially a net loss with respect to the flow of the canals.

The effect of seepage from canals and irrigated fields on water levels in wells in the irrigated area is shown by the hydrographs on plates 6 to 10 . The hydrographs show a general seasonal fiuctuation, a rise from April or May to about September and a decline during the intervening months. The hydrographs differ considerably in detail, however, and show that the maximum and minimum seasonal stages are reached at different times in different wells, that the rates of rise and decline also differ, and that the magnitude of the seasonal fluctuations range appreciably in different wells. The differences in detail are caused in part by the different distances of the wells from canals and irrigated fields, but probably mostly by variations in the flow of the canals which in turn cause variations in the effective head that produce the seepage, by differences in the size of the canals and differences in the quantity of water carried by them, by differences in the dates on which water is first diverted to the canals at the beginning of the irrigation season and the difference in length of time that a flow is maintained, and by differences in the permeability and specific yield of the water-bearing formations.

In western Nebraska the water levels in wells not affected by such artificial recharge as seepage from canals generally decline during the 
growing season and remain more or less stationary or rise in the winter months. Recharge from precipitation in some years causes rather sharp rises in water level in wells in such areas in spring or early in summer. This type of fluctuation is illustrated by the hydrograph of well 303 (pl. 9), situated on the divide between the North Platte and Pumpkin Creek valleys in the SW1/4 SW $1 / 4$, sec. 12 , T. 20 N., R. 58 W., far above the highest irrigation canal in the county.

The fluctuations of water level in wells affected by artificial seepage contrast strikingly with the more usual type of fluctuation just described. The water levels generally rise in the summer months and decline in the winter months. Thus the trend of the water levels in areas irrigated by surface water is opposite throughout most of the year to that in wells in unirrigated areas. The upward trends of the water levels in summer and the downward trends in winter are shown by the hydrographs of most of the wells in Scotts Bluff County, but are indicated most clearly by the hydrographs of wells $38,58,78,83,89,110,119,200,201,210$, and 225.

The rate of decline of the water levels in the wells during the winter reflects to some extent the height to which the ground-water level has been raised by seepage since irrigation was first practiced. It may be assumed that the ground-water level is now much higher than it was originally in areas where the rate of decline during the winter is com-. paratively great. Conversely, where the rate of decline is small it is likely that the ground-water level has not been built up so much as it has been in the other areas. This line of reasoning cannot be followed mechanically, however, because the rates of decline of the water levels in some wells may be small because of underground percolation of water from areas situated up the hydraulic gradient. Thus the ground-water discharge of one area may be replaced in part by the discharge from another area and this transfer of storage will be reflected by the difference in the seasonal fluctuations of the ground-water levels in the two areas. . If no water was maintained in the canals for several years there would be a gradual equalization of water levels over the area, and during this period the water levels in some areas, which now show only small seasonal fluctuation, would doubtless decline considerably.

The hydrographs indicate in a general way that the ground-water level in northeastern Scotts Bluff County, especially in the vicinity of Lake Minatare, probably has been built up as much or more by seepage from the lake and from the canals that traverse the area than it has in most other parts of the county. A considerable rise of ground-water level probably also has taken place in Cedar Valley, on the south side of the North Platte River south of Mitchell and in the area along the Scotts Bluff-Sioux County line north of Morrill and Mitchell. Less evidence of the building up of the ground-water level is shown by the hydrographs of wells within a few miles of the river, but this may be expected inasmuch as these areas probably receive the most recharge by ground-water percolation from the higher lands of the valley.

The effect of seepage from canals on fluctuations of ground-water level is illustrated in plate 11. Well 282 is in the NW1/4 SW1/4 sec. 22, T. 23 N., R. $57 \mathrm{~W}$., about 1 mile south of Mitchell and 0.2 mile south of the canal. The discharge of Ramshorn canal (water diverted from the North Platte River) is measured about 3 miles west of well 282 in sec. 18, T. 23 N., R. $57 \mathrm{~W}$. The graph shows that the water level in well 282 declined more or less persistently from July 1937 to May 1938 and then 
rose to August 1938. A flow was maintained in the canal throughout July, August, and September 1937 and from the last part of May to August 1938. The gradual but irregular decline in flow of the canal during the summer months of 1937 is accompanied by-a similar trend of the water level in the well and the increase in flow of the canal during the spring and summer of 1938 is accompanied by a rise of the water level in the well. Some of the irregular fluctuations of water level are caused by pumping water from the well for irrigation. The graphs show that the water level in well 282 began to rise in spring about as soon as water was diverted from the river into the canal and that the recharge was sufficient in only about $21 / 2$ months to offset the decline that occurred during the preceding $91 / 2$ months.

A somewhat similar correlation between the discharge of canals and the water levels in wells for the irrigated area in Scotts Bluff County as a whole is shown on plate 11 . Here the weekly average of the water levels in 20 wells (Nos. $38,58,78,88,89,91,98,110,119,155,195,200,201$, $210,215,217,218,251,271$, and 282) and the aggregate monthly discharge of 9 irrigation canals (Gering, Tri-State, Ramshorn, Enterprise, Winter Creek, Central, Minatare, Ninemile, and Castle Rock) are plotted for the period July 1937 to August 1938. The weekly average , water levels used in constructing the graph shown on plate 11 are given in the accompanying table. The graph shows that the highest average water level in 1937 was reached on September 27, after a rise from August 2. There followed a $61 / 2$-month regular decline to about the middle of April 1938, at which time a rise started that continued through to the end of the record on August 22.

Average of the water levels in 20 wells in Scotts Bluff County affected by seepage from irrigation water

\begin{tabular}{|c|c|c|c|c|c|}
\hline Date & $\begin{array}{c}\text { Average water level, } \\
\text { in feet below measur- } \\
\text { ing points }\end{array}$ & Date & $\begin{array}{c}\text { Average water level, } \\
\text { in feet below measur- } \\
\text { ing points }\end{array}$ & Date & $\begin{array}{l}\text { Average water level, } \\
\text { in feet below measur- } \\
\text { ing points }\end{array}$ \\
\hline 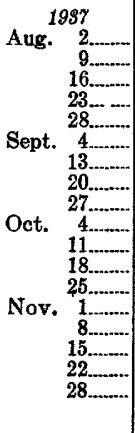 & $\begin{array}{l}28.36 \\
28.17 \\
28.09 \\
27.96 \\
27.90 \\
27.61 \\
27.49 \\
27.26 \\
27.15 \\
27.26 \\
27.56 \\
27.88 \\
28.22 \\
28.57 \\
28.76 \\
29.00 \\
29.34 \\
29.52\end{array}$ & 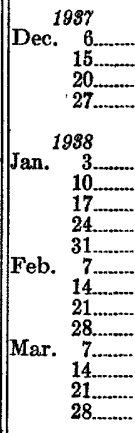 & $\begin{array}{l}29.66 \\
29.92 \\
30.11 \\
30.37 \\
\\
30.55 \\
30.68 \\
30.88 \\
31.06 \\
31.19 \\
31.36 \\
31.58 \\
31.67 \\
31.82 \\
31.96 \\
32.02 \\
32.15 \\
32.18\end{array}$ & 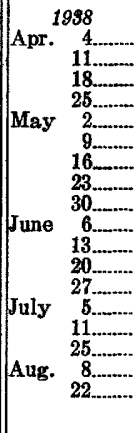 & $\begin{array}{l}32.41 \\
82.53 \\
32.57 \\
32.52 \\
32.39 \\
32.46 \\
32.29 \\
31.69 \\
31.48 \\
31.28 \\
30.95 \\
30.15 \\
29.75 \\
29.17 \\
28.54 \\
27.80 \\
26.98 \\
26.50\end{array}$ \\
\hline
\end{tabular}

The reversal of trend in April coincides with the first diversions of water into the canals, and the continuity of the upward trend from April to August correlates fairly well with the monthly trend of the discharge of the canals. The illustration shows, however, a negative correlation in September 1937 between the trend of the average water levels and the trend of the monthly discharge of the canals. The flow of the canals 
during September was only about two-thirds of that in August, whereas the average water levels were higher on all dates in September than they were on corresponding dates in August. This suggests that considerable time may be required before the effect of changes in the rate of seepage from canals may be transmitted over the whole of the irrigated area.

A close correlation should not necessarily be expected between the flow of the canals and the average of the water levels in the wells because an increase in flow of the canals does not necessarily indicate that there will be a proportional increase in seepage loss or a proportional rise of the water levels in wells. Moreover, a given quantity of seepage from the canals will cause a greater net rise of water level in wells in the spring months than it will in the fall months. In spring the ground-water levels are low and the discharge from the underground reservoirs also is low; in fall the ground-water levels are high and the discharge also is high. It is likely that the seepage from the canals in October 1937 was equal to or greater than that in the following. April, yet in October the water levels declined on the average about 1.3 feet, whereas in April the decline averaged only about 0.1 foot. This difference probably was caused more by differences in discharge from the underground reservoirs than by differences in the quantity of seepage from the canals.

The average of the water levels in the 20 wells rose about 6 feet in the 4-month period from April to August, most of this rise doubtless being caused by seepage from canals and irrigated fields. It is not to be inferred that this rise reflects closely the magnitude of the seepage loss from the canals. During the period of rising ground-water levels there is, of course, discharge from the underground reservoir and hence the rise indicates merely that the recharge exceeds the discharge. Inasmuch as the ground-water discharge from the area increases as the water levels rise, a given rise late in summer would indicate more recharge than an equal rise in the spring.

If the downward trend of the hydrograph during the winter months is projected on to August, the average of the water levels in the wells in August would be about 34.5 feet below the measuring points. This stage presumably would have been reached approximately had the winter discharge-recharge relation continued through to August: Instead, recharge so increased from April to August that the average of the water levels rose to a stage in August of 26.5 feet below the measuring points. Thus an estimated gross average rise in water level of about 8 feet is indicated.

The gross rise in average water level was computed on the basis that the discharge-recharge relation prevailing during winter continued into the summer months. Actually, the discharge from the underground reservoir increases considerably during summer, mostly due to the use of water by plants, and hence the rate of fall of the average water level in summer accelerates instead of remaining practically constant. If the October-April limb of the hydrograph is projected on to August with a gradually increasing slope, showing that the discharge from the underground reservoir gradually increased from April to August, the average of the water levels in August would be 36 to 37 feet below the measuring points. Thus it is probable that the seepage from the canals and fields during the period April to August caused the water levels to reach an average stage in August approximately $91 / 2$ to $101 / 2$ feet above the stage that would have occurred had there been no recharge of this kind. 


\section{FLUCTUATIONS CAUSED BY CHANGES OF WATER STORED IN TAKT MINATARE}

Lake Minatare is a nonchannel reservoir of the Pathfinder Irrigation Project in northeastern Scotts Bluff County. Water to fill Lake Minatare and Lake Alice, which is a similar but much smaller reservoir about 5 miles northwest of Lake Minatare, is diverted from the North Platte River at Whalen Dam, in Wyoming, and is conducted to the lakes in the Interstate canal. The arrangements are such that water in the canal may bypass both lakes and continue eastward in the high-line canal, or it may be carried into the lakes, which are connected by a canal, and be released from Lake Minatare as needed through the low-line canal.

Water is usually diverted into the lakes in spring and summer and is released from them during summer and early in fall. Records furnished by T. W. Parry, manager, Pathfinder Irrigation District, show that for the period July 1, 1937, to August 31, 1938, the lowest stage of Lake Minatare was reached on August 14, 1937, and the highest on June 5, 1938. The difference between the highest and lowest stages was 26.5 feet, and the area inundated at the maximum was approximately twice that submerged at the minimum stage.

The weekly water levels in well 59, near the western margin of Lake Minatare, and the daily stage of the water surface of Lake Minatare are plotted for the period July 1937 to August 1938 on plate 11. The distance from the well to the margin of the lake varies from a few hundred feet to about half a mile, depending on the size and hence the stage of the lake. The level of the water in the well varies through the year from about 10 to 20 feet lower than the level of the surface of the lake. The decline shown by the graphs in August 1937, the rise in October, the gentle decline from about October to April, the sharp rise in May, and the subsequent decline in July and August all show that there is a fairly close relation between the fluctuations of the lake surface and the fluctuations of the water level in the well.

The correlation between the stage of the lake and the water level in the well is closest when the lake is at high stages because the distance from the lake. to the well is then short and the area through which percolation may take place out of the lake is large. The lake level was comparatively low in the early part of August 1937, and the graphs show that the trend of the water level in the well and the trend of the water surface of the lake were both downward. The lake level reached its lowest stage on August 14 and then rose about 4 feet by August 23, but the effect of this rise on the water level in well 59 is shown only by a small rise from August 16 to August 23 and by the more or less horizontal trend of the water level through the rest of August and through September. The stage of the lake was comparatively high in June 1938 and the lake level declined about 2 feet and then rose about 1 foot. The effect of these changes in lake level are clearly reflected by corresponding changes of water level in the well.

The graphs on plate 11, show that the effect of changes of lake level are transmitted through the Brule formation to the well only after an appreciable delay. The fluctuations of water level in the well lag behind the fluctuations of lake level; hence during rising stages of the lake the water level in the well is relatively low and during declining stages of the lake it is relatively high. The lake, during the rising stage of April- 
June 1938, reached an elevation of 4,112 feet on May 5, at which time the water level in the well stood about 102.7 feet above the assumed datum, but when the lake, during the subsequent declining stage of June-August, reached the elevation of 4,112 feet on August 17, the water level in the well was about 108.3 feet above the assumed datum. The difference in lag between the rising and falling stage was thus 5.3 feet.

It is difficult to determine closely the time required for changes in water level of the lake to reach the vicinity of the well because only weekly measurements of the water level in the well are available. The fluctuations in June and July 1938 indicate, nevertheless, that the lag is several days. The lake level began to decline on June 7 but the rising trend of the water level in the well apparently was not reversed until after June 14, 7 days later. Similarly the declining trend of the lake level was reversed on June 24 but that of the water level in the well was not reversed until after June 27, 3 days later; the rising stage of the water level was reversed on July 2 , but the water level presumably did not begin to decline until after July 5,3 days later. Thus a 3-to 7-day lag is indicated.

The fluctuations during October, November, and December 1937 indicate that although the first effect of a change in lake level may be transmitted to the well in a few days, a considerably longer time may be required before full adjustment of the change takes place. The lake level rose about 7 feet from September 30 to October 15 and then declined very slowly until April 1938. The water level in the well presumably began to rise a few days after September 30 , and the rise continued at a decreasing rate until about the middle of December. About 2 months thus were required before the full effect of the October rise of lake level was transmitted to the well.

\section{FLUOTUATIONS CAUSED BY PREOIPITATION}

Under favorable conditions of soil moisture a part of the precipitation seeps down through the soil and is added to the zone of saturation. The average annual precipitation in Scotts Bluff County is about 15.5 inches, and the recharge to the zone of saturation from this source is small, especially in comparison to the amount of recharge received by seepage from irrigation water. The graphs showing the fluctuations of water level in the observation wells (pls. 6 to 10) indicate that the effects of recharge from precipitation are, for the most part, masked by the much larger fluctuations caused by seepage from canals and irrigated fields.

The monthly precipitation from 1935 through 1940 , measured by the station of the United States Weather Bureau near Mitchell, is plotted at the bottom of plate 10. A comparison of the plot of the precipitation with the hydrographs of the wells shows a general correlation, but inasmuch as some of the fluctuations shown by the hydrographs are caused by irrigation and others by changes in stage of the North Platte River, the correlation may be considered rather poor.

The plot of the precipitation on plate 10 shows that rainfall from July 1937 to August 1938, the period for which weekly measurements of water level in the observation wells are available, was greatest in the months of May, June, and July 1938 . The rain occurred chiefly as storms extending over several days near the ends of May and June and near the middle of July. The hydrographs of some of the wells show 
rises during these periods that may be the result of the rainfall from the storms. The hydrograph of well 9 (pl. 6) shows a rise of nearly 3 feet during the latter part of May and a rise of about 2 feet during the latter part of June, but it shows no effect of the rainfall in July. Similar rises, but of smaller magnitude, are shown by the hydrographs of wells 141 and 172 (pl. 8) and well 251 (pl. 9). It is doubtful whether the rises of water level in the wells resulted solely from rainfall penetration, because the flow of streams, canals, and ditches near the wells generally increases during periods of heavy rainfall, and these increases in flow also produce rises in ground-water level. The hydrograph of well 303 (pl. 9) shows a marked rise in early June that doubtless was caused by penetration of the May rains since this well is situated far above the highest irrigation canal. The hydrograph of well 308, however, shows practically no rise during this period. The water level in this well is believed to be unaffected by irrigation, and the absence of a rise in water level may be due to the fact that the water level in June 1938 was about 30 feet below the land surface whereas the water level in well 303 was only about 18 feet below the surface. The effect of recharge from precipitation is usually much more difficult to discern in areas where the water table is deep than in areas where it is shallow.46

The hydrograph of well 136 , reproduced from charts obtained with an automatic water-stage recorder, and the cumulative precipitation at Scottsbluff for the period May 15 to May 24, 1938, are shown in figure 8. A comparison of the graphs shows that there isagood correlation, although with about a day's lag, between the precipitation and the rise of water level in the well. The rainfall from May 16 to 19 totaled about 2.5. inches (about 0.21 foot) and the rise of water level in the well from May 17 to 20 was about 0.23 foot. Thus, the rise in water level exceeded the rainfall by about 0.02 foot. A rise of ground-water level does not give directly the increase in underground storage because only the open spaces in the ground are available for storing the water. Recharge from precipitation occurs only when conditions are especially favorable, and in Scotts Bluff County probably only a small percentage of the precipitation reaches the water table each year.

\section{FLUCTUATIONS CAUSED BY CHANGES IN FLOW OF THE NORTE PLATTE RIVER}

When the flow of the North Platte River increases, the water surface of the river rises above the water table at its banks. Consequently, water percolates out of the river into the ground until the adjacent water table is raised to a level approximately corresponding to the stage of the river. Conversely, when the flow of the river decreases, the water surface declines below the ground-water level, and water flows back into the river until the water table declines to a position corresponding approximately to the stage of the river. The contour map of the water table (pl. 3) indicates that these fluctuations of river stage may affect the water table in Scotts Bluff County for perhaps a mile from the river because the water table for about that distance, particularly north of the river, has about the same rate and direction of slope as the river. A small rise or fall in the stage of the river thus produces a change of

${ }^{46} \mathrm{Cady}$, R. C., Ground-water recharge in areas of deep water table in the great plains: Am. Geophys Union Trans. 21st Ann. Meeting, pp. 570-574, 1940. 

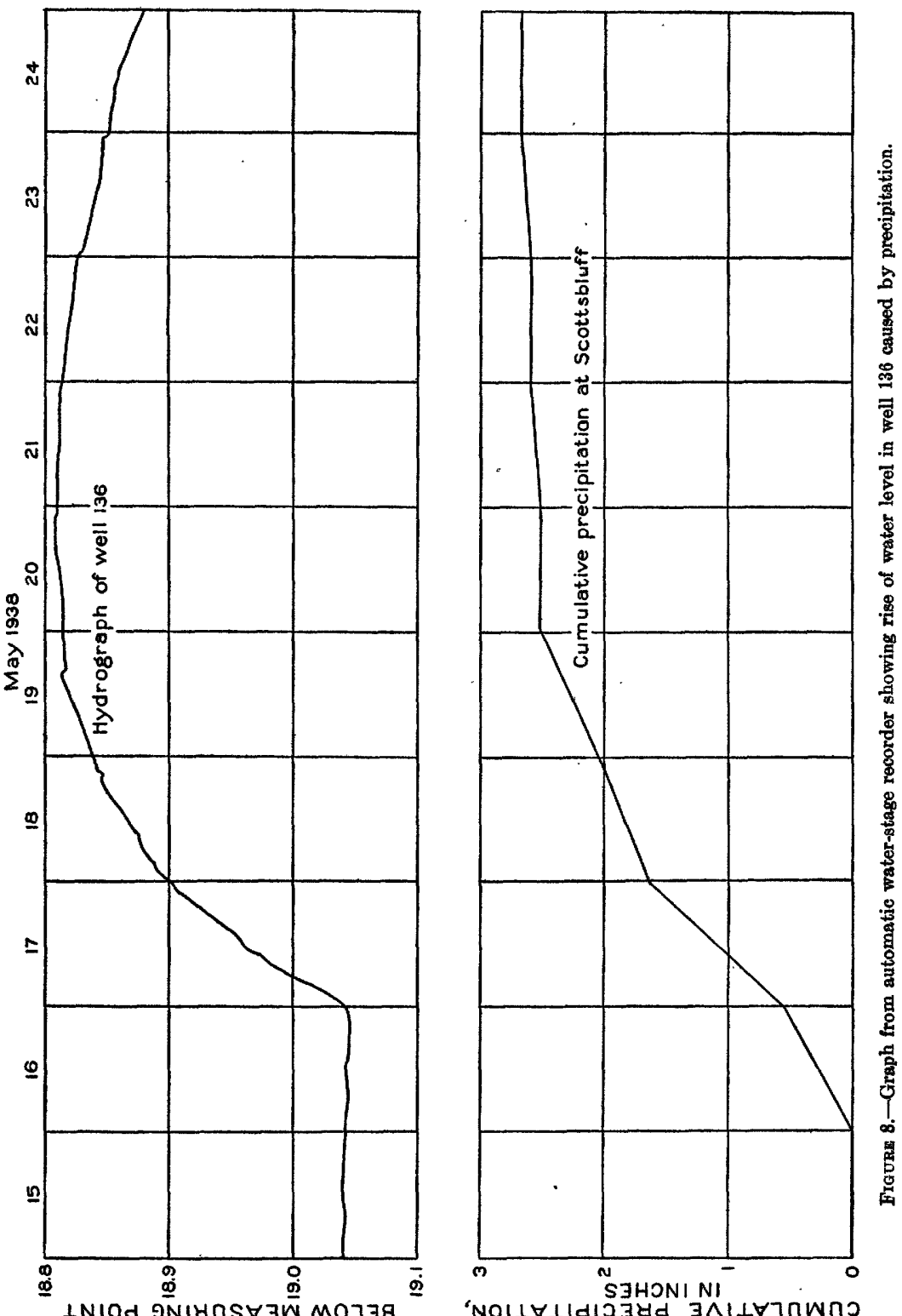

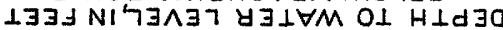


gradient for a mile or more from the river. As the stage of the North Platte fluctuates throughout the year it loses water at times to the zone of saturation and gains water at other times from the zone of saturation. There is a lag between the fluctuations of the river and the fluctuations of the adjacent water table, because water is transmitted slowly through the water-bearing bed. Thus the rise and fall of river stage is transmitted through the underground reservoir in waves, the amplitude and distance between crests and troughs depending respectively upon the magnitude of the change in stage and the length of time that the new stage is maintained. ${ }^{47}$ The longer the river maintains its new stage the farther back from the river will the water table be affected.

The weekly stage of the water level in well 222, situated near the north bank of the North Platte River south of Mitchell, and the discharge of the river at Mitchell on the same days, are plotted in figure 9. A com-
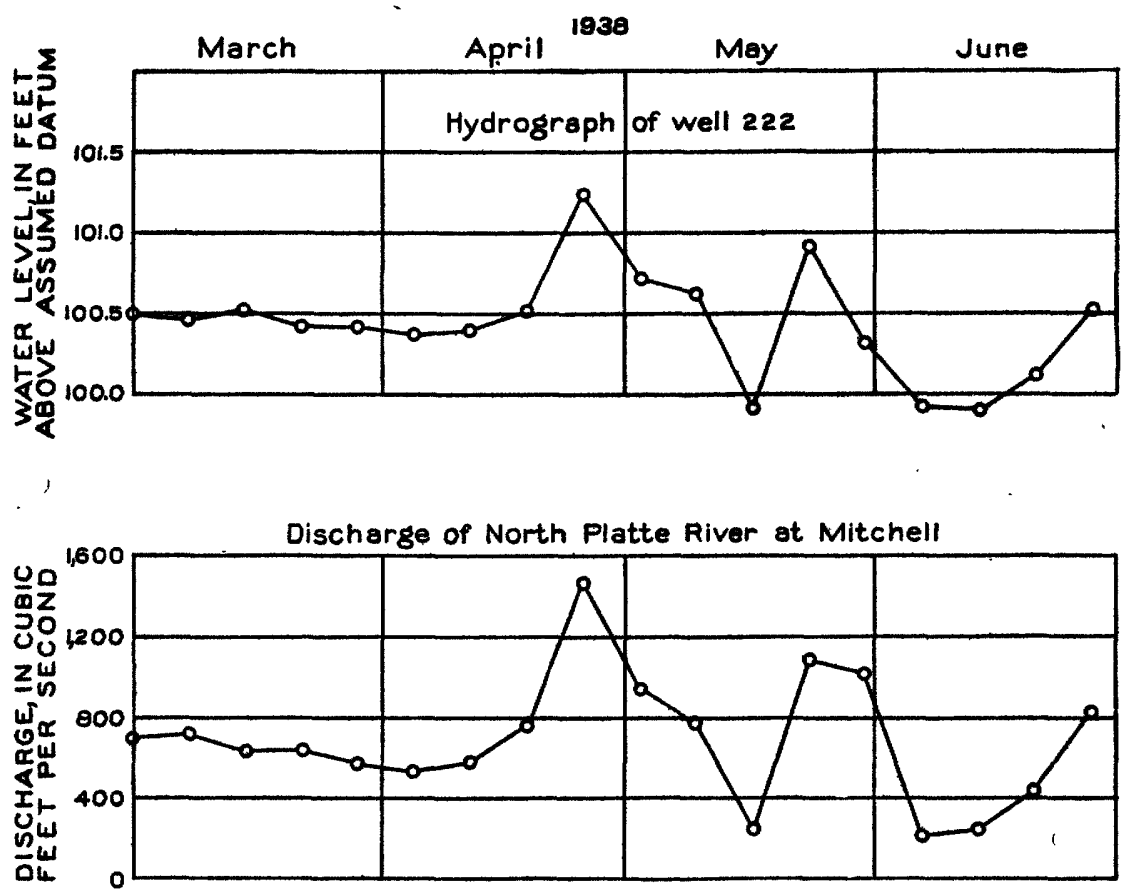

Fraunx 9.-Graphs showing relation between fluctuations in discharge of the North Platte River at Mitchell and fluctuations of water level in well 222 .

parison of the two graphs shows that there is a close correlation between changes of river stage and changes of water level in the well and also that the fluctuations of the water table in the vicinity of the well are probably controlled almost entirely by the flow of the river. Similar fluctuations of the water table doubtless occur along the North Platte River and its tributaries at other places in the county.

"For a description of the effect of changes in lake and river stages on ground-water levels, see Cady, R. C., Fffect upon ground-water levels of proposed surface-water storage in Flathead Lake, Mont., U. S. Geol. Survey Water-Supply Paper 849b, pp. 59-81, 1941. 


\section{PLUCTUATIONS CAUSED BY PUMPING OF WEIIS}

As soon as a pump begins discharging water from a well that penetrates a water-bearing formation with a water table, a hydraulic gradient from all directions is established toward the well and the water table is lowered around the well. Some water-bearing material will be unwatered by the decline of the water table, and the water drained from this material will percolate toward the pumped well. Thus for a short time after pumping begins most of the water that is pumped may be obtained from unwatered sediments comparatively close to the pumped well and temporarily very little water may be drawn to the well from greater distances. However, as pumping continues, a hydraulic gradient that is nearly an equilibrium gradient will be established close to the well, and there water will be transmitted through the water-bearing material at nearly the rate at which it is being pumped. This necessitates the percolation of more water from greater distances, and hence the cone of depression will expand, gradually draining material at greater distances. Thus as the pumping of the well continues, more of the formation will be unwatered and a draw-down of the water table will be noted farther from the pumped well. If no water is added to the formation, the water table will continue to decline as long as the well is pumped, and the cone of depression will eventually extend to the limits of the formation. Recharge to the formation, however, may retard the development of the cone of depression by furnishing additional water, which will become a supply for the pumped well.

After the discharge of a well is stopped, water momentarily continues to percolate toward the well under the hydraulic gradient set up during the period that the well was operating, but instead of being discharged it refills the well and the interstices of the material that were unwatered. As the formation near the well is gradually refilled, the hydraulic gradient toward the well is decreased and the recovery becomes progressively slower. At distances comparatively far from the well the water level may continue to lower for a considerable time after the discharge from the well ceases because at those distances water still is taken from the interstices of the material to supply the water that refills the sediments around the well. In time there is a general equalization of water levels over the entire region and the water table will assume a form similar to that which it had before pumping began, although it may remain temporarily or permanently somewhat lower than before water was withdrawn.

Fluctuations of water level in well 303 that resulted from the pumping of well 305 are shown in figure 10. The hydrograph was obtained by an automatic water-stage recorder. Well 303 is in the $\mathrm{SW} 1 / 4 \mathrm{SW} / 4$ sec. 12 , T. 20 N., R. 58 W., about 14 miles south of Lyman, and well 305 , in section 13 , is about 600 feet south of well 303 . Both wells tap water in the Brule formation. Well 305 was pumped at a rate of about 400 gallons a minute from about 1 p.m. to $6: 30$ p.m. on August 10, 1937, and from about 9 a.m. to 4:30 p.m. on August 13 .

The hydrograph illustrates clearly the general behavior of the water table in the vicinity of a pumped well, but it shows also that the fluctuations of water level did not occur precisely in a theoretical manner. Although the water level in well 303 began to decline very soon after the start of pumping of well 305, a lag of several hours occurred between 


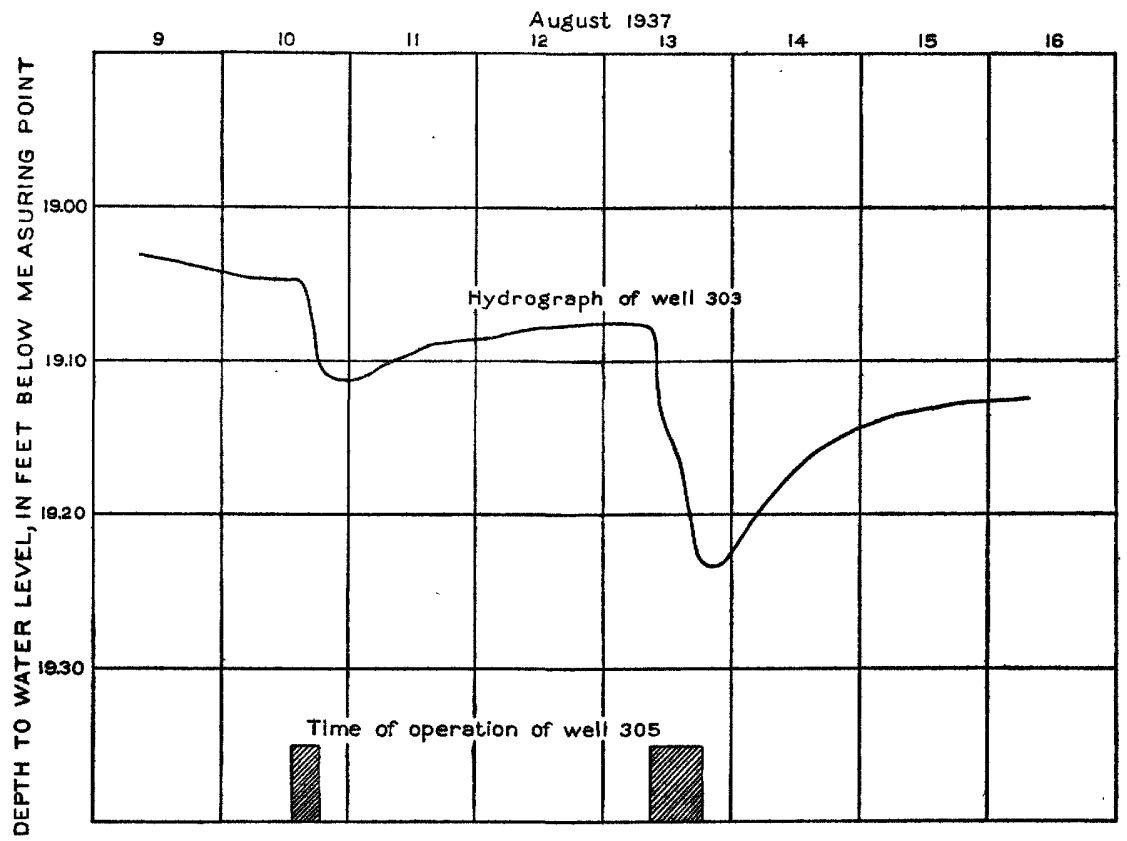

FIGURE 10.-Graph from automatic water-stage recorder showing fluctuations of water level in well 303 caused by pumping well 305 .

the cessation of pumping and the beginning of recovery in well 303 . Moreover, the slopes of the parts of the hydrograph that show the drawdown of the water level caused by the pumping are much steeper than are the parts of the hydrograph that show recovery due to the stopping of pumping. These facts suggest that the permeability of the Brule in the vicinity of wells 303 and 305 is appreciably higher than the permeability of the formation at greater distances from the wells. Thus most of the water withdrawn from well 305 was taken from storage in the Brule in the vicinity of the wells and as a result, the draw-down of the water table occurred at a comparatively rapid rate. When pumping ceased water percolated into the area around the wells only slowly through the less permeable material, and hence the recovery of the water table was relatively slow.

If the part of the hydrograph for August 9 and that for the first half of August 10 are projected with the same slope to August 16, presumably the normal seasonal rate of decline of the water table in the area, the projected water level will be found to be only about 0.01 foot above the recorded water level. Thus it is inferred that the pumping caused only a small net decline of the water table and that the ground-water supply of the Brule in that area is considerable, even though the slow rate of recovery of the water table would seem to indicate otherwise. 


\section{PLUCTUATIONS CAUSED BY OHANGIS IN ATMOSPEIRIC PRIESSURE}

Where the ground water is confined under pressure or where the ground is frozen or saturated with moisture, changes in atmospheric pressure may not be readily transmitted through the ground to the water in the zone of saturation. However, changes in air pressure usually may be transmitted directly down to the water level inside the well casing, and thus a differential pressure sometimes is created between the water inside and outside of the well casing that forces water either out of the formation into the well or into the formation from the well. When the atmospheric pressure decreases, the water level in the well rises, and, conversely, when the atmospheric pressure increases, the water level in the well declines. The water level outside the well may, however, remain practically stationary while these fluctuations are occurring in the well.

The hydrograph of well 201, obtained by an automatic water-stage recorder, and the barometric trace at North Platte, converted to feet of water, for the period January 3 to January 10, 1938, are plotted in figure 11. An inspection of the two curves shows that the major fluctuations of water level in well 201 for the period were doubtless caused by changes in atmospheric pressure although the correlation between the two graphs is not particularly good because the atmospheric pressure was recorded about 150 miles east of the well. Many, if not all, of the minor fluctuations of water level probably were caused by small local changes in atmospheric pressure, which were not recorded at North Platte. The three major rises of water level, January 3-5, 6-8, and 9-10, average 42 percent of the corresponding declines of the water barometer, and the two major declines of water level, January 5-6, and 8-9, average 63 percent of the corresponding rises of the water barometer. The water level in the well, therefore, functioned about 52.5 percent effective as a barograph. The greater percentage of effectiveness on rising atmospheric pressure, or declining water level in well, probably is due to the fact that the trend of the water level in the well was downward for the period. Fluctuations of water level in well 201 caused by changes in atmospheric pressure were recorded by the automatic water-stage recorder throughout the period of investigation. Therefore, freezing of the ground or temporary saturation of the upper few feet of soil probably was not instrumental in causing the water level in the well to fluctuate with changes in atmospheric pressure. Rather, the ground water at the well probably is under artesian pressure, and the transmission of changes in atmospheric pressure to the zone of saturation probably is impeded by the massive part of the Brule, which functions as the confining bed for the water in the creviced part of the formation.

\section{MOVEMENT OF GROUND WATER}

The ground water in Scotts Bluff County is almost everywhere moving slowly but persistently from areas of high to those of low altitude or head. The general direction of movement is toward points of discharge, such as springs, wells, streams, or areas of ground-water transpiration, and is shown by the direction of the hydraulic gradient. The rate of groundwater movement is proportional to the hydraulic gradient and the permeability of the formation and the volume of percolation is proportional 


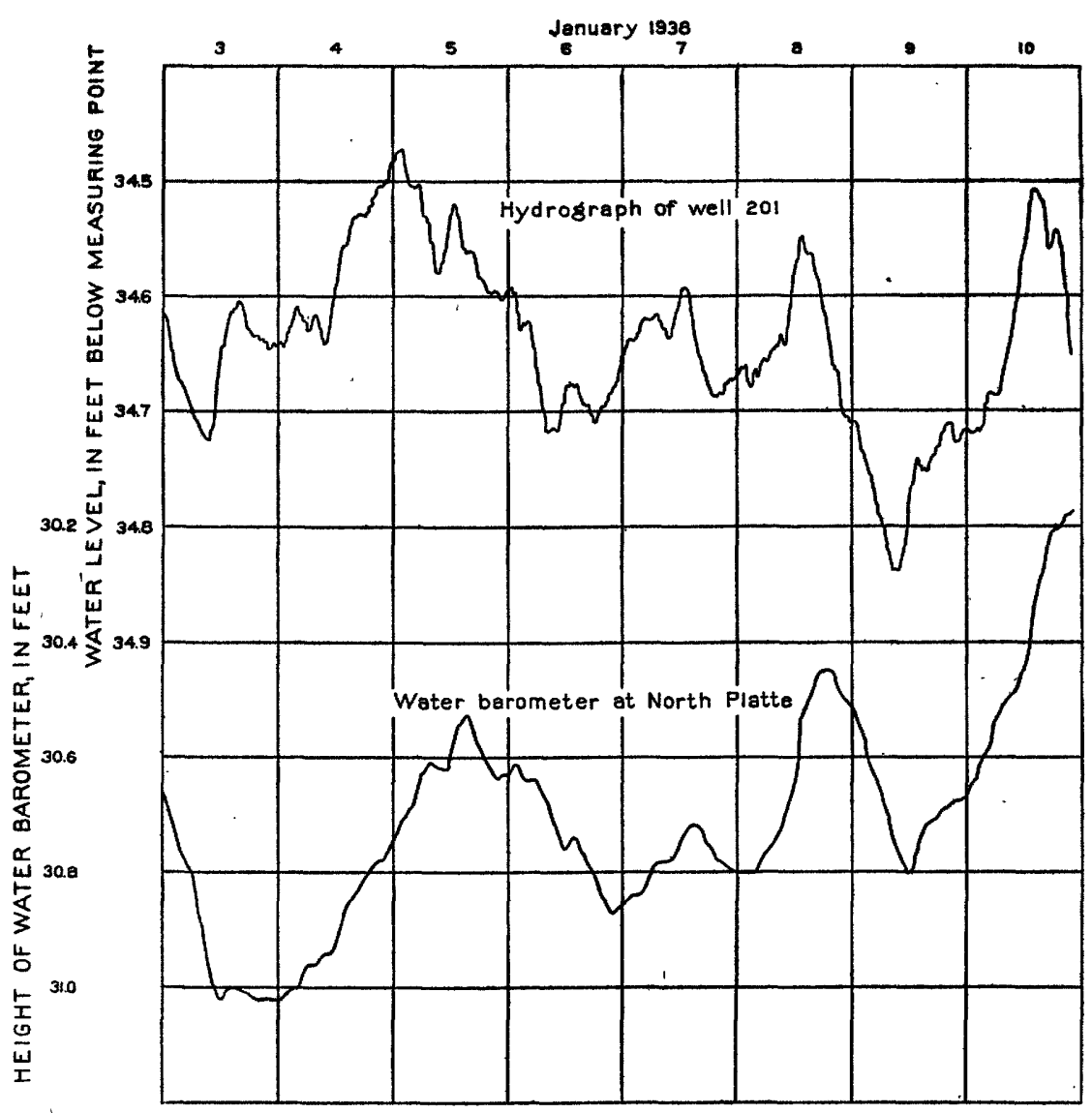

FuOURE 11.-Graph from automatio water-atage recorder showing fluetuations of water lovel in well 201 caused by changes in atmospheric preseure.

to the rate of percolation and the cross-sectional area of the formation.

The direction of movement of the ground water is usually shown by contour maps of the water table or piezometric surface. The movement is at right angles to the contours, which are lines of equal altitude drawn on the water table or piezometric surface. Such lines, with an interval of 20 feet, have been drawn for Scotts Bluff County from data obtained in this investigation on about 340 wells (pl. 3).

The depths to water level were measured during a canvass of representative wells in the county, which required several months for completion. Because the measurements were made over an extended period during which the ground-water level fluctuated considerably, it was not possible to use the measurements directly for constructing the contour map. About 120 of the wells were revisited from November 24 to 29, 1937 , and the depth to water level in them remeasured. It was then possible to determine the change in water level that had occurred since each well was measured previously and accordingly to adjust by inter- 
polation the depth to water level in wells that were not revisited in November. The contour map therefore represents conditions near the end of November 1937 that were partly observed and partly interpolated.

The altitude of the water level in each well was determined by subtracting the depth to water level from the altitude of the measuring point. The depth to water level was determined in the manner described on page 90 and the altitude of the measuring point was determined by altimeters -instruments designed to measure air pressure, in feet above sea level. The determination of differences in altitude by means of altimeters is not a precise method, and hence the altitudes so determined are only approximate. Inaccuracies are caused chiefly by changes in atmospheric pressure and temperature and by difficulties in reading the instruments. Errors caused by changes in atmospheric pressure were reduced by maintaining one altimeter at a bench mark of known altitude while two other altimeters were taken to the wells. The altimeter at the bench mark was read every 5 minutes and the instrument readings made at the wells were corrected for changes in atmospheric pressure observed at the bench mark. A correction for air temperature was applied to all measurements, and at least 3 readings were taken at each observation. Although the method of determining the altitude of the measuring points is not precise, the errors introduced probably are comparatively small and the contour lines shown on plate 3 probably indicate the general direction of movement of the ground water.

The water levels used for drawing the contour lines were all taken from wells that penetrate the Pleistocene or Recent sand and gravel or the Brule formation. The map therefore shows only the general direction of movement of the ground water in these formations and not in the Lance or other underlying beds. Since water occurs in the Brule chiefly in cracks and fissures, the contours in some places may indicate movement where there is none. The map is referred to as a contour map of the water table although at places it doubtless shows contours on the piezometric surface.

The contour map shows that the general direction of movement of the ground water in Scotts Bluff County is toward the North Platte River. Water percolates into the area from Sioux County at the north and from Banner County at the south. Percolation from Banner County is, however, limited to the eastern part of the area because the movement in southeastern Scotts Bluff County is southward toward Pumpkin Creek Valley from the high land that divides that valley from the North Platte Valley. There is practically no movement of ground water into the county from Wyoming or out of the county into Morrill County except beneath the North Platte River and the bottom lands adjacent to the river.

The contour map shows that in some places the water table is comparatively flat and smooth, that in others it is steep and uneven, and that in still others it forms mounds, ridges, and valleys. The form of the water table, moreover, is changing continuously, rising where water is being added to the formations and falling where water is being discharged from them. The movement of the ground water in the county, which occurs under a three-dimensional system of hydraulic gradients, is thus exceedingly complex in detail.

The hydraulic gradients of the water table in the Brule average about 50 feet to the mile throughout much of the county; in the alluvium the 
gradients are much less, averaging only about 7 feet to the mile along the North Platte River. The contour lines along the bluffs of the valley show steep hydraulic gradients, several hundred feet to the mile at places. It is possible that the water table beneath the bluffs may not be continuous with that in the valley and hence the indicated steep gradients may not actually exist.

The field coefficient of permeability of the Pleistocene and Recent sand and gravel has been computed to be about 1,400. (See p. 82.) Test holes drilled in connection with this investigation show that the valley fill of sand and gravel beneath the North Platte River at Mitchell has a cross-sectional area equivalent to a section about 2.5 miles wide and $\mathbf{1 1 0}$ feet thick. Thus under the hydraulic gradient of 7 feet to the mile shown on plate 3 , the underflow in this material amounts to $1,400 \times 7 \times 110 \times 2.5=2,695,000$ gallons of water a day-about 3,000 acre-feet a year. It it is assumed that the valley fill has an effective porosity of 25 percent, the average velocity of the ground water may be computed to be 1 foot a day. Ground water percolating into Scotts Bluff County from Wyoming through the valley fill will, therefore, reach the Morrill County line, about $\mathbf{4 0}$ miles indirectly east, only after about 575 years.

The average field coefficient of permeability of the Brule formation has been computed to be about 575 (see p. 85) on the basis that the average thickness of the water-filled creviced part of the formation is 100 feet. The volume that will percolate through each mile of Brule 100 feet thick under a gradient of 50 feet to the mile will be $575 \times 50 \times 100=2,875,000$ gallons of water a day-3,220 acre-feet a year. The velocity of the ground water in the Brule cannot be determined because no information is available on the pore space through which the water moves. The movement, however, is doubtless much faster than it is in the valley fill.

\section{GROUND-WATER DISCHARGE}

\section{GENERAL CONDITIONS}

Ground water is discharged from Scotts Bluff County by wells, plants, evaporation, springs, streams, and underflow. The rate at which it is withdrawn varies with many factors, such as the depth to the water table, the nature of the vegetative cover, and the season of the year. Local differences in conditions cause more ground water to be discharged from some parts of the county than from others. For instance, more water is withdrawn from wells in and near the towns where the pumpage for industrial and municipal supply is larger than is withdrawn at other places where the pumpage is only for domestic and stock purposes. Large quantities of water are withdrawn by plants from the zone of saturation on the bottom land along the North Platte River and at other places where the water table is close to the land surface, but only very small quantities, if any, are withdrawn by plants where the.water table is far below the surface. Evaporation from the zone of saturation takes place chiefly from the land lying immediately along streams where the capillary fringe extends to or very near the land surface. Discharge of ground water by streams and springs is, of course, limited to areas where the topography is favorable. 


\section{DISCHARGE TROM WELIS}

\section{FARM WELLS}

Most of the rural residents of Scotts Bluff County obtain supplies for domestic and stock purposes from small wells that are equipped with pitcher, force, or rotary pumps. The wells, of which there are estimated to be about 1,800, are operated chiefly by windmills, but a few are operated by gasoline engines or by electric motors. Most of them also can be pumped by hand. The wells in general yield only a few gallons a minute and are ordinarily pumped only at intervals when water is needed. Records for about 20 percent of the wells in the county appear in the table at the end of this report.

The yield of four typical farm wells of the area (Nos. 17, 150, 209, and 277), measured under normal conditions of operation, and the number of strokes of the pumps required to withdraw a gallon of water are given in the accompanying table. Wells 150,209 , and 277 were pumped by windmills and well 17 was pumped by a gasoline engine.

The discharge of the four wells averages about 2.7 gallons a minute. The wells are probably not pumped on the average more than 4 hours a day. The annual pumpage of all the farm wells probably does not exceed 1,300 acre-feet of water a year.

Data on the yreld of farm wells

\begin{tabular}{|c|c|c|c|}
\hline $\begin{array}{l}\text { Well } \\
\text { No. }\end{array}$ & Trials & Number of pump strokes per gallon & Discharge in gallons per minute \\
\hline \multirow[t]{2}{*}{17} & $\begin{array}{l}\text { First. } \\
\text { Second... } \\
\text { Third... }\end{array}$ & $\begin{array}{l}12 \\
11 \\
10\end{array}$ & $\begin{array}{l}3.3 \\
3.6 \\
4.0\end{array}$ \\
\hline & Average & 11 & 3.6 \\
\hline \multirow[t]{2}{*}{150} & $\begin{array}{l}\text { First. } \\
\text { Second..._- } \\
\text { Third...- }\end{array}$ & $\begin{array}{l}11 \\
10 \\
13\end{array}$ & $\begin{array}{l}1.7 \\
1.2 \\
1.3\end{array}$ \\
\hline & Average.... & 11.3 & 1.7 \\
\hline \multirow[t]{2}{*}{209} & $\begin{array}{l}\text { First } \\
\text { Second } \\
\text { Third }\end{array}$ & $\begin{array}{l}9 \\
9 \\
9\end{array}$ & $\begin{array}{l}4.2 \\
3.5 \\
4.2\end{array}$ \\
\hline & Average. & 9 & 4.0 \\
\hline \multirow[t]{2}{*}{277} & $\begin{array}{l}\text { First. } \\
\text { Second. } \\
\text { Third... }\end{array}$ & $\begin{array}{l}16 \\
16 \\
17\end{array}$ & $\begin{array}{l}1.7 \\
1.7 \\
1.4\end{array}$ \\
\hline & Average & 16.3 & 1.6 \\
\hline
\end{tabular}

\section{IRRIGATION WELLS}

Forty-two irrigation wells were located in Scotts Bluff and southwestern Sioux Counties by the canvass of wells made in 1937 in connection with this investigation. With the exception of well 305 , which taps water in the Brule formation, all the wells are believed to draw water from the Pleistocene and Recent sand and gravel. Most of the wells are near the North Platte River or on the third terrace of the river. They are used chiefly as an auxiliary supply for irrigation since most of the farms on which the wells are situated are served also by water diverted from the 
North Platte River. Some of the wells are not operated during years when the supply of surface water is large.

The accompanying table gives data on the operation of 28 irrigation wells in the area in 1936. Information on the other 14 wells is not given either because it could not be obtained or because the wells were not operated in that year. The table shows that about 1,280 acres of crops in Scotts Bluff County and 705 acres of crops in southwestern Sioux County were irrigated in part by water pumped from the wells. Irrigation was principally for sugar beets and potatoes, although some water also was pumped for corn, hay, grain, beans, and garden truck. It is estimated that pumpage from the wells in 1936 was 1,632 acre-feet, of which about 1,246 acre-feet was withdrawn in Scotts Bluff County. The lowest yield reported by any well in the table is $\mathbf{4 0 0}$ gallons a minute; the highest is 1,400 gallons a minute. The average yield of 25 of the wells is 860 gallons a minute.

Data on the operation of irrigation wells in Scotts Bluff and southwestern Sioux Counties in 1986

Scotts Bluff County

\begin{tabular}{|c|c|c|c|c|c|c|}
\hline $\begin{array}{l}\text { Well } \\
\text { No. }\end{array}$ & $\underset{\substack{\text { Arrea } \\
\text { (acres) }}}{\text { argated }}$ & $\begin{array}{l}\text { Operation } \\
\text { in 1936 } \\
\text { (days) }\end{array}$ & $\begin{array}{l}\text { Reported average } \\
\text { daily operation } \\
\text { (hours) }\end{array}$ & $\begin{array}{c}\text { Estimated } \\
\text { pumping } \\
\text { rate } \\
\text { (gallons } \\
\text { a minute) }\end{array}$ & $\begin{array}{c}\text { Estimated. } \\
\text { pumpage } \\
\text { in } 1936 \\
\text { (acre- } \\
\text { feet) }\end{array}$ & Crops irrigated \\
\hline $\begin{array}{l}26 \\
49 \\
96 \\
98 \ldots \\
99 . \ldots\end{array}$ & $\begin{array}{lr}1 & 160 \\
1 & 40 \\
& 15 \\
1 & 70 \\
1 & 80\end{array}$ & $\begin{array}{l}30 \\
10 \\
20 \\
1.5 \\
35\end{array}$ & $\begin{array}{l}14 \\
12 \\
10 \\
24 \\
24\end{array}$ & $\begin{array}{r}1,000 \\
650 \\
450 \\
1,350 \\
1,350\end{array}$ & $\begin{array}{r}77 \\
14 \\
17 \\
9 \\
209\end{array}$ & \multirow{11}{*}{$\begin{array}{l}\text { Garden truck. } \\
\text { Beets, corn, alialfa, } \\
\text { beans, grain. } \\
\text { Garden truok. } \\
\text { Beets, potatoes, corn, } \\
\text { hay, grain, } \\
\text { Garden truek, lawn. } \\
\text { Beets, potatoes. } \\
\text { Beets, potatoes. } \\
\text { Beets, potatoes. } \\
\text { Beets, potatoes. } \\
\text { Corn, rye, potatoes, } \\
\text { beans, alfalfa, gar- } \\
\text { den truck. } \\
\text { Beets, potatoes, grain, } \\
\text { hay. } \\
\text { Beeta, hay, }\end{array}$} \\
\hline $142 \ldots$ & $1 \quad \begin{array}{r}3 \\
140\end{array}$ & & & & & \\
\hline $156 \ldots$ & .5 & & & & & \\
\hline $\begin{array}{l}188 \ldots \ldots . . . . \\
185 \\
187 . \ldots \ldots\end{array}$ & 30 & \multirow{5}{*}{$\begin{array}{l}14 \\
35 \\
14 \\
21 \\
14 \\
12 \\
14 \\
35 \\
30 \\
51 \\
42\end{array}$} & \multirow{5}{*}{$\begin{array}{l}14 \\
14 \\
14 \\
24 \\
14 \\
24 \\
14 \\
14 \\
24 \\
12 \\
17\end{array}$} & \multirow{5}{*}{$\begin{array}{r}1,000 \\
1,160 \\
400 \\
1,200 \\
1,100 \\
1,280 \\
750 \\
900 \\
500 \\
1,400 \\
500\end{array}$} & \multirow{5}{*}{$\begin{array}{r}36 \\
105 \\
14 \\
111 \\
40 \\
68 \\
27 \\
81 \\
66 \\
158 \\
66\end{array}$} & \\
\hline 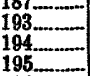 & $\begin{array}{rr}1 & 160 \\
1 & 40 \\
1 & 39\end{array}$ & & & & & \\
\hline ב......... & 165 & & & & & \\
\hline ב-ב.......... & 150 & & & & & \\
\hline $270 \ldots$ & 47 & & & & & \\
\hline 276 & & 2 & 16 & 625 & 4 & \\
\hline & 120 & 60 & 10 & 625 & 69 & \\
\hline $329 \ldots \ldots$ & 40 & 8 & 16 & 1,235 & 29 & \\
\hline Total & 11270.5 & & & & 1,246 & \\
\hline
\end{tabular}

Southwestern Sloux County

\begin{tabular}{|c|c|c|c|c|c|c|}
\hline $225 \ldots . . . .$. & 1110 & & 14 & 500 & 28 & Beets, potatoes, corn. \\
\hline 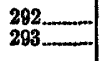 & $\begin{array}{l}1160 \\
1120\end{array}$ & $\begin{array}{l}35 \\
42\end{array}$ & $\begin{array}{l}24 \\
14\end{array}$ & $\begin{array}{r}850 \\
1,235\end{array}$ & $\begin{array}{l}131 \\
134\end{array}$ & Potatoea \\
\hline 296. & $\begin{array}{l}1240 \\
175\end{array}$ & $\begin{array}{l}21 \\
10\end{array}$ & $\begin{array}{l}24 \\
24\end{array}$ & $\begin{array}{l}760 \\
500\end{array}$ & $\begin{array}{l}71 \\
22\end{array}$ & \\
\hline Total & 1705 & & & & 386 & \\
\hline
\end{tabular}

1 Irrizated in part by surface water. 
Most of the irrigation wells have been drilled during the past few years (1930-1937) by local drillers who devote part or all of their time to well construction and who use their own equipment. A few of the wells have been drilled by farmers using improvised equipment. The irrigation wells are mostly shallow, only 2 out of 41 , for which information of this kind is available, being more than 100 feet deep. More than half of them are drilled to depths between 40 and 70 feet, the average being 59 feet. Their diameter ranges from 6 to 42 inches but is 24 inches in 25 of the wells.

Where the water table is only a few feet below the land surface, as beneath the bottom lands along the North Platte River, most of the wells are equipped with centrifugal pumps, but where the water table is deeper, as beneath the third terrace, the wells are equipped with deep-well turbine pumps. Data regarding the type of irrigation pump was obtained for 41 irrigation pumping plants, of which 20 are of the centrifugal type and 21 of the turbine type.

Most of the irrigation pumping plants are operated by tractors. There are 10 electric installations and 8 power units of other types chiefly automobile engines or stationary gasoline engines. Each of the pumping plants draws water from only a single well, except that at well 187 , in the SW1 $1 / 4$ SW1 14 sec. 3, T. 22 N., R. 56 W., which pumps from three 6-inch wells that are connected to a common suction pipe.

\section{FLOWING WELLS}

Thirty-three flowing wells, the records of which appear in an accompanying table, were located in Scotts Bluff County during the canvass of wells (see pl. 3). Wells F-1 and F-2, at Gering, and wells F-3 and F-4, at Scottsbluff, penetrate the Lance at depths of more than 200 feet. Wells F-5, F-6, and F-7 tap water under artesian pressure in the Brule about 3 miles south of Mitchell. The rest of the wells receive water from the Lance formation at shallow depths south of Lyman. The wells are $31 / 2$ to 8 inches in diameter and 71 to 560 feet deep.

Measurements of flow and water temperature were made on most of the wells. As is shown by the accompanying table, the flow of the wells south of Lyman is small, ranging from a trickle to 1.2 gallons a minute. The flow of 19 of these wells averages only 0.4 gallon a minute. The aggregate flow of the 3 wells tapping the Brule formation south of Mitchell is about 900 gallons a minute. These wells, however, are allowed to flow only in the summer. The wells at Scottsbluff and Gering have been abandoned, but it is reported that those at Scottsbluff flowed 25 gallons a minute when drilled. No information on the flow of the wells at Gering was obtained. The aggregate flow of all the wells probably does not exceed 400 acre-feet a year.

The temperature of the water from the flowing wells ranged from $46^{\circ} \mathrm{F}$. to $551 / 2^{\circ} \mathrm{F}$. and averaged about $52^{\circ} \mathrm{F}$. for all the wells. The rather large range in measured temperature indicates that some heating or cooling of the water probably occurred in the well casings or outlet connections, because it is not likely that the temperature of the water in the formation would differ so greatly from place to place. 


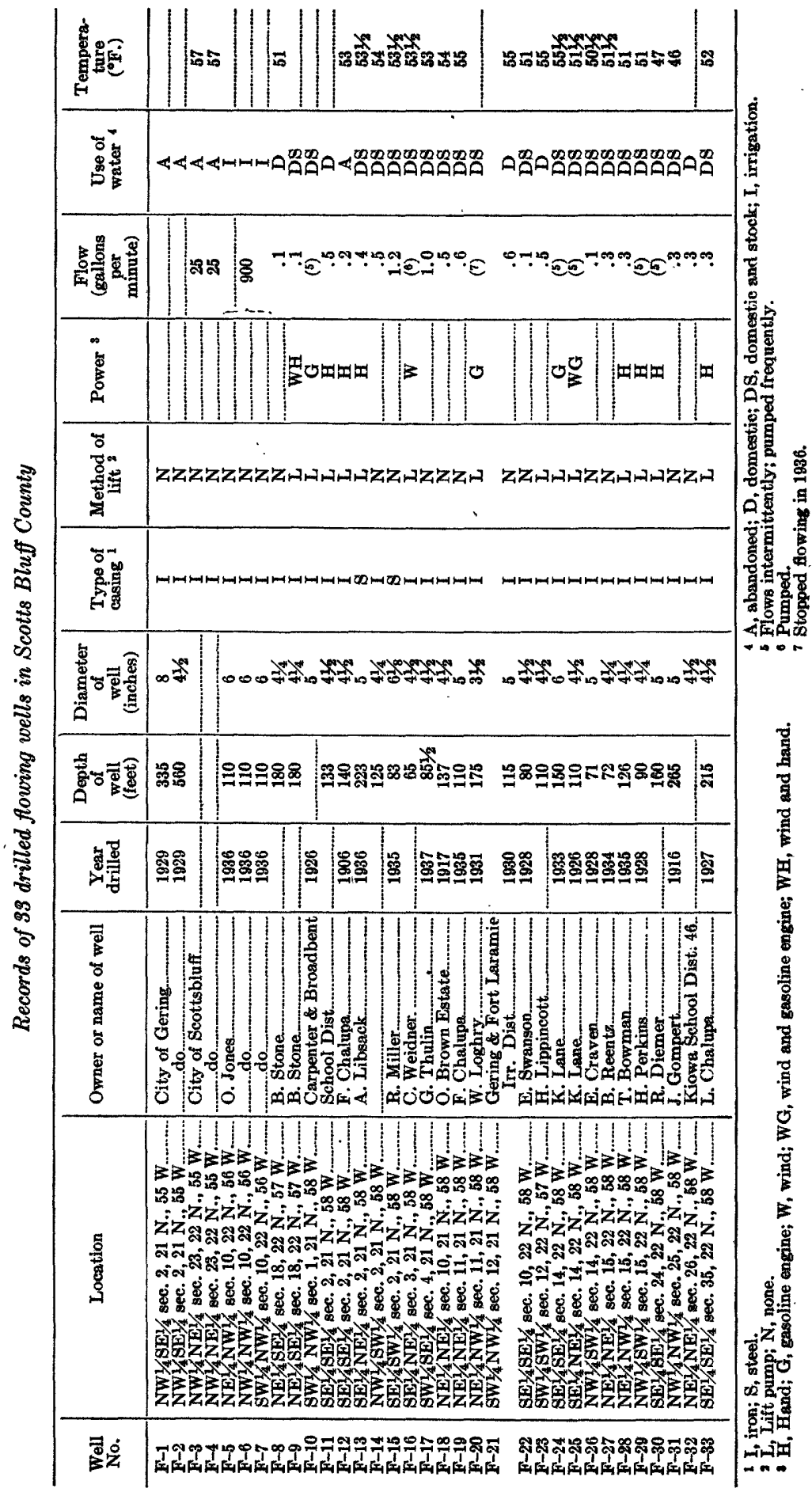




\section{INDUSTRIAL WELLS}

The largest quantities of ground water used for industrial purposes in Scotts Bluff County are pumped at the factories of the beet-sugar companies in Scottsbluff, Gering, and Minatare. The water supply for the Burlington Railroad is obtained from wells at Scottsbluff, and the supply for the Union Pacific Railroad is obtained from wells at Gering and Lyman. The other industrial ground-water supplies of the county are all pumped from wells in or near Scottsbluff, and include those of the Western Public Service Co., Finke Creamery, Platte Valley Packing Co., Scottsbluff Rendering Plant, Ideal Laundry, and the Terry Carpenter enterprises. Water used for industrial purposes in the smaller towns in Scotts Bluff County is furnished by the municipal supply systems. All the industrial wells tap water in the Pleistocene and Recent sand and gravel. Records of some of the industrial wells are given in the table on page 112 .

Water for the factory of the Great Western Sugar Company at Scottsbluff is obtained from fourteen 12-inch wells which are connected to two pumps. In 1937, about 1,350 gallons of water a minute was pumped continuously from the wells for 53 days beginning October $7-a$ total pumpage of about 103,000,000 gallons. The wells were not used during the rest of the year. Water for the operation of the factory is obtained also from Winter Creek.

The entire water supply of the sugar factory at Minatare is obtained from 24 wells situated about 100 feet apart on a line about at right angles to the direction of the underflow. The wells are 14 inches in diameter and are connected to 3 centrifugal pumps. In 1937 the wells were pumped continuously for 54 days, beginning October 7 , at a rate of about 5,800 gallons a minute. The pumpage for the year amounted to about $380,000,000$ gallons.

Formerly the water supply of the sugar factory at Gering was obtained from 41 wells, but now the water needed for processing the beets is obtained from the North Platte River and the wells are used only as an emergency supply. A few of the wells were pumped for about 2 days in 1937.

The supply for the Burlington Railroad is pumped from a well 12 inches in diameter and 90 feet deep, situated about 2 blocks east of the depot in Scottsbluff. An elevated steel tank at the site of the well provides storage for 50,000 gallons of water, most of which is delivered to locomotives on the line or to the roundhouse of the railroad. The pumpage in 1937 totaled about $35,000,000$ gallons.

The Union Pacific Railroad operates wells at Gering, Lyman and McGrew. The pumping plant at McGrew was once used to supply locomotives but now is used only to furnish water for the depot. The supply at Gering is obtained from 5 wells just northwest of the roundhouse at the north edge of the town. Four of the wells are 6 inches in diameter and 90 feet deep; the other well has the same depth but is 24 inches in diameter. All five wells are connected to one pump. It is estimated that the combined pumpage of the plants at Gering and Lyman in 1937 amounted to about 23,000,000 gallons.

The Western Public Service Co. obtains water at Scottsbluff for making ice and for condenser use from two wells drilled in 1933.' The well used in connection with the production of ice is $\mathbf{1 0}$ inches in diameter 


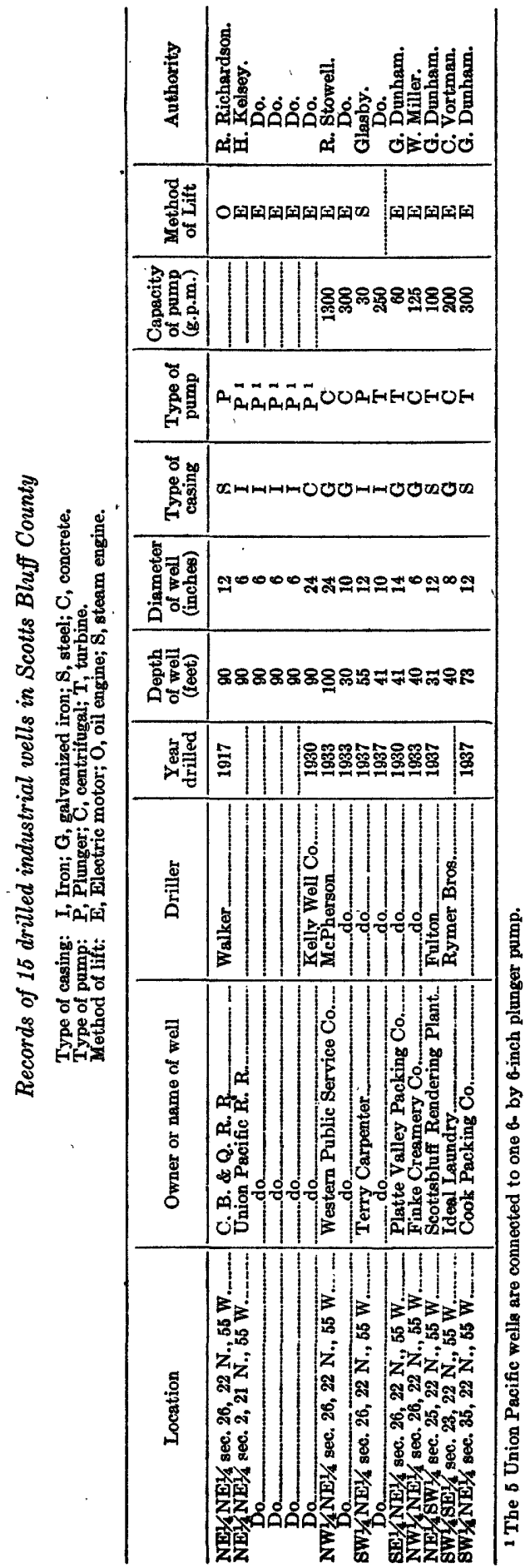


and 30 feet deep and is equipped with a 3 -inch vertical centrifugal pump with a rated capacity of 300 gallons a minute. The well pumped to supply water for condenser use is 24 inches in diameter and 100 feet deep and is equipped with a 6 -inch centrifugal pump with a rated capacity of 1,300 gallons a minute. The well at the ice plant is pumped about 12 hours a day for about half the year, and the other well is pumped continuously except for 12 to 14 days out of the year. It is estimated that the combined pumpage of the two wells was about $200,000,000$ gallons in 1937.

The Finke Creamery in Scottsbluff pumps water from a well that is 6 inches in diameter and 40 feet deep. It is equipped with a 11/2-inch rotary pump and an electric motor. Pumpage in 1937 is estimated to have been about $10,000,000$ gallons.

The Platte Valley Packing Co. in Scottsbluff is supplied with water from a well 14 inches in diameter and 41 feet deep, which is equipped with a turbine pump and an electric motor. Pumpage from this well in 1937 amounted to about $14,000,000$ gallons.

The Scottsbluff Rendering Plant in Scottsbluff pumps water from a well 12 inches in diameter and 31 feet deep, which was completed in July 1937. This well is equipped with a 4-inch turbine pump. It is estimated that about $7,000,000$ gallons of water was pumped from the well during the time it was in operation in 1937.

The Ideal Laundry in Scottsbluff obtains its water supply from a well 8 inches in diameter and 40 feet deep. The pumpage in 1937, based on the water requirements of washing machines, boilers, and other equipment, is estimated to have been about 2,000,000 gallons.

Two wells were drilled in Scottsbluff in 1937 for the Terry Carpenter enterprises to supply water for a refinery and for other uses. The first well, completed in April, is 12 inches in diameter and 55 feet deep and is equipped with a plunger pump operated by a steam engine. The second well, drilled in July, is 10 inches in diameter and 41 feet deep and is equipped with a turbine pump operated by an electric motor. The second well was operated almost continuously from the time of its completion to the end of 1937 , but the first well was operated only infrequently as an auxiliary supply. The combined pumpage of the two wells in 1937 was about $50,000,000$ gallons.

The quantity of ground water pumped for industrial use in Scotts Bluff County in 1937, based on the individual estimates given in the previous paragraphs, totals $824,000,000$ gallons - about 2,530 acre feet.

\section{MUNICIPAL WELLS}

All the towns in Scotts Bluff County obtain their water supplies from wells. Scottsbluff, Gering, Mitchell, Morrill, Minatare, Lyman, and Henry have public water-supply systems, and Melbeta, McGrew, and Haig obtain water from private domestic wells. Records of the municipal wells are given in the accompanying table.

The city of Scottsbluff obtains its water supply from four wells, three of which are in the south part of town and the fourth and newest well being at the north edge of town. The wells are approximately 100 feet deep and from 14 to 18 inches in diameter. All the wells tap the Pleistocene and Recent sand and gravel. 

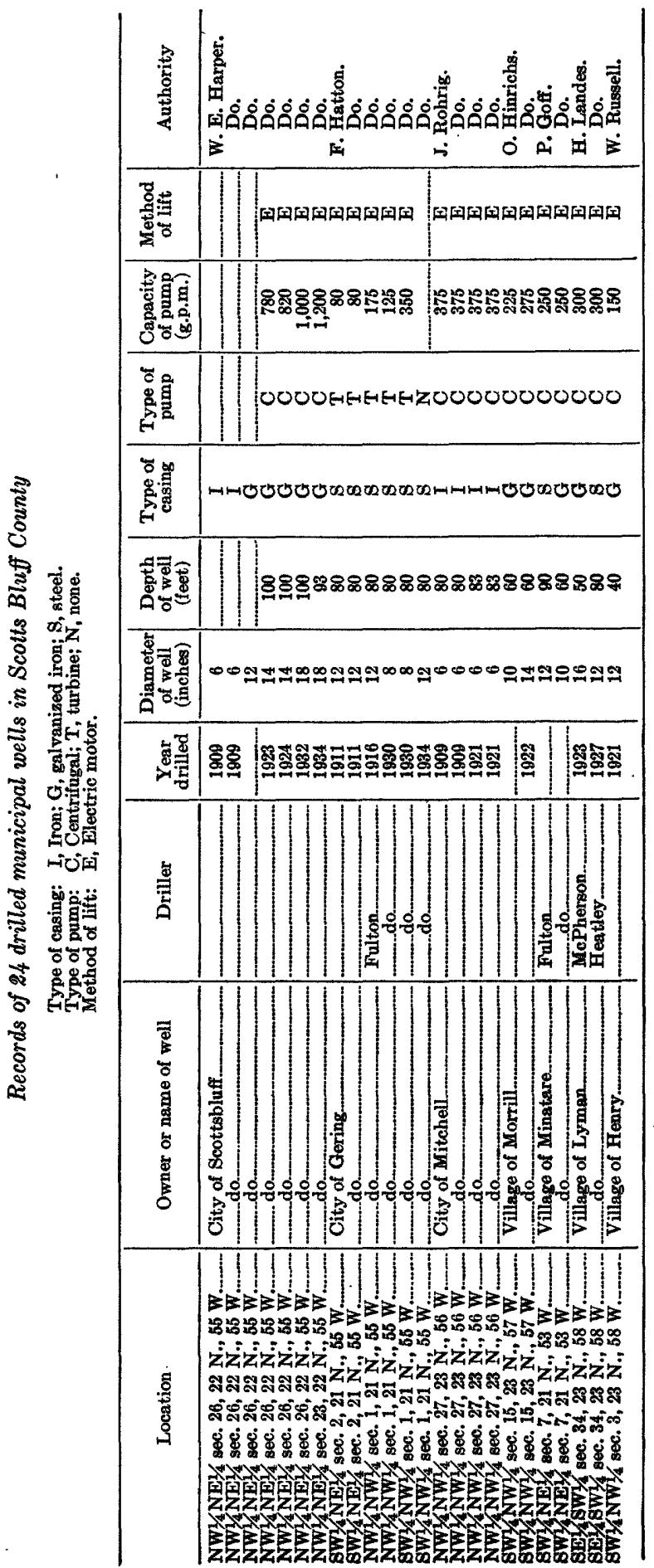
Water is discharged from the wells directly into the mains by four pumps, which have a maximum combined capacity of about 3,000 gallons per minute. Two elevated tanks with storage capacities of 300,000 gallons and 100,000 gallons are connected to the system. The average daily pumpage is about $1,200,000$ gallons and the maximum daily pumpage about 2,750,000 gallons. It is estimated that the pumpage in 1937 amounted to approximately $440,000,000$ gallons, indicating a per capita pumpage of about 140 gallons a day.

Gering is supplied by 2 wells that are 8 inches in diameter and 80 feet deep and by 4 wells that are 12 inches in diameter and 80 feet deep. Two of the 12-inch wells are connected to one pump and the others are operated individually, giving a combined pumping capacity of about 750 gallons per minute. Water is pumped directly into the mains and into an elevated steel tank having a capacity of 75,000 gallons. The average daily pumpage is about 260,000 gallons, and the maximum daily pumpage is about 750,000 gallons. Pumpage in 1937 was about $95,000,000$ gallons.

The city wells at Gering encountered the Brule formation at depths of 40 to 44 feet, penetrating 8 to 9 feet through sand and the remaining distance through a fine-grained alluvium consisting largely of reworked Brule. The capacity of the wells therefore is rather low, and it is reported that their yield declines considerably when an attempt is made to pump them faster.

Mitchell obtains its water supply from 4 wells, 6 inches in diameter and from 80 to 83 feet deep, which are believed to tap only Pleistocene and Recent sand and gravel. The wells are connected in pairs to two centrifugal pumps, which have a combined capacity of 750 gallons per minute. The water from the wells is discharged directly into the distribution system and into an elevated steel tank having a capacity of 100,000 gallons. The average daily pumpage is about 107,000 gallons. It has been estimated that the municipal pumpage in 1937 was about $39,000,000$ gallons.

The public supply of Morrill is pumped from two wells, one 10 inches in diameter and the other 14 inches. Both are 60 feet deep and are reported to have been drilled entirely in sand and gravel. The wells are equipped with two centrifugal pumps having a combined capacity of about 500 gallons per minute. Water is pumped directly into the mains; storage is provided by an elevated steel tank with a capacity of 50,000 gallons. The average daily pumpage is about 102,000 gallons. In 1937 the pumpage was about $37,000,000$ gallons.

The water supply for Minatare is obtained from two wells, one 12 inches in diameter and 90 feet deep, the other 10 inches in diameter and 60 feet deep, which are connected to one centrifugal pump having a capacity of 250 gallons per minute. Both wells were drilled entirely in sand and gravel. An electrically driven triplex pump with a rated capacity of about 300 gallons per minute is maintained at the pumping plant as auxiliary equipment. Water is pumped directly into the mains and into an elevated tank having a capacity of 50,000 gallons. It is estimated that the pumpage in 1937 amounted to about $30,000,000$ gallons, or about 82,000 gallons a day.

The municipal supply for Lyman, which was established in 1923 is obtained from two wells, one 16 inches in diameter and 50 feet deep, the other 12 inches in diameter and 80 feet deep, which penetrated through about 80 feet of Pleistocene and Recent sand and gravel to the under- 
lying Brule formation. Water is pumped directly into the mains and into an elevated steel tank, which has a capacity of 100,000 gallons. The average daily pumpage in 1937 was about 30,000 gallons and the maximum daily pumpage about 100,000 gallons. Pumpage for the year amounted to about $11,000,000$ gallons.

The municipal supply for Henry is pumped from a well, 12 inches in diameter and 40 feet deep, which is equipped with a centrifugal pump having a capacity of 150 gallons per minute. The well taps water in the Pleistocene and Recent sand and gravel. Water is pumped into a steel standpipe, which has a capacity of 16,000 gallons, from which it is carried through the water mains by gravity. Pumpage in 1937 is estimated to have been about $3,500,000$ gallons.

The total pumpage for municipal supply in Scotts Bluff County in 1937 , based on the estimates just given, amounts to $655,500,000$ gallons, or about 2,000 acre-feet. This quantity of water would be discharged in a year by one well pumping continuously at a rate of about 1,245 gallons per minute.

\section{EVAPO-TRANSPIRATION}

A part of the rain and snow that fall on the ground eventually enters the interstices of the earth. After penetrating the first few feet of soil this water either may remain there for some time or may percolate downward to the water table, the alternative depending upon the amount of water held in the soil. If the amount of water in the belt of soil moisture, perhaps the upper 6 or 7 feet of soil, has been depleted by evaporation and by growing plants, water that percolates down from the surface is retained in this belt until the amount in the soil is greater than can be beld by molecular attraction against the pull of gravity. Surplus water will then move down through it, most of which will eventually be added to the water table. For a distance of a few feet above the water table some of the interstices are filled with water that is continuous with the zone of saturation but is held above that zone by capillarity acting against gravity. This belt above the zone of saturation is called the capillary fringe. Where the water table is close to the land surface, the capillary fringe may extend upward to the belt of soil moisture, but where the water table is deep, there is an intermediate belt, ${ }^{48}$ which contains water held chiefly by molecular attraction. The intermediate belt functions chiefly as a passageway for water from the belt of soil moisture to the water table.

Where the water table is at or very near the land surface, water from the zone of saturation may be discharged directly into the atmosphere by evaporation from the capillary fringe. The roots of most plants in such areas also extract water from the capillary fringe. Where the water table is somewhat deeper, but within 5 to 10 feet of the surface, evaporation is relatively unimportant. However, many plants, including field crops, may yet obtain much of the water needed for their growth by extending their roots to the capillary fringe. Where the water table is still deeper, the plants, with the exception of certain trees and deeprooted phreatophytes like alfalfa, are not able to send their roots to the capillary fringe and hence must depend for their growth on moisture in

48 Meinzer, O. E., The occurrence of ground water in the United States: U. S. Geol. Survey Water-Supply Paper 489, p. 82, 1923 . 


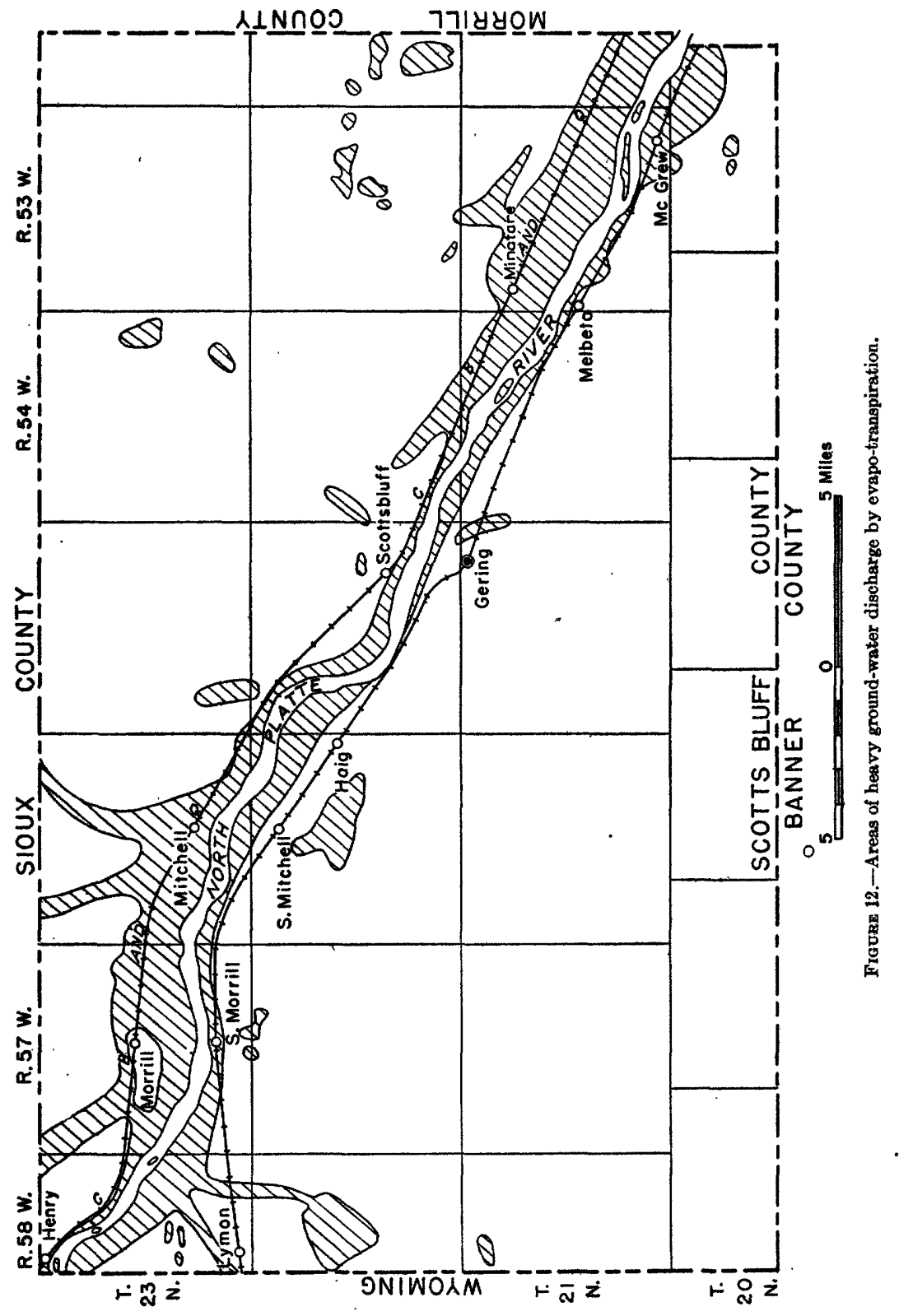


the belt of soil water. Discharge of ground water by evapo-transpiration occurs, therefore, chiefly in areas where the water table is not far below the surface.

The evaporation and transpiration of ground water from the zone of saturation occurs at many places in Scotts Bluff County because, as previously (p. 86-87) pointed out, the water table at many places is close to the surface, even in some areas that are far above river level. Thus, areas of evaporation and transpiration literally dot the county. Many such areas are easily recognized by superficial examination for they appear as bogs and marshes containing especially luxuriant growths of upland grasses and typical marsh plants like cattails. In Scotts Bluff County these areas which have largely developed since irrigation with surface water was begun, are known locally as seep areas, the largest of which, as determined by field inspection in the fall of 1937, are delineated in figure 12. They comprise most of the bottom land along the North Platte River, isolated areas northwest of Morrill, south of Lyman, north of Mitchell, northwest of Scottsbluff, northeast of Minatare, and south of McGrew, and strips of land of ranging widths along most of the tributaries to the North Platte River.

No data were obtained during this investigation on the quantity of ground water that is evaporated and transpired in Scotts Bluff County from the zone of saturation. In the central Platte Valley, where in some respects the conditions for discharge of this kind are less favorable than in Scotts Bluff County, the quantity of ground water transpired by plants in shallow-water areas was estimated to be 12 inches a year. ${ }^{49}$ In Box Butte County, which lies immediately northeast of Scotts Bluff County, it was concluded that evaporation and transpiration in the shallow-water areas amounts on the average to about 30 inches a year ${ }^{50}$. This figure, however, includes some evaporation and transpiration from the belt of soil moisture. Cady ${ }^{50}$ cites data obtained by the Conservation and Survey Division of the University of Nebraska, which show that 4 feet of water was consumed by arrowhead, wildrice, bulrush, and cattail in Cherry County, Nebr., between July 9, 1937, and September 20,1937 , and that a like quantity was consumed by swamp grasses and tall meadow grasses during the same period, where the water table lay about 3 feet below the land surface.

The water table beneath at least 100 square miles in Scotts Bluff County lies sufficiently close to the land surface to be reached by the roots of most plants. If it is assumed that an average of 18 inches of water is transpired and evaporated each year from the zone of saturation in this area, it may be concluded that the evapo-transpiration losses amount to about 100,000 acre-feet a year.

\section{SPRINAS}

The development of irrigation on the upper terraces north of the North Platte River has caused the water table to rise and the lateral percolation of ground water to increase. As a result springs have appeared, where the topography is favorable at many places along the

\footnotetext{
49 Lugn, A. L., and Wenzel, L. K., Geology and ground-water resources of south-central Nebraska, with special reference to the Platte River Valley between Chapman and Gothenburg: U. S. Geol. Survey WaterSupply Paper 779, p. 151; 1938.

so Cady, R. C., and Ścherer, O. J., Geology and ground-water resources of Box Butte County, Nebr.: U. S. Geol. Survey Water-Supply Paper 969 (in press).
} 
margins of the terraces at the contact of the Brule formation with the overlying terrace gravels. Such springs are situated in the so-called seep areas outlined in figure 12. The source of their flow is, of course, the irrigation water, which is supplied on the terraces north and above them.

Springs occur also south of the North Platte River outside the areas affected by irrigation. On the south side of the river the topography is characterized by a steep north-facing escarpment which marks the southern limit of the lowland area and above which are the High Plains proper. At the foot of these escarpments the Brule formation forms long gradual slopes. Where the Brule is protected by overlying hard beds, however, the escarpment is very steep, as at the Scottsbluff National Monument and along the summits of the buttes west of it, which form the prominent ridge between the Pumpkin Creek Valley and the North Platte Valley. The main ridges have been incised by numerous reentrants that extend backward into the escarpment face. Nearly all the canyons and smaller escarpment salients, which characterize the erosional remnants of the High Plains in southern Scotts Bluff County, contain small springs, many of which issue from the contact between the Brule and the Arikaree. The water from most of them flows only a few hundred feet and then sinks into the alluvium. A few of the springs have been developed for house and stock use, notably those in the vicinity of Carter Canyon and other canyons along the divide extending eastward from Signal Butte. The flow of two springs emanating from the north face of Carter Canyon, in the NE 1/4 sec. 28, T. 21 N., R. $56 \mathrm{~W}$., have been piped to two houses on the south side of the canyon road where the water is used for domestic and stock purposes. Another spring in the same canyon, in the SE 1/4 sec. 22 , T. 21 N., R. $56 \mathrm{~W}$., has been equipped with a pump and is the source of supply for a few farmers who formerly were forced to haul water because the wells in that area failed to produce adequate supplies from the Brule. Three springs on the south side of the promontory separating Carter and Cedar Canyons, in the SE $1 / 4$ sec. 26, T. 21 N., R. 56 W., are reported to flow sufficient water to supply 2,000 sheep, and a spring in the $\mathrm{SW} 1 / 4$ sec. 17, T. $21 \mathrm{~N}$., R. $56 \mathrm{~W}$., at the head of Owl Creek, is reported to be ample for 1,000 cattle. The flow of a spring in the SW1/4 sec. 8, T. 21 N., R. $56 \mathrm{~W}$., has been piped nearly half a mile to a house, now abandoned, at the southwest corner of the same section.

Several springs issue from the north-facing escarpment in the vicinity of Roubadeau Pass. One of the springs, situated near the site of the old Roubadeau blacksmith shop, a landmark on the Oregon Trail, was used by the emigrants travelling westward over the pass.

Several springs occur in the general vicinity of Signal Butte, as in the NE $1 / 4$ of sec. 15, T. 21 N., R. 57 W., and near the Tompsett ranch in the NW $1 / 4$ sec. 11, T. 20 N., R. 57 W. A small dam to impound the water issuing from a spring has been constructed across the floor of one of the short canyons in the NE1 $/ 4$ sec. $11, T .20$ N., R: 54 W. The water thus stored is used for watering stock.

A spring of historical interest issues from near the base of the south side of Scotts Bluff Monument. This spring, called Scotts Spring, is the one to which the mortally ill Scott, for whom the Bluff was named, crawled on his hands and knees just before his death.

The springs that issue along the precipitous face of the escarpments near the heads of canyons and along the margins of Wild Cat Ridge and 
other prominent ridges are supplied by the precipitation on the high upland areas in southern Scotts Bluff County. The Brule formation here appears to be less fractured than elsewhere in the county and the part of the precipitation that reaches the zone of saturation percolates laterally through the overlying formations along the top of the Brule to issue as springs in areas where the top of the Brule is exposed.

\section{SEEPAGE INTO STREAMS AND RLTURN PLOW FROM IRRICATION}

The contour map of the water table (pl. 3) shows that the general direction of movement of ground water in Scotts Bluff County is toward the North Platte River. Much of the ground water is discharged directly from the formations into the river; some of it, however, is intercepted by tributaries, including drainage ditches, and reaches the river indirectly through them. Practically all the ground water that percolates into the streams of the county eventually goes to augment the flow of the North Platte River.

Most of the ground water discharged by the streams in Scotts Bluff County is return flow from irrigation, that is, water that has been added to the zone of saturation by seepage from irrigation canals and irrigated fields. This conclusion is based largely on the great increase in flow of the streams of the county that has taken place since irrigation was begun. Prior to 1911 the aggregate discharge of all the tributaries to the North Platte River from the State line to Bridgeport was less than 25,000 acre-feet a year; since 1927 it has in no year been less than 300,000 acrefeet. (See p. 16.)

The increase in ground water discharge by streams is well illustrated by the flow of Gering drain, which was constructed to prevent the waterlogging of land in Cedar Valley. The discharge of the drain for the first 3 months of each year from 1923 to 1938 , measured just above its confluence with the North Platte River, is plotted in figure 13. During these months the flow of the drain is supphed almost entirely by groundwater percolation. An inspection of figure 13 shows that the discharge of the drain increased each year from 1923 through 1931. In 1923 the discharge was 218 acre-feet; in 1931 it was 6,200 acre-feet. Since 1931 the discharge has fluctuated considerably, but it has not dropped below 2,995 acre-feet. The smaller discharges in 1935 and 1937 were doubtless caused by less seepage to the zone of saturation in the summers of 1934 and 1936 when the quantity of surface water diverted for irrigation was small.

A statistical analysis of the return flow from irrigation is given on pages 692 to 698 of the twenty-second biennial report of the Nebraska Department of Roads and Irrigation. This analysis is based on the discharge of the tributaries to the North Platte River (which is called visible return flow) and does not include the flow that enters the river directly from the formations (invisible return flow). The analysis shows that during the water year ending September 30, 1938, 441,616 acre-fet of water was discharged into the North Platte River by its tributaries between the State line and Bridgeport, and 53,304 acre-feet of water was diverted for irrigation from these tributaries above their confluences with the river. Thus the total visible return flow is computed to be 494,920 acre-feet. During the same period, 363,418 acre-feet of water was diverted for irrigation from the North Platte River between the State 
line and Bridgeport. The figures for visible return flow given in the report are presumably maximum values since some of the flow of the tributaries consists of direct runoff from precipitation. The excess of visible return flow over diversions from the river is more apparent than real, because an unknown but large quantity of irrigation water is diverted from the river in Wyoming and is carried into Scotts Bluff County in the Interstate and Fort Laramie canals.

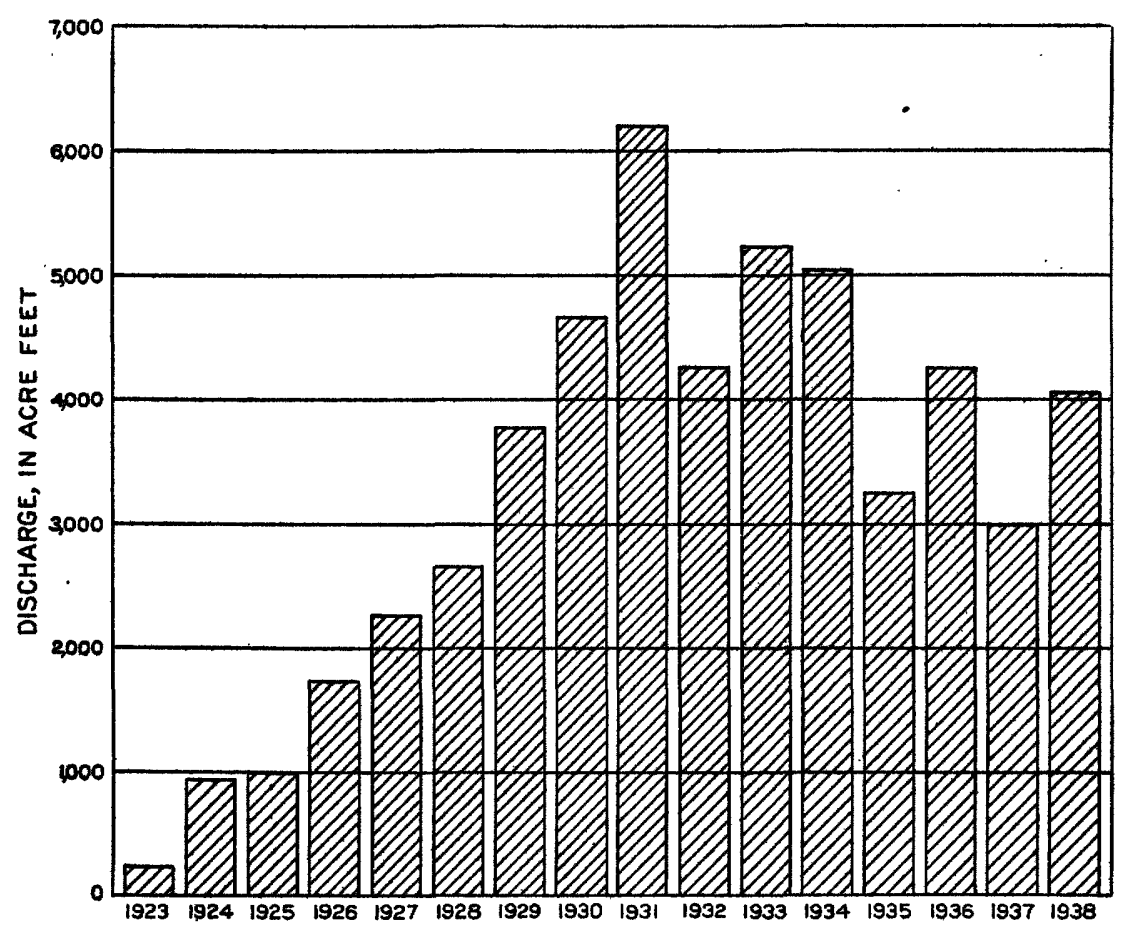

Froura 13.-Discharge of Gering drain for first 3 months of each year from 1923 to 1938.

A study of the return flow in Scotts Bluff County was made in connection with the present investigation. The study was divided into two parts: an analysis of the flow of the North Platte River to determine the gain or loss of flow in selected sections of the stream, and by an analysis of the flow of the tributaries to determine the relation of their flow to ground-water levels.

\section{NORTH PLATTE RIVER}

The discharge of the North Platte River is measured at 3 places in or very near Scotts Bluff County - at the State line, at Mitchell, and at Minatare. For purposes of study the river was accordingly divided into two segments, that between the State line and Mitchell, a stretch of about 13 miles, and that between Mitchell and Minatare, a stretch of 
about 17 miles. All diversions from the river and all inflow to the stream from tributaries in both segments are measured. Between the State line and Mitchell water is diverted from the river by the Gering, Tri-State, Ramshorn, and Enterprise canals and water is discharged into the river by Horse creek, Lane drain, Sheep creek, Toohey spillway, and Dry Spottedtail creek. Between Mitchell and Minatare diversions are made into the Winter Creek, Central, Minatare, Ninemile, and Castle Rock canals, and inflow occurs from Fanning seep, Mitchell Factory waste, Mitchell spillway, Wet Spottedtail Creek, Tub Springs, Scotts Bluff drain No. 1, Scotts Bluff drain No. 2, Winter Creek, Gering drain and Melbeta drain. The net gain or loss in each section was computed by subtracting from the discharge at the gaging station immediately upstream the aggregate quantity of water diverted in the segment, and subtracting the figure so obtained from the difference between the discharge at the gaging station immediately downstream and the aggregate quantity of water discharged by tributaries into the river in the segment. The results of the computations, based on monthly discharges from 1931 to 1938 , are shown graphically by block diagrams on plate 12 .

The total height above the base line of the left side of each block represents the measured discharge of the river at the upstream gaging station in the segment considered, and the total height above the base line of the right side of each block represents the measured discharge at the downstream gaging station in the segment. Thus the direction of slope of the line across the top of the block shows whether a gain or loss of flow occurred that month in the section and the difference in heights of the sides of the block indicates the magnitude, shown by the scale on the sides of the plate, of the gain or loss.

If diversions for irrigation were made in the segment during the month, the left side of the block has been divided into two parts. One part represents the magnitude of the diversions and the other part represents, therefore, the quantity of water that would pass the down stream station if no other gain or loss occurred in the segment. For some months, such as September 1937, one part is negative and is, therefore plotted below the base line. The difference in height of the ends of the diagonal line shows the total computed gain in flow between the two stations (gains occurred in all months in both segments) and the horizontal line projects the part of the flow at the upstream station that should pass the downstream station, were there no gain or loss, to the right side of the block.

The right side of the block is divided into 3 parts. The upper part represents the magnitude of the measured visible pick-up (discharge of the tributaries) in the section, the lower part represents the flow that should pass the downstream station were there no gain or loss in the section, and the middle part represents, therefore, the invisible gain in the segment. A diagonal line is drawn to separate the visible pick-up from the invisible pick-up. Thus two or three triangles are formed at the top of each block, depending on whether water was diverted in the segment, the area of each being proportional to the magnitude of the gain or loss in discharge which it represents. The area of the upper triangle is proportional to the volume of water diverted for irrigation, the area of the middle triangle is proportional to the volume of water discharged by the tributaries into the river (visible pick-up), and the area of the lower triangle is proportional to the volume of water gained or lost in the segment (invisible pick-up or loss). 
The diagrams on plate 12 indicate the general regimen of the North Platte River between the State line and Minatare. They show that in the summer months net losses in flow generally occur between the State line and Mitchell, whereas net gains in flow usually occur in the same months between Mitchell and Minatare. They also show, however, that this difference is due chiefly to the larger quantity of water diverted from the upstream segment because, neglecting the diversions, both segments of the river show gains in flow. The diagrams indicate that the flow in the down stream segment of the river in most months is larger than that in the upstream segment due to the cumulative pick-up of water in the sections.

The bottoms of the diagrams for some months, notably those in summer of 1934, project below the base line. This indicates that the volume of water diverted in the segment was greater than the volume that passed the gaging station at the upper end of the section. During July, August, and September 1934 the water that passed the State line, and more besides, was diverted above Mitchell, and that which passed Mitchell, and more besides, was diverted above Minatare. Obviously, for this situation to be possible, water had to be added to the river in the segments, or the river would, of course, have been dry above Mitchell. The flow, which persisted in the river throughout both segments was made up entirely of visible and invisible pick-up in the segments. The importance of the invisible pick-up during these months is apparent since the diagrams show that the visible pick-up was not sufficient to maintain a flow in the river. The invisible pick-up, which in many months is greater than the visible pick-up, constitutes a large proportion of the total pick-up in both segments of the river.

During the 8-year period from October 1, 1931, to September 30, 1938, the period covered by the analysis, the average annual discharge of the North Platte River at the State line amounted to 475,000 acre-feet and the average annual discharge at Minatare amounted to 497,000 acre-feet. Thus there was an average gain in flow in the 30-mile stretch of the river of 22,000 acre-feet a year. During the same period, an average of 304,000 acre-feet of water was diverted from the river-between the State line and Minatare gaging stations. Thus, had there been no gain or other loss of flow between the two stations, the average annual discharge at Minatare would have been 171,000 acre-feet instead of 497,000 acrefeet. Of the average annual indicated gain of 326,000 acre-feet, 195,000 acre-feet reached the stream through tributaries. The invisible pick-up, therefore, averaged 131,000 acre feet a year. For the water year ending September 30, 1938, it was 195,000 acre-feet. Some of the flow of the tributaries, which is regarded as visible pick-up, is included more than once in the above computations, since it is rediverted downstream and again becomes a source of seepage that may appear in downstream tributaries.

Computations made previously (p. 85) indicate that the ground water percolation through each mile of the Brule formation with an effective creviced thickness of 100 feet under a hydraulic gradient of 50 feet to the mile may amount to about 3,200 acre-feet a year. The percolation into the North Platte River in the 30-mile stretch between the State line and Minatare may, accordingly, be computed to be 193,200 acre-feet a year. This compares with an average annual invisible pick-up of 131,000 acre-feet and a visible pick-up of 195,000 acre-feet in 1938 computed 
from the flow of the rivers, canals, and creeks. Much of the invisible pick-up is, of course, discharged from the Brule into the Pleistocene and Recent sand and gravel and thence into the river. The invisible pick-up computed in this manner from ground-water percolation may normally be expected to exceed that computed from the flow of the streams, because some of the ground water moving in the formations is transpired by plants, is evaporated before it reaches the river, or is evaporated after it reaches the river.

\section{TRIBUTARIES OF THE NORTH PLATTE RIVER}

The second part of the study of return flow made in connection with this investigation relates to the flow of the tributaries of the North Platte River and consists of the following three parts: (1) The monthly aggregate discharge of all tributaries, except Horse Creek, which empty into the river between the State line and Minatare, was computed for the period August 1937 through August 1938 from the records of flow given in the twenty second annual report of the Nebraska Department of Roads and Irrigation; Horse Creek was omitted because most of its drainage basin lies outside Scotts Bluff County. (2) The average monthly water levels in 20 wells affected by seepage of irrigation water in Scotts Bluff County were determined from the average weekly levels (see p. 94). (3) The average water level for each month was plotted against the aggregate discharge of the tributaries for the same month.

The points so plotted did not fall in such a manner that a line could be drawn even roughly among them to show the relation of ground-water levels to the flow of the tributaries. The points that apparently were farthest out of place were mostly those for months in which the precipitation was high. It was concluded therefore that a part of the monthly discharge of the tributaries consisted of surface runoff. A correction was then made for this by subtracting a percentage of the average of the monthly precipitation at Scottsbluff and Mitchell from the monthly discharge of the tributaries. It was found that a fairly good rating curve could be constructed by assuming that the flow of the streams increased 2 acre-feet for each inch of precipitation. The rating curve shown in figure 14 was obtained by applying this correction factor. Two acre-feet of water is equivalent to only 0.005 percent of the precipitation on the drainage basins of the tributaries but is equal to about 13 percent of their aggregate annual discharge.

The curve in figure 14 shows that when the average of the water levels in the wells was 32 feet below the measuring points the monthly discharge of the tributaries was about 11,000 acre-feet and when the average water level was only 25 feet below the measuring points the monthly discharge of the streams reached nearly 28,000 acre-feet. The curve shows also that the aggregate discharge of the streams decreases somewhat more than 3,000 acre-feet for every foot of decline in average water level. The conclusion might be reached, by projecting the curve downward, that the tributaries would'go dry should the average water level decline to about 37 feet below the measuring points. This conclusion cannot be made with assurance, however, because the relation between water levels and stream flow may change considerably, chiefly because of changes in evaporation and transpiration when the water table declines to very low stages. Moreover, the validity of the rating curve shown in the figure is 
ADJUSTED 30-DAY DISCHARGE OF SMALL STREAMS BETWEEN STATE LINE

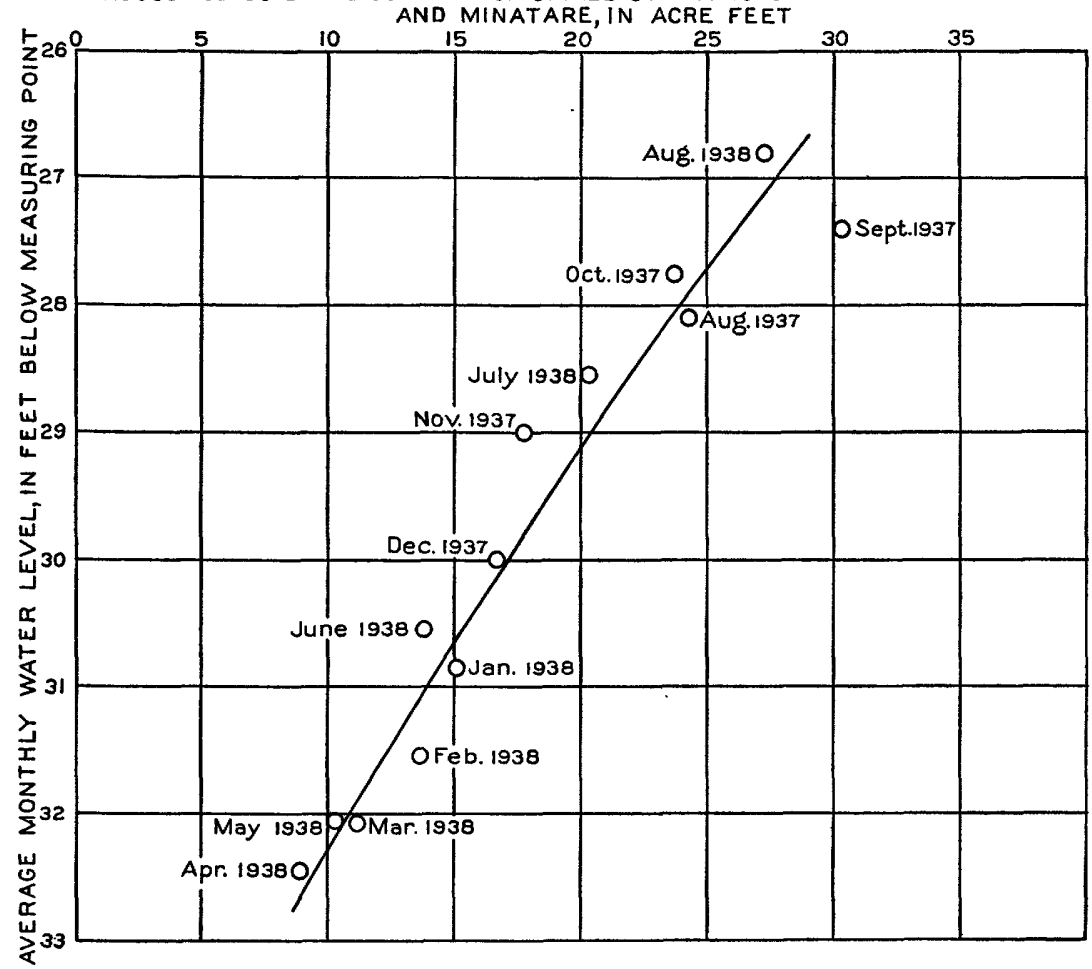

FIGURE 14.-Rating curve showing relation between average water levels in observation wells and discharge of small streams.

not definitely established since it is based on records collected over a period of only 13 months.

\section{SUMMARY}

For the 8-year period ending September 30, 1938, about 64 percent of the water entering Nebraska in the North Platte River was diverted for irrigation upstream from Minatare, yet the flow of the river at Minatare was nearly 5 percent more than that at the State line. If evaporation in the upstream stretches of the stream is neglected, it may be concluded that, of the water that passed downstream at Minatare, nearly 66 percent was gained in Scotts Bluff County, most of it being return flow. The perplexing problem as to the allocation of this part of the flow of the river, both as to priority and quantity, has not as yet been solved.

\section{UNDERFLOW}

The contours of the water table on plate 3 indicate that ground water percolates out of the county in only two areas. There is eastward percolation into Morrill County through the Pleistocene and Recent alluvium underlying the North Platte River and adjacent bottom lands and south- 
ward percolation through the Brule formation from southwestern Scotts Bluff County into Banner County. The underflow through the Pleistocene sand and gravel has been computed to be about 3,000 acre-feet a year. The ground water lost by percolation in the southwestern part of the county probably does not exceed 1,000 acre-feet a year. Thus the ground water discharged from the county by percolation probably does not exceed 4,000 acre-feet a year.

\section{ESTIMATE OF ANNUAL DISCHARGE}

A rough estimate can be made of the quantity of ground water that is discharged yearly in Scotts Bluff County. Estimates made for the annual discharge from wells are: farm wells, 1,300 acre-feet; irrigation wells, 1,246 acre-feet; flowing wells, 400 acre-feet; industrial wells, 2,530 acre-feet; and municipal wells, 2,530 acre-feet;-a total of about 8,000 acre-feet. Discharge through evapo-transpiration from the zone of saturation has been estimated to be about 100,000 acre-feet a year. The gain in flow of the North Platte River between the State line and Minatare averaged 326,000 acre-feet a year for the 8-year period ending September 1938. If 13 percent of this gain is taken to be surface runoff, then the remainder, or about 284,000 acre-feet, represents ground-water discharge. The gaging station at Minatare is situated about 7 miles west of the county line, thus the ground water discharged into the river throughout its entire length in the county is doubtless greater, probably at least 325,000 acre-feet. Estimates made above indicate that about 4,000 acre-feet of water may percolate out of the county through the waterbearing formations. The total discharge of ground water in Scotts Bluff County is thus estimated to be about 437,000 acre-feet a year.

\section{GROUND-WATER RECHARGE}

Ground water in Scotts Bluff County is derived chiefly from seepage of irrigation water, precipitation, and underflow. The amount and frequency of the recharge vary considerably from place to place and from year to year depending particularly on the amount and distribution of the water diverted for irrigation and the precipitation. The hydrographs showing water-level fluctuations in wells (plates 6 to 10) indicate no general persistent upward or downward trend. Records of the discharge of the streams, however, show that their flow during the last few dry years has been somewhat less than it was immediately preceding these years. If it is assumed that the recharge to the underground reservoirs is about equal to the discharge, that is, to about 437,000 acrefeet a year, the annual recharge amounts to a layer of water nearly 1 foot deep over the county. Most of the recharge probably is derived from the seepage of irrigation water.

\section{CHEMICAL CHARACTER OF THE GROUND WATER}

Samples of water from 36 wells in Scotts Bluff County and adjacent areas have been analyzed in the Quality of Water laboratory of the Federal Geological Survey, and two samples of water from the North Platte River also were analyzed. The analyses are presented in the accompanying table. 
All the samples of ground water were taken from wells that obtain their supply from the terrace gravel and alluvium of the North Platte River and its terraces, from the Brule formation, and/or from the Lance formation.

The water in the sand and gravel is uniformly of moderate hardness, averaging about 277 parts per million and ranging from 126 to 345 parts per million. In addition to the calcium and magnesium bicarbonate, which make the water hard, water from the sand and gravel contains widely varying quantities of sodium and potassium, moderately large amounts of sulphate, and small amounts of chloride. These samples show great uniformity, not only in type of water but also in the quantity of the various important constituents with the exception of the sodium and potassium.

Most of the samples from wells in the Brule formation are of a similar type to those from the sand and gravel, that is, they are moderately hard, calcium and magnesium-bicarbonate waters, although, as a whole, they are somewhat less highly mineralized. The hardness of nine of the samples analyzed ranges from 188 to 273 parts per million. The samples from wells $17,172,259,272$, and 303 , however, are soft, having between 44 and 112 parts per million of hardness. These five samples are sodium bicarbonate waters and therefore of a different type from the others.

The bicarbonate in the samples from wells in the Brule is rather uniformly moderate in amount except in the case of the sample from well 259. The amount of sulphate is low to moderate in all samples except that from well 259 . In the rest of the samples it tends to be lower in the softer waters than in the harder. All samples except that from well 259 show small quantities of chloride, less than 70 parts per million. In the sample from well 259 it is 195 parts per million.

The waters from the Lance formation are of a different type from those in the sand and gravel and from most of the samples from the Brule formation. They are very soft sodium bicarbonate waters with low sulfate and chloride content. Their bicarbonate content is about twice that of the waters in the sand and gravel and in the Brule formation.

Two samples of water from the North Platte River were analyzed. One was collected at Henry, the other from the bridge near McGrew. The character of the water is similar to that from wells in the sand and gravel.

The hard and soft waters differ in other respects, and the difference has a bearing upon the uses for which the waters are adaptable. The soft waters from the Lance formation contain a high ratio of sodium salts to calcium and magnesium salts. The average concentration of sulphate in the hard waters is 182 parts per million, whereas in the soft waters it averages only about 7.5 parts per million. These constituents and others have a bearing on the desirability of the water for irrigation. This is shown in the following table, which shows in a general way how the concentration of various salts affects the quality of irrigation water. ${ }^{51}$

st The table is adapted from a more complete one presented by Carl S. Scofield in The salinity of irrigation water: Smithsonian Inst. Ann. Rept., 1935, pp. 275-287. 


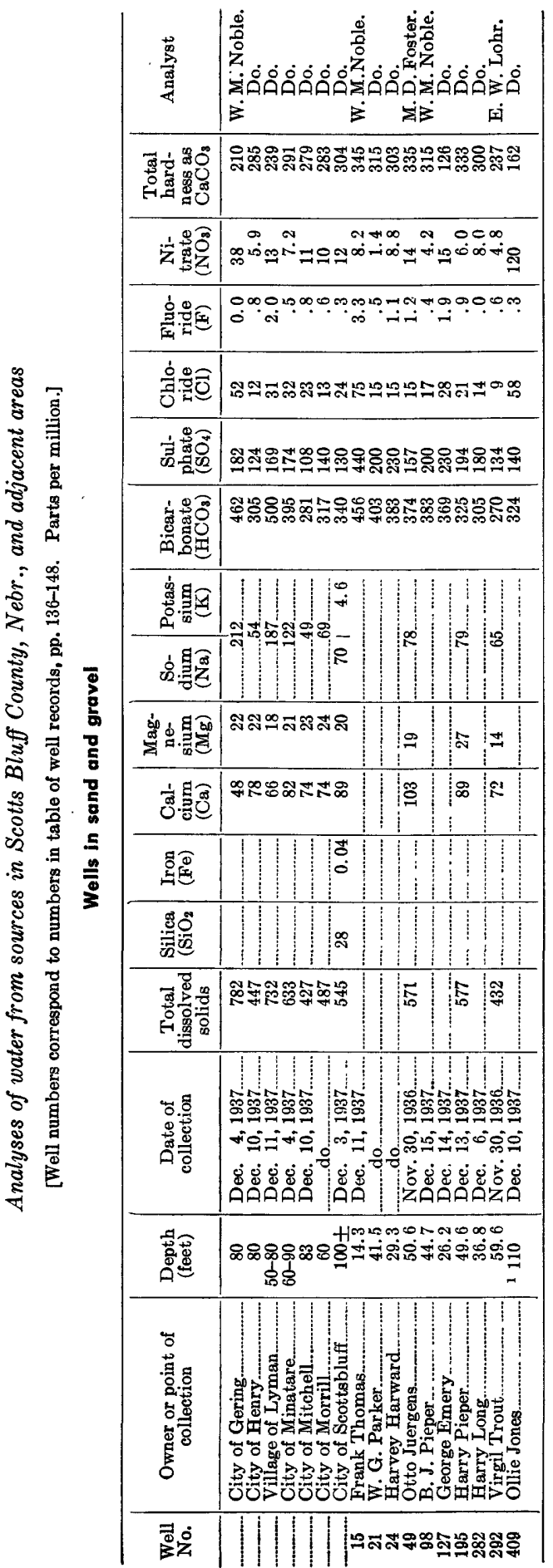

\section{兽}

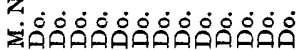
B

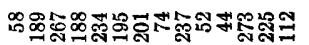

และง

m.

$\circ$

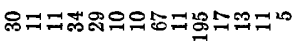

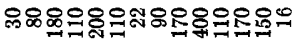

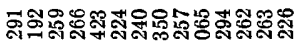
$\rightarrow$

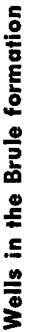

$11+1$

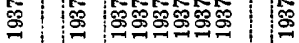

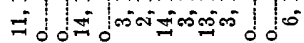
คి

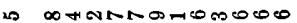

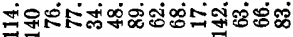

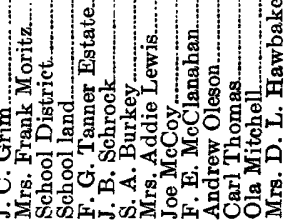

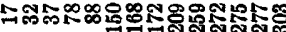


CHEMICAL CHARACTER OF THE GROUND WATER

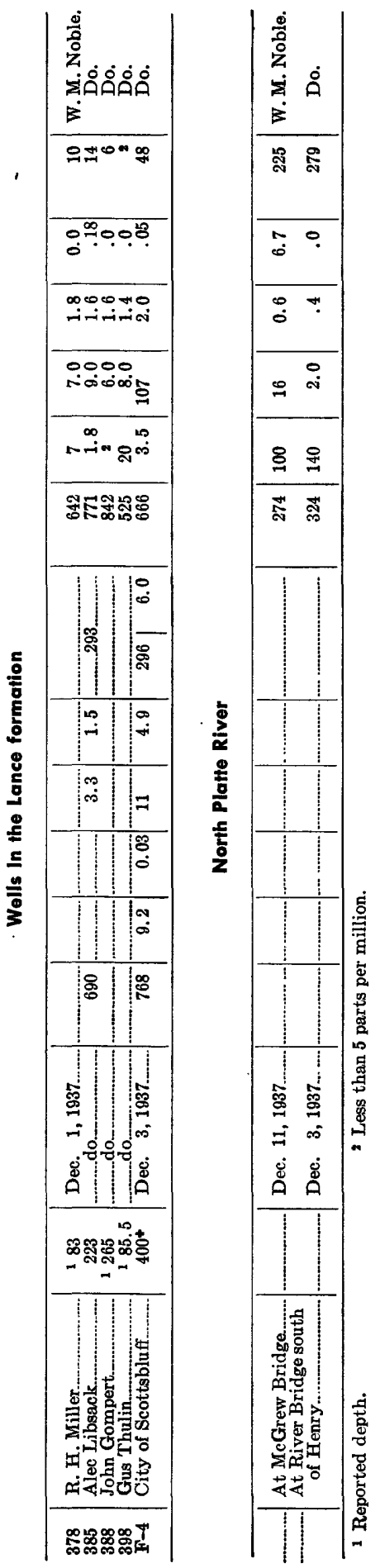


Example of permissible limits adopted for classes of irrigation water

\begin{tabular}{|c|c|c|c|c|}
\hline \multirow{2}{*}{ Classes of water } & \multirow{2}{*}{$\begin{array}{l}\text { Total dissolved } \\
\text { solids (parts } \\
\text { per million) }\end{array}$} & \multirow{2}{*}{$\begin{array}{l}\text { Sodium } \\
\text { (percent) }\end{array}$} & \multicolumn{2}{|c|}{$\begin{array}{c}\text { Concentration } \\
\text { (in milligram equivalents) }\end{array}$} \\
\hline & & & Chlorides & Sulphates \\
\hline $\begin{array}{l}\text { Excellent } \\
\text { Good } \\
\text { Permissible... } \\
\text { Doubtful } \\
\text { Unsuitable }\end{array}$ & $\begin{array}{r}\text { Less than } 175 \\
175-525 \\
525-1,400 \\
1,400-2,100 \\
\text { More than } 2,100\end{array}$ & $\begin{array}{r}\text { Less than } 20 \\
20-40 \\
40-60 \\
60-80 \\
\text { More than } 80\end{array}$ & $\begin{array}{r}\text { Less than } 4 \\
4-7 \\
7-12 \\
12-20 \\
\text { More than } 20\end{array}$ & $\begin{array}{r}\text { Less than } 4 \\
4-7 \\
7-12 \\
12-20 \\
\text { More than } 20\end{array}$ \\
\hline
\end{tabular}

For comparison, the actual values of the constituents given in the above table are appended. One sample is from the city water supply of Scottsbluff, derived from three drilled wells ending in sand and gravel; the other is from an unused well owned by the city of Scottsbluff, which ends in the Lance formation (well F-4). The waters of wells ending in

Actual value of constituents of two samples of irrigation water

\begin{tabular}{|c|c|c|c|c|}
\hline \multirow{2}{*}{ Source of sample } & \multirow{2}{*}{$\begin{array}{l}\text { Total dissolved } \\
\text { solid (parts } \\
\text { per million) }\end{array}$} & \multirow{2}{*}{$\begin{array}{l}\text { Sodium } \\
\text { (percent) }\end{array}$} & \multicolumn{2}{|c|}{$\begin{array}{c}\text { Concentration } \\
\text { (in milligram equivalents) }\end{array}$} \\
\hline & & & Chlorides & Sulphates \\
\hline 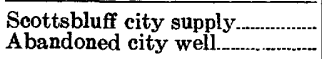 & $\begin{array}{l}548 \\
770\end{array}$ & $\begin{array}{l}34 \\
93\end{array}$ & $\begin{array}{l}0.7 \\
3.0\end{array}$ & $\begin{array}{r}2.7 \\
.7\end{array}$ \\
\hline
\end{tabular}

sand and gravel are very similar to the Scottsbluff city supply, and the waters of Lance wells are similar to well F-4. The formulae for obtaining the milligram equivalents from values in parts per million, and for obtaining the percent sodium are given respectively on pages 7 and 4 of Geological Survey Water-Supply Paper 839.

From a comparison of the analyses of actual water samples in Scotts Bluff County with the table showing permissible limits, it appears that water from the wells in the gravel, most waters from wells in the Brule, and the river water is suitable for irrigation. On the other hand, water from the wells in the Lance formation has a dangerously high concentration of sodium bicarbonate. In many places in the valley bottom of the North Platte and other streams ground water discharges directly into the atmosphere by evaporation and transpiration. In these places the precipitation of salts from the ground water has caused such concentrations of alkali that the land has been withdrawn from agricultural production, and some of it is even unfit for grazing. The acreage of alkali land is considerable, but in the higher lands where the water table lies at greater depth below the land surface the danger from accumulating salts does not seem to be great.

If children whose teeth are in the formative stage drink water containing more than 1 part per million of fluoride the tooth enamel is likely to be defective. This defect is called mottled enamel. The greater the concentration of fluoride the more widespread and acute will be the mottling. The waters from wells in the Brule formation contain on the average only 0.5 part per million of fluoride, and the concentration ranges from 0.0 to 0.9 with the exception of sample 259 , which has 2.2 parts. It is significant that the wells in the Brule that yield soft water, as discussed above, have the larger amounts of fluoride. The harder waters, characteristic of most of the Brule wells, have considerably less than $\mathbf{0 . 5}$ 
part per million of fluoride. The fluoride content of the waters from wells in sand and gravel averages 0.86 , but is variable, ranging from 0.0 to 3.3 parts per million. The waters from wells in the Lance formation are uniformly high in fluoride, averaging 1.78 parts per million, and ranging from 1.4 to 2.0 parts per million. The analyses indicate that fluoride may or may not be present in harmful amounts in waters in the Brule formation and in the sand and gravel, but that it is almost certain to be present in harmful amounts in waters from the Lance formation.

\section{LOGS OF TEST HOLES}

The logs of test holes that have not been presented in the text for some specific purpose appear in the following tables. The test holes were drilled during the summer and early in the fall of 1937 by Howard Haworth and Robert Lawrence of the Conservation and Survey Division, University of Nebraska. Samples were systematically taken and described during the drilling operations.

The location of the test holes is indicated on plate 2 .

Test hole $1^{1}$, in $S W 1 / 4 S W 1 / 4$ sec. $27, T$. $23 N$., R. 56 W., east side of road about 200 yards north of river bridge

\begin{tabular}{|c|c|c|}
\hline & $\begin{array}{c}\text { Thick- } \\
\text { ness } \\
\text { (feet) }\end{array}$ & $\begin{array}{l}\text { Depth } \\
\text { (feet) }\end{array}$ \\
\hline $\begin{array}{l}\text { Top soil and sand. } \\
\text { Gravel, mostly medium to coarse, water-worn Brule, compact, with many boulders, }\end{array}$ & $21 / 2$ & $21 / 2$ \\
\hline
\end{tabular}

1 For data on test holes 2-7 refer as follows:

Test hole 2, see p. 63 .

Test hole 3, see p. 63.

Test hole 5, see p. 63.

Test hole 4, see p. 63 .

Test hole 6, see p. 64 .

Test hole 7, see p. 56 .

Test hole $8^{1}$ in SW1/4NW1/4 sec. 14, T. 23 N., R. 57 W., 0.4 mile north of United States Highway No. 26, first section line east of Morrill

\begin{tabular}{|c|c|c|}
\hline & $\begin{array}{c}\text { Thick- } \\
\text { ness } \\
\text { (feet) }\end{array}$ & $\begin{array}{l}\text { Depth } \\
\text { (feet) }\end{array}$ \\
\hline $\begin{array}{l}\text { Sand. } \\
\text { Sand, coarse, some fine gravel... }\end{array}$ & \multirow{3}{*}{$\begin{array}{l}27 \\
83 \\
66 \\
11 \\
13\end{array}$} & \multirow{3}{*}{$\begin{array}{r}27 \\
110 \\
176 \\
187 \\
\mathbf{2 0 0}\end{array}$} \\
\hline Sand, fine & & \\
\hline $\begin{array}{l}\text { Vravel, twe, and sand unable to get sample. Required } \theta \text { hours to drill through; not sand } \\
\text { or gravel. }\end{array}$ & & \\
\hline
\end{tabular}

1 For data on test hole 9 , see page 64 .

Test hole 10, in SE1/4SE1/4 sec. 2, T. 23 N., R. 57 W., 4 miles northeast of Morrill, · 0.13 mile north of section corner, west side of road

\begin{tabular}{|c|c|c|}
\hline & $\begin{array}{c}\text { Thick- } \\
\text { ness } \\
\text { (feet) }\end{array}$ & $\begin{array}{c}\text { Depth } \\
\text { (feet) }\end{array}$ \\
\hline $\begin{array}{l}\text { Sand, fine } \\
\text { Gravel, mostly coarse, and boulders. } \\
\text { Sand, clayey... }\end{array}$ & $\begin{array}{l}10 \\
88 \\
16\end{array}$ & $\begin{array}{r}10 \\
98 \\
114\end{array}$ \\
\hline
\end{tabular}


Test hole 11, in SE1/4SW1/4 sec. 14, T.23 N., R. 56 W., 0.5 mile east of section corner on north side of road

\begin{tabular}{|c|c|c|}
\hline & $\begin{array}{c}\text { Thick- } \\
\text { ness } \\
\text { (feet) }\end{array}$ & $\begin{array}{l}\text { Depth } \\
\text { (feet) }\end{array}$ \\
\hline $\begin{array}{l}\text { Sand, fine. } \\
\text { Gravel, mostly coarse with many large boulders }\end{array}$ & \multirow{2}{*}{$\begin{array}{l}13 \\
65 \\
10 \\
12\end{array}$} & \multirow{2}{*}{$\begin{array}{r}13 \\
78 \\
88 \\
100\end{array}$} \\
\hline Clay.... & & \\
\hline
\end{tabular}

Test hole 121, in NW1/4 sec. 6, T. $23 \mathrm{~N} .$, R. $55 \mathrm{~W} ., 0.75$ mile north of section corner, 0.25 mile south of county line, east side of road, 7 miles northeast of Mitchell

\begin{tabular}{|c|c|c|}
\hline & $\begin{array}{c}\text { Thick- } \\
\text { ness } \\
\text { (feet) }\end{array}$ & $\begin{array}{l}\text { Depth } \\
\text { (feet) }\end{array}$ \\
\hline $\begin{array}{l}\text { Fine sand, reworked Brule } \\
\text { Sand with a little gravel. }\end{array}$ & \multirow{2}{*}{$\begin{array}{r}6 \\
22 \\
5 \\
27\end{array}$} & \multirow{2}{*}{$\begin{array}{r}6 \\
28 \\
33 \\
60\end{array}$} \\
\hline $\begin{array}{l}\text { Gravel. } \\
\text { Brule }\end{array}$ & & \\
\hline
\end{tabular}

1 For data on test holes 13-15 refer as follows:

Test hole 13, see p. 64 .

Test hole 14, see p. 64 .

Test hole 15, see p. 65 .

Test hole 16, in NW1/4SW1/4 sec. 28, T. 23 N., R. 54W., 0.4 mile north of corner, east side of road, south edge of bridge over irrigation canal

\begin{tabular}{|c|c|c|}
\hline & $\begin{array}{c}\text { Thick- } \\
\text { ness } \\
\text { (feet) }\end{array}$ & $\underset{\text { (feet) }}{\text { Depth }}$ \\
\hline $\begin{array}{l}\text { Sand, fine } \\
\text { Brule. }\end{array}$ & $\begin{array}{r}7 \\
13\end{array}$ & $\begin{array}{r}7 \\
20\end{array}$ \\
\hline
\end{tabular}

Test hole $17^{1}$, in SE1/4NE1/4 sec. $21, T .23 N ., R .54 W$. , south edge of irrigation ditch west side of road, just north of half-mile road

\begin{tabular}{l|l|r|r}
\hline Sand, fine. & $\begin{array}{c}\text { Thick- } \\
\text { ness } \\
\text { (feet) }\end{array}$ & $\begin{array}{r}\text { Depth } \\
\text { (feet) }\end{array}$ \\
\hline \\
\hline
\end{tabular}

1 For data on test hole 18 , see p. 65.

Test hole 19 , in NW1/4SW1/4 sec. $2, T .21 N ., R .55 W ., 0.19$ mile east of section corner, south side of road, 0.5 mile west of Gering on State Highway 86

\begin{tabular}{|c|c|c|}
\hline & $\begin{array}{c}\text { Thick- } \\
\text { ness } \\
\text { (feet) }\end{array}$ & $\underset{\text { (feet) }}{\text { Depth }}$ \\
\hline $\begin{array}{l}\text { Fill, fine pinkish sand, some clay cuts in small slabs } \\
\text { Clayey sand, green........ }\end{array}$ & \multirow{4}{*}{$\begin{array}{r}33 \\
3 \\
4 \\
10 \\
33\end{array}$} & \multirow{4}{*}{$\begin{array}{l}33 \\
36 \\
40 \\
50 \\
83\end{array}$} \\
\hline Clay, green. & & \\
\hline Clay, green, with buff gray clay & & \\
\hline Clay, gray, with some green streaks and hard layers. & & \\
\hline
\end{tabular}


Test hole 20, in SW1/4SW1/4 sec. 15, T. 21 N., R. 55 W., 0.12 mile north of section corner, east side of road

Sand, fine

Clayey sand, fine

Sand, fine, less clay than above

Gravel of water-worn Brule pebbles, gray sandstone, and chert

Clay, brownish, Brule.

\begin{tabular}{|r|r}
$\begin{array}{c}\text { Thick- } \\
\text { ness } \\
\text { (feet) }\end{array}$ & $\begin{array}{c}\text { Depth } \\
\text { (feet) }\end{array}$ \\
\hline & \\
7 & 7 \\
15 & 22 \\
22 & 37 \\
3 & 40 \\
43 & 83
\end{tabular}

Test hole 211 , in $S W 1 / 4 S W 1 / 4$ sec. $21, T .21 N ., R .55 W ., 0.2$ mile north of corner, 50 yards south of railway crossing, on east side of road

Sand, fine.

Reworked Brule and sand

Sand, fine, with pebbles of Brule

Sandy clay, buff, cuts in chips; almost gray from 51 feet, with a few green streaks

\begin{tabular}{|r|r}
$\begin{array}{c}\text { Thick- } \\
\text { ness } \\
\text { (feet) }\end{array}$ & $\begin{array}{c}\text { Depth } \\
\text { (feet) }\end{array}$ \\
\hline & \\
& \\
20 & 20 \\
16 & 36 \\
8 & 44 \\
19 & 63 \\
\end{tabular}

1 For data on test hole 22, see p. 65.

Test hole 23, in NE1/4NE1/4 sec. 26, T. $23 N$., R. 53 W., 0.3 mile west of section corner, south side of road north of farm house

Sand, fine, a few rocks upper few feet.

Brule, reworked with some gray sandstone pieces

Brule.

\begin{tabular}{|r|r}
$\begin{array}{c}\text { Thick- } \\
\text { ness } \\
\text { (feet) }\end{array}$ & $\begin{array}{r}\text { Depth } \\
\text { (feet) }\end{array}$ \\
\hline & \\
13 & 13 \\
6 & 19 \\
18 & 37 \\
\hline
\end{tabular}

Test hole 24, in SE1 $14 N E 1 / 4$ sec. 10, T. $22 N$., R. 53 W., 50 yards north of half-mile road to east, on west edge of road

\begin{tabular}{l|r|r}
\hline & $\begin{array}{c}\text { Thick- } \\
\text { ness } \\
\text { (feet) }\end{array}$ & $\begin{array}{r}\text { Depth } \\
\text { (feet) }\end{array}$ \\
\hline Road fill and fine sand. & $\begin{array}{r}9 \\
11\end{array}$ & $\begin{array}{r}9 \\
20 \\
40\end{array}$ \\
Sand, coarse with some fine gravel lower few feet, some Brule... & 20 & \\
Brule, undisturbed.
\end{tabular}

Test hole 25, in NW1/4NW1/4 sec. 22, T. $22 N ., R .53 W$. , south side of road in ditch, center of valley

\begin{tabular}{|c|c|c|}
\hline & $\begin{array}{c}\text { Thick- } \\
\text { ness } \\
\text { (feet) }\end{array}$ & $\begin{array}{l}\text { Depth } \\
\text { (feet) }\end{array}$ \\
\hline 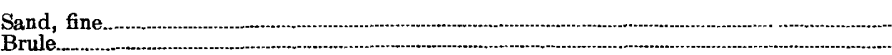 & $\begin{array}{r}11 \\
. \quad 3\end{array}$ & $\begin{array}{l}11 \\
14\end{array}$ \\
\hline
\end{tabular}


Test hole $26^{1}$, in $N W 1 / 4 N W 1 / 4$ sec. 32, T. 22 N., R. 53 W., south edge of road just west of United States Highway No. 26

\begin{tabular}{|c|c|c|}
\hline . & $\begin{array}{c}\text { Thick- } \\
\text { ness } \\
\text { (feet) }\end{array}$ & $\begin{array}{l}\text { Depth } \\
\text { (feet) }\end{array}$ \\
\hline $\begin{array}{l}\text { Top soil. } \\
\text { Clayey sand, yellow } \\
\text { Gravel. } \\
\text { Gravel, but much finer than above. } \\
\text { Gravel, coarse } \\
\text { Gravel, many boulders, very difficult drilling }\end{array}$ & $\begin{array}{r}4 \\
8 \\
66 \\
34 \\
16 \\
82\end{array}$ & $\begin{array}{r}4 \\
12 \\
78 \\
112 \\
128 \\
210\end{array}$ \\
\hline
\end{tabular}

1 For data on test hole 27 see p. 65.

Test hole 28, in NW1/4SW1/4 sec. 18, T. 21 N., R. 53 W., just east of road, about 75 feet north of bridge

Sand and gravel

Gravel.

Brule...

\begin{tabular}{|r|r}
$\begin{array}{c}\text { Thick- } \\
\text { ness } \\
\text { (feet) }\end{array}$ & $\begin{array}{r}\text { Depth } \\
\text { (feet) }\end{array}$ \\
\hline & \\
16 & 16 \\
38 & 54 \\
23 & 77 \\
\hline
\end{tabular}

Test hole 29, in SW1/4SE1/4 sec. 24, T. 21 N., R. 54 W., north side of road approximately 0.45 mile west of section corner

Top soil and fine sand, some clay in sand

Clayey sand, sticky.

Reworked and water-worn Brule.

Sand and gravel with much water-worn Brule

Brule.

\begin{tabular}{|r|r}
$\begin{array}{c}\text { Thick- } \\
\text { ness } \\
\text { (feet) }\end{array}$ & $\begin{array}{r}\text { Depth } \\
\text { (feet) }\end{array}$ \\
\hline & \\
16 & 16 \\
5 & 21 \\
5 & 26 \\
9 & 35 \\
28 & 63 \\
\hline
\end{tabular}

Test hole 30 , in SE1/4SE1/4 sec. $34, T .21 N ., R .54 W .$, just west of road to the south

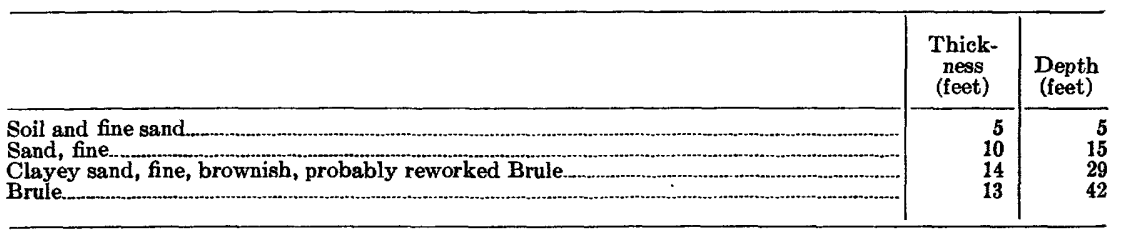

Test hole $31^{1}$, in $S W 1 / 4 S W 1 / 4$ sec. 8, T. $21 N ., R .52 W$. , east side of road, 50 feet north of bridge at road intersection

\begin{tabular}{|c|c|c|}
\hline & $\begin{array}{c}\text { Thick- } \\
\text { ness } \\
\text { (feet) }\end{array}$ & $\begin{array}{c}\text { Depth } \\
\text { (feet) }\end{array}$ \\
\hline Fill & 4 & \\
\hline $\begin{array}{l}\text { Clayey sand. } \\
\text { Sand and gravel, compact tough drilling. }\end{array}$ & $\begin{array}{r}5 \\
73\end{array}$ & 82 \\
\hline Sand and gravel & 19 & 117 \\
\hline $\begin{array}{l}\text { Gravel, boulders } \\
\text { Brule. }\end{array}$ & $\begin{array}{l}39 \\
12\end{array}$ & $\begin{array}{l}156 \\
168\end{array}$ \\
\hline
\end{tabular}

I For data on test hole 32 , see p. 65. 
Test hole 33, in SE corner SW1/4 sec. 36, T. 21 N., R. 53 W., 0.25 mile south of McGrew

\begin{tabular}{|c|c|c|}
\hline & $\begin{array}{c}\text { Thick- } \\
\text { ness } \\
\text { (feet) }\end{array}$ & $\underset{\text { (feet) }}{\text { Depth }}$ \\
\hline $\begin{array}{l}\text { Soil and silty sand. } \\
\text { Sandy clay, sticky. } \\
\text { Gravel. } \\
\text { Brule. }\end{array}$ & $\begin{array}{r}7 \\
\mathbf{5} \\
\mathbf{2 0} \\
\mathbf{5 2}\end{array}$ & $\begin{array}{r}7 \\
12 \\
32 \\
84\end{array}$ \\
\hline
\end{tabular}

Test hole $34^{1}$, in SW1 14 SE1/4 sec. 17, T. 20 N., R. $53 \mathrm{~W} ., 0.45$ mile west of section corner on north edge of road

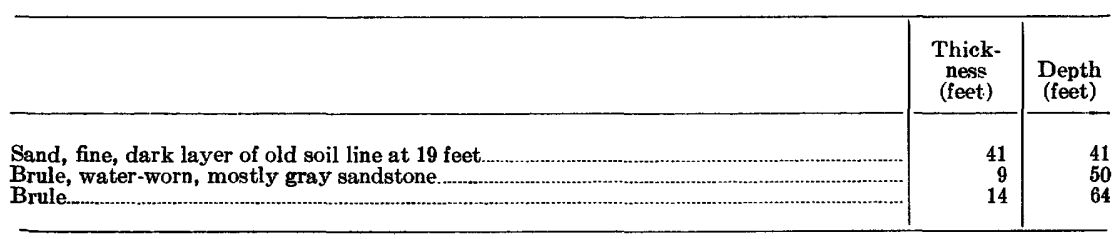

1 For data on test hole 35, see p. 66. 


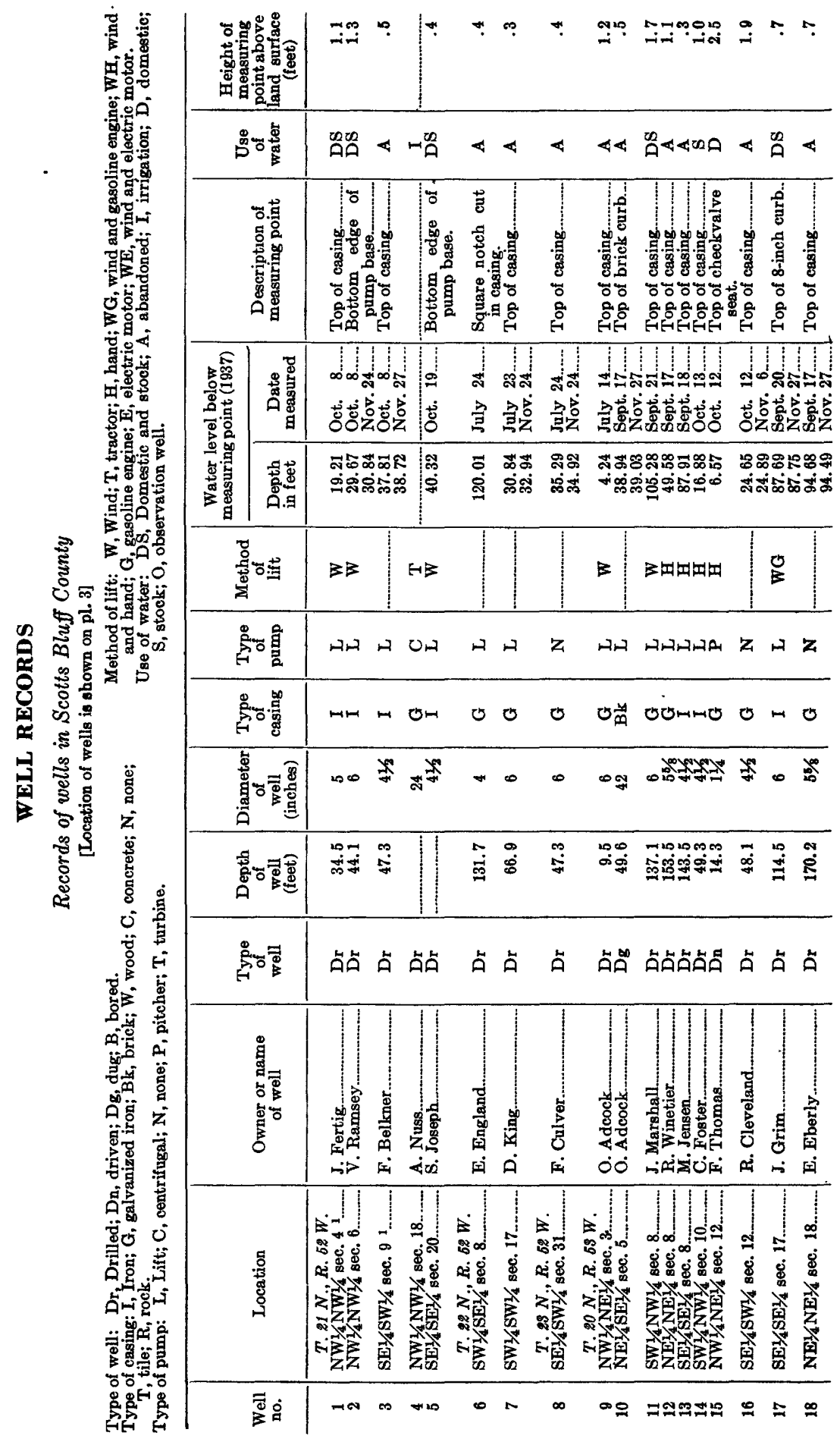


어

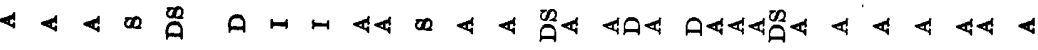

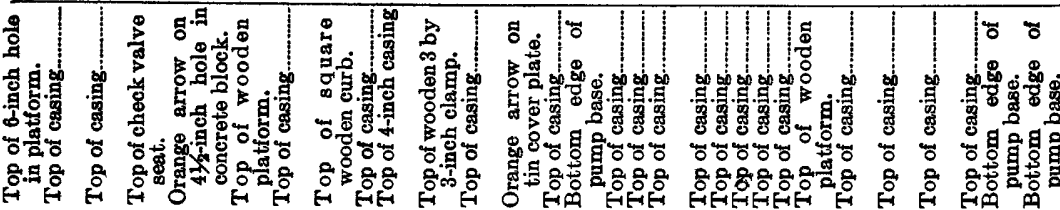

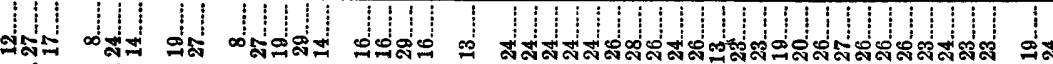

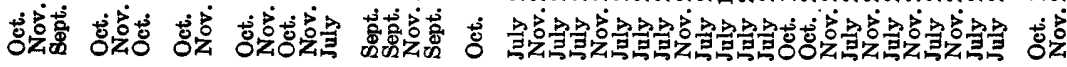

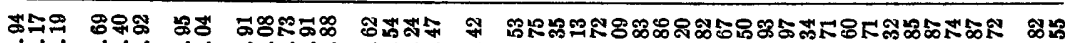

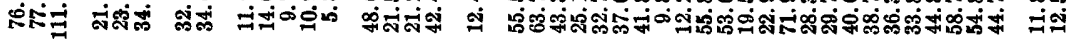

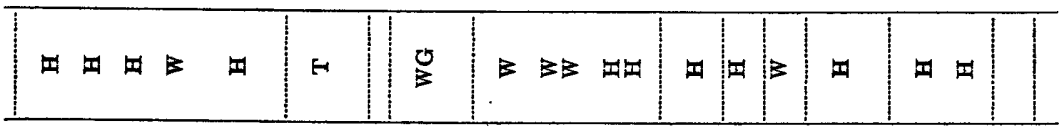

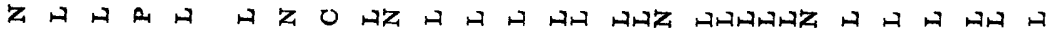

ర

。

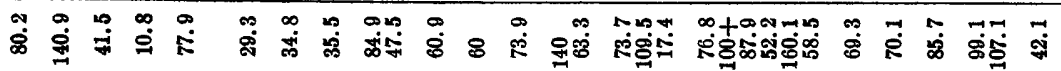

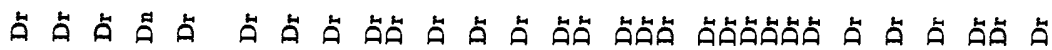

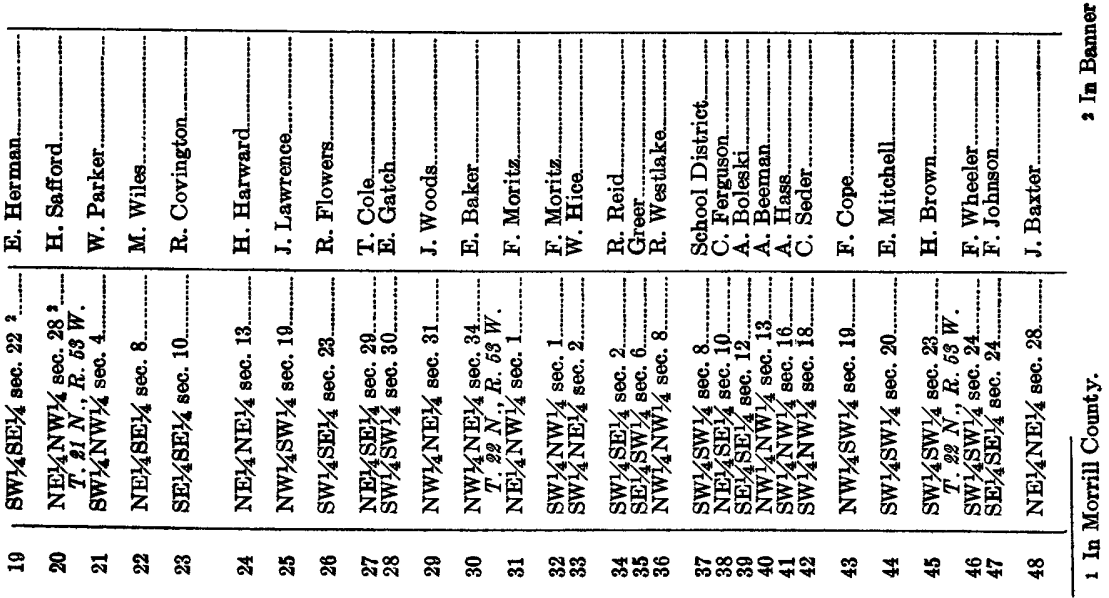




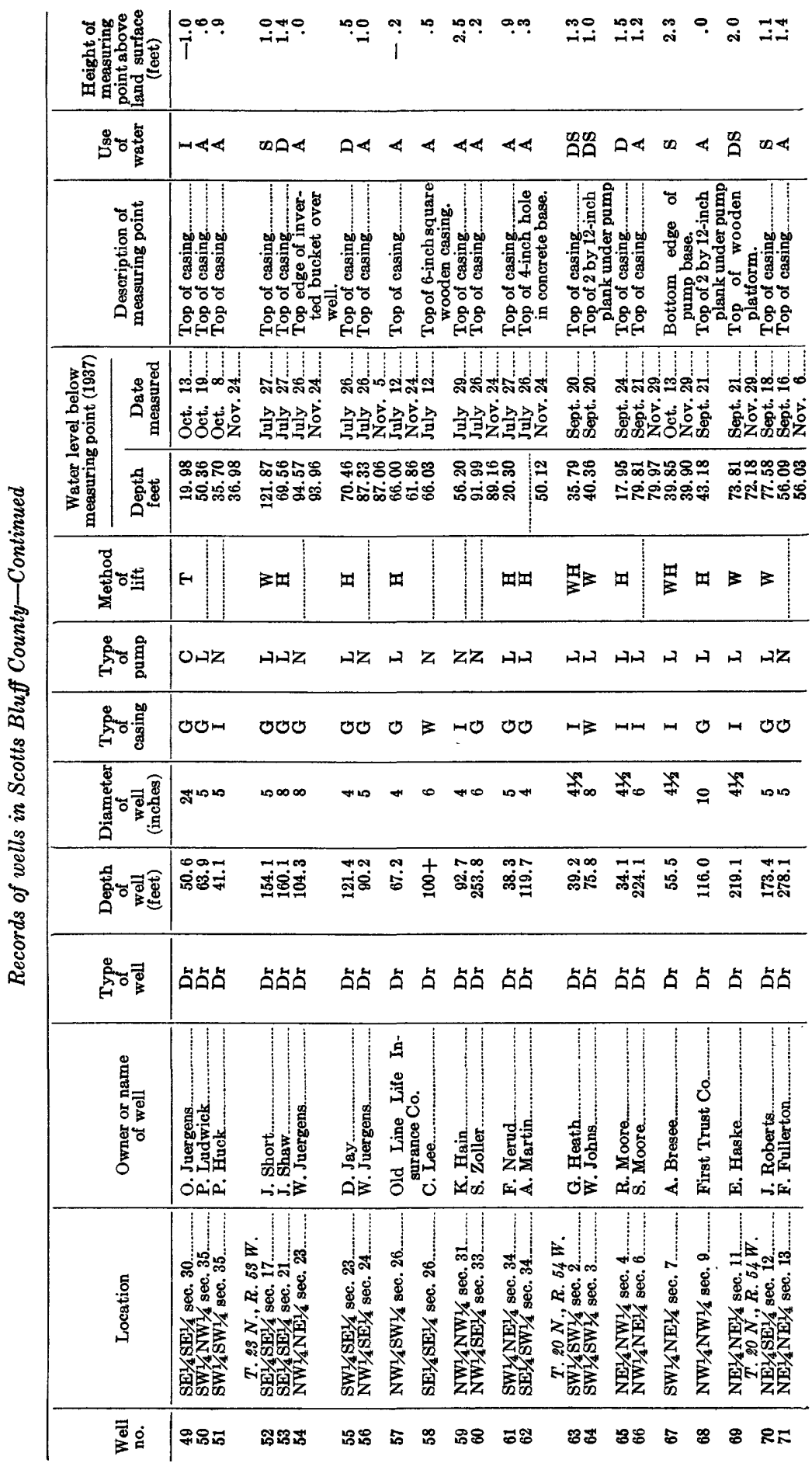




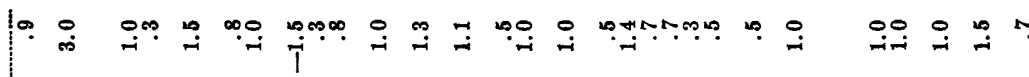

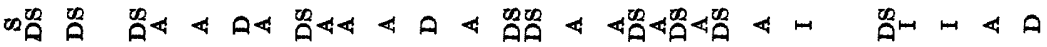

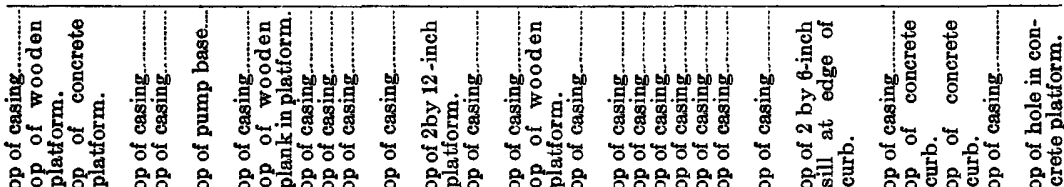

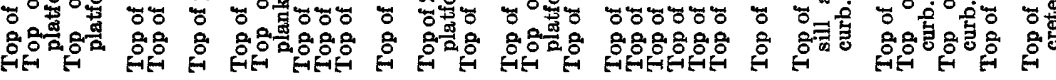

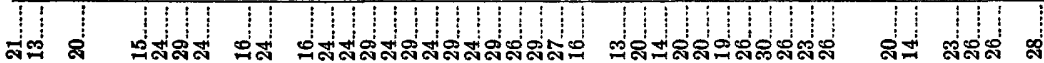

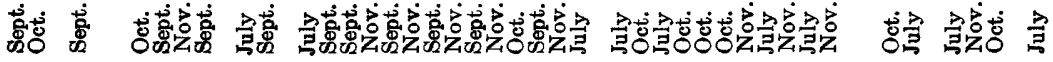

0ீ

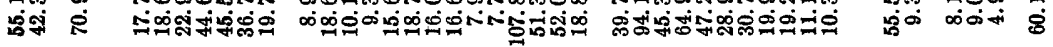

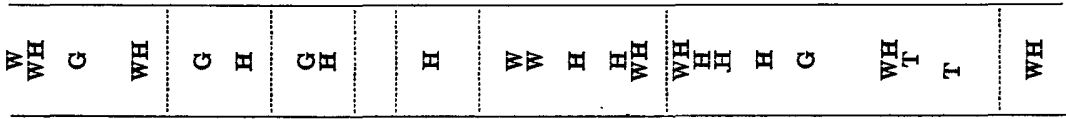

Мル

भIM H MO

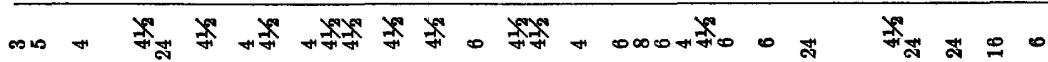

నุำ

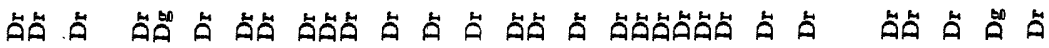

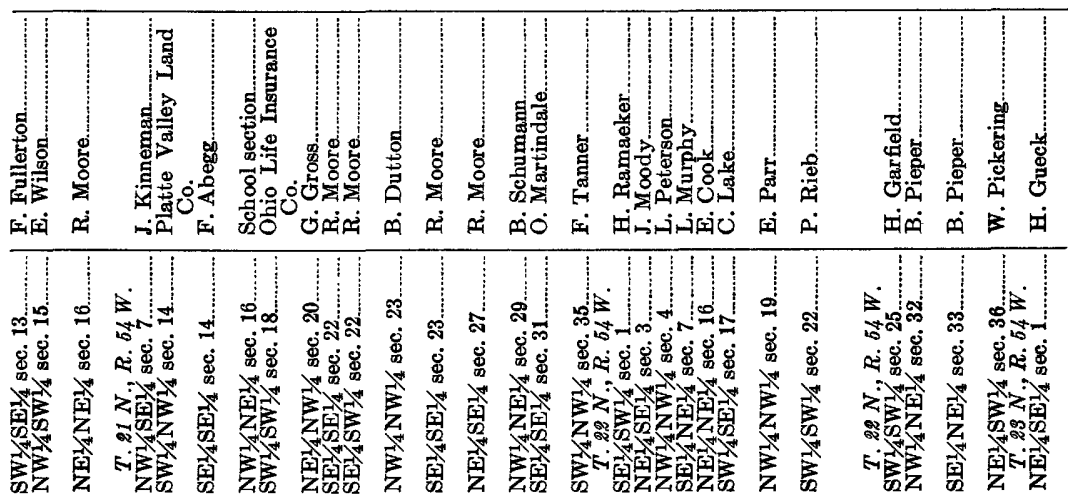

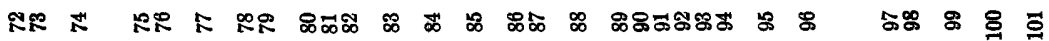




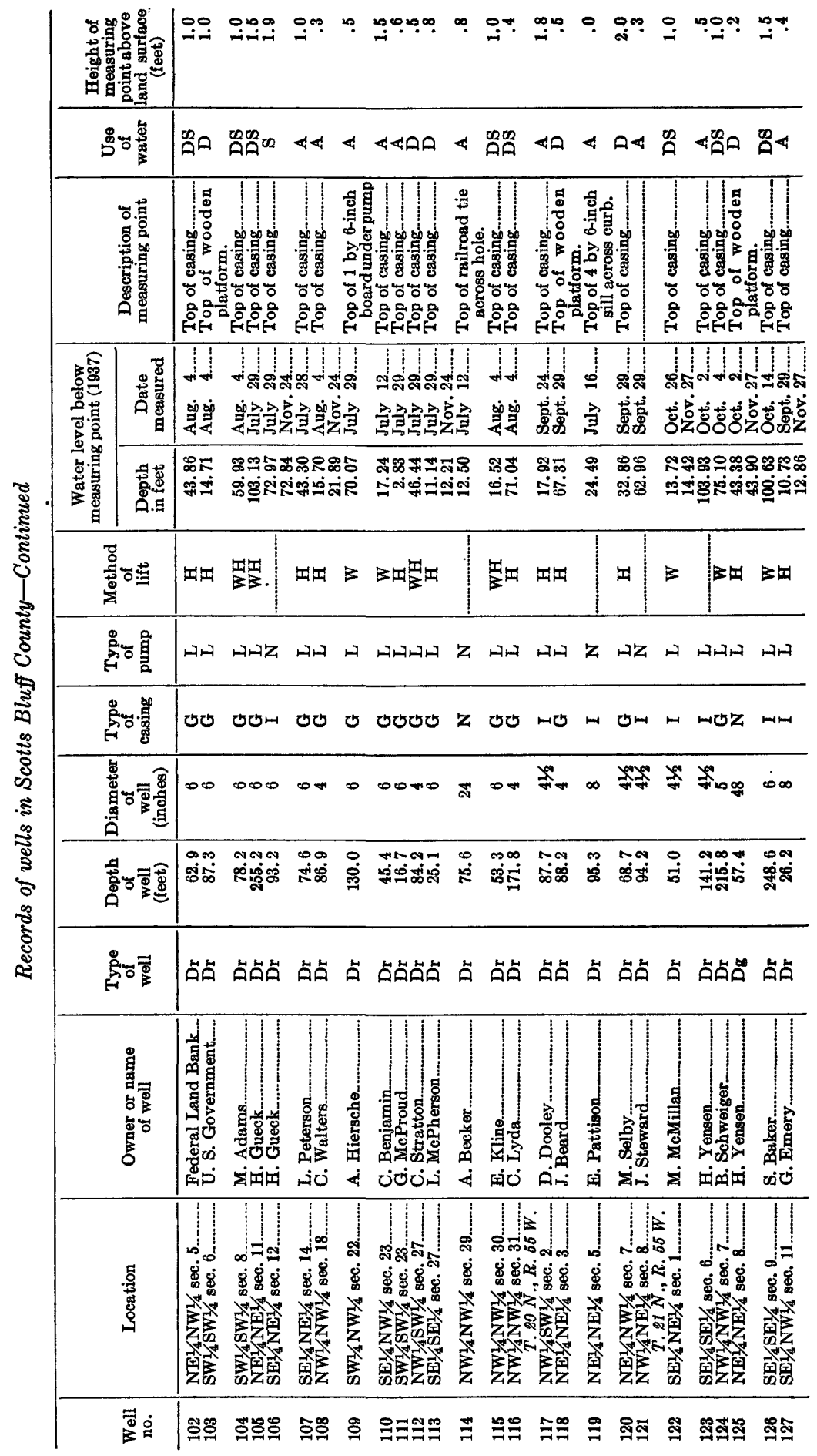




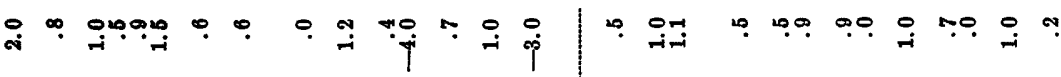

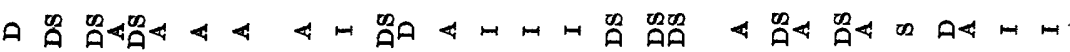

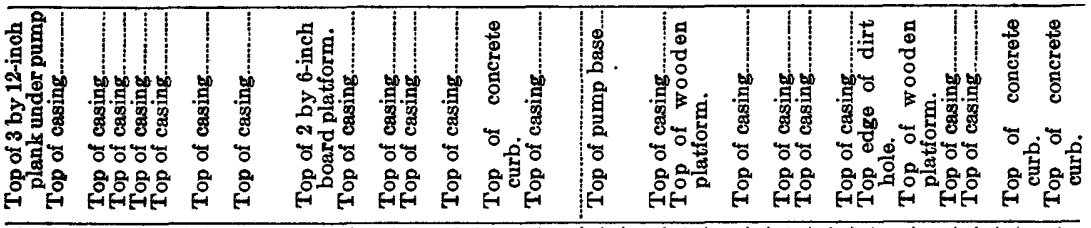

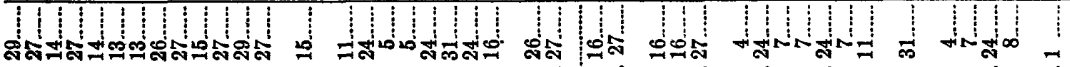

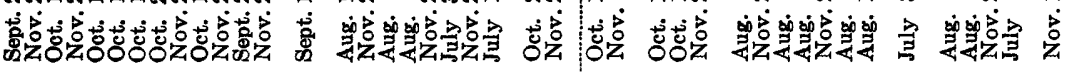

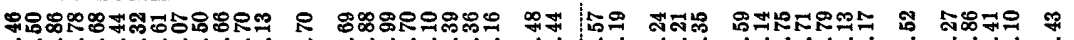

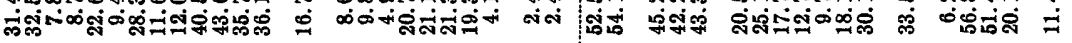

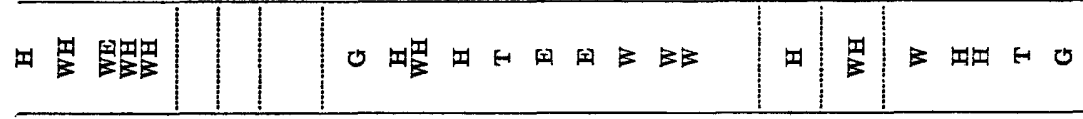

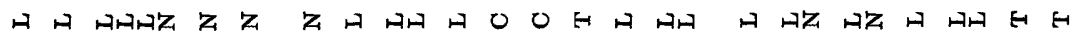

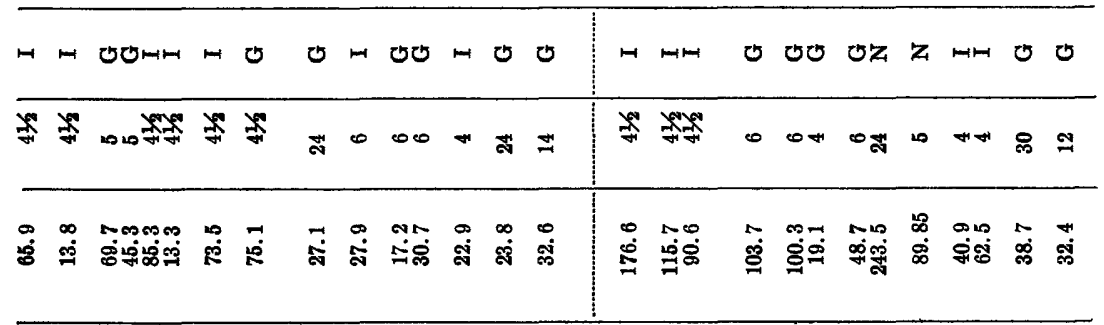

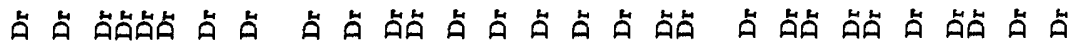

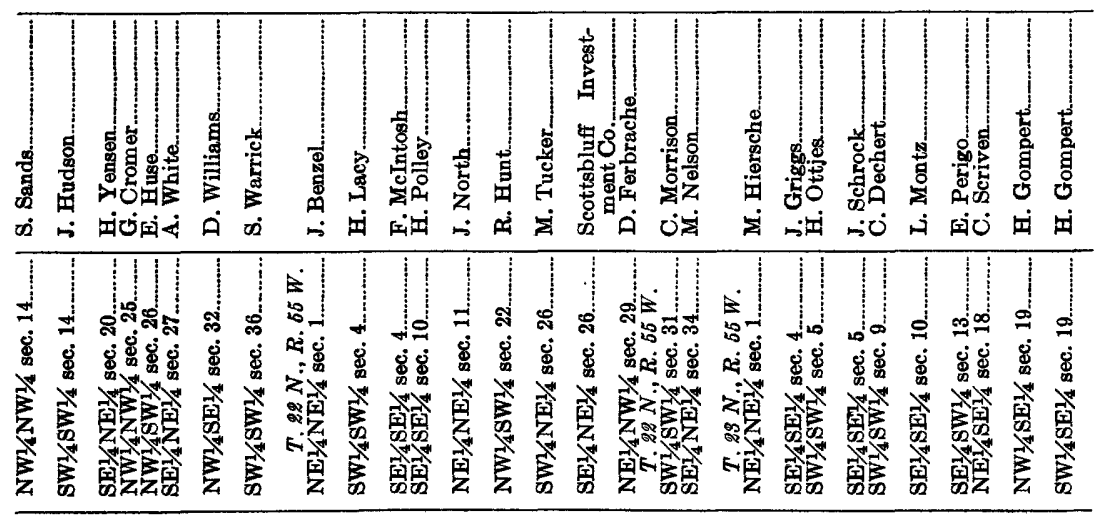

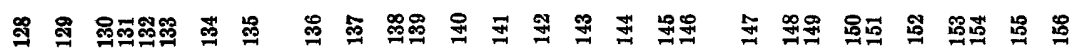




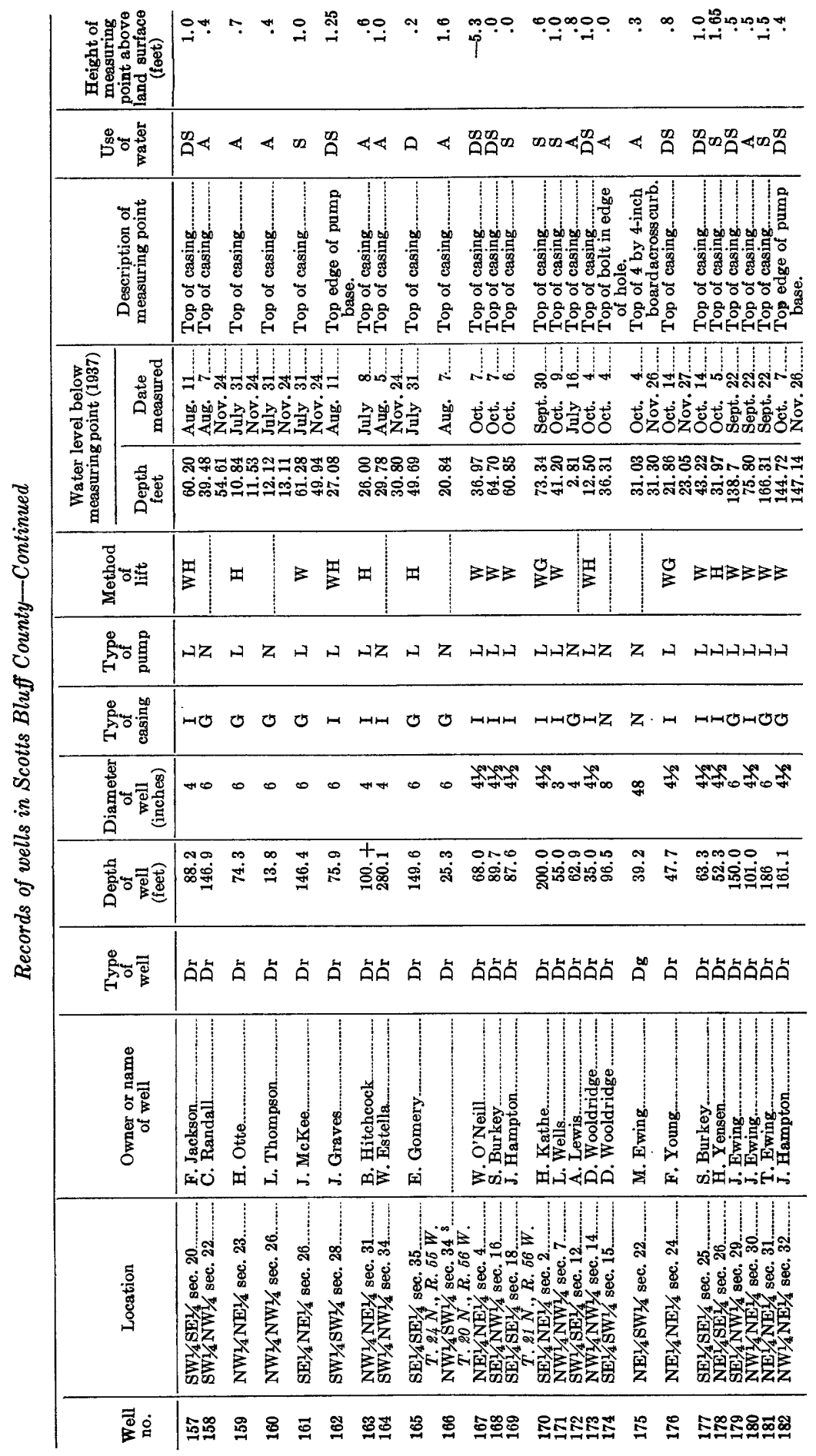




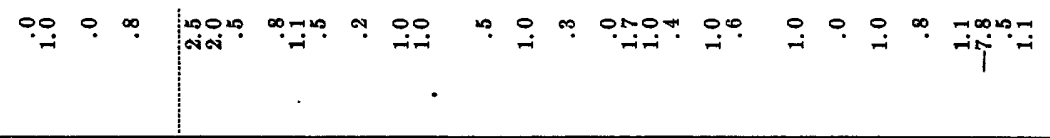

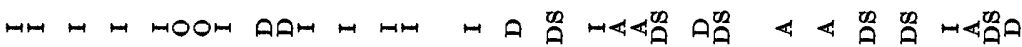

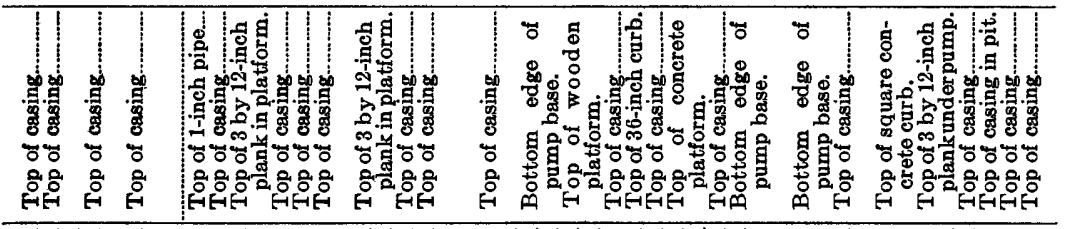

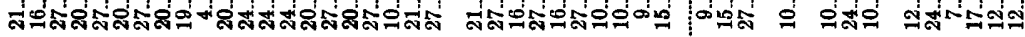

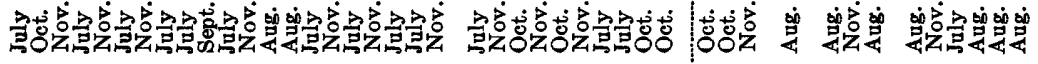

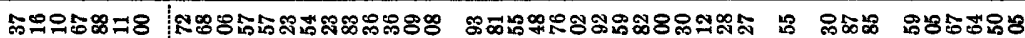

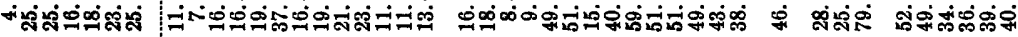

HE 国

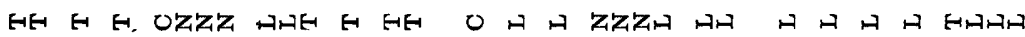

ठ 0 ठ

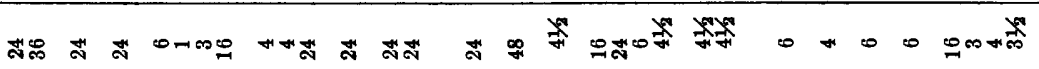

చீ.

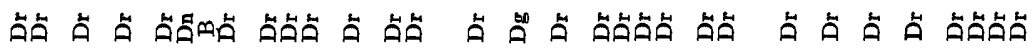
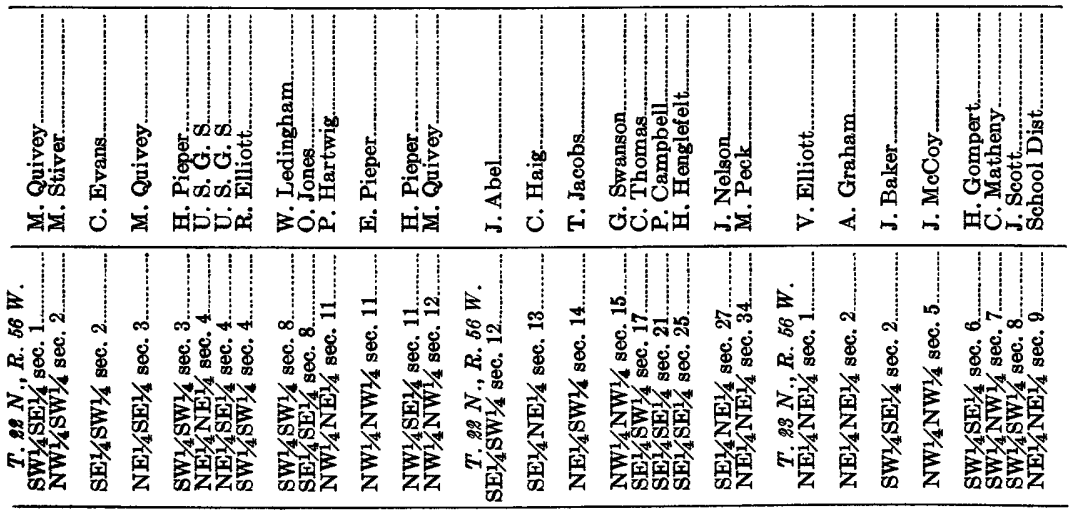

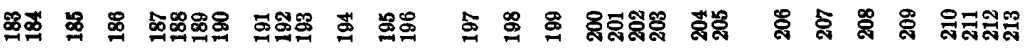




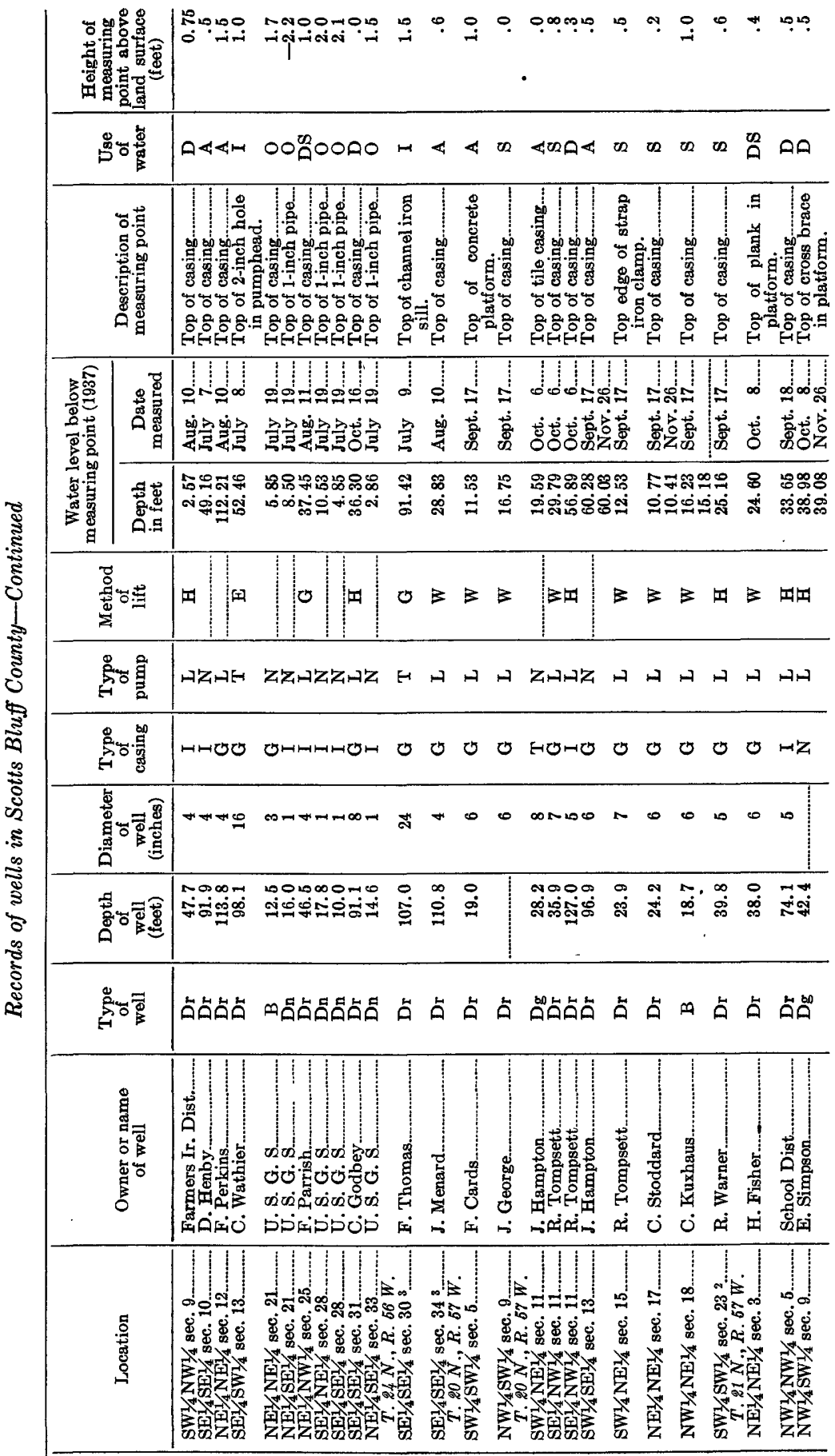

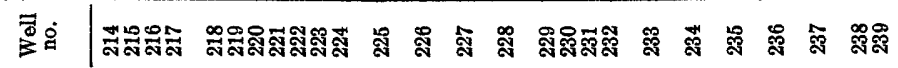




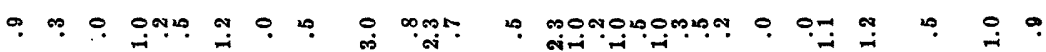

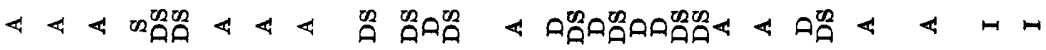

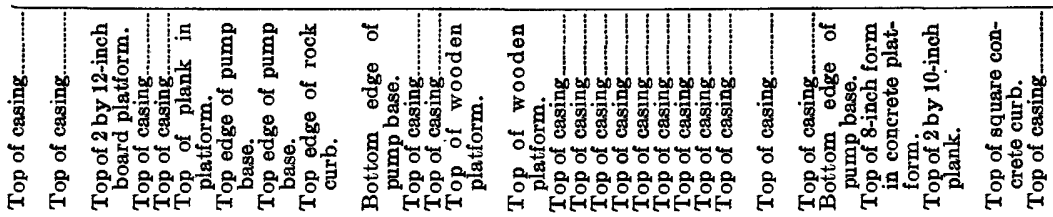

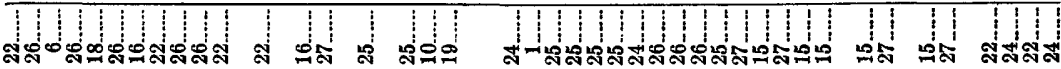

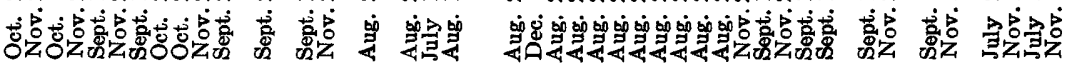

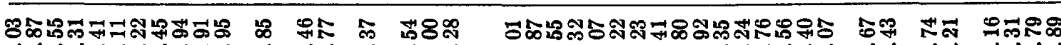

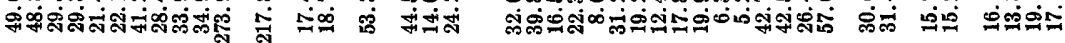

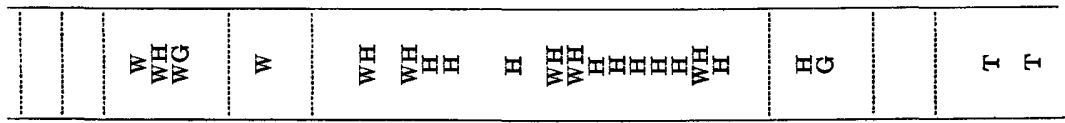

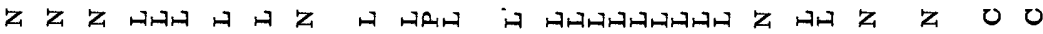

H

\begin{tabular}{|c|c|c|c|c|c|c|c|c|}
\hline$\Rightarrow$ & की & 0 ల & A HOA & ஜ & 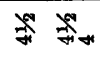 & $\nexists$ & లి & A \\
\hline$=\stackrel{\infty}{\check{\infty}}$ & 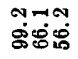 & 莡 & 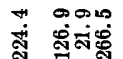 & 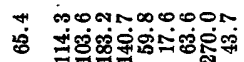 & $\overrightarrow{0}$ & i & ๙ָे & 邑 \\
\hline
\end{tabular}

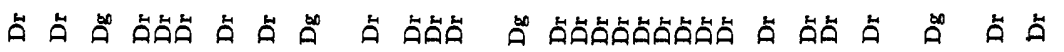

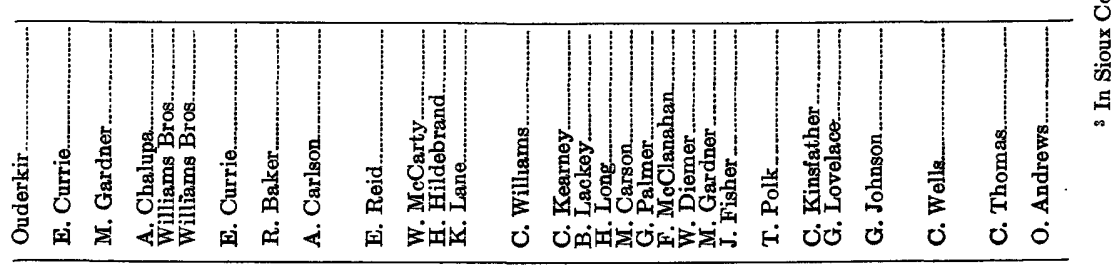

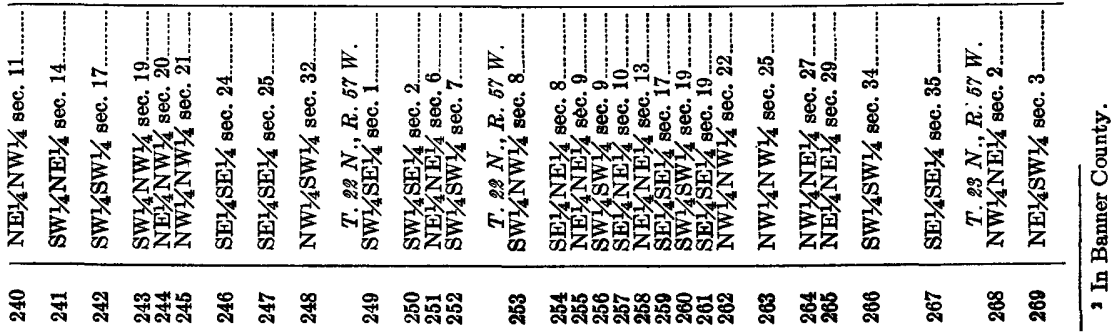




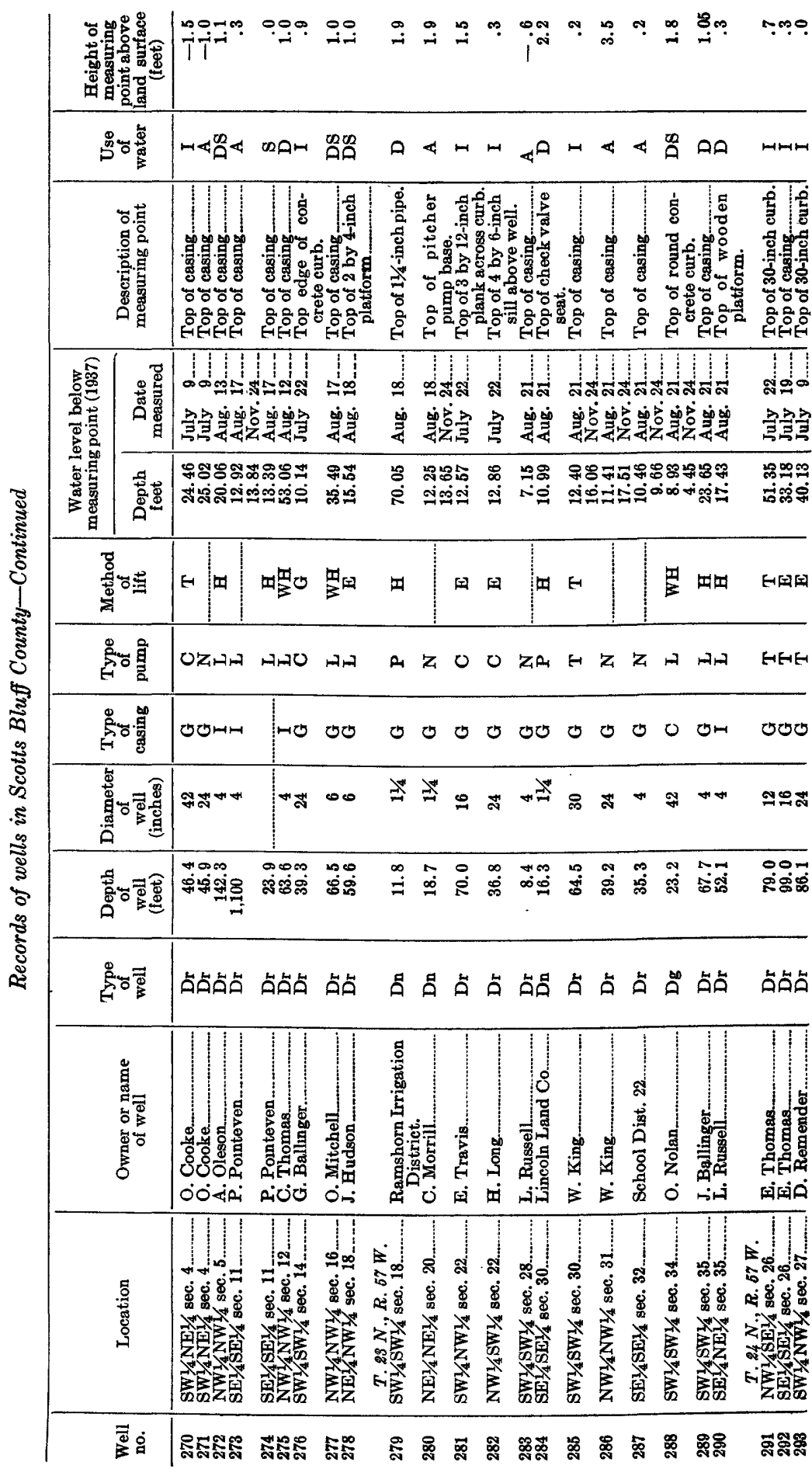




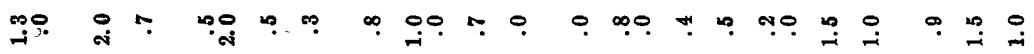

吕

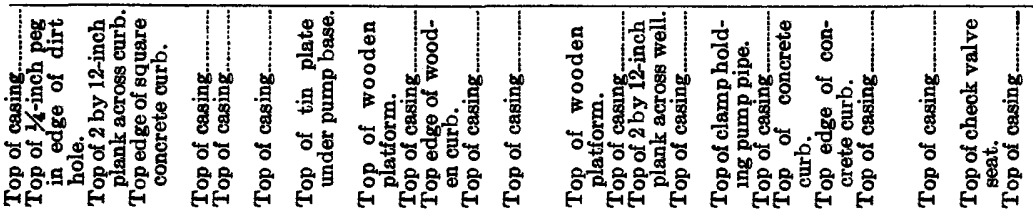

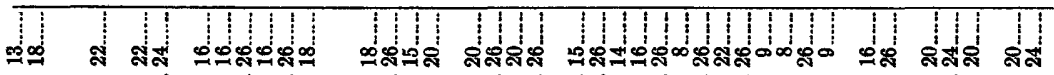

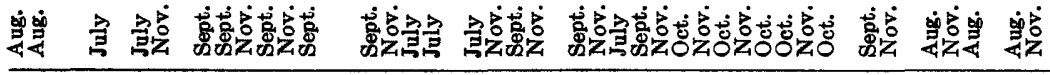

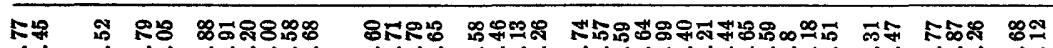

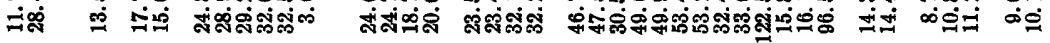

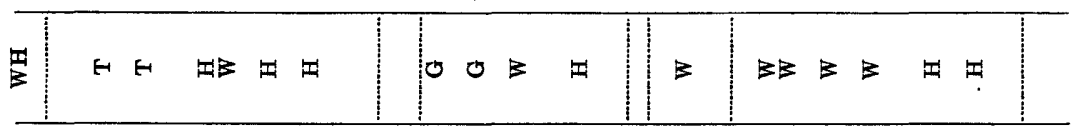

मZ 0 Е МА

\begin{tabular}{|c|c|c|c|c|c|c|c|c|c|c|c|c|c|}
\hline OZ & 00 & On & & 云 吸 & 0 & & $\ddot{M} \omega$ & HO & -0 & $H$ & 0 & 00 & $m$ \\
\hline$\infty$ & 太 & ons 0 & $\infty$ & 艄 & ה & $\Xi$ & 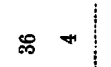 & $\neq$ & $+\infty$ & 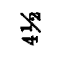 & $\infty$ & $\Rightarrow$ & $\infty$ \\
\hline 番 & 文 : & 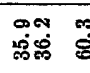 & : & 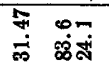 & ஜें & 范 & 氙 & 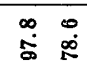 & 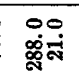 & สิ่ & 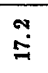 & $\stackrel{\infty}{\infty} \stackrel{?}{=}$ & $\hat{\text { sं }}$ \\
\hline
\end{tabular}

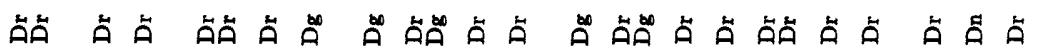

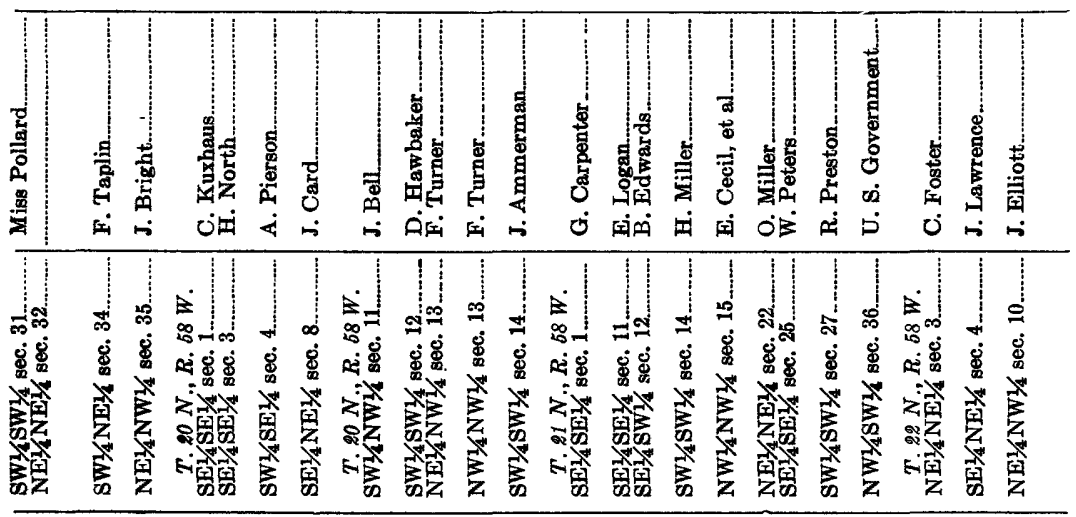

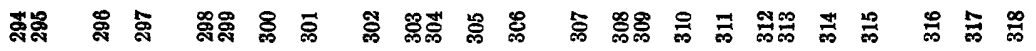




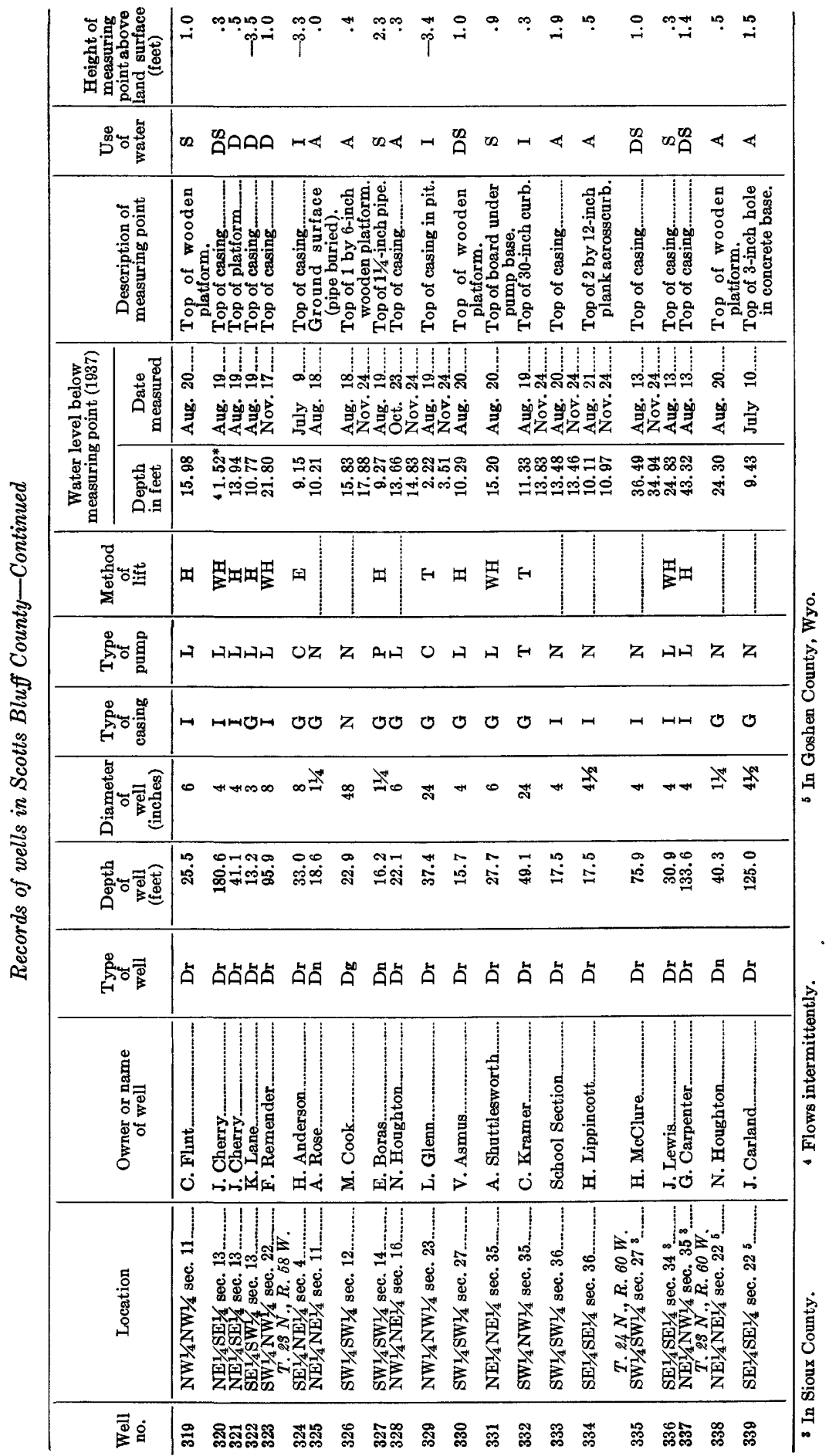




\section{INDEX}

Acknowledgments for aid.
Agriculture in the area.
Arikaree group, Gering formation of
units of.
upper sandstones of
$\quad$ water-bearing properties of
Artesian conditions, occurrence of
Artesian water, depth to
Artifacts, age of
occurrence of

Atmospheric pressure, effect of, on groundwater levels.

55,72

Bentonite, occurrence of. $23-28,41$

Bluffs and pediments, description of

Brule formation, character and distribution of. $66-70$ hydrologic properties of........ 70, 76-77, 83-86, 106 water in, chemical character of................... 127, 128

Bureau of Reclamation, quoted.

Burlington Railroad, water supply for.

Chadron formation, character and distribution of

section of

water-bearing properties of

Climate of the area

Cretaceous system, description of 5-6, 8

Discharge, annual, estimate of. by evapo-transpiration by streams by underflow.

from springs from wells general conditions affecting

Dry Sheep Creek, features of

Dry Spottedtail Creek, features of $53-59, \mathrm{pl} .2$

Evapo-transpiration, discharge by.... 116-117, 118, 126

Field work

Finke creamery, water supply for.

Geography of the area

Geologic history of the area. $17,25-50,52-53$

Geology of the area $53-75$, pls. $2,4,5$

Gering, section near. water supply for.

$111,114,115$

Gering drain, discharge of

Gering formation, character and distribution of 70-72 sections of water-bearing properties of

Great Western Sugar Co., operations by. water supply for.

Ground water, analyses of. chemical character of depth to $116-117,118$ 120-125 125-126

$117,119-120$ 107-116 106

discharge of, annual. by evapo-transpiration.

by streams

by underflow

from springs.

from wells.

general conditions affecting. 128-129 126-131 -89, pls. 4,5 126 $116-117,118$ 120-125 125-126 $117,119-120$ 107-116 106
Ground water, movement of occurrence of.................................................... 75 recharge of __________._._._. 126

Ground-water level, fluctuations of, due to changes in atmospheric pressure._._. 103 fluctuations of, due to changes in flow of North Platte River. 98,100 due to changes of water stored in Lake Minatare. 96-97, pl. 11 due to precipitation .......... 93, 97-98, 99, pl. 10 due to pumping of wells........................ 101-102

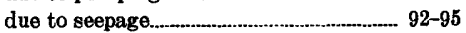
graphs showing ................................. pls. 6-11 method of investigation of.................. $\quad 89$ range of ..........-...-..- 91-92 significance of.___._. 91

Henry, water supply for............................... 114, 116

History, of the area................................ 6-9 of the investigation.................................. 2-4

Ideal Laundry, water supply for...................... 113 Indians, early tribes of._............................... 6-7

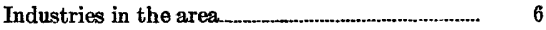
Irrigation, effect of, on ground-water levels..... 91-95, pl. 11

history of 8-9, 13-16 recharge from _................................................... 88 water suitable for........................................ 177 Irrigation canals, location of.___._............... pl. 3

Lake Minatare, effect of, on ground-water levels.......................... 96-97, pl. 11

Lance formation, character and distribution of.. 53-59 sections of _._. water in, chemical character of............... 127, 129 water-bearing properties of _._................. 59, 78 Land forms in the area.................. 17-21, 23-53, pl. 1 Livestock of the area.................................. 6,8 Location and size of the area Lyman, sections near..._._._..........................54, 55 water supply for................................. 114, 115-116

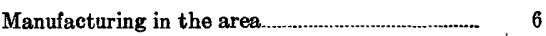

Marketing in the area....................................... 6 Minatare, water supply for..._._............... 111, 114, 115 Mitchell, water supply for._._....................... 114, 115 Mormons, emigration of -............................. 8

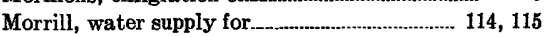

Ninemile Creek, features of.......................... $\quad 19$ Niobrara Valley, features of _._._._................. 20, 21 North Platte River, discharge into......... 120-125, 126 discharge from............................16, 21, 22-23 effect of changes in flow of, on groundwater levels

flood plain of 98,100 streams tributary to.................................. pl. 3 use of, for irrigation................................. 13-16 water in; chemical character of ______.... 127, 129 
North Platte Valley, asymmetry of. walls of.

Page

$10-21$

$17-18,23-50$

Oregon Trail, history of

Pediments 26-27, 41

Permeability, definition of determination of

Platte River, name of. 78

Platte Valley Packing Co, water supply for...... 113

Pleistocene sand and gravel, hydrologic properties of

$76,79-82,106$

Pony Express, operation of.

Population of the area.

Precipitation, effect of, on ground-water level

$91,93,97-98,99$, pl. 10

in the ares

9, 11-12

Pumping, effect of, on ground-water level....... 101-102

Pumpkin Creek Valley, asymmetry of.

Purpose of the investigation.

Quaternary system, description of

Quaternary time, events of.

Recent sand and gravel, hydrologic properties

$$
\text { of. }
$$
$76,79-82$

Recharge, amount and source of. 82,100

Routes of travel, early 88,126

Sand dunes, occurrence of

Scotts Bluff, features of name of section on

Scottsbluff, water supply for

Seepage, effect of, on ground-water levels.

Settlement of the area.

Sheep Creek, features of

Signal Butte, section near

Soils of the area

Specific yield, definition of determination of. $79-80,82,85-86$

Spotted tail Creek, features of

Springs, occurrence of.

Stream processes 117-120

Temperature in the area 21-50

Terraces, age of description of numbering of

Terry Carpenter enterprisee, water supply for...
Tertiary system, description of

Page

Test holes, location of

$$
\text { logs of }
$$

Topography of the area

Towns in the area

Transportation in the area

Underflow, discharge by

Union Pacific Railroad, water supply for

Vegetation in the area

128-129

Water, analyses of

126-131

chemical character of.

107-116

supplies of, source of.

Water-bearing materials, permeability of $\ldots .59,66$,
$70,72,75,78,79-82,83-85,106$

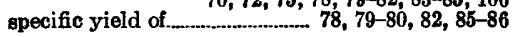

Water table, contour map of, construction of.., 104-105 depth to $86-89$, pls. 4,5

form of 105-106, pl. 3

See also ground-water level.

Well numbers, list of......................................... $\quad 90$

Wells, annual discharge from artesian._....................................... $57,78,89$ farm _.............................................. 3 flowing ............................................ 3

fluctuations in, due to changes in atmospheric pressure......................... 103

due to changes in flow of North Platte

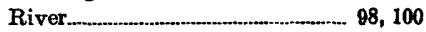

due to changes of water stored in Lake Minatare.

96-97, pl. 11

due to precipitation........ 93, 97-88,99, pl. 10

due to pumping of wells........................... 101-102

due to seepage....................................... 92-95

graphs showing

method of investigation of .................... 89

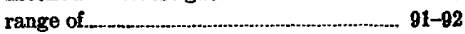

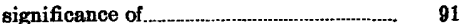

industrial $111-113$

irrigation._._................. 107-109, pl. 3

location of $\ldots \ldots \ldots$

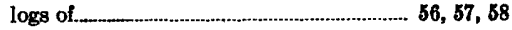

municipal. _._. 113-116

records of $\quad 110,112,114,136-148$

West, travel to

Western Public Service Co., water supply for..111, 113

White River group, age of....................................... character and distribution of $\quad 50-70$

water-bearing properties of ......................... 66, 70

Wildcat Ridge, features of..._............................. 17-18

Wind processes.

113 Winter Creek, features of..................................... 10 



